Florida International University FIU Digital Commons

3-24-2016

\title{
Firm Foundation: Rebuilding the Early Modern State in Lima, Peru after the Earthquake of 1687
}

Judith M. Mansilla

Florida International University, jmans005@fiu.edu

DOI: $10.25148 /$ etd.FIDC000279

Follow this and additional works at: https://digitalcommons.fiu.edu/etd

Part of the Latin American History Commons, Legal Commons, Political History Commons, and the Social History Commons

\section{Recommended Citation}

Mansilla, Judith M., "Firm Foundation: Rebuilding the Early Modern State in Lima, Peru after the Earthquake of 1687" (2016). FIU Electronic Theses and Dissertations. 2443.

https://digitalcommons.fiu.edu/etd/2443 


\title{
FLORIDA INTERNATIONAL UNIVERSITY
}

\author{
Miami, Florida
}

FIRM FOUNDATIONS: REBUILDING THE EARLY MODERN STATE IN

LIMA, PERU AFTER THE EARTHQUAKE OF 1687

A dissertation submitted in partial fulfillment of the

requirements for the degree of

DOCTOR OF PHILOSOPHY

in

HISTORY

by

Judith M. Mansilla

2016 
To: Dean John F. Stack, Jr.

School of International \& Public Affairs

This dissertation, written by Judith M. Mansilla, and entitled Firm Foundations:

Rebuilding the Early Modern State in Lima, Perú after the Earthquake of 1687, having been approved in respect to style and intellectual content, is referred to you for judgment.

We have read this dissertation and recommend that it be approved.

$\begin{array}{r}\text { N. David Cook } \\ \hline \text { Richard Olson } \\ \hline \text { Bianctor Uribe Premo, Major Professor }\end{array}$

Date of Defense: March 24, 2016

The dissertation of Judith M. Mansilla is approved.

Dean John F. Stack, Jr.
School of International \& Public Affairs
Andrés G. Gil
Vice President for Research and Economic
Development and Dean of the
University Graduate School

Florida International University, 2016 
(C) Copyright 2016 by Judith M. Mansilla

All rights reserved 


\section{DEDICATION}

I dedicate this thesis to my husband, my kids, and my mom. Without their patience, support and love, this thesis would have been impossible to complete. 


\section{ACKNOWLEDGMENTS}

This dissertation has been possible thanks to God and the support of several

outstanding individuals. The members of my committee are exceptional academics and

persons. Dr. N. David Cook was the first to believe in my capabilities as a historian and recruited me to join the $\mathrm{PhD}$ history program at FIU. Throughout the program, I have constantly worked to fulfill his high expectations. Dr. Uribe has been very supportive in all my academic initiatives, and I have learned a lot from his academic performance inside and outside the classroom. Dr. Olson has inspired me with his environmental knowledge and insightful view of my city, Lima, and its port. He has helped me to reflect on the similarities of human perceptions about natural disasters during different times in history. My dissertation director, Dr. Bianca Premo has been an assiduous academic and personal mentor along the way. I have no words to thank her for everything she has done to help me achieve this treasured goal. Overall, I am much honored to have such a great dissertation committee.

I also have to thank the many institutions that have economically supported my project in both the research and writing process. The Tinker Research Field Grant of the Tinker Foundation, The History Project Award from Harvard University, The Morris and Anita Broad Research Fellowship from SIPA-FIU, Research Fellowship from the Escuela 
de Estudios Hispanoamericanos, and the Dissertation Evidence Fellowship from

Graduate School-FIU have funded yearly trips to Peru and Spain to collect data at various

libraries and archives from 2011 to 2014. In addition, the Dissertation Year Fellowship

from Graduate School-FIU permitted me to complete the writing and editing of my

dissertation in only a few months.

I also need to thank the many persons that facilitated my research at the archives

such as Yolanda Auqui, Víctor Galvez, Laura Gutiérrez, Fernando López, Celia Soto, and

Melecio Tineo. They have kindly supported my research by guiding me through the

localization and digitalization of primary sources that have been essential to this

dissertation. Special thanks to the personnel at the Archivo Historico de la Municipalidad

Metropolitana de Lima, the Archivo Arzobispal de Lima, the Archivo General de la

Nación, the Archivo Histórico de la Beneficencia Pública de Lima, and the Archivo

Catedralicio de Lima, in Peru, and the Archivo de Indias, and the Biblioteca de Estudios

Hispanoamericanos in Spain.

My former undergraduate professors have contributed to this dissertation with

their suggestions, comments, and interest on my research project. Ada Arrieta, José de la

Puente Brunke, Jesús Cosamalón, Margarita Guerra, Cristina Mazzeo, Liliana Regalado, 
and Miriam Salas have also provided insightful ideas to this dissertation. I would like to specially thank the late Father Jeffrey Klaber who, although is not present to see the realization of this project, also motivated and inspired me to pursue my goals.

I have also many friends who have supported me throughout this journey, either intellectually or emotionally, either by my side or at a distance. Maribel Arrelucea, Diego Chalán, Renzo Honores, and Carol Pasco have constantly provided much needed motivation. Paula de la Cruz, José Carlos De la Puente, and Peter Ferdinando are trustworthy friends that gave a helping hand every time it was necessary. Antony KeaneDawes and Micah Oelze have been attentive listeners to my questions and have challenged me to think critically. Their conversations have made me better academic and person. Andreina Fernandez, Jennifer Sheran, and Grace Solis have been a continuous source of support. I know I can always count on them if necessary. Natalia Del Aguila and Cecilia Sanchez have remained my best friends. Regardless of the distance, they are very dear to me.

Finally, I would like to thank my entire extended family who always cheered me up and motivated me when the going got tough. Thanks to my Papi Cesar for being my father when I needed one and feeling very proud of all my accomplishments. Thanks to 
my cousin José and Grettel for loving my son Jerry and providing constant support throughout all these years. Thanks to Chiva and Max for giving me a hand with Jerry every time I needed it. Thanks to my mom, Melchora Maruja Justo, who has been my hands, feet, and eyes at home. She has traveled with me when necessary or stayed at home to take care of my family. She is so central to this project as the other two Melchores, characters who are part of this dissertation. A special thanks to my beloved husband Eric who has been my main emotional and academic pillar, and the best dad to Jerry and Baby, our miniature schnauzer. Thanks Love for taking care of our babies and being with them during my long absences from home. Thank you for helping me throughout my career, reading my work, taking care of me, and showing me love. Thanks to my son Jerry who, even though he is small, brings great joy to my heart. Thanks to Jerry for loving me, even when he would ask me to stay home and I could not because I had to work; for traveling with me to some of my long research trips without asking his opinion; for not getting home every night before his bedtime; and for even making you sleep in my carrel once. I love you Jerry. Thanks to my dog Baby Bop for gladly welcoming me home every day. She joined me when I moved to the US and has been a loyal reading companion. I love you my baby. Thanks to my little Mochi, my son who is 
on the way, for coming into my family. He has been my closest companion in this final phase of the doctoral program. I apologize to him for the bad meals, lack of naps, and abundant information running through his little brain. Thanks to my daughters, Ariadna and Amaris, who always remain in my mind and heart. They became my first motivation and made mommy strong enough to survive grad school. 
ABSTRACT OF THE DISSERTATION

FIRM FOUNDATIONS: REBUILDING THE EARLY MODERN STATE IN LIMA, PERU AFTER THE EARTHQUAKE OF 1687

\author{
by \\ Judith M. Mansilla \\ Florida International University, 2016 \\ Miami, Florida \\ Professor Bianca Premo, Major Professor
}

One early October morning in 1687, the ground under the large Spanish colonial city of Lima, Peru rumbled. If longstanding historiographical portraits of Spanish government as inefficient and weak were true, the earthquake that was about to shatter Lima should have devastated it beyond repair. The study of the aftermath of this natural disaster reveals that behind the landscape of destruction, the pillars of the colonial state in Lima not only held up but also permitted its rapid recovery after the event. As part of a more recent historiographical trend that reappraises the Spanish decline during the seventeenth century, my dissertation reevaluates the performance of colonial administration in Lima, the capital of the Viceroyalty of Peru. It focuses on deliberate 
changes carried out during the 1680s, when the metropolis implemented a series of fiscal and administrative reforms, whose effects were interrupted but not destroyed by the challenge posed by the earthquake of 1687 .

The use of extensive contemporary archival sources, both official and private, provides a multifaceted vista on the performance of royal agents and colonial subjects responding to the earthquake. A close reading of these sources unveils the rebuilding of the state in various facets: government attempts to impose authority and bring order to the chaos; the patrimonial logic of rules that colonial administrators faced when trying to implement rebuilding projects; colonial subjects' expectations of royal agents and each other; negotiations among authorities and ordinary people over the terms of rebuilding the city; and the importance of inhabitants' understandings of justice, founded in law and custom, to carrying out city reconstruction. 


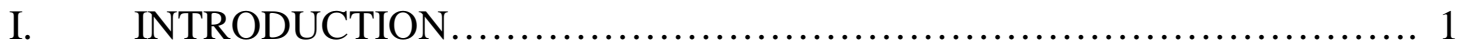

The Black Legend in Spanish History $\ldots . \ldots \ldots \ldots \ldots \ldots \ldots \ldots \ldots \ldots \ldots \ldots \ldots . . \ldots \ldots$

Early Modern State as Historical Subject............................... 12

The Rule of the Early Modern States...................................... 14

The Colonial Spanish State............................................. 20

Methods and Sources................................................. 25

Overview of Chapters............................................... 26

II. CHAPTER 1: THE EPICENTER OF THE SOUTH SEA: THE CITY OF LIMA IN THE LATE SEVENTEENTH CENTURY.......................32

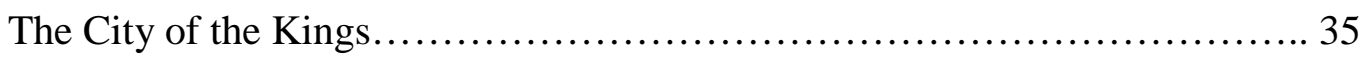

Threats to the Political and Economic Epicenter of the Kingdom............. 43

Lima, the Land of the Tremors......................................... 58

The Archbishop and the Duke......................................... 60

The Duke's Reforms and the Lima Wall.................................67

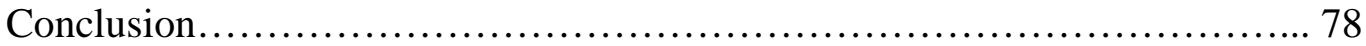

III. CHAPTER 2: CAPACITY, CRISIS MANAGEMENT AND COLONIAL ADMINISTRATION: THE VICEROY AND THE CITY COUNCIL........... 81

The Terrible Night................................................... 92

Tending to Temporal Necessities...................................... 101

Spanish Empire’s Bureaucracy..........................................113

The Reconstruction Projects of the Colonial Administration...................118

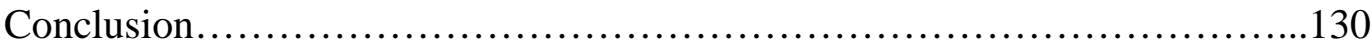

IV. CHAPTER 3: A SEEMINGLY STRONG SURFACE: INTERNAL DIVISIONS AND INTRICACIES OF THE COLONIAL CHURCH...........134

Spiritual Relief: Was the Archbishop?.............................................................139

Temporal Obligations: Rebuilding the House of God........................148

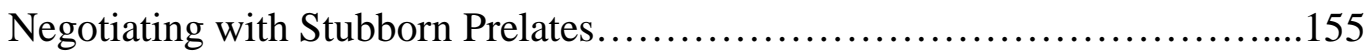

The Head against the Body........................................170 
Conclusion.

V. CHAPTER 4: FROM THE BOTTOM UP: RECONSTRUCTING LIMA

AFTER THE 1687 EARTHQUAKE....................................178

Renters and Owners.................................................. 180

Taking Plans to Court............................................... 189

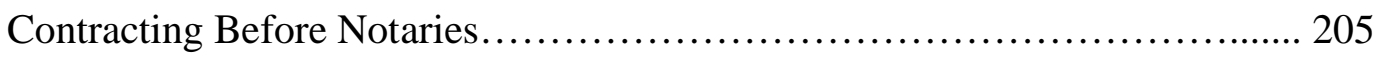

Informal Valid Agreements ........................................... 212

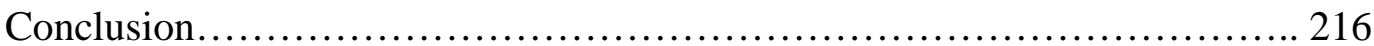

VI. CHAPTER 5: SERVING THE KING: CONTROL AND ADMINISTRATION OF THE ROYAL TREASURY OF LIMA IN THE LATE SEVENTEENTH CENTURY ........................................................220

The Economic and Political Black Legend of Spain...................... 223

The General Visita to the Cajas Reales....................................225

The Duke's Fiscal Reforms.............................................241

The Danger of Living on the King's Peso..................................244

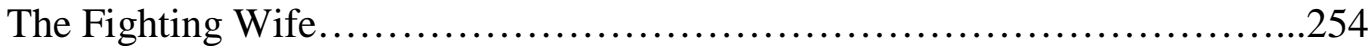

Conclusion.......................................................... 260

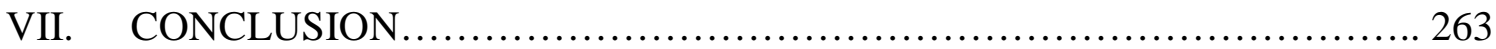

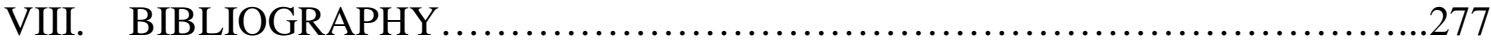

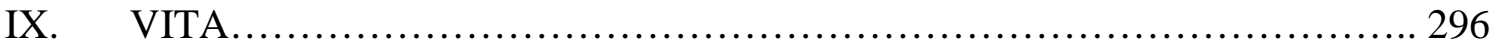




\section{LIST OF FIGURES}

FIGURE

PAGE

1. Lima, capital of the Viceroyalty of Perú....................................33

2. Plaza Mayor of Lima of the kingdoms of Peru.............................. 40

3. Fortifications under (A) Principe de Esquilache and (B) Marquis of Guadalcazar.....48

4. The Marquis of Mancera.................................................. 52

5. Fortifications made by (C) Count of Chinchón, and (D) Count of Mancera...........54

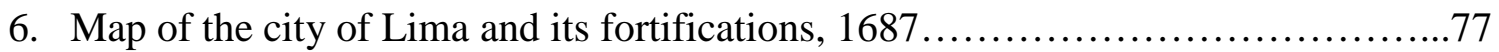

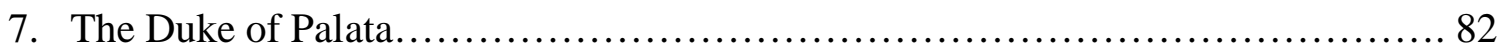

8. Indian settlements, Pitipiti and Quilcay, destroyed by the earthquake.............. 95

9. Lima’s main buildings and plazas......................................96

10. Location of lands requested as propios by the city council.....................127

11. Location of Late..................................................... 145

12. Map of principal religious buildings in Lima.................................150

13. The Archbishop Melchor de Liñán y Cisneros...............................171

14. Approximate location of some of the private properties.......................195

15. The Count of Castellar..................................................232 


\section{ABBREVIATIONS}

AAL Archivo Arzobispal de Lima

ACL Archivo Catedralicio de Lima

AGI Archivo General de Indias (SPAIN)

AGN Archivo General de la Nación (PERU)

AHBPL Archivo Histórico de la Beneficencia Pública de Lima

AHMML Archivo Histórico de la Municipalidad Metropolitana de Lima

BNM Biblioteca Nacional de Madrid 


\section{INTRODUCTION}

One early October morning in 1687, the ground under the large Spanish colonial city of Lima, Peru rumbled. If longstanding historiographical portraits of Spanish government as inefficient and weak were true, the earthquake that was about to crash into Lima should have devastated it beyond repair. The study of the aftermath of this natural disaster reveals the rapid response of the colonial administration in coping with the needs of the people, and the active participation of both Lima's residents and royal officers in the reconstruction of the city. Behind the landscape of destruction, the pillars of the colonial state in Lima not only withstood the destruction produced by the quake but also permitted its rapid recovery.

This outcome contrasts with the traditional image of weakness and incapacity to rule that scholars conventionally have painted in studies of Hapsburg Spain. The study of seventeenth-century Spanish Hapsburg government, specifically, possesses a long tradition of economic, political, and, in the last two centuries, historical writings influenced by the "Black Legend." Though it originated in the sixteenth century, the Black Legend-- a set of negative and pejorative portrayals of the Spanish people, institutions, and activities-- still pervades historical representations of Spain and its 
empire. In particular, in the seventeenth century the Black Legend served to support contemporary critics of Spain who emphasized its imperial downfall. Philosophers, politicians, economists and, much later, historians continued to propagate the idea that Spain's governance of its territories was riddled with ineptitude, decadence, and lack of control mechanisms.

As part of a more recent historiographical trend that reappraises the Spanish decline during the seventeenth century, my dissertation reevaluates the performance of Spanish colonial administration in Lima, the capital of the viceroyalty of Peru. It focuses on deliberate changes carried out during the 1680s. During this decade, the metropolis implemented a series of fiscal and administrative reforms, whose effects were interrupted by a strong natural event, the Earthquake of 1687 . A comprehensive study of the administration of the Viceroy Duke of Palata, whose tenure spanned most of this decade, is essential to understanding these changes because he promoted and carried out innovative crown policies, as well as handling the material, political, and social effects of the quake.

The main elements of the study cover the post-disaster period in Lima, especially royal officers' response to the increasing demands of a population in crisis. Using social, 
cultural, political, economic, legal, and environmental historical approaches, this work reevaluates the interplay between institutions and people as they rebuilt Lima and, in this process, reconstituted an early modern state. The creative measures and approaches implemented during the reconstruction period reveal the effectiveness of Spanish rule in imposing a widespread and common legal framework used by colonial subjects.

The proactive and expedient response of the colonial administration in Lima, facing one of the most damaging natural disasters that hit the city and indeed the empire, demonstrates its capacity of crisis management. The period of reconstruction brought about a series of challenges for the royal agents who attempted to implement various rebuilding projects. Secular officials successfully managed to work around a depleted royal treasury and the political opposition of the main religious authorities in order to rebuild the city and its administration. Their success in carrying out these projects further undermines the depiction of imperial Spain as deficient in authority and control.

Through the examination of complex sets of practices and rules that governed the interactions between colonial administrators and subjects, the post-quake reconstruction period also reveals the everyday creation of an early modern state. In order to rebuild property destroyed by the quake, a highly diverse colonial population adopted, adapted, 
and reproduced the forms and mechanism of the Spanish legal system, an ambit of social and political life that has long been framed as central to state formation.

The final part of this study examines the flexibility and creativity of Spanish colonial administration in the New World. A close review of a royal audit of Lima's treasury and its administrators, well underway prior to the earthquake, demonstrates how the crown maintained mechanisms to control and bring greater fiscal order to Lima, as well as to enhance the performance of royal administrators. The secular government's response to the Earthquake of 1678 was no mere anomaly; instead, it encapsulated and indeed galvanized a process of reform and fortification of the royal state already in process. Ultimately, this examination, and the dissertation as a whole, demonstrates how a state—-for so long deemed inefficient and weak-- could be strong enough to withstand the turmoil of the quake.

\section{The Black Legend in Spanish History}

The concept of seventeenth-century decline is still ubiquitous among scholars writing about Spain and its colonial domains. Traditional studies use this notion to describe

features of governance such as decentralization, negotiation, consensus and 
patrimonialism, which in turn explain Spain's weakness and its inability to develop into a modern state comparable to other European national powers like England and France. ${ }^{1}$

This unfavorable portrait is related to the Black Legend, developed by Spain's political rivals to attack the missionary Catholic character of the Spanish colonization and the excesses committed in name of God. ${ }^{2}$ Nonetheless, it later served to support Spain's own discourses of political and economic backwardness. ${ }^{3}$ In the early seventeenth century, Spanish Hapsburg royal advisers known as arbitristas, who critiqued and suggested solutions to the king's problems, were the first to use the term "decline" to describe the period of economic and political downturn Spain was entering. ${ }^{4}$ They criticized bad

\footnotetext{
${ }^{1}$ Schmidt-Nowara, Christopher and John M. Nieto-Phillips, Interpreting Spanish Colonialism: Empire, Nations and Legends (Albuquerque: University of New Mexico Press, 2005), 9.

${ }^{2}$ William s. Maltby, The Black Legend in England: The development of anti-Spanish sentiment, 1558 1660. (Durham: Duke University Press, 1971), 135, 136; Joseph Sanchez, The Spanish Black Legend: Origins of Anti-Hispanic stereotypes (Albuquerque: National Park Service, Spanish Colonial Research Center, 1990), 4-8.

${ }^{3}$ Jeremy Adelman, “Introduction: The Problem of Persistence in Latin American History," in Colonial Legacies: The Problem of Persistence in Latin America History, edited by Jeremy Adelman (New York: Routledge, 1999), 3, 4.

${ }^{4}$ Helen Rawlings, The Debate on the Decline of Spain (Manchester: Manchester University Press, 2012), $31,34$.
} 
government and economic decay, calling for mercantilist and political changes in order to reverse Spain to its previous political and economic grandeur.

After dynastic change in Spain in the early 1700s from Hapsburg to Bourbon rule, ministers of the new royal house and other European intellectuals used the notion of decline to refer to Spain's ostensibly retrograde condition in comparison to other European powers. These writers and policymakers recognized that the idea of Hapsburg decadence originated from intolerant and ignorant characteristics attributed to Spain by the "Black Legend." 5 Yet the concept of decline did not disappear. This was because in order to address these deficiencies, Bourbon ministers attempted to implement a series of enlightened reforms based on a combination of foreign examples and traditional Spanish ideas. ${ }^{6}$ These politicians deliberately used the concept of Hapsburg decline to justify their reforms, and, similar to foreign politicians, had a political interest in exaggerating the contrast between the Hapsburgs and the new governing dynasty. ${ }^{7}$

\footnotetext{
${ }^{5}$ Ibid, 50.

${ }^{6}$ Gabriele Paquette, Enlightenment, Governance, and Reform in Spain and its empire (Cambridge: Palgrave Macmillan, 2011), 31.

${ }^{7}$ Jaime Vinces Vives, An Economic History of Spain, translated by Frances M. López - Morillas (Princeton: Princeton University Press, 1969), 398, 411; Ruth MacKay, 'Lazy, Improvident People:' Myth
} 
Up to the beginning of the twentieth century, Spanish and foreign intellectuals used the concept of decline to explain Spain's failure to retain its colonial domains and its transformation into a second-class European nation. ${ }^{8}$ By then, scholars emphasized Spain’s lack of a systematized state structure, meaning a lack of central control and weak infrastructural power which permitted other European nations to lead the path into modernity. Hapsburg Spain was, in contrast to these modern states, a patrimonial state that resorted to negotiation and coercion in order to impose control and authority because it lacked the institutional means to force its subjects into compliance.

The professionalization of history, the aperture of the archives in Spain after the end of the Franco era, and the ascendancy of the Annales School of social history decades later created new tools and approaches to study Spain's imperial past. With new developments in the field, scholars began to recognize that Spain's crisis had been exaggerated; yet, they still agreed that there was a decline during the seventeenth century as evidenced by its poor economy, depopulation, and poor administration. ${ }^{9}$

and Reality in the Writing of Spanish History (Ithaca: Cornell University Press, 2006); David Ringrose, Spain, Europe, and the 'Spanish Miracle,' 1700-1900 (Cambridge: Cambridge University Press, 1996).

${ }^{8}$ Rawlings, The Debate on the Decline of Spain, 92.

${ }^{9}$ Earl Hamilton, “Revisions in Economic History: VIII. The Decline of Spain,” The Economic History Review 8, No. 2 (May, 1938), 168-179, associates the economic decline of Spain to the character of its 
Starting in the 1960s, the debate over the Spanish decline resurfaced in Past and

Present, a journal that rapidly became a space of intellectual interchange among Englishspeaking academics who began to identify various attempts of recovery and reform during

the last Hapsburg administration. ${ }^{10}$ Scholars discovered the existence of a general crisis throughout Europe during the seventeenth century, and signaled that many of the state characteristics which had justified previous authors' portrayals of Spain as weak and its rulers as inept were also present in other regions of Europe. ${ }^{11}$

rulers, which he considers were in progressive deterioration in the seventeenth century; War and prices in Spain, 1651 - 1800 (Cambridge: Harvard University Press, 1947), argues the recovery and progress of the country began under the first of the Bourbons, who he considers were more competent rulers than their predecessors; Jaime Carrera Pujal, Historia de la Economía Española, vol. 2 (Barcelona: Bosch Casa Editorial, 1944), contrasts the image of decadence for the seventeenth-century with that of improvement for the next century. On one hand, he depicts the period of Charles II's regime as a time of decline reflected in the inefficacy of the government and economic crisis. On the other hand, he proposes the Bourbon rulers began to introduce reforms as soon as the Succession War ended. Vinces Vives, An Economic History of Spain, 385, 411, reinforces the idea that the Hapsburg Spain and the Bourbon regime were regimes of opposite natures. He argues that the economic recession that took place in the New World by the second half of the seventeenth century accentuated the decay Spain experimented in the same century. He argues for French influence in Spanish culture, politics, economy, and technology during the Bourbon regime contributed to the recovery of Spain from the Hapsburg's failures.

${ }^{10}$ Rawlings, The Debate on the Decline of Spain, 132, 133.

${ }^{11}$ John Elliot, “The Decline of Spain,” Past \& Present 20 (Nov., 1961), 52-75, states that great part of the seventeenth century appears as a time of commercial contraction and demographic stagnation for Europe in general, yet differed from region to region. He also predicted that future studies would confirm the ineptness of Spain in that period. Geoffrey Parker and Lesley Smith, "Introduction," in The General Crisis 
These academics also argued that the Hapsburg administration attempted and implemented various reforms that slightly improved the condition of the empire, refroms that laid the bases for the vaunted Bourbon Reforms of the next century. ${ }^{12}$ Historians found that even studies of Spain that had been conducted during the early eighteenth century underlined the various political and economic reform measures introduced during the last Hapsburg ruler, King Charles II. The authors argued that scholarly emphasis on the regime of Bourbon King Charles III and his late eighteenth-century policies have obscured the multiple attempts of transformation initiated during the last Hapsburg administration and continued by the early Bourbon monarchs. ${ }^{13}$

of the Seventeenth Century, edited by Geoffrey Parker and Lesley M. Smith (Boston: Routledge \& Kegan Paul, 1978), 1 -32; Global Crisis. War, Climate Change \& Catastrophe in the Seventeenth Century (New Haven: Yale University Press, 2013).

${ }^{12}$ John Elliot, Imperial Spain, 1492 - 1716 (New York: New American Library, 1963), explains that Castile and other regions began to show signs of recovery by the 1680s. He identifies as the promoters of these improvements to the Count of Oropesa, prime minister from 1685 to 1691, whose reforms created the precedent for future reformative programs under the Bourbon dynasty. John Lynch, Spain under the Habsburgs, vol. 2 (Oxford: Basil Blackwell, 1969), recognizes Spanish administration and economy began to present signs of improvement, between 1680 and 1691, thanks to the labor of the Prime ministers the Duke of Medinaceli and the Count of Oropesa. Spain did not pass suddenly from obscurantism to enlightenment with the transference of dynasty, but the last Hapsburg administration left the foundation for the next dynastic rule.

${ }^{13}$ John Lynch, Bourbon Spain, 1700 - 1808 (Oxford: Basil Blackwell, 1989), explores the transformations in Spain and its colonies resulting from the dynastic transference during the eighteenth century. He states 
By the late twentieth century, scholarly reappraisals of the seventeenth-century Spanish crisis discovered that negotiation, decentralization and flexibility were better or more appropriate terms to describe the state-society relationship in Hapsburg Spain than were "crisis” and "decadence.” Contrary to previous historical analyses, scholars did not interpret these characteristics as conveying obsolescence or signs of failure but as vital features that permitted the development and permanence of the empire, providing opportunities for its inhabitants and administrators alike. ${ }^{14}$ Studies within this new

that there was a period of recovery, which started in the 1680s under Hapsburg rule, and lasted until the 1740s. Adrian Pearce, The Origins of Bourbon Reform in Spanish South America, 1700-1763 (Hampshire: Palgrave Macmillan, 2014), 2,11, affirms that the period between the mid-seventeenth century and the Enlightenment absolutism heyday of Charles III remained scarcely explored. The Late-Bourbon reforms had overshadowed early waves of reform that the administration, both peninsular and colonial, consciously promoted in early decades. Luis Ribot, El Arte de Gobernar: Estudios sobre la España de los Austrias (Madrid: Alianza Editorial, 2006), demonstrates that during the government of Charles II, the last Hapsburg king on the Spanish throne, the monarchy attempted and implemented various administrative innovations. Allan Kuethe and Lowell Blaisdell, "French influence and the Origins of the Bourbon Colonial Reorganization,” Hispanic American Historical Review 71, No. 3 (Aug., 1991): 579-607, affirm that the first Bourbon monarchs, Phillip V and Ferdinand VI, did not introduce great innovations in the empire, instead they mainly preserved the old system with small repairs. Geoffrey Walker, Spanish Politics and Imperial Trade, 1700 - 1789 (Bloomington, Indiana University Press, 1979), states that the Spanish administrators and merchants were effectively conscious of the terrible condition of the mercantile system since the late seventeenth century. Attempts of reforms began in 1679, even before the dynastic transference.

${ }^{14}$ MacKay, "Lazy, Improvident People”, examines the common belief that Spaniards disrespected labor and mechanical activities, and viewed workers as vile people. She argues that this notion is distant from how contemporaries regarded labor and workers in the sixteenth and seventeenth centuries. She 
historiographical trend argue that, even when eighteenth-century reformers were behind the construction of many of these negative depictions of Hapsburg Spain, scholars' insistence on comparing Spain to other, purportedly "modern” European nations such as England and France serves only to reinforce the notion of Spanish decline. ${ }^{15}$ In other words, the political interests of both historical actors and modern historians influenced the construction of a biased analyses and critical representation of Hapsburg Spain.

demonstrates that commoners in Castile considered themselves that they were essential because of their work to their community and the common good. She proposes the disrespect for labor and workers was an essentially eighteenth-century myth that Bourbon reformers crafted in order to justify the existence of an irrational labor force that needed transformation, and modern authors later reinforced as real; Regina Grafe, Distant Tyranny: Markets, Power, and Backwardness in Spain, 1650 - 1800 (Princeton: Princeton University Press, 2012), xvi, argues that even though Spanish subjects were not equal in the old regime, they had access to courts and learned to exploit them in their benefit.

She states that the idea of Spanish distinctiveness is well rooted in the Western historiography since the sixteenth century, when Northern European authors underlined with suspiciousness Spain's ethnic and religious heterogeneity. This concept of distinctiveness turned into lack of civilization in the eighteenth century when Spain was considered unable to adopt enlightened features.

${ }^{15}$ David R. Ringrose, Spain, Europe, and the 'Spanish miracle,' 14, 15; and Xavier Gil Pujol, "Pensamiento politico español y europeo en la Edad Moderna. Reflexiones sobre su estudio en una época post-whig," in Campo y campesinos en la España Moderna. Culturas Políticas en el Mundo Hispano, edited by María José Pérez Álvarez and Alfredo Martín García, (León, Spain: Fundación Española de Historia Moderna, 2012), 208, state scholars' insistence to compare Spain with other North-European nations, which fit and support better the teleological history of the West, has underlined the notion of Spanish decline. Grafe, Distant Tyranny, x, xi, shows the idea of Spain's distinctiveness turned into uncivilized in the eighteenth century, when it was perceived as unable to adapt to the new enlightened ideas. 
Despite the progress on the Spanish decline debate, which remains inconclusive, scholars realize that the notion of Spanish degeneracy is deeply rooted in people's historical imagination, even among some in the academic realm. While recent historiography is beginning to finally uproot the assumption of decline in Hapsburg Spain, we still need to better understand not only what Hapsburg Spain was not but also what it was. This ultimately entails reviewing the way the Spanish state governed within its historical context.

\section{Early Modern State as Historical Subject}

Like the economy of the Hapsburg empire, scholars have cast doubts on the solidity or efficiency of the Spanish American colonial state by comparing it to contemporary models of the modern state. In The King's Living Image, historian Alejandro Cañeque presents the state as a problematic concept that many scholars have used indiscriminately, without questioning its existence or appropriateness, to describe the apparatus of governance Spain implemented in the New World. Analysis of the colonial state has merely focused on evaluating if it was “weak” or "strong." 16 Scholars' insistence on examining Spain in the early modern period according to the current definitions of nation-state

\footnotetext{
${ }^{16}$ Alejandro Cañeque, The King's Living Image. The Culture and Politics of Viceregal Power in Colonial Mexico (New York: Routledge, 2004), 4,5.
} 
formation and market building, which are considered the signal milestones of the current Western model of progress, have underlined Spain's lack of central power and incapacity to impose rule as features of weakness. ${ }^{17}$

Using these theoretical parameters or models to analyze the colonial state, the Spanish political system in the New World looks far from modern. Over a half century ago, John Phelan asserted that Spanish colonial bureaucrats had ambiguous objectives and conflicting standards regarding the implementation of law. The same body of legal codes allowed bureaucrats to postpone or evade the observance of norms issued by the central government. ${ }^{18}$ In the following decades, scholars began to identify other features of the Hapsburg system, such as consensus, negotiation, overlapping jurisdictions, and patrimonialism, without judging them as indicators of "weakness" or "strength" according to an imagined modern metric.

\footnotetext{
${ }^{17}$ Grafe, Distant Tyranny, x, xi.

${ }^{18}$ John Phelan, “Authority and Flexibility in the Spanish Imperial Bureaucracy,” Administrative Science Quarterly 5, No. 1 (Jun., 1960), 63, 64.
} 
These studies, for instance, demonstrate that the stability of the government relied on consensus among various corporative interests rather than an absolute monarchy. ${ }^{19}$ Negotiation permitted the intromission of local elite's interest in the development and implementation of colonial politics, which resulted in a compromise state rather than an absolutist one. ${ }^{20}$ Yet the observation of these features and the functioning of early modern governance has revealed the stubbornness of the historical category of "state." According to some historians, the lack of absolute royal power, the existence of overlapping jurisdictions, and the constant negotiation between the administration and the colonial subjects seem indicate not that we develop more capacious definitions of the "state" but instead that no state existed under Hapsburg rule.

\section{The Rule of the Early Modern States}

But perhaps the "state" lies in the eye of the beholder. French postmodern historian Michel Foucault recognized the existence of a different form of rule, or "governmentality," up to the seventeenth century. He defined this kind of government as the proper manner of

\footnotetext{
${ }^{19}$ Henry Kamen, Spain in the Later Seventeenth Century, 1665 - 1700 (London: Longman, 1980), 17, 23, 25.

${ }^{20}$ John Lynch, “The Institutional Framework of Colonial Spanish America,” Journal of Latin American Studies, 24, Quincentenary Supplement: The Colonial and Post Colonial Experience. Five Centuries of Spanish and Portuguese America (1992): 74
} 
managing things to lead not so much to benefit the common good but rather to an end “convenient” (befitting or appropriate; in Spanish, “conveniente”) for each of the things or groups that are to be governed. ${ }^{21}$ Foucault reveals that there are many ways to conceive political rule beyond the parameters of the so-called modern state. Indeed, his reminder is a helpful one because it encourages us to view Spain within the broader range of modes of governing that existed in early modern Europe.

When compared to paradigms of early development and modernization derived from other European nations, such as France and England, Spain’s political system and form of rule seem more similar than different. Describing the process of state-formation in England during the late sixteenth and seventeenth centuries, Michael Braddick defines the early modern state as a political system whose local officers were part of a territorially, centrally coordinated bureaucratic network, backed by a legitimate force that emanated from the ruler. Public offices were in and of themselves institutions of the state. When an officeholder occupied a position, he acquired the authority to exercise legitimate force to secure compliance from the subjects he ruled. Still, even when royal agents received

\footnotetext{
${ }^{21}$ Michel Foucault, “Governmentality,” in The Foucault effect. Studies in Governmentality with two lectures by and interview with Michael Foucault edited by Graham Burchell, Colin Gordon, and Peter Miller (Chicago: The University of Chicago Press, 1991), 95.
} 
legitimation from the monarch, they were also empowered by social authority. Thus they had to live by the standards of their communities as well as those of their superiors. ${ }^{22}$ Within this definition of state, the seemingly contradictory performance of many royal officers who abstained from implementing royal or top-down laws that they considered unsuitable for local conditions make sense. Their legitimacy rested on balancing the interests of the king and the subjects.

In the case of France, William Beik demonstrates that the rise of absolutism was not the result of a repressive system that reduced all its subjects under control, attracting nobles to the court while imposing greater burdens on the peasantry. He argues that the centralization of the political apparatus of Louis XIV became possible because of the allegiance of provincial elites to the monarchy's authority, which resulted from the king's increasing protection of elites' interests, rather than repression. Provincial elites became more willing to cooperate with the central government. ${ }^{23}$ The government of Louis XIV built its strength not by eradicating clientage and venality, understood as the king's

\footnotetext{
${ }^{22}$ Michael Braddick, State Formation in Early Modern England, c. 1550-1700 (Cambridge: Cambridge University Press, 2000), 9.

${ }^{23}$ William Beik, Absolutism and Society in Seventeenth-Century France: State power and provincial aristocracy in Languedoc (New York: Cambridge University Press, 1985), 31.
} 
inability to control society, but rather through networks of personal and institutional ties along lines of authority. ${ }^{24}$

These studies show that characteristics such as decentralization, venality, clientage, negotiation, and “conveniencia" are not proof of early modern states' weakness or inferiority, yet they had the effect of “demodernizing” seventeenth-century governments. England, with its early constitutional forms, and France, with its development of a central state, eclipsed Hapsburg Spain’s “non-modern” features and stigmatized its political system.

Recently, historians seeking to show that Hapsburg Spain’s political system was not exceptional employ the concepts of “composite” and "polycentric" monarchies to describe the seemingly complex Spanish system of governance. British historian John Elliot defines "composited monarchies” as a myriad of various territorial or jurisdictional units, whose elites maintained legal and self-government privileges through their loyalty to the monarch, who maintained patronage to reward and keep such loyalty. ${ }^{25}$ Even though

${ }^{24}$ Ibid, 13-15.

${ }^{25}$ John Elliot, Spain, Europe \& the Wider World, 1500-1800 (New Haven: Yale University Press, 2009), 52,53 , explains that these composite monarchies resulted from two possible ways of unification. The "accessory” union was when a territory, united to another kingdom or province, became regarded juridically as part of such kingdom or province, and its inhabitants adopted the same rights and laws of 
it was not unique, the so-called Spanish Hapsburg Empire represented the best example of composited monarchies. This system was practical for its time because it created both stability and resilience for the extensive Spanish monarchy, where the diverse legal status of its jurisdictional units, the long distances between its colonial provinces and the court, and the patrimonial condition of its ruling dynasty made it necessary to resort to negotiation, “conveniencia," and decentralization.

More recently, building on the concept of "composite" monarchies, some scholars propose the concept of "polycentric" monarchies. They argue that, rather than relationships between the center and its periphery, there were various interlinked centers that actively participated in the making of politics in early modern societies. This model also recognizes the mobility of the political structures, and the need of negotiation, clientage, and patrimonialism, which provided solidity and malleability to the multiterritorial monarchies. ${ }^{26}$

those in the kingdom or province's jurisdiction. The Indies represented the best example of this type of union. The second kind of union was that called "aeque principaliter," which referred to the union of one kingdom to another, maintaining its distinctiveness, identity, and laws. The annexation of Aragón, Valencia, or Catalonia to Castile is an example of aeque pincipaliter.

${ }^{26}$ Pedro Cardim, Tamar Herzog, José Javier Ruiz Ibáñez and Gaetano Sabatini, “Introduction,” Polycentric Monarchies: How Did Early Modern Spain and Portugal Achieve a Global Hegemony? edited by Pedro 
The Spanish colonies of the New World, called the "Indies," represented, according this model, a center among others within the Spanish "polycentric” monarchy. Even though the Indies was legally an "accessory” province to Castile, its extension produced regional subdivisions, where Mexico City and Lima were two centers called "viceregal" capitals. ${ }^{27}$ Despite their prominent position among other cities in the Indies and their increasing contribution to the entire monarchy, they were centers in the periphery. The model of "composited" monarchies seems appropriate for understanding their place in the imperial structure of Spanish Hapsburg governance because colonial officeholders ultimately sought legitimation of their political decisions before the monarch. Nonetheless, they were careful that their behavior remained within the limits of what locals considered a good royal agent. Otherwise, they could lose authority among colonies subjects and ultimately the power the king had bestowed on them. In other words, the political privileges and limits

Cardim, Tamar Herzog, José Javier Ruiz Ibáñez and Gaetano Sabatini (Brighton, UK: Sussex Academic Press, 2012), 3, 4.

${ }^{27}$ Rafael García Pérez, “Revisiting the America’s Colonial Status under the Spanish Monarchy,” in New Horizons in Spanish Colonial Law: Contributions to Transnational Early Modern Legal History, edited by Thomas Duve and Heikki Pihlajamäki (Frankfurt: Max Planck Institute for European Legal History, 2015), 47, 48. 
of the political elite at provincial centers, even those at the viceregal courts, were defined by their relationship to the main center and the king's court.

\section{The Colonial Spanish State}

The colonial state in the Spanish Indies was patrimonial in nature. The relationship between the ruler and his subjects was defined both by law and practice, which were sometimes contradictory. ${ }^{28}$ Authority in the colonial state derived from the ruler's personal and private rights. Even the legitimacy of law and bureaucracy proceeded from the fact that they were considered manifestations of the ruler's personal power. ${ }^{29}$ Consensus between the metropolis and the colonies was built on experience and had permitted the permanence of the empire by balancing loyalty to the crown and local interest. ${ }^{30}$

Overlapping jurisdictions, patrimonialism, and negotiation between the central government and colonial subjects are not, in the end, characteristics of incapacity and

\footnotetext{
${ }^{28}$ Miguel Costa, "Patronage and Bribery in Sixteenth Century: The Government of Viceroy Conde del Villar and the Visita of Licentiate Alonso Fernandez de Bonilla” (PhD Diss., Florida International University, 2005), 21, 22.

${ }^{29}$ Ibid, 27, explains the traditional political systems is where "society follows an order based on traditional authority and obedience to personal authority.” The legal patrimonial state is established by a society based on the obedience to a legal system. In the patrimonial state, a sub-category of the traditional order, the ruler “organizes his political power over extra-patrimonial areas and political subjects.”

${ }^{30}$ Lynch, Bourbon Spain, 351.
} 
failure. They were necessary elements for reaching the goal held by every early modern state-- to provide to each part of the political body what was most fitting, or "conveniente," according to their socio-political condition.

The repetition of practices of negotiation and legitimation, which engaged both royal officers and colonial subjects, reveals the existence of a set of patterns that became rooted in colonial society. According to Braddick, royal agents obtained social authority through legitimating languages or discourses that subjects understood and accepted as valid. Even when officers' actions appeared to oppose to the king's will, they justified their actions by appealing to the legitimating ideas at their disposal, such as the fulfillment of a wider range of locals' expectations, reward for their loyalty, or the maintenance of the customary political order. ${ }^{31}$

This set of legitimizing ideas, valid for both the ruler and the ruled, constituted an ethos or common framework that gave unity and coherence to the political body, regardless of its heterogeneous compositions and particularities. ${ }^{32}$ The development of this common ethos was not monopolized or solely regulated by the state, although it was

\footnotetext{
${ }^{31}$ Braddick, State Formation in Early Modern England, 7.

${ }^{32}$ Phillip Corrigan and Derek Sayer, The Great Arch: English State Formation as Cultural Revolution (Oxford: Basil Blackwell, 1985), 4, 9.
} 
central to its functioning. Colonial subjects also regulated and shaped rituals and mechanisms of power through performance when using such forms of political power. They were able to use institutions and legal mechanisms of the colonial system, yet creatively adopted them to build their discourses and tend their particular needs. This was a process in which both state agencies and subjects participated.

I propose that Spanish colonialism was able to establish a common discourse or legitimizing framework through the law in the Indies. This dissertation demonstrates the existence of this common ethos by analyzing colonial subjects' adoption and reproduction of the diverse Spanish legal system's forms offered to colonial subjects. Even if these subjects did not believe in the power behind these forms of rule, the use and appropriation of the colonial state’s symbols, words, and institutions, in everyday activities, both affirmed the power of the state and contributed to shape such forms. When royal officers designed and implemented administrative innovations, these were legitimated according to collective values or consciousness. The heterogeneous colonial population's participation in these rituals and activities did not necessarily demonstrate full-scale consent to subordination; rebellion and resistance could still take place. Yet the 
everyday participation in the rituals and performances of rule did affirm and shape the larger political system of Spanish imperial rule. ${ }^{33}$

I argue that the Spanish crown established a state apparatus that was not modern but functioned according to the parameters of its time. Within the common framework of the patrimonial colonial state, negotiation and compromise were valid and beneficial for both rulers and subjects. They provided flexibility and stability to the colonial system, which served to properly provide for each part of the political body. These were no signs of the weakness of the colonial state, but instead comprised very foundation of the political system.

This dissertation's focus on the post-1687 earthquake period demonstrates precisely how royal agents' exercise of power was limited by the common ethos. In the aftermath of the disaster, colonial subjects had the opportunity to use and appropriate, officially and unofficially, the state's forms, institutions, and symbols, including the culture of contracts and law so essential to Hapsburg rule. Consequently, the performance of bureaucrats and colonial subjects must be analyzed and understood

\footnotetext{
${ }^{33}$ Derek Sayer, “Everyday forms of State Formation: Some Dissident Remark in “Hegemony,” in Everyday forms of State Formation: Revolution and Negotiation of Rule in Modern Mexico, edited by Gilbert Joseph and Daniel Nugent (Durham: Duke University Press, 1994), 374-376.
} 
within the flexible and negotiable limits the Spanish system implemented. My

dissertation further shows that, in times of crisis, flexibility, negotiation, and

“conveniencia” allowed Lima’s people to successfully reconstruct their city and the early

modern state.

The Earthquake of 1687 appears in this analysis as a historical actor that tested the strength of the colonial state and temporarily halted reforms, but ultimately galvanized the process of early modern state formation. The post-disaster period offers various episodes that display the success of the colonial state in dealing with the increasing demands of a dispossessed population. As it imposed control and implemented reconstruction projects in the face of political opposition among the highest members of the non-monastic Church and the financial limitations of the royal treasury, the colonial state underwent a rapid and concentrated process of reformation. The examination of people’s participation in the city’s reconstruction demonstrates the existence of a common framework of legal and paralegal forms they validated and used in order to repair private property in the post-quake period.

\section{Methods and Sources}


Most of the primary sources employed in this dissertation are official

documentation from various colonial institutions, such as the city council, royal treasury, and ecclesiastical council. These documents provide diverse perspectives on the events being analyzed. Official correspondence, descriptive accounts, and even the personal letters of colonial authorities offer complementing or contrasting views of multiple administrative actors in diverse institutions, both religious and secular. Other kinds of official sources, such as notarial and court records, contain information about ordinary people's involvement in rebuilding activities and use of forms and forums of the Spanish legal system. Complementing the bulk of primary sources for this dissertation, personal letters and accounts offer data about ordinary peoples' views and participation in such reconstruction activities.

All together, these primary sources provide a multifaceted vista focused on the performance of both royal agents and colonial subjects responding to the quake. A close reading of the sources unveils the functioning of the colonial state and its attempts to impose authority and control; the restrictive rules that colonial administrators faced when trying to implement rebuilding projects; colonial subjects' expectations of royal agents and themselves; the negotiation among authorities and ordinary people over the terms of 
rebuilding the city; and the diverse social groups' understandings of justice shaped by

their own interpretation of law and custom.

\section{Overview of Chapters}

The story of the earthquake mainly proceeds chronologically, with one exception:

the last chapter goes back in time to provide an overarching analysis of the economic

challenges Viceroy Duke of Palata dealt with during his administration and his

subsequent plans to rebuild Lima. This is a diachronic analysis that examines the impact

of the earthquake on the series of reforms that both peninsular and colonial authorities

implemented during the years previous to the natural events, and how colonial subjects

performed within the parameters set by the colonial system.

Chapter 1 examines Lima as a principal city within the Spanish empire, a center

in the periphery, and focuses on the various dimensions of the early modern state in

Lima. The city's centrality to Spanish imperialism facilitates an analysis of the interplay

between both local and imperial administrations facing the quotidian and extraordinary

demands of a heterogeneous colonial population. The political and economic position of

Lima within the colonial Spanish territory demanded the constant attention of local and

royal agents in order to preserve the economic vitality of the city's neighboring port, 
which was the main port of the South Sea. The defensive structures that certain administrators built at the port of Callao predictably served to ward off pirate attacks. But the walls also unintentionally protected the port against nature. The chapter concludes by examining some of the administrative and fiscal reforms that Viceroy Duke of Palata developed within an environment of political antagonism, to demonstrate that the Spanish monarchy and its royal agents were able to introduce improvements and impose authority.

Chapter 2 evaluates the capacity of crisis management of the colonial administration in Lima after the Earthquake of 1687. The great intensity of the quake and extensive destruction of the city forced people to abandon their dwellings and look for alternative areas to provisionally relocate to. The Viceroy assembled the members of the city council in order to take the necessary measures to provide people with basic assistance. He also planned, negotiated, and initiated reconstruction projects to rebuild the main public building of the city, because it housed the principal branches of government and represented the power of the colonial state. The response by the royal agents in Lima after the earthquake contradicts dominant models of Spanish imperial state incapacity. 
The regular and secular clergy of the Catholic Church—long understood as a central branch of Spanish colonial governance--- responded differently in the postdisaster context of Lima, as explored in Chapter 3. This chapter recounts the material and spiritual activities of the religious orders, members of the Ecclesiastical Council, and the Archbishop of Lima. The religious orders actively provided spiritual assistance as soon as the first tremor hit the city. They also organized the rapid reconstruction of their monasteries and assisted other religious that were in need. But the members of the Ecclesiastical Council and the Archbishop were almost entirely absent and thus unable to provide the spiritual services that people needed. The Archbishop left the capital for various weeks to recover from injuries he suffered during the quake. The Viceroy took his place in the various religious functions that people performed in order to appease God's wrath, considered to be the cause of the intense quake. The Ecclesiastical Council and the Archbishop opposed the Viceroy’s plans to reconstruct the cathedral. They were mainly concerned with tending to their own material needs rather than providing spiritual aid to Lima’s flock, leaving a vacuum that secular authority had to fill.

The purpose of Chapter 4 is to demonstrate that, beyond top-down efforts, the success of state building owes to ordinary legal practices that the colonial population 
adopted and adapted in their everyday lives. In order to rebuild their private properties and estate holdings, Lima's population used, even informally, the forms and mechanisms the Spanish legal system offered. People and their corporations reached formal agreements before the ecclesiastical courts, or they legitimized previously-negotiated contracts before notaries. In cases where the value of property or money involved did not match the expense involved in going to court, colonial subjects resorted to extralegal arrangements, which were not necessarily recorded. Examples of these kinds of unofficial resolutions remain in the accounting book of a religious sodality whose administrator had the responsibility to repair the damaged properties of the congregation. Ordinary colonial people's practices of negotiation, and use of legal and paralegal forms reveal the success of the colonial state in imposing a common framework of rule that withstood the quake, and served as a strong foundation down to the lowest levels of society.

Chapter 5 shows that Spanish colonial administration, as part of a greater imperial project, promoted a series of inspections and reforms of the royal treasury of Lima that preceded the earthquake in the late seventeenth century. Beginning in 1677, the Crown ordered the inspection of royal treasuries of Lima and their administrators. This visita has been overlooked by most historians, resulting in an underestimation of the Hapsburg 
state's control over its royal agents and initiative to promote reforms. When the Duke of Palata arrived in 1681, the visita was suspended because of the death of the last inspector. The Duke had royal instructions to reactivate the visita, which resulted in the exile of one of the administrators of the royal treasury and the reduction of the debt owed to the king. The Duke also implemented measures to improve the fiscal system of the entire viceroyalty. The Earthquake of 1687 halted the collection activities of the royal administrators, who were working diligently after the exile of their old friend. In spite of the financial challenges caused by the 1687 earthquake, Lima’s remittances to Spain increased between 1685 and 1690 because viceroys had the obligation to send periodical remittances of bullion to the peninsula, despite the negative balance of the royal treasury. The visita and the Duke of Palata's reforms provisionally attenuated the critical condition of the royal treasury, even as the unexpected natural disaster interrupted them. The earthquake ultimately permitted both royal agents and subjects to galvanize the process of early modern state formation. If the reforms accentuated the crown's control and authority among the political elite in Lima, the earthquake multiplied the opportunities for limeños (or Lima’s inhabitants) to reinforce the crown's authority through their active use of the Spanish legal system. 
Ultimately, this dissertation explores the performance of the colonial state in Lima by combining various historical approaches. It portrays the Earthquake of 1687 as a historical actor that impacted the social, political, and economic structures of the colonial capital. The earthquake that hit Lima in 1687 laid bare the literal and metaphorical architectural bones of the colonial state, which were strong enough to withstand the turmoil and promote the recuperation of the city. The analysis of the post-disaster context reveals the colonial administration's capacity of crisis management as a skill in the art of government, as civil administrators provided for what was “conveniente” for colonial subjects according to their social standing. The active participation of Lima's population in the activities of reconstruction demonstrates the existence of a common legal framework that penetrated various levels of society and served as a crucial foundation for the ongoing process of rebuilding the city and the colonial state.

\title{
II. CHAPTER 1. THE EPICENTER OF THE SOUTH SEA: THE CITY OF
}

\author{
LIMA IN THE LATE SEVENTEENTH CENTURY
}


The city of Lima ranked among the main urban centers of the Spanish empire in the New World. It became the political, economic, religious, and cultural center of the Spanish domains in South America. A large population of diverse backgrounds settled in Lima because of the ample opportunities available in the locality. The city rapidly grew in size and splendor, which required greater attention from the metropolis. As the capital of the viceroyalty of Peru, Lima hosted the headquarters of various administrative, religious, and commercial institutions.

Lima’s political and economic development derived from its geographical location in the midsection of coastline along the South Sea. It became the gatekeeper to the riches of the Andes and center of the commercial networks in the viceroyalty. Along with these diverse advantages, Lima’s setting also had certain inconveniences. It was vulnerable to pirates’ attacks that periodically sailed along the viceroyalty’s coast. Among other natural events such as droughts, floods, and epidemics, earthquakes hit the city from time to time. Since early modern people considered unforeseen events as results of God's will, the reaction to such events was to plea for divine mercy rather than take any kind of preventive measures for future occurrences. ${ }^{34}$

\footnotetext{
${ }^{34}$ Gideon Sjoberg, “Disasters and Social Change,” in Man and Society in Disaster edited by George W. Baker and Dwight W. Chapman (New York: Basic Books, 1962), 363.
} 


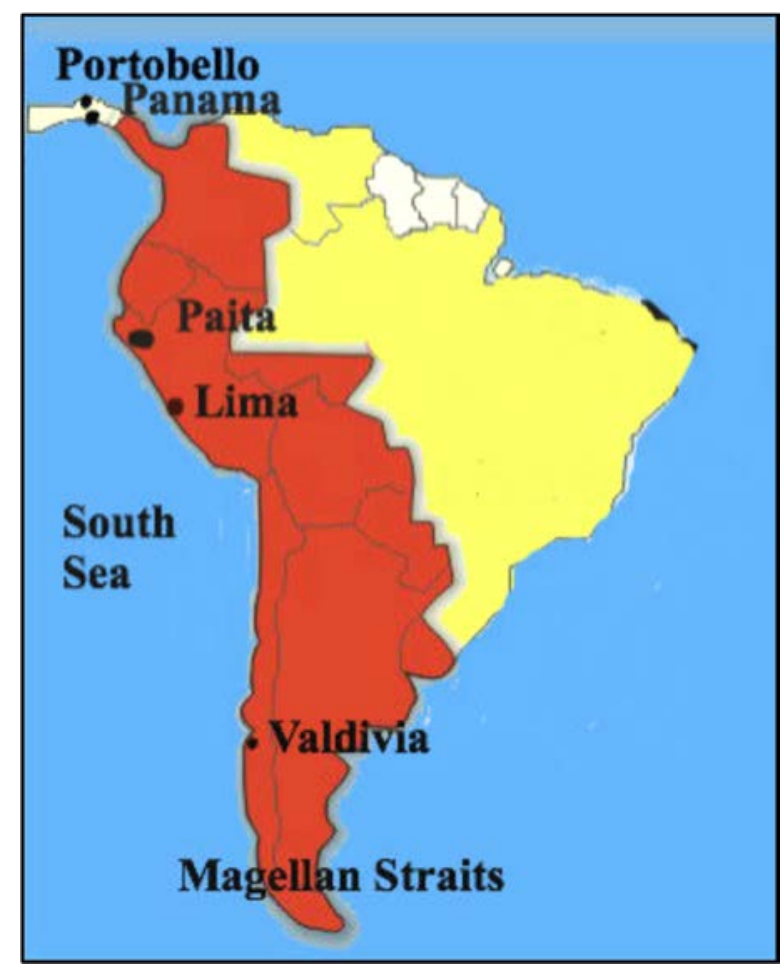

Image 1: Lima, capital of the Viceroyalty of Peru ${ }^{35}$

Historical records describe colonial authorities' efforts to implement measures to defend the city, yet these were more reactive than proactive. Royal representatives and subjects were more concerned about the tangible threat from pirate crews than natural phenomena, which were typically unforeseen. Despite the fear and economic threat pirates represented, authorities were hesitant to invest in building structures that would represent large expenses to the royal treasury. Royal representatives had the obligation to

35 Image made by the author. 
periodically send revenues to the metropolis and had to justify any extraordinary disbursement of royal treasury's monies. The subsequent constructions of defense structures demonstrate how royal agents responded to the demands from locals, for protection against pirates, and from the monarch, for remittance of revenues.

Despite the prominent position of Lima and recurrent pirate incursions, royal officers were unable to liberally use the royal treasury's monies to build defensive structures along the coast. They faced the predicament of having to balance the interests of the ruler and the locals. Even though Lima provided significant and constant revenues to the crown, it never was a priority in the politics of the court in Madrid. While it was an important center among the New World colonies, it was still the periphery of the Spanish Empire.

Lima's position as the center in a periphery is critical to this work because it highlights the interplay between imperial and local interests. ${ }^{36}$ Even though the term 'periphery' has a negative connotation, it describes the remoteness that even viceregal

\footnotetext{
${ }^{36}$ Anna Laura Stoler and Frederick Cooper, 'Between Metropole and Colony. Rethinking a Research Agenda," in Tensions of Empire. Colonial Culture in a Bourgeois World edited by Anna Laura Stoler and Frederick Cooper (Berkeley: University of California Press, 1997), 5.
} 
capitals had in the mind of the metropolis' authorities. ${ }^{37}$ Both peninsular and colonial authorities recognized that distant colonial domains required a certain degree of freedom in administrative matters. Certainly, distance permitted some arbitrary practices among royal officers, yet they were also obliged to bridge the distance. In order to do so, they recorded their decisions and activities, provided accounts of these in constant correspondence to the king, and consequently sought royal approval as a means to legitimate their behavior.

The construction of the wall of Lima, specifically, displays how state practices of negotiation allowed colonial authorities to rule among the seemingly contradictory interests of the monarch and a provincial center. Ultimately, this chapter demonstrates that, even when authorities pushed innovative ideas or projects, they had to evaluate their implementation according to the conditions of both the locality and the empire.

\section{The City of the Kings}

Attracted by stories of riches in the Incas' lands, Francisco Pizarro and his party reached the coast of today's Peru in 1528. After capturing the ruling Inca Atahualpa and bringing under control a large part of his domains, the Spanish conqueror decided to found

\footnotetext{
${ }^{37}$ Sylvia Sellers-Garcia, Distance and Documents at the Spanish Empire's Periphery (Stanford: Stanford University Press, 2014), 15, 16.
} 
a city that would function as capital of a new Spanish kingdom he intended to establish.

Once he eliminated other possible settlements, Pizarro founded the city of Lima or "City of the Kings” in $1535 .{ }^{38}$

The new city was established on the southern margin of the Rimac River, a couple of miles away from the coast. ${ }^{39}$ The limits of the city and adjacent farms extended over an area formed by the slope of the rivers Rímac, Chillón (on the north), and Lurín (on the south). ${ }^{40}$ The city had a natural port, Callao, that had functioned since pre-Hispanic times. In a few years, it became the most important port of the South Sea, as the Pacific Ocean was called. $^{41}$

\footnotetext{
${ }^{38}$ Raul Porras Barrenechea, Pequeña Antología de Lima. El río, el puente y la alameda (Lima: Universidad Nacional Mayor de San Marcos, 1965), 25, states some sources indicate the name of "City of the kings" referred to the Spanish kings, and others to the Epiphany day. Juan Günther Doering and Guillermo Lohmann Villena, Lima (Madrid: Colecciones MAPFRE, 1992), 54, state that according to the father Cobo, the conquerors wanted to honor the Epiphany because in the same days those from the East were in the desert looking for Belen, they were in the sands between Pachacamac and Lima, looking for a place for their new city.

${ }^{39}$ Porras Barrenechea, Pequeña Antología de Lima, 26.

${ }^{40}$ Günther \& Lohmann, Lima, 15.

${ }^{41}$ Reinhard Augustin Burneo, Las Murallas Coloniales de Lima y el Callao (Lima: Editorial Universitaria, 2012), 44.
} 
The Spanish monarch confirmed the foundation of Lima and its name of "The City of the Kings” in 1536. A few days after the foundation of the city, Pizarro established the local administration of the city with the appointment of the two first alcaldes ordinarios of the city. The increasing preeminence of Lima is reflected by the diverse grants and status improvements it received during the following decades: Pope Paul III promoted Lima to bishopric in 1541, and archbishopric in 1546; and the Crown elevated it to capital of the new viceroyalty of Peru, created in 1542, and issued the royal decree to found the first university of the Indies, San Marcos, in $1551 .^{42}$

At the time of the foundation of Lima, Pizarro distributed the first plots among the 30 vecinos, or elite residents, of the city. ${ }^{43}$ Lima's layout was similar to a checkerboard. It consisted of 117 blocks, each divided in 4 plots. ${ }^{44}$ Pizarro assigned the plot in front of the

${ }^{42}$ Günther \& Lohmann, Lima, 54, 59, 70, 71, 75, 87.

43 John K. Chance, Race and Class in Colonial Oaxaca (Stanford: Stanford University Press, 1978), 4, explains that during the first decades after conquest vecinos were European household heads, who received a lot and some land, and even Indian labor (encomiendas). They differed from moradores that had a fixed urban residence without land or encomienda grants. In Peru, a royal decree of 1554 allowed any Spaniard with a fixed residence to accede to vecino status. Thereafter, merchants, who usually lacked encomiendas, could receive such distinction.

${ }^{44}$ Porras Barrenechea, Pequeña Antología de Lima, 26. Alejandra Osorio, Inventing Lima: Baroque Modernity in Peru’s South Sea Metropolis (New York: Palgrave Macmillan, 2008), 13. 
eastern edge of the Plaza Mayor (Main Square) to be the first church, which was built by 1540. ${ }^{45}$ He chose the lot located on the northern edge for his own residence. After his death, the Crown seized Pizarro's properties and his palace became the residence of the future rulers of the viceroyalty of Peru. ${ }^{46}$ The plot Pizarro granted to his brother Hernando on the western edge of the plaza became the city council's building, in $1566 .{ }^{47}$

Lima rapidly outgrew the initial 13 blocks in length and 9 blocks in width of its foundation. ${ }^{48}$ The dimensions of the city's growth are evident by the foundation of multiple convents and monasteries, the addition of new plazas and blocks, and the appearance of new neighborhoods, such as San Lázaro and El Cercado. ${ }^{49}$ Lima received a constant flow of people from Europe, Africa, Asia, and other parts of the New World. They arrived to

${ }^{45}$ Günther \& Lohmann, Lima, 70. Pablo Patrón, Lima Antigua (Lima: Librería e Imprenta Gil, 1935), 3.

${ }^{46}$ Porras Barrenechea, Pequeña Antología de Lima, 129. Because Pizarro owed large quantity of pesos to the Crown by the time of his death, the monarch order by a royal decree that this property would be confiscated for the Crown.

${ }^{47}$ Günther \& Lohmann, Lima, 82.

${ }^{48}$ Osorio, Inventing Lima, 13.

${ }^{49}$ Günther \& Lohmann, Lima, 121, 122, state the San Lázaro neighborhood was a remembrance of the Triana neighborhood in Seville, and the governor García de Castro issued the creation of El Cercado to provide an exclusive area for the residence of Indians. 
stay either temporarily or permanently. In either case, they injected vitality to the city, which became the core of the Spanish viceroyalty in South America. ${ }^{50}$

By the mid-seventeenth century, Lima had reached 25 blocks in length and 14 in width. There were around 2,500 buildings without taking into account two neighborhoods that were outside the area considered the city properly. El Cercado, along the east side of the city, was constructed as a "reduction” (something like an urban reservation) of Indians, and housed around 200 dwellings. San Lazaro, located at the other side of the Rimac River, held 600 homes. It was originally a settlement of Indian fishermen, yet by the end of the century, it hosted people from diverse ethnic background as the rest of the city. ${ }^{51} \mathrm{~A}$ few decades later, in 1687, contemporary witnesses estimated the number of properties ascended to 4500, and the population of the city had increased to 50,000 people. ${ }^{52}$

\footnotetext{
${ }^{50}$ N. David Cook, La Catástrofe demográfica andina. Perú 1520 - 1620 (Lima: Fondo Editorial Pontificia Universidad Católica del Perú, 2010), 207.

${ }^{51}$ Günther \& Lohmann, Lima, 123.

${ }^{52}$ Letter from the Duke de la Palata to the King, December 8, 1687. Biblioteca Nacional de Madrid (hereafter BNM), MS. 9375; Account of the City Council, by Diego Fernández Montaño, December 4 1687. Archivo General de Indias (hereafter AGI), Lima, 87, 1v, 21v, 30v. Other witnesses that declared before the City Council's notary calculated the number of houses in around 5000.
} 


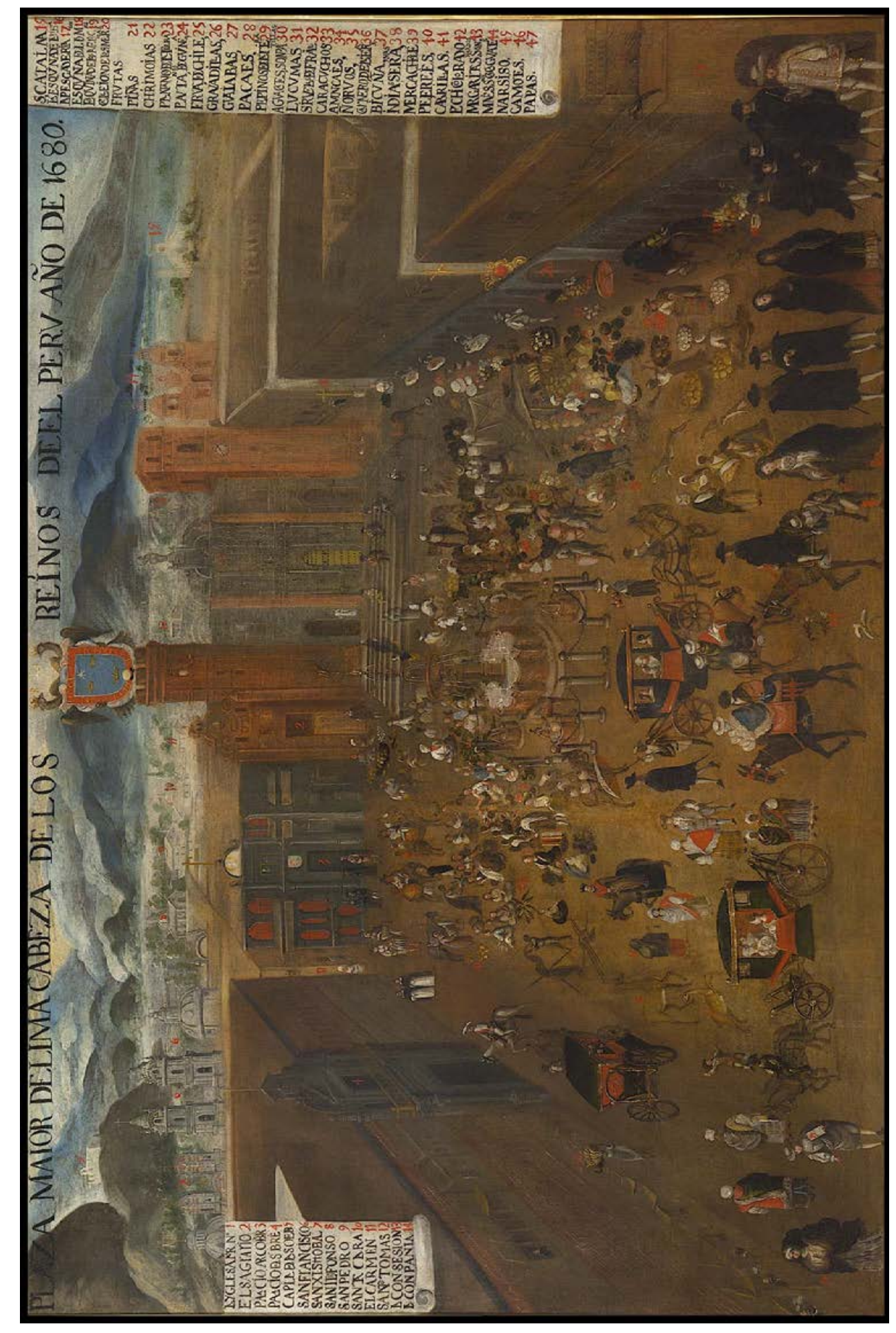

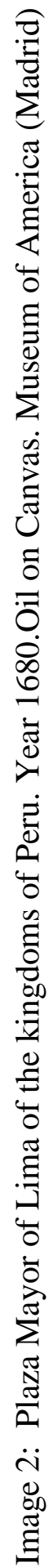


The Plaza Mayor maintained its position as the heart of the city, surrounded by political and mercantile buildings. On the northern side, the viceregal palace, formerly the home of Pizarro, accommodated the offices of the Real Audiencia, Real Acuerdo, Tribunal de Cuentas, Sala del Crimen, and Real Hacienda; the Royal Jail and the Royal Chapel; and the viceregal family's private rooms. ${ }^{53}$ The Cathedral, the Ecclesiastical Council's building, and the archbishop's palace shared the block on the eastern side. ${ }^{54}$ On the western edge, behind one of two portals that Viceroy Conde de Nieve (1561-1564) established, was the city hall with its jail, chapel, and the courtrooms of the cabildo. ${ }^{55}$ On the southern side, behind the second portal stood, various commercial stores of diverse genres. The adjacent streets to the Plaza Mayor and behind the first row of blocks around it had several artisan workshops and other diverse stores.

The same Plaza Mayor functioned as a market, called a Tianguez or "El Gato.”56 Vendors filled it with mobile stalls (cajones). In the tianguez, Indian vendors usually

\footnotetext{
${ }^{53}$ Günther \& Lohmann, Lima, 123; Porras Barrenechea, Pequeña Antología de Lima, 128; Patrón, Lima Antigua, 3.

${ }^{54}$ Porras Barrenechea, Pequeña Antología de Lima, 128.

${ }^{55}$ Patrón, Lima Antigua, 2.

${ }^{56}$ Porras Barrenechea, Pequeña Antología de Lima, 130.
} 
offered a large variety of crops that they brought from their fields. ${ }^{57}$ Beginning in 1548 , the city council assigned a place on the northeastern edge of the viceregal palace, called the alhóndiga, for the sale of meat and fish. ${ }^{58}$ Because of this local commerce, the city had a constant supply of fresh food products that required city council regulation in order to maintain fair prices and weights.

The presence of the various branches of the political power and the vitality of commerce paralleled the religious fervor of the city and its people. By the late 1680s, the city had sixty-five religious edifices: the Cathedral being the most important, four parishes, twenty convents, eleven monasteries, fifteen beneficence establishments, schools, and other similar institutions. ${ }^{59}$ Although secular priests, meaning priests with parishes, tended some of these places, religious orders—monks and missionaries-- oversaw most of them.

In only a few decades after the conquest, Lima had become the focus of the political, economic, and religious life of the viceroyalty of Peru. Its geographical position also offered several advantages to its population. Even today, the port of Callao is the most

\footnotetext{
${ }^{57}$ Patrón, Lima Antigua, 23, 24.

${ }^{58}$ Ibid, 25.

${ }^{59}$ Account of the City Council, f. 1v.; Patrón, Lima Antigua, 4-7.
} 
important commercial gate to the city and several of the interior provinces. Because the Humboldt Sea current runs along most of the Peruvian coast, Lima enjoys a moderate weather, neither too hot nor too cold for its latitude. ${ }^{60}$ Nonetheless, Lima's location also had negative effects.

\section{Threats to the Political and Economic Epicenter of the Kingdom}

Since Lima was the viceroyalty's commercial core, seat of the Consulado or wholesale merchants' guild, and headquarters of the Royal Treasury and other branches of the Spanish government, it enjoyed an economic and political supremacy that concerned upper-class limeños, who collectively dreaded possible rebellious outbreaks from lower social groups or attacks from other European powers.

Excluding the Inca attempt to expel the Spaniards from their lands, when Manco Inca sent an army of 50,000 men under the orders of his general Titu Yupangui in 1536, Lima did not suffer from recurrent Indian rebellions. ${ }^{61}$ In 1544, a group of 600 black slaves

\footnotetext{
${ }^{60}$ John P. Cole, Estudio Geográfico de la gran Lima (Lima: Oficina Nacional de Planeamiento y Urbanismo, 1957), III-7; Porras Barrenechea, Pequeña Antología de Lima, 18, states that despite its geographical location 150 meters over the sea, $12^{\circ} 2^{\prime}$ 50” latitude South, and $77^{\circ} 5^{\prime}$ longitude West, Unanue in El Clima de Lima described Lima had "neither excessive heat or intense cold or rainy abundant.”

${ }^{61}$ Günther \& Lohmann, Lima, 68.
} 
rebelled against the abusive treatment by the authorities appointed by Gonzalo Pizarro while he abandoned the city to fight Viceroy Blasco Nuñez de Vela. ${ }^{62}$ Even though none of these movements reached their objectives, Lima's residents kept the memory of such events. The idea of possible outbreaks against the political order generated a collective fear. ${ }^{63}$ In the next decades, royal authorities were able to discover and suffocate, before their initiation, subsequent subversive plots against the capital.

Besides its importance in economic and political terms, the capital's geographical location brought another threat to the city. The proximity of Lima to the coast and the lack of natural barriers to contain enemy attacks from the seashore became a tangible hazard. During the first decades after its foundation, Lima's authorities hesitated about erecting any defense structure to protect the city and the port because they were confident that adversary armies would be unable to reach the South Sea waters. The only passage available to Spain's enemy nations to enter the South Sea was the Strait of Magellan, whose current and winds were difficult to overcome.

\footnotetext{
${ }^{62}$ Burneo, Las Murallas Coloniales de Lima y el Callao, 22.

${ }^{63}$ Fernando Rosas Moscoso, “El miedo en la historia: lineamientos generales para su estudio," in El Miedo en el Perú, ed. Claudia Rosas .(Lima: Pontificia Universidad Católica del Perú, 2005), 28.
} 
With the objective of resisting possible rebellious movements, Viceroy Marques de Cañete III (1556 - 1561) organized the first militia companies, eight in total, to support the regular forces if necessary. The objective of this first military organization in Lima was to establish control and defend the city from dissident outbreaks, both native and Spanish, against the crown rule. Cañete completed the construction of the Casa Real in Callao, which served as storage for the Armada Real's equipment and supplies. ${ }^{64} \mathrm{He}$ also organized the first salaried troops. Yet the burden of these forces on the royal treasury generated antipathy among authorities at the peninsula, who pushed for the progressive reduction of salaries. Cañete’s main concern was to resist any possible Indian uprisings or conflicts between Spanish rival parties rather than fight against any external threat. ${ }^{65}$

When privateer Francis Drake reached the Port of Callao in 1579, royal administrators realized the vulnerability of Lima. ${ }^{66}$ It was after this experience that

${ }^{64}$ Burneo, Las Murallas Coloniales de Lima y el Callao, 45, the Casa Real also served as custom house and lodging for Armada's officers and other royal officials.

${ }^{65}$ Peter T. Bradley, Spain and the Defense of Peru, 1579 - 1700: Royal Reluctance and Colonial SelfReliance (Lexington: Lulu.com, 2009), 8 - 11.

${ }^{66}$ Guillermo Lohmann Villena, Las Defensas Militares de Lima y Callao (Lima: Academia Nacional de la Historia del Perú, 1964), 21, 22 states that Viceroy Toledo was able to halt Drake’s landing in front of Lima, and the intruder desisted from the attack because he was unaware of the presence of 200,000 pesos in the royal treasury. Bradley, Spain and the Defense of Peru, 7,13. 
authorities started to discuss the necessity of building defensive structures both in Lima and Callao. ${ }^{67}$ In 1583, after negotiations between the city council and the Real Audiencia, the construction of the first turret to protect the port began; yet, works were still in progress when an earthquake in 1586 destroyed it. ${ }^{68}$

It was the appearance of English corsairs in the South Sea, led by Thomas Cavendish the following year, that motivated royal authorities in Lima to reopen the discussion about the capital's security. ${ }^{69}$ Viceroy Conde de Villadompardo (1584-1589) rushed the construction of new turrets to protect the port. ${ }^{70}$ Despite the evident vulnerability of both Lima and its port, the next viceroy, Marques de Cañete V (1590-1596) disregarded the construction of protective structures. Even though he finally decided to build a military

\footnotetext{
${ }^{67}$ Lohmann Villena, Las Defensas Militares de Lima y Callao, 19, affirms that the initial discussion about erecting a fort in Lima took place in a cabildo's meeting, in 1537. Burneo, Las Murallas Coloniales de Lima y el Callao, 26, states that even though Drake did not land, he took valuable merchandise from ships he intercepted.

${ }^{68}$ Bradley, Spain and the Defense of Peru, 18; Burneo, Las Murallas Coloniales de Lima y el Callao, 45.

${ }^{69}$ Bradley, Spain and the Defense of Peru, 3, 13, states that Cavendish was the second English navigator in circumnavigating the southern passage to the South Sea.

${ }^{70}$ Lohmann Villena, Las Defensas Militares de Lima y Callao, 28, that conscious of the preparations to resist his attack, Cavendish headed north discharging his revenge over Paita, which he raided on may $29^{\text {th }}$, 1587.
} 
outpost to store artillery and serve as refuge in case of internal or external attacks, Viceroy Marques de Cañete and other royal officers continued believing that the military strength of the kingdoms relied mainly on mobile elements of defense, such as troops and ships, rather than defensive structures such as fortifications. ${ }^{71}$

By the end of the century, pirates sailed across the capital in the South Sea but without any attempt of an attack. ${ }^{72}$ The sense of security among Lima's authorities and residents did not last long because German corsair Joris Van Spilbergen, and his Dutch crew appeared in front of the Peruvian coast by the end of 1614. They approached the capital in July of 1615 and began to attack the port. Apparently, the defensive structures in front the port discouraged Spilbergen and his crew because they suddenly halted the assault. The pirates sailed to the north where they attacked more accessible ports, such as Paita, which they burned down. ${ }^{73}$

${ }^{71}$ Ibid, 29.

${ }^{72}$ Bradley, Spain and the Defense of Peru, 30-32, this was another Dutch expedition, under the command of Olivier van Noort.

${ }^{73}$ Lohmann Villena, Las Defensas Militares de Lima y Callao, 34 - 38; Burneo, Las Murallas Coloniales de Lima y el Callao, 33, affirms that the pirates were decided to take the capital, yet Callao's fortifications provided a resistance they have not expected. They abandoned the attempted after shooting only two shots, sailing to the north coast where they attacked Huarmey and Guayaquil. This pirate fleet navigated to Acapulco and later to Philippines. It finally returned to Holland in 1617. 
The constant presence of pirates along the western coast of the kingdom and the destruction of ports motivated the colonial authorities to build defense structures to protect Lima and Callao from similar attacks. Viceroy Marques de Montesclaros (1607-1615) initiated the construction of a defensive platform to protect Callao's Casas Reales and the port. His successor, Principe de Esquilache (1615 - 1621), followed the same defensive policy and expanded the work envisaged by Montesclaros. ${ }^{74}$ He designed a defensive system consisting of three bastions arranged along the coast to protect the port. ${ }^{75}$ Unfortunately, the Consejo de Indias did not support his project and reproved the Viceroy’s initiation of such works without royal permission, diverting sources from the royal treasury to such defensive projects. ${ }^{76}$ Nonetheless, Esquilache’s efforts became evident few years

\footnotetext{
${ }^{74}$ According to Burneo, Las Murallas Coloniales de Lima y el Callao, 46, the Principe de Esquilache’s defensive fortifications consisted of a series of trenches and parapets along the coast in front of Callao. Bradley, Spain and the Defense of Peru, 41, 56, argues that Esquilache realized the serious danger the enemies entailed because he personally suffered a long delayed in Panama, and land journey from Manta (Ecuador) to Lima, to avoid falling into pirates' hands.

${ }^{75}$ Lohmann Villena, Las Defensas Militares de Lima y Callao, 39 - 42; Burneo, Las Murallas Coloniales de Lima y el Callao, 46, the three turrets were: Santa María, northern to the port on the Rimac River's mouth; San Francisco, on the middle of the port's harbor; and Santa Ana, on the farthest extreme of the harbor.

${ }^{76}$ Lohmann Villena, Las Defensas Militares de Lima y Callao, 43 - 45; Bradley, Spain and the Defense of Peru, 44.
} 
later when the protective system he implemented withstood a long and strong attack against the port of Callao.

It was the well-informed and armed fleet of Dutch Jacques Clarck L'Hermite that tested Esquilache's defensive structure. The enemies besieged Callao for several months. ${ }^{77}$ The illness and ensuing death of the leader and many crewmen, and the unsuccessful attacks to other ports of the viceroyalty depleted the Dutch's enthusiasm who finally abandoned the enterprise. ${ }^{78}$ As soon as he received the news of L'Hermite's approach, Viceroy Marques de Guadalcázar (1622-1629) initiated the works of a complex of military battlements in Callao. Both Lima's authorities and residents shared the expenses of theses constructions. ${ }^{79}$ The exigencies of the time demanded such combined financial efforts.

\footnotetext{
${ }^{77}$ Burneo, Las Murallas Coloniales de Lima y el Callao, 34, states Callao' besiege lasted four months between May and August 1624.

${ }^{78}$ Lohmann Villena, Las Defensas Militares de Lima y Callao, 56 -68.

${ }^{79}$ Bradley, Spain and the Defense of Peru, 70, 71, mentions that Guadalcázar added three more turrets to the two remaining ones that Esquilache ordered to build. The marquis also added a castle, San Felipe de los Pozuelos, on the eastern shoreline of La Punta. With all these fortification, this viceroy erected the first integrated defensive system in the coast; Lohmann Villena, Las Defensas Militares de Lima y Callao, 66.
} 


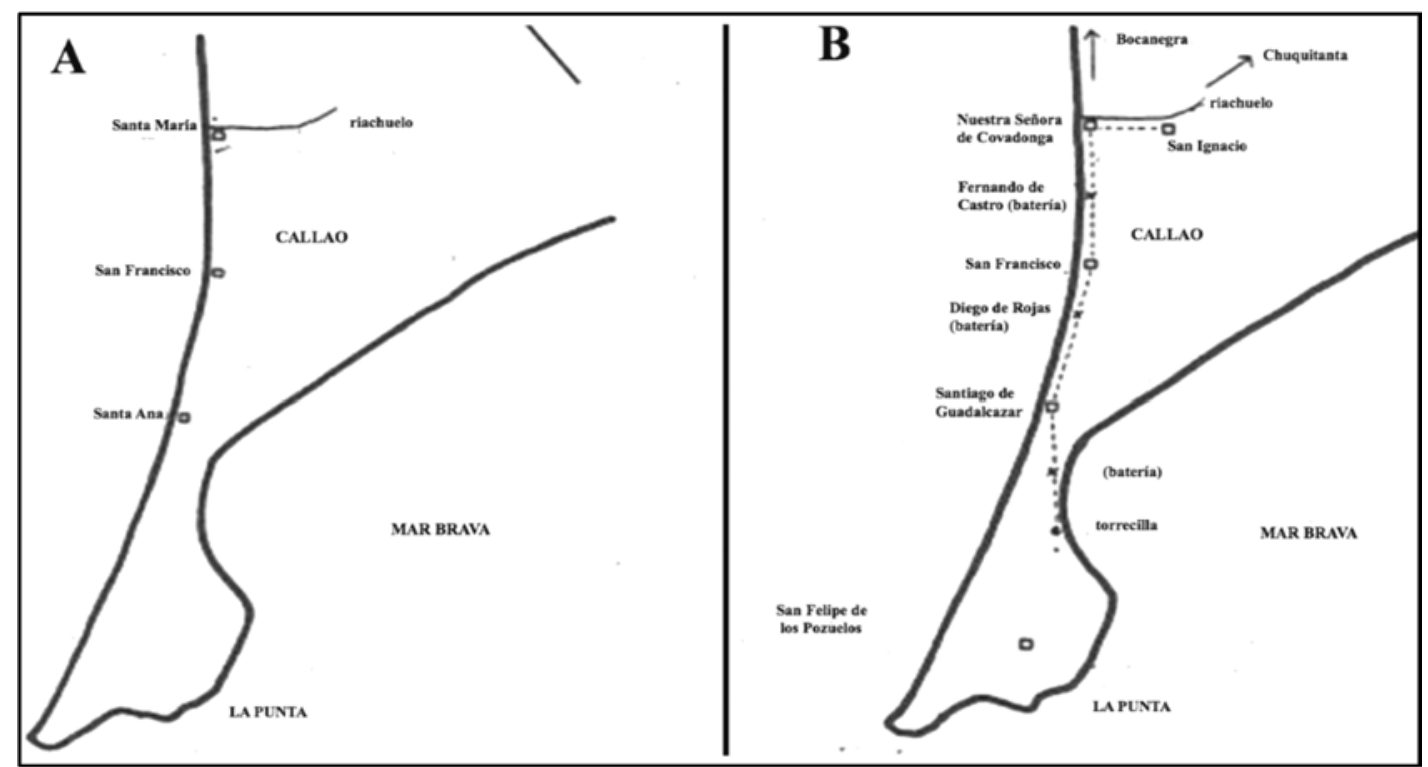

Image 3: Fortifications under (A) Principe de Esquilache and (B) Marquis of Guadalcazar. $^{80}$

L'Hermite's long and organized attack on the viceroyalty's capital also concerned peninsular authorities because it paralyzed commerce, halted the remittance of revenue, and destroyed several ships. ${ }^{81}$ The Council of Indies initially approved the organization of a fleet to defend the South Sea. Yet these initiatives rapidly faded. Despite the tangible effects that the pirate's attack produced on the viceroyalty's coastal towns and port, the peninsular authorities hesitated to spend royal revenues to build protective structures, not

\footnotetext{
${ }^{80}$ Guillermo Lohmann Villena, “Murallas y Fortificaciones del Perú Durante el Virreinato,” in Atlas Histórico y Geográfico del Perú: Descubrimiento, Conquista y Virreinato, edited by Carlos Milla Batres, tomo 2 (Lima: Editorial Milla Batres S.A., 1996), 182.

${ }^{81}$ Bradley, Spain and the Defense of Peru, 42-43.
} 
even to protect Lima, which was the headquarters of the viceroyalty's royal treasury. It would take more than a decade to reopen discussions about Lima and Callao's defensive constructions in the Consejo de Indias.

For colonial subjects, especially those living along the coast of the viceroyalty, the threat of the pirates was clear and evident. News of the destruction of various ports along the South Sea circulated rapidly, accentuating the fear against such tangible dangers of latent attacks. ${ }^{82}$ For this reason, Lima's population consistently supported the initiatives to build defensive buildings that some rulers or the city council proposed. They even demanded from these authorities the construction of these defenses. When Viceroy Marques de Mancera arrived in Callao in 1639, he was determined to reinforce the viceroyalty's capital and main port's defenses. ${ }^{83}$ The news of pirate attacks against the ports of Valdivia and Portobello at the beginning of 1640 accentuated the necessity of

\footnotetext{
${ }^{82}$ Ramiro Flores, “El enemigo frente a las costas. Temores y reacciones a la amenaza pirata, 1570-1720,” El Miedo en el Perú. Siglos XVI al XX edited by Claudia Rosas (Lima: Fondo Editorial de la Pontificia Universidad Católica del Perú, 2005), explains that the pirates generated fear among Spanish colonial subjects who viewed them as foreigners and heretics that could both establish political alliances with traitors of the king and introduce profane practices among the local population.

${ }^{83}$ Ibid, 80, affirms that the new Dutch post on northeast Brazil concerned Mancera.
} 
reinforcing the security of the port. Mancera gathered Lima's main royal officers to plan the construction of a wall around Callao, without burdening the royal treasury. ${ }^{84}$

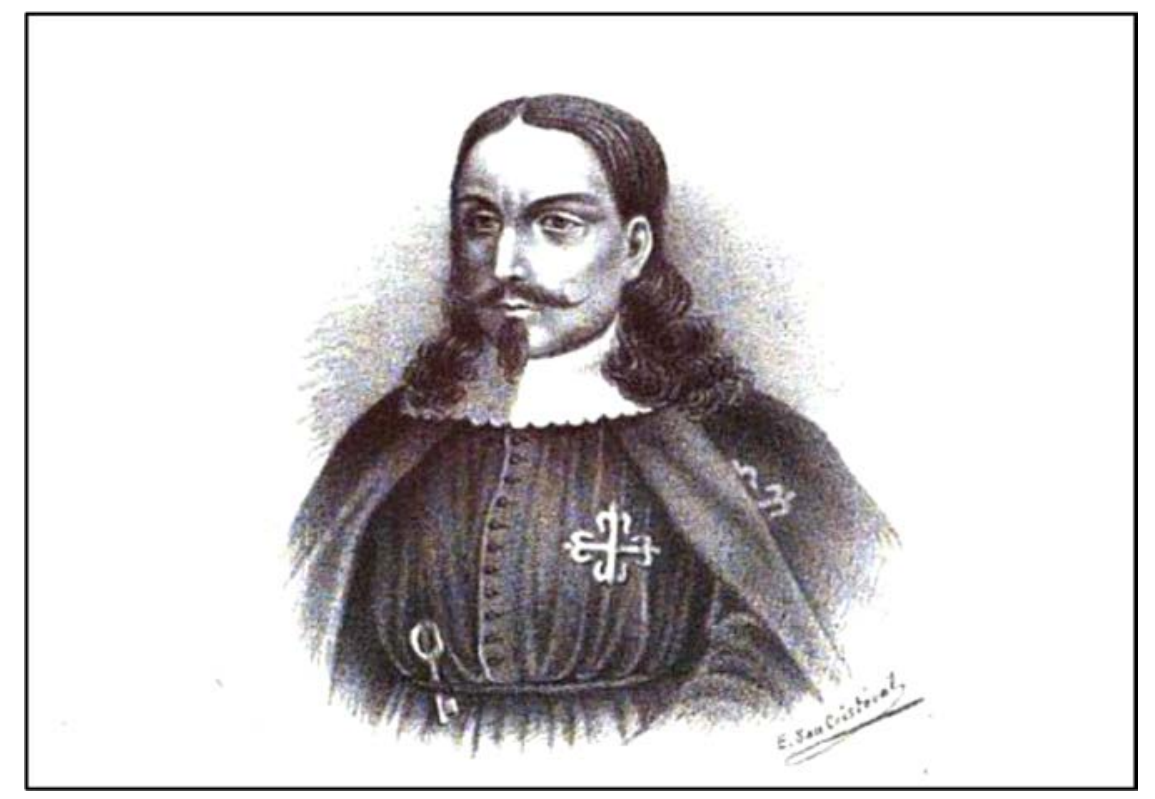

Image 4: Marquis of Mancera ${ }^{85}$

Royal representatives' initiatives to build defensive structures to protect the capital

were frequently obstructed by the responsibility to protect the king’s treasury. The Council

of Indies had reprimanded Viceroy Principe of Esquilache for using funds from the royal treasury for building defensive structures without requesting previous authorization.

\footnotetext{
${ }^{84}$ Toledo y Leiva, Manuel de. “Memoria de Gobierno,” in Memorias de los Virreyes del Perú. Marques de Mancera y Conde de Salvatierra (Lima: Imprenta del Estado, 1899), 45, Mancera recounts there were various meetings with both military and civil authorities of the city to discuss and determine the better means to defray the construction and maintenance of the wall.

${ }^{85}$ Juan Antonio de Lavalle, Domingo de Vivero, and Evaristo San Cristóbal. Galería de Retratos de los Gobernadores y Virreyes del Perú (1532-1824) (Lima: Librería Clásica y Científica, 1891), n.p.
} 
Viceroy Mancera’s predecessor, Marquis of Chinchón, built four batteries to protect the interior side of the port, which was vulnerable to incursions from land. Chinchón planned the construction of additional parapets of stone to complement the defense of the batteries. ${ }^{86}$ Yet he had to desist from this project because he considered it unaffordable. ${ }^{87}$ In order to build the wall around Callao, Mancera had to negotiate carefully with the main authorities in the city the means to afford the building expenses without using royal funds. The construction project of this wall relied mainly on new taxes and the compulsory free labor of blacks in the capital. After extensive deliberation, the royal officers established new duties on meat and sugar, products of basic consumption whose distribution were supervised by the city council. They also allocated to the building project 12,000 pesos the meat supplier offered to pay annually for the right to sell his product. The royal agents also ordered that one out of ten blacks in the city would take turns providing their labor. ${ }^{88}$ The building activities began at the end of 1640 and lasted six years.

\footnotetext{
${ }^{86}$ Bradley, Spain and the Defense of Peru, 1579 - 1700, 75, describes that Viceroy Chinchón built such 4 batteries which cost 60,000 pesos in 1631 . The additional defense structures would increase the expenses to 100,000 pesos. For that reason, the Viceroy decided to stall this project.

${ }^{87}$ Victor Álvarez Ponce, “El Mar y las Políticas Preventivas en el Perú Virreinal: Impacto, Control y Vulnerabilidad ante los Tsunamis (1647-1751)” (MA Thesis: Pontificia Universidad Católica del Perú, 2014), 28.

${ }^{88}$ Toledo y Leiva, “Memoria de Gobierno,”45.
} 


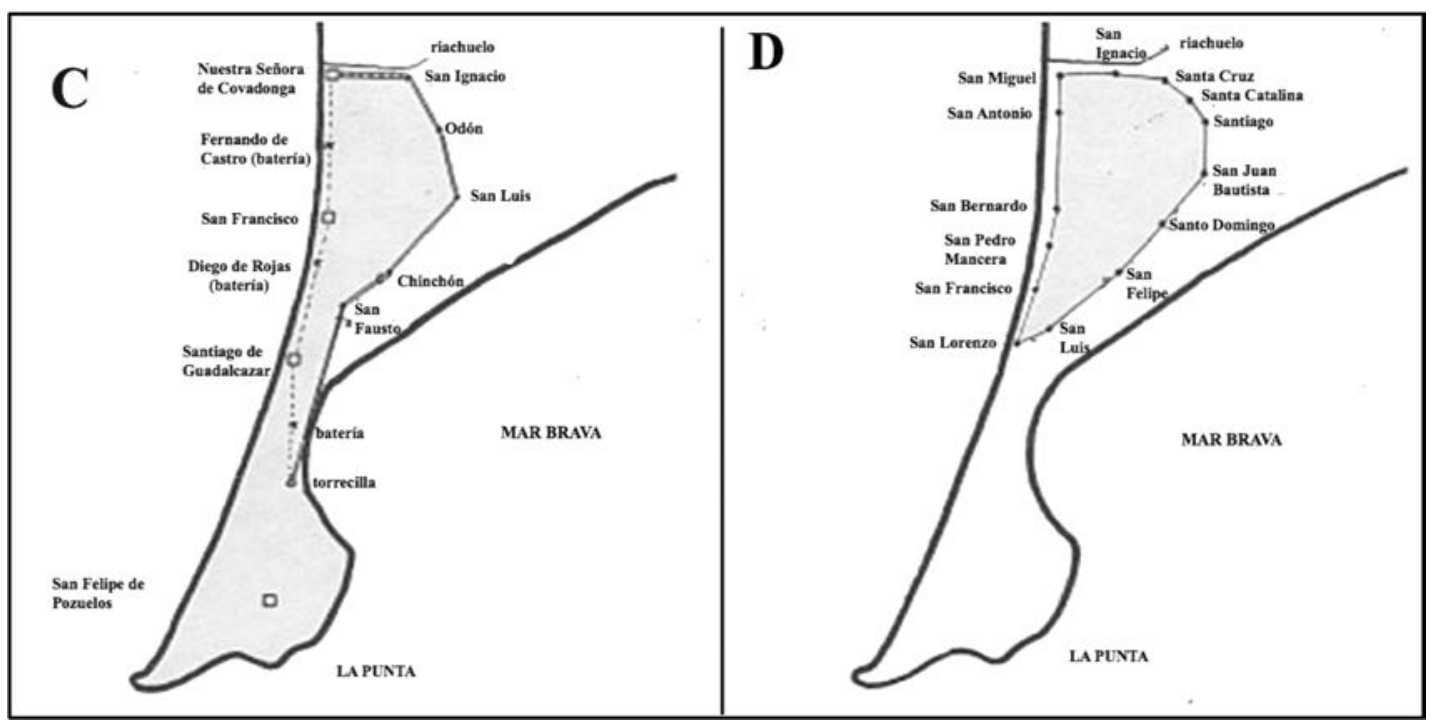

Image 5: Fortifications made by (C) Count of Chinchón, and (D) Count of Mancera. ${ }^{89}$

In order to avoid the criticism received by Esquilache, Mancera convinced peninsular authorities that the construction of this wall would reduce rather than increase royal treasury expenses. Mancera justified his decision to initiate the project by clarifying to his superiors that additional taxes and economic obligations would provide enough revenue to pay for the building and maintenance of the entire project. He also explained that the new defensive structure would require only a half of the current number of troops allocated to the port, which would represent a reduction of 100,000 pesos in annual salaries. ${ }^{90}$

\footnotetext{
${ }^{89}$ Lohmann Villena, “Murallas y Fortificaciones del Perú Durante el Virreinato,” 182.

${ }^{90}$ Ibid, 45; Bradley, Spain and the Defense of Peru, 85.
} 
On the other hand, political struggles in the metropolis also increased the urgency of the construction. The rebellion of Portugal, initiated in 1640, exacerbated fears of the subjects loyal to the Spanish monarch. They were afraid that the rebels, concentrated in Brazil, would provide support to the Dutch pirates that constantly circumnavigated the coast of the Peruvian viceroyalty. Royal officers were concerned that the union of Dutch and Portuguese enemies would attack the scarcely populated cities of Buenos Aires, Tucumán, and Paraguay, from where they could reach the mining centers of Alto Perú. ${ }^{91}$

The erected wall converted Callao into a fortified commercial port-city, yet it left out the Indian village of the Pitipiti, which remained exposed to the ferocity of the pirates and the sea. ${ }^{92}$ The construction of this wall amounted to 876,000 pesos, which did not include labor force costs in order to reduce expenses, because Mancera forced slaves and condemned prisoners to work for free. He also obligated merchant vessels to freely

\footnotetext{
${ }^{91}$ Lohmann Villena, Las Defensas Militares de Lima y Callao, 94.

${ }^{92}$ Burneo, Las Murallas Coloniales de Lima y el Callao, 43, 53, refers the Pitit-Piti natives lived in the coast of La Punta y Chuquito before Hispanic presence. Their main settlement was located north to the Spanish port, next to a small creek called Callao. Because they were the main suppliers of maritime products to the capital, the Spaniards permitted the Piti-Piti to continue their traditional activities and organizational structure. Unprotected by the Callao's wall, the tsunami of 1687 destroyed this native village completely.
} 
transport the stones available in the islands across the capital to the construction site. ${ }^{93}$ Unfortunately, the final product was overshadowed by the large debt the construction left for the royal treasury, and subsequent rulers continued neglect of maintaining and repairing the defenses. ${ }^{94}$

As the incursions of pirates in the South Sea decreased during the following decades, the fear of tangible enemies, such as Drake and L’Hermite, waned. The military significance of the Callao's wall and the other fortifications turned into economic burdens on the royal treasury. Subsequent rulers complained about the expense of repairing the defensive structures from time to time. ${ }^{95}$ During the following decades, there was not a serious discussion about improving the capital's defenses. The fortification of Lima in the 1680s resulted once again from potential threats.

In the late 1660s, two Indian rebellions and a new wave of pirate attacks in the South Sea reopened the debate on the construction of the city wall in a Junta de Guerra. From these meetings emerged the project that would materialize in the construction of the

${ }^{93}$ Bradley, Spain and the Defense of Peru, 85.

${ }^{94}$ Ibid, 87, when Mancera left the post of viceroy, expected taxes and levies experienced a shortage which resulted in an unpaid balance of 247, 504 pesos out of the 867,000 pesos paid by the royal treasury.

${ }^{95}$ Lohmann Villena, Las Defensas Militares de Lima y Callao, 126-130. 
city wall of Lima. The construction project by Jesuit Juan Raymond Coninck attracted the interest of Lima's authorities, who referred the plans and designs to the Council of Indies for consultation. ${ }^{96}$ Unfortunately, the pirate threat faded again and the peninsular authorities tabled the project, which they did not consider an immediate necessity.

The progressive addition of defensive structures and the construction of the wall to protect Callao and Lima kept pace with paralleled periods of imminent and perceptible danger over the city. Even if the population of Lima did not directly see the pirates' fleets crossing the South Sea, their presence was real enough. Rumors and official news rapidly reached and circulated through the capital. Regardless of the extensive distance between the metropolis and the capital of the Peruvian viceroyalty, peninsular authorities perceived the danger of pirates' presence when the customary routes of commerce and revenue remittances suffered delays. Nonetheless, as soon as the threat subsided, both authorities and ordinary people lost interest in the building of defensive structures, which became an economic burden rather than a military advantage. Concerns of tangible and imminent threats left people, specifically royal authorities, unprepared against invisible, and unpredictable threats that could strike Lima.

${ }^{96}$ Burneo, Las Murallas Coloniales de Lima y el Callao, 110. 


\section{Lima, the Land of the Tremors}

The city of Lima is located over a seismic zone, where the Nazca and South American tectonic plates merge. This geological confluence is responsible for both the physiognomic and seismological configuration of the city and its coast. The movement of both plates produced the formation of both Lima's alluvial fan, which has a drastic change in slope in only a few miles, and the maritime placket along the seashore, which generates periodical seismic movements. ${ }^{97}$ For this reason, tremors and earthquakes have constantly afflicted Lima.

The Spanish chronicles offer the first written records of seismic events in the New World. These accounts include testimonies about tremors that struck in the decades before the arrival of the conquering parties. None of these sources provides a precise date, but only an approximate time with brief descriptions of the events. The first seismic event the

\footnotetext{
${ }^{97}$ Günther \& Lohmann, Lima, 18, 19. Lizardo Seiner Lizárraga, Historia de los sismos en el Perú. Catálogo: Siglos XV-XVII (Lima: Universidad de Lima Fondo Editorial, 2009), 17, explains that this convergence is located over a larger system, the Ring of Fire or Circum-Pacific Belt, of tectonic plates that runs along the coasts of the Pacific Ocean. Seiner argues that 80 percent of the telluric events, in the whole world, occur from the collision of plates of this system.
} 
Spaniards faced in the Inca territory happened in 1533 as Pizarro and his party advanced through the Peruvian coast to the city of Cusco. ${ }^{98}$

In the decades that followed, the viceroyalty's capital and main port suffered from quakes and other natural events, such as surges. In the progressive construction of defensive structures, the authorities had not considered the protection of Lima and Callao from natural events but instead focused on the imminent and tangible threats of pirates. Nonetheless, the wall of Callao played a protective role against nature's forces, which royal authorities did not foresee. Even though the construction of this wall was not culminated until July of 1647, it protected people and material property when tidal waves hit the port in May of that year. On this occasion, the wall shielded 5 million pesos of merchandise stored in the royal warehouses from flooding. In 1651, the wall played the same function, safeguarding 3 million pesos of goods. ${ }^{99}$ Yet, the lack of maintenance works contributed to the progressive decay of the wall, as royal authorities began to overlook its defensive value against pirates, whose presence in the South Sea became sporadic. Despite the

\footnotetext{
${ }^{98}$ Seiner Lizárraga, Historia de los sismos en el Perú, 86, refers this telluric event happened in the night between January 31 and February 1, 1533, when the Spanish party was in the coast of Chancay.

${ }^{99}$ Lohmann Villena, Las Defensas Militares de Lima y Callao, 122-123.
} 
decreasing military protection it rendered after a few decades, the wall continued providing protection to the port against natural events.

When the pirates returned in 1680, the incumbent viceroy rejected projects of additional defensive constructions. Lima's population reacted with consternation when they got the news of English pirates approaching the capital. Despite the popular support to build a wall to protect Lima, Archbishop Melchor de Liñan y Cisneros, who also served as interim viceroy at that time, dismissed the report that recommended such construction and the reinforcement of various ports in the South Sea. ${ }^{100}$

\section{The Archbishop and the Duke}

Among the various royal officers that appear in this dissertation, Don Melchor de Liñán y Cisneros and Don Melchor de Navarra y Rocaful, the Duke of Palata, were the most powerful authorities in Lima during most of the 1680s. Their careers in the service of the Crown were outstanding but not exceptional. They represent bureaucrats who developed successful careers and accumulated extensive experience in the imperial domains through the diverse posts they occupied. At the same time, they exemplify the

\footnotetext{
${ }^{100}$ Burneo, Las Murallas Coloniales de Lima y el Callao, 118, the report belonged to the engineer Luis Venegas Osorio, Visitador de las Fortificaciones de Tierra Firme y de los Puertos de la Mar del Sur.
} 
frequent clashes, not only between the religious and the secular realms, but also among royal agents.

By the time King Charles II appointed him as archbishop of Lima in 1676, Melchor de Liñán y Cisneros had already filled several ecclesiastical posts in both the peninsula and the New World. ${ }^{101}$ Only few months after the new archbishop arrived in Lima in 1678, the King named him interim viceroy to replace Count of Castellar. The former viceroy abandoned the capital and headed to the northern port-city of Paita, where he was awaiting the outcome of the audit process related to his tenure as viceroy. ${ }^{102}$

Even though the Archbishop-viceroy had served the Spanish crown since 1661, as priest of the Spanish court's parish of San Salvador and calificador (examiner) of the Holy

\footnotetext{
${ }^{101}$ Margaret Ellen Crahan, Clerical Immunity in the Viceroyalty of Peru, 1684-1692: a study of civilecclesiastical relations (PhD Dissertation, Columbia University, 1967), 179, 180; Manuel de Mendiburu, Diccionario Histórico - Biográfico del Perú, vol. 7 (Lima: Enrique Palacios, 1933), 4.

102 José Manuel Valega, El Virreinato del Perú: historia crítica de la época colonial en todos sus aspectos (Lima: Cultura Ecléctica, 1939), 78, states that Charles II had deposed Castellar because of some accusations the Consulate and Audiencia presented against this viceroy. Margarita Suárez, Desafíos Transatlánticos. Mercaderes, banqueros y el estado en el Perú virreinal, 1600 - 1700 (Lima: Fondo Editorial Pontificia Universidad Católica del Perú, 2001), 374 - 376, also affirms that the merchants of Lima were behind the destitution of Castellar, who earned the enmity of the Consulate when he allowed the entrance to the city of Asian merchandise that ships from New Spain brought. In his "juicio de residencia" the Count resulted absolved from such charges.
} 
Office of the Inquisition, he performed most of his services for the crown in the New World. In 1664, Phillip IV appointed him as bishop of Santa Marta (modern Colombia). In the following years, he received the posts of Bishop of Popayán in 1666, Archbishop of Charcas in 1672, and Archbishop of La Plata in 1674. The King also entrusted Liñán y Cisneros with the post of Visitor General of the Kingdom of New Granada, which he exercised between 1666 and $1674 .{ }^{103}$ In order to fulfill the various responsibilities entrusted to him by the King, Liñán y Cisneros had to travel across the kingdom visiting many provinces and meeting the diverse population of Spanish South America. ${ }^{104}$ The experience he accumulated during these years of service permitted the Archbishop-viceroy to know firsthand the multiple conditions and needs of the Peruvian viceroyalty. This kind of mobility was not uncommon among administrators, and permitted royal appointees, who had similar trajectories, both to recognize the diverse regions that formed part of the Spanish empire and develop specific policies to deal with the particularities of each region.

\footnotetext{
${ }^{103}$ Mendiburu, Diccionario Histórico - Biográfico del Perú, vol. 7, 4.

${ }^{104}$ Crahan, Clerical Immunity in the Viceroyalty of Peru, 180, 181, affirms that Liñán y Cisneros never lead the bishopric of Charcas because he received notification of his new appointment to La Plata before he was able to take possession of such post.
} 
In 1680, when English pirates advanced again towards the capital, the Archbishopviceroy reacted as many of his predecessors had by increasing the number of troops and ships rather than erecting defensive constructions. ${ }^{105}$ Even though peninsular authorities had forwarded the project proposed by Jesuit Coninck to build a wall around Lima to the Council of Indies in 1673, the recent pirate attacks on Panamá motivated the Council to appoint Luis Venegas Osorio to assess the fortifications in Tierra Firme and the South Sea in $1680 .{ }^{106}$ The next year in Lima, Osorio presented his report to the Archbishop-viceroy, who dismissed the recommendation to build a fortification along the western coast of the viceroyalty and a wall around Lima. ${ }^{107}$ One of the Archbishop-viceroy’s main arguments against Osorio's report was that the construction of a wall around Lima would require the destruction of several properties, which ran along the project's plans. ${ }^{108}$ These properties, as most others in the city, provided periodic rents mainly to religious individuals and corporations. Even when limeños became concerned because of the close proximity of

\footnotetext{
${ }^{105}$ Lohmann Villena, Las Defensas Militares de Lima y Callao, 176, refers a group of pirates under the orders of Edward Wolmen sailed along the Pacific coast attacking Arica in 1681.

${ }^{106}$ Burneo, Las Murallas Coloniales de Lima y el Callao, 118.

${ }^{107}$ Bradley, Spain and the Defense of Peru, 162.

${ }^{108}$ Lohmann Villena, Las Defensas Militares de Lima y Callao, 177.
} 
pirates, Liñán y Cisneros ignored their demands to construct a wall to protect the city. He maintained a clear tendency to favor the interests of the religious communities rather than those of the secular population whom he also governed. The task of building the wall of Lima had to wait a few more years until another viceroy made the decision to turn Coninck’s project into a reality.

For the few years Liñan y Cisneros occupied both roles, as head of church and state, he mainly concentrated on reforming the religious orders, and taking advantage of the rights over ecclesiastical matters he had as viceroy. ${ }^{109}$ Overburdened by the responsibilities of both positions, the Archbishop-viceroy suggested to the King the appointment of a viceroy that would exclusively fulfill his secular duties. ${ }^{110}$ Though he knew he could not handle both positions, he displayed animus toward his predecessor, the Count of Castellar, and even greater antipathy toward his successor, Don Melchor de Navarra y Rocafull, Duke of Palata. ${ }^{111}$ The antagonism between the Archbishop and the Duke would intensify in the following years.

${ }^{109}$ Crahan, Clerical Immunity in the Viceroyalty of Peru, 74.

${ }^{110}$ Enrique Sánchez Pedrote, “Los prelados virreyes,” Anuario de Estudios Americanos 7 (1950), 24.

${ }^{111}$ Mendiburu, Diccionario Histórico - Biográfico del Perú, vol. 7, 10; Crahan, Clerical Immunity in the Viceroyalty of Peru, 78, 79, argues that the conflicts between Liñán and Castellar emerged out of the permanence of the latter in Paita for the duration of his prolonged juicio de residencia. The presence of 
In 1654, Navarra y Rocafull, soon to be a duke, began to serve the Spanish crown when he was only twenty-eight years old. Because of his exceptional aptitude as a law student in Salamanca, he received the posts of adviser to the General Government of Aragón in 1654 and Visitor to the Real Audiencia of Barcelona in 1657. He became a member of the Council of Naples, the Council of Italy, the Council of War, and the Council of State. He served as Supreme Council of Italy prosecutor, Vice-Chancellor of the kingdom of Aragón, and member of the Junta de Gobierno (1665-1675) that ruled during the minority of King Charles II. ${ }^{112}$

In 1662, he became Duke of Palata and Prince of Massa, through his marriage to Doña Francisca Toralto de Aragón in Nápoles. ${ }^{113}$ In 1680, the monarch appointed him General Captain and Viceroy of Perú. After a trip that lasted more than eight months and took him through Cartagena and Portobello, the Duke and his retinue arrived in Paita on

\footnotetext{
Castellar within the limits of the viceroyalty accentuated his partisans' opposition to the Archbishopviceroy's administration.

${ }^{112}$ Crahan, Clerical Immunity in the Viceroyalty of Peru, 183; Mendiburu, Diccionario Histórico Biográfico del Perú, vol. 8. (Lima: Enrique Palacios, 1933 - 34), 60.

${ }^{113}$ Francisco Fernández de Béthencourt, Historia Genealógica y Heráldica de la Monarquía Española: Casa Real y Grandes de España, vol. 3. (Madrid: Establecimiento Tipográfico de Enrique Teodoro, 1901), 581.
} 
September 13, 1681. When he arrived in Callao the following month, the Archbishopviceroy went personally to Callao to welcome him. The new viceroy's official entrance to Lima took place on November 20. ${ }^{114}$

Upon his arrival in Lima, the Duke recognized the climate of antagonism created by the confrontations between the factions of the Archbishop and Count of Castellar, who had recently departed from Peru, after waiting for years for the result of the inspections of his administration. The Duke tried to halt these conflicts by choosing ministers unrelated to both parties. Nonetheless, the appointment of high court minister Don Joseph del Corral Calvo, a Castellar partisan, as his advisor put the Duke under the direct influence of an opponent to Liñán y Cisneros. ${ }^{115}$

The antagonism between the Archbishop and the Duke placed real constraints on the latter's administration. The Archbishop continuously critiqued the measures the Duke attempted to implement, especially those from his own initiative. Yet the Duke was able to counteract the Archbishop’s accusations and complaints before the King through the many improvements he promoted in the colonial administration during his government.

\footnotetext{
${ }^{114}$ Valega, El Virreinato del Perú, 80.

${ }^{115}$ Margaret Crahan, “The Administration of Don Melchor de Navarra y Rocafull, Duque de la Palata: Viceroy of Peru, 1681-1689,” The Americas 27, no. 4 (April 1971): 392.
} 


\section{The Duke's Reforms and the Lima Wall}

During the seven years he ruled the Peruvian viceroyalty, the Duke of Palata attempted several reforms in different areas of the colonial administration. Some of these reforms were his own initiatives while others were instructions from the crown or innovations from previous royal representatives. In order to halt the increasing smuggling of ore and evasion of the quinto real (tax of 20 percent on mining extraction), the Duke proposed that a royal mint be established in Lima. He argued to the crown that this Casa de la Moneda would produce the coinage that public and private commercial transactions required. After confronting opposition from both Seville and Potosí, which had their own coining centers, the Viceroy reached his goal in 1683 when the King issued the order to establish a Casa de la Moneda in Lima. ${ }^{116}$

The Duke also implemented new measures to improve the production of silver and quicksilver. After several meetings, he signed a new contract with Huancavelica miners’ representatives, where he committed the crown to supply the necessary native labor force. ${ }^{117}$ The Duke justified the need for this new contract based on the fact that the

\footnotetext{
${ }^{116}$ Mendiburu, Diccionario Histórico - Biográfico del Perú, vol. 8, 74; Crahan, “The Administration of Don Melchor de Navarra y Rocafull,” 376.

${ }^{117}$ Crahan, “The Administration of Don Melchor de Navarra y Rocafull,” 398.
} 
previous one, signed in 1645, was not fulfilled by the crown. The old contract stipulated the crown should provide 620 Indian laborers so the miners could produce 6,820 quintals of quicksilver every year. The royal treasury also owed the miners 600,000 pesos for the quicksilver received and some repair expenses, which were responsibility of the crown. After a collapse in 1681, the mine required additional repairs that amounted to 200,000 pesos. The miners agreed to repair the mine if they received 3,000 quintal of mineral in exchange for their labor. In order to negotiate the terms of the new contract, the Viceroy gathered three royal ministers that had served at Huancavelica to discuss the requests by the miners' representatives. The Viceroy finally granted the miners the quicksilver requested, which was valued at 225,000 pesos. He also restituted an old grant from a particular to the crown, which would provide 110,000 pesos annually to fund the hospital for Indians. In order to reduce laborers' burden, the Duke stipulated miners would pay Indians their entire salary regardless of the quantity of mineral they obtained and cover their tributes to the crown. The new contract transferred the repair cost from the royal 
treasury to private interests, increased the production of mineral, and sought to improve the conditions of Indian laborers. ${ }^{118}$

The Duke also restituted the possession of the Descubridora mine, the largest mercury mine in the Indies, after negotiating with various creditors, who claimed the crown owed them several unpaid Indian laborers’ salaries. Don Diego Tamayo, one of the crown’s creditors, went to the court in Madrid to request a Castilian nobility title from the King, the corregimiento of Arequipa for four years, and three knighthood habits for his daughters' partners in exchange for 107,000 unpaid Indians' daily wages. Eventually, the Duke reached a settlement with Don Joseph Tamayo, Don Diego Tamayo’s heir and brother, who agreed to receive only the corregimiento. To other creditors that claimed similar rights, the Duke awarded either a knighthood habit or a corregimiento, in exchange for the concession of their claims. ${ }^{119}$

In order to increase the workforce in the mining regions of Huancavelica and Potosí, Viceroy Duke of Palata ordered a massive registration of the Indian population that

\footnotetext{
${ }^{118}$ Melchor de Navarra y Rocafull, “Memoria de Gobierno, 16 de agosto de 1689,” in Los virreyes que han gobernado el Perú durante el tiempo del coloniaje español, vol. 2. (Lima: Librería Central de Felipe Bailly, 1859), 163 -167; Mendiburu, Diccionario Histórico - Biográfico del Perú, vol. 8, 74 - 76.

${ }^{119}$ Navarra y Rocafull “Memoria de Gobierno,” 179 - 181.
} 
began in 1683. Even though this census concluded seven years later, when another viceroy was in charge of the viceroyalty, the colonial administration was able to double the number of forced native workers, mitayos, in Postosí from 10,427 to 20,829. ${ }^{120}$ The Duke recognized that this census, as well as other innovations he proposed and implemented, was necessary to reform the administration and production of the viceroyalty.

The Duke strongly supported fiscal reforms promoted from the metropolis; yet he also introduced his own initiates. He closely supervised the operation of the royal administrators in charge of Cajas Reales. He supported the inspection of the royal treasury and its administrators that the King had ordered in 1662, and reorganized the activities and personnel of Tribunal de Cuentas, with the intention of improving the fiscal performance of his administration and obtaining the bullion he periodically had to remit to the crown. ${ }^{121}$

The Duke also promoted those initiatives from his predecessors which he considered useful. For instance, he encouraged the use of small vessels to transport silver to Panama because they were less expensive to the royal treasury than using the royal fleet

\footnotetext{
${ }^{120}$ Crahan, “The Administration of Don Melchor de Navarra y Rocafull,' 377; Mendiburu, Diccionario Histórico - Biográfico del Perú, vol. 8, 80.

${ }^{121}$ Mendiburu, Diccionario Histórico - Biográfico del Perú, vol. 8, 73. Kenneth Andrien, Crisis and decadencia. El Virreinato del Perú en el siglo XVII (Lima: Instituto de Estudios Peruanos, 2011), 241, 242.
} 
(armada real). The original purpose of the South Seat royal fleet was to ensure the shipping of silver to Panama and shipping of merchandise to the capital. From 1664, in response to the decay of silver exportation, royal officers reduced the sailing frequency of the royal fleet from every year to every three years. Aware of the excessive cost of construction and maintenance of large ships required by the fleet, the Duke resorted to private small vessels to meet similar needs instead of the royal fleet, which in the 1680s only sailed two times. The Duke encouraged this alternative means of transportation, initiated by his predecessor Viceroy Principe de Esquilache, because it transferred the cost of the vessels from the crown to private hands. ${ }^{122}$ Despite economic, political, and environmental difficulties, Duke of Palata was able to dispatch five fleets during the seven years of his government carrying revenue remittances to the peninsula. ${ }^{123}$

One of the most difficult challenges he faced was the presence of pirates in the South Sea during great part of his administration. During his journey from Madrid to Lima, the Duke passed through Portobello at the beginning of 1681. Pirates Sharps, Wolmen, and

\footnotetext{
${ }^{122}$ Bradley, Spain and the Defense of Peru, 1579 - 1700, 108, 115.

${ }^{123}$ Memorial ajustado y resumen de lo actuado en la residencia del Señor Virrey Duque de la Palata, December 3, 1690. AGI, Lima, 87, f. 11, shows Palata dispatched fleets in 1682, 1685, 1687, 1688, and 1689. The three years that these ships did not depart responded to the presence of pirate in the South Sea, which motivated Lima’s merchants refused to send their capitals to Portobello in the royal fleets.
} 
Warlen had attacked this port the previous year, and the Duke was conscious of the potential damage similar attacks could inflict on other ports. When he arrived in Lima, he found out that a large part of the population appealed for a wall to protect their city. ${ }^{124} \mathrm{Like}$ many other rulers that preceded him, the Duke perceived the pirates as a tangible and close threat for the capital and its people. Even though Liñán y Cisneros had rejected Osorio’s recent report, the Duke was determined to complete Lima's wall project. The main obstacle to build the defensive structure was the precarious condition of the royal treasury, which discouraged royal authorities in both the metropolis and the colony from investing in infrastructural projects.

Determined to build the wall around Lima, Palata presented Coninck’s project to the King in 1682, attaching his own comments to support it. Among his suggestions, the Duke proposed various new means of revenue to support both the construction and maintenance of the wall, such as a selling tax on meat, monetary fines on crimes, the rents of some encomiendas, one month of the monthly payments of leases and other rental contracts, 10 pesos tax for each negro bozal introduced in the city, and the creation of a monopoly of sealed paper. The Viceroy and the city counselors also recommended that

\footnotetext{
${ }^{124}$ Burneo, Las Murallas Coloniales de Lima y el Callao, 119 - 120.
} 
those who could not contribute with money would work without compensation, and that farmers would contribute 4 reales for each fanega produced. ${ }^{125}$ Some months later, the Junta de Guerra in Spain dispatched the plan of Conick to the Duke of Bournonville, Viceroy and Captain General of Catalonia, who was an experienced architect in military structures. Bournonville recommended some modifications to the plan, but overall did not make substantial alterations. ${ }^{126}$ In 1685 , the Junta de Guerra finally accepted the revised project.

Nonetheless, news of a pirate attack under the leadership of French Chevalier de Grammont and Dutch Laurence de Graaf to the port of Veracruz reached Lima in 1683, reviving anxiety and fear among the population. The commotion generated by this event was so great that clerics preached about it in their sermons. Every sermon the Viceroy attended referred to fortresses, towers, and walls. He felt everyone was preaching to him trying to convince him of the need of a wall. ${ }^{127}$ Motivated by this conjuncture, the Viceroy

\footnotetext{
${ }^{125}$ Navarra y Rocafull, “Memoria de Gobierno,” 368.

${ }^{126}$ Bradley, Spain and the Defense of Peru, 130 - 132; Burneo, Las Murallas Coloniales de Lima y el Callao, 120.

${ }^{127}$ Navarra y Rocafull, “Memoria de Gobierno,” 366; Burneo, Las Murallas Coloniales de Lima y el Callao, 121.
} 
summoned the city council on October 23, 1683 to discuss the means to obtain the 700,000 pesos that Coninck estimated for the completion of his project. ${ }^{128}$

The Viceroy and the city council approved several measures and new taxes that, although considerable, were deemed necessary to build the wall. In order to obtain additional financial support, the Viceroy negotiated with the various corporative groups in the city. He offered a personal donation of 50,000 pesos before requesting contributions from different corporations of the city. His negotiations were rewarding. The Consulado offered to build 3,000 yards of wall. The Ecclesiastical Council, the University of San Marcos, and the religious orders of Santo Domingo and La Merced donated 10,000 pesos each; and the Society of Jesus promised to build a bastion om the wall. ${ }^{129}$

On November 1683, the Duke sent another missive to the King requesting the approval of the measures proposed in the meeting with the city council. Without awaiting royal authorization, the building activities began the next year. Royal approval, issued in 1685, arrived in Lima along with Bournonville’s recommendations. The King granted the Duke freedom to choose the means to fund the wall, underlining that they would have to cover also its maintenance. Among the various new income sources, the Viceroy had

\footnotetext{
${ }^{128}$ Burneo, Las Murallas Coloniales de Lima y el Callao, 121.

${ }^{129}$ Ibid, 124.
} 
suggested a monopoly on paper bearing the royal seal. Even though the monarch initially rejected the idea, he finally agreed because of the benefits it would generate to both the administration and the population. The monopoly was a big concession and a great administrative innovation. It produced better control on the quantities of official paper introduced in the capital and fixed the price of each sheet. The royal treasury would obtain a fixed income according to the quantity sold, and people would be able to purchase paper at a fixed price the entire year. ${ }^{130}$ Given the widespread use of this paper for business and legal transactions, this was a considerable source of revenue.

By 1687, the city seemed well-protected against pirate attacks because of the new wall. It covered a surface of 14,000 yards with 34 bastions and 5 gates. The structure left out the neighborhood of San Lázaro on the other side of the Rimac River, and passed through El Cercado by the middle. ${ }^{131}$ Even though pirates attacked several ports and came

\footnotetext{
${ }^{130}$ Crahan, "The Administration of Don Melchor de Navarra y Rocafull," 402, states that the proceeds of this monopoly financed naval improvements rather than the wall. Also see Burneo, Las Murallas Coloniales de Lima y el Callao, 141.

${ }^{131}$ Mendiburu, Diccionario Histórico - Biográfico del Perú, vol. 8, 95; Navarra y Rocafull, "Memoria de Gobierno,” 367 - 375, before the estanco the price of each ream of paper varied each year between armada and armada. During the first year after the armada, the price of the paper varied between $5 \frac{1}{12}$ and 6 pesos per ream; and increased in the next years reaching up to 12 pesos each ream. The estanco fixed the price to 7 pesos per ream of sealed paper.
} 
close to Callao, they never attempted an invasion of Lima. The danger the limeños had foreseen never arrived; instead, what unexpectedly came was a very destructive earthquake on October 20.

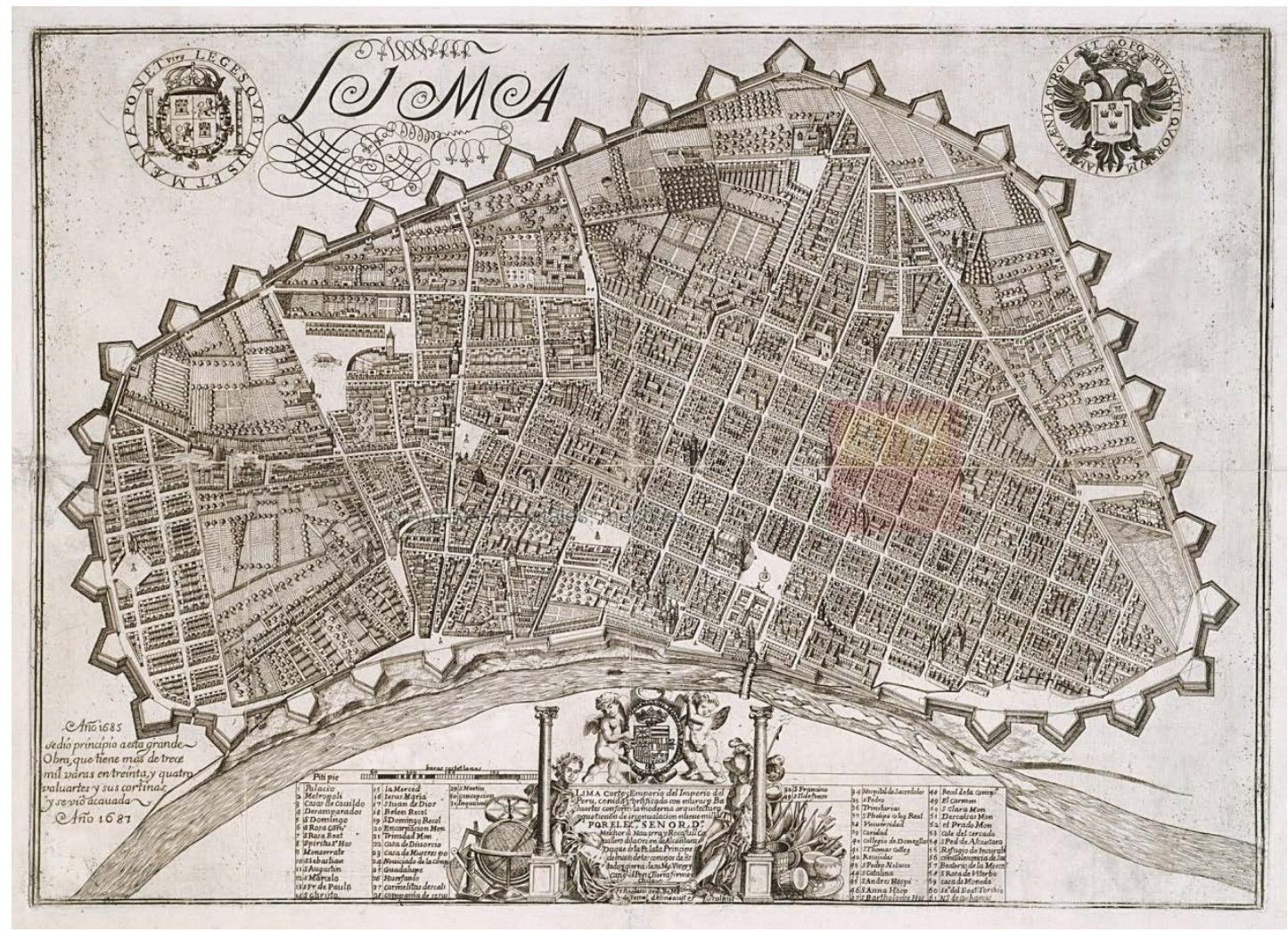

Image 6: Map of the city of Lima and its fortifications, $1687^{132}$

132 Plano de la Ciudad de Lima y sus fortificaciones, Fray P. Nolasco from the Order of the Merced, 1685. AGI, MP-PERU_CHILE, 13. The script on the bottom left corner says “Año 1685 se dio principio a esta grande obra que tiene de trece mil varas en treinta y quatro baluartes y sus cortinas y se vio acabada. Año 1687 " 
On April of 1687, only 6 months before the destructive earthquake of October, four tremors knocked Lima. The common reaction of the population was the multitudinous assistance to masses and processions. Nonetheless, people were mainly concentrated on the construction of the wall, concerned by the concrete threats of pirates in the South Sea. ${ }^{133}$ Despite several reactive displays of concern, Lima's population never really took stock of whether they were prepared to face another quake.

\section{Conclusion}

As the capital of the Peruvian viceroyalty and one of the most important colonies of the Spanish empire, Lima had a central role in the Spanish world. It was both core and periphery because it was the heart of a colonial dominion. It became one the main cities of the New World with a large and diverse population, both transient and permanent. As an economic and political center, Lima had a constant flow of people and goods from outside and inside the viceroyalty. In a few decades, Lima occupied a place of supremacy in the region in commercial, administrative, religious, and cultural matters.

The geographical position of Lima brought some benefits to the city, but it also produced some hardships. Located next to the coast, Lima's port, Callao, permitted

\footnotetext{
133 Josephe de Mugaburu and Francisco de Mugaburu, Diario de Lima (1640 - 1694): Crónica de la época colonial (Lima: Imprenta C. Vasquez, 1935), 265 -270.
} 
commerce to flourish in the city. Wholesale merchants consolidated power through their own guild, the Consulado. Pirate fleets, proceeding from Spain’s enemy nations, constantly approached Callao and other South Sea ports attracted by the viceroyalty's riches, which were accumulated in the capital before their remittal to the Spanish metropolis.

Lima's strategic position was jeopardized by the seismic ground on which it sat. Lima suffered from periodical tremors and earthquakes. Nonetheless, the recurrence of these natural events had not motivated authorities to develop a policy to deal with them by 1687. During the colonial period, royal administrators were mainly concerned with more palpable threats such as the invasion of pirates. Even when facing these tangible circumstances, colonial authorities hesitated to build defensive structure to defend the capital and its port, and they were mainly focused on protecting the royal treasury from excessive expenses.

Peninsular authorities entrusted colonial administrators, especially viceroys, the duty of dispatching revenues periodically to the metropolis. In order to prevent overburdening Lima's royal treasury, royal officers had to resort to alternative sources for economic support. In order to realize their building projects, both viceroys Mancera and later the Duke of Palata summoned royal officers under their orders to discuss possible new 
means of revenue. Despite the flexibility they exercised in negotiating with colonial authorities and corporations, and regardless of the positive outcome of these negotiations, the viceroys had to ultimately justify their actions before the monarch. The king, along with his Council of Indies ministers, could either legitimize or censure the decisions of his colonial representatives. In order to avoid being the object of criticism like Esquilache, Mancera justified the wall of Callao project by citing the reduction in military expense to safeguard the port and demonstrating that the construction would not burden the royal treasury. Similarly, Duke of Palata had to justify his various initiatives such as the contract with the Huancavelica miners, the administrative reform of the Tribunal de Cuentas, the use of small vessels to transport silver in the South Sea, and finally the construction of the Lima wall.

The pending earthquake would cause great destruction and chaos. Lima's authorities had to face exceptional conditions that they did not expect. Duke of Palata had to concentrate his efforts on reconstructing the city rather than promoting reforms. Despite great obstacles to the rebuilding projects, the Viceroy realized them with the support of local authorities and ordinary people. The analysis of Lima's reconstruction, within the 
larger context of Duke of Palata's administration, offers an ideal context to observe the interplay of imperial rule, local government, and people.

\section{CHAPTER 2: CAPACITY, CRISIS MANAGEMENT AND COLONIAL ADMINISTRATION: THE VICEROY AND THE CITY COUNCIL}

With the construction of Lima's wall almost complete, Viceroy Duke of La Palata saw one of the greatest projects he pursued as head of the viceroyalty of Peru literally built before his eyes. The frightening idea of pirates raiding the viceroyalty capital disappeared in the horizon over the South Seas once a tangible form of protection firmly stood surrounding the city. For many, Lima seemed finally prepared to resist the attack of its enemies. But an unexpected attack of nature hit instead.

On October 20,1687, at around four in the morning, a series of telluric movements woke up Lima's residents. People rushed to the street; others were trapped by crumbling ceilings and walls. Dust made the night darker, and confusion prevailed everywhere in the city. A few minutes later a tsunami hit and flooded Callao, the principal port of the South Sea, inflicting great damage to neighboring Indian villages. The wall of the city-port could not contain destructive blast of large tides that destroyed property and took many lives. In 
a matter of a few hours, the city of Lima was in ruins, its population dispossessed and seeking refuge in nearby open areas. As the head of the central government of Peru, Viceroy Don Melchor de Navarra y Rocafull, Duke of Palata, spearheaded the reconstruction activities. ${ }^{134}$ He mobilized and organized other royal officials to maintain social control, tend the population's increasing basic needs, and plan the reconstruction of the city.

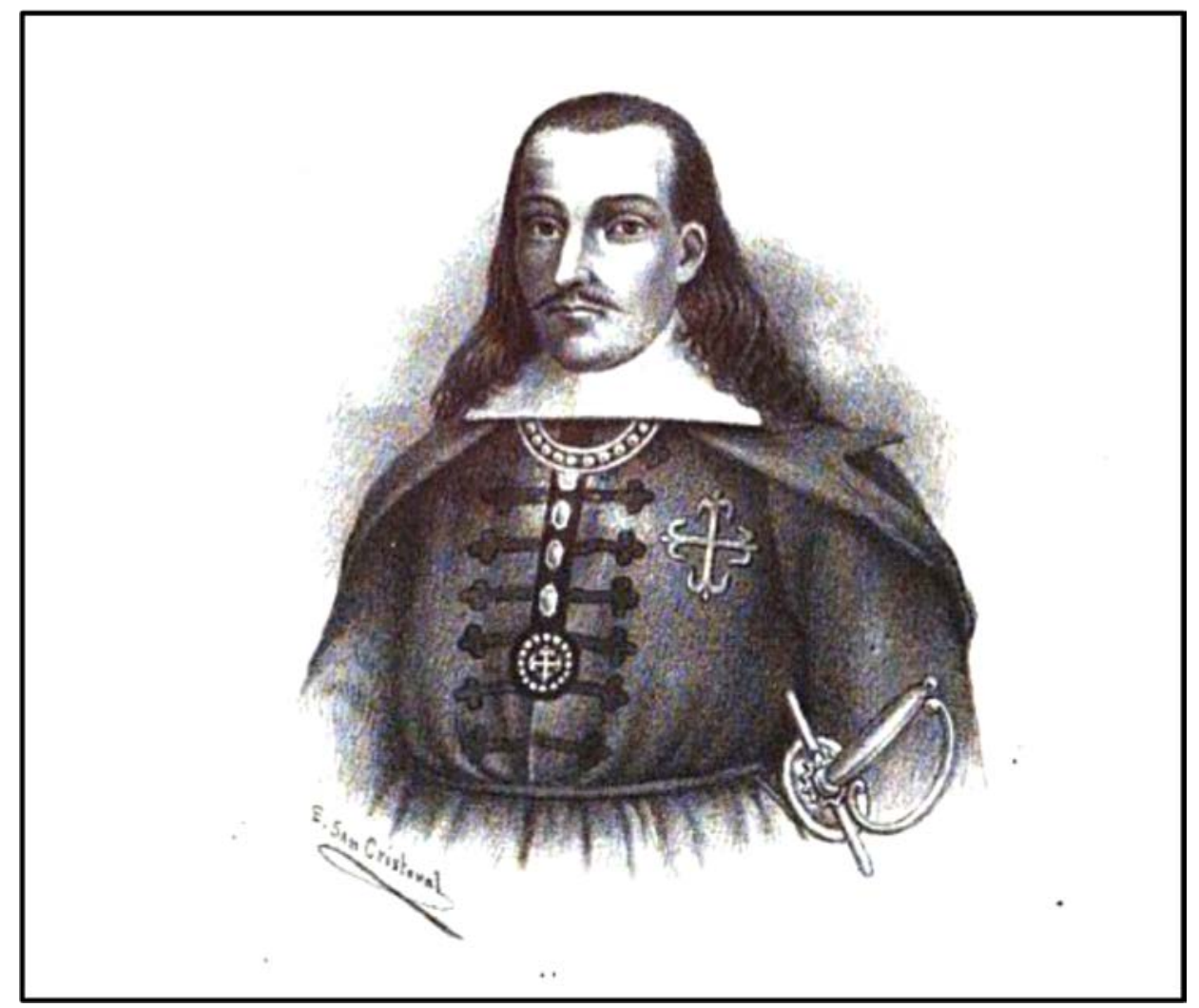

\footnotetext{
${ }^{134}$ Margaret Crahan “The Administration of Don Melchor de Navarra y Rocafull,” 389-412, points out that the greatest problems the Duke must face as viceroy of Peru were the invasion of pirates and the 1687 earthquake.
} 
Image 7: The Duke of Palata ${ }^{135}$

Analyzing how Lima's colonial government responded in the wake of this destructive quake facilitates an evaluation to its capacity of crisis management and, consequently, allows us to revise the cast of inefficiency that still pervades studies of the Spanish Hapsburg administration. Managing the aftermath of the 1687 quake in Lima was beyond the capacity of a single person. In order to tend to people’s basic needs and to safeguard the social order, the Viceroy gathered and led a contingent of royal officials to carry out the various tasks that the situation required. The active participation of the members of Lima's city council during the post-disaster period shows that these royal officers were able to effectively react under extraordinary circumstances. The vibrant, dynamic organizational capacity of the colonial government after the 1687 earthquake contradicts the pale portrait of an inefficient colonial administration.

The capacity of the colonial government to deal with this crisis, caused by a natural disaster in this case, undermines the notion of Spain's incapacity to rule. Whether or not one accepts the idea that Spain was in a long-term decline, there is scholarly consensus that the last two decades of the seventeenth century were tough for the Spanish

\footnotetext{
${ }^{135}$ Lavalle, Vivero, and San Cristóbal. Galería de Retratos de los Gobernadores y Virreyes del Perú, n.p.
} 
Hapsburgs. ${ }^{136}$ Although beginning in the 1980s several authors began to recognize that attempts to reform the imperial administration dated from the late seventeenth century and that many of these initiatives formed the foundation for further reforms during the eighteenth century, the idea of a steep drop in Spanish governance in the 1680s and 1690s persists. ${ }^{137}$ This is especially true in studies of the American colonies, which portray the colonial administration under Charles II as poor, corrupt, and lacking the means to impose the crown's will on corporate interests, which eventually forced every viceroy to compromise with the colonial subjects. ${ }^{138}$

\footnotetext{
${ }^{136}$ Lynch, Spain under the Habsburgs; John D. Bergamini, The Spanish Bourbons: The history of a tenacious dynasty (New York: Putman, 1974); José Manuel de Bernardo Ares, Luis XIV Rey de España. De los imperios plurinacionales a los estados unitarios, 1665-1714 (Madrid: Lustel, 2008).

${ }^{137}$ Henry Kamen, “The Decline of Spain: A Historical Myth?” Past \& Present, 81 (Nov. 1978), 24-50. Spain in the Later Seventeenth Century, 1665 - 1700. London: Longman, 1980; I.A.A. Thompson and Bartolomé Yun Casalilla, The Castilian Crisis of the Seventeenth Century (Cambridge: Cambridge University Press, 1994); Walker, Geoffrey, Spanish Politics and Imperial Trade, 1700 - 1789 (Bloomington, Indiana University Press, 1979); Lynch, Bourbon Spain, 1700 - 1808; Kuethe and Blaisdell. "French influence and the Origins of the Bourbon Colonial Reorganization,” 579-607; Geoffrey Parker, “La crisis mundial del siglo XVII: Acontecimientos y 'paradigma,'” in La crisis de la Monarquía de Felipe IV coordinated by Geoffrey Parker (Barcelona: Editorial Crítica, 2006), 19-54; and Luis Ribot, El Arte de Gobernar.
}

${ }^{138}$ Mark A. Burkholder, D. S. Chandler, From Impotence to Authority: The Spanish Crown and the American Audiencias - 1687-1808 (Columbia: University of Missouri Press, 1977) 16; Margarita Suarez, Desafíos Transatlánticos, 256. 
This chapter evaluates the performance of the colonial government in Lima vis-àvis the impact of the natural event. ${ }^{139}$ Recent studies of natural disasters demonstrate that the impact of these natural phenomena on human societies reveals social, economic and political patterns that otherwise remain unremarkable or hidden because they are so quotidian. ${ }^{140}$ A natural event is not necessarily a disaster; it becomes a disaster when it interacts with human societies’ vulnerability. ${ }^{141}$

${ }^{139}$ César Caviedes, El Niño in History. Storming through the Ages (Gainesville: University Press of Florida, 2001), 32, states that natural disasters have often influenced the course of history because of they frequently impact decisions of political and economic order.

${ }^{140}$ For the expansion in the study of natural disaster see David Alexander, "The Study of Natural Disasters, 1977-97: Some Reflections on a Changing Field of Knowledge,” Disasters 21, 4 (Dec 1997), 284 - 304. Andrew C. Isenberg, “Introduction: New Directions in Urban Environmental History,” in The Nature of Cities, ed. Andrew C. Isenberg (Rochester: University of Rochester Press, 2006), xi. Allen H. Barton, Communities in Disaster. A Sociological Analysis of Collective Stress Situations (Garden City, New York: Doubleday \& Company, 1969). William Kern, "Introduction,” in The Economics of Natural and Unnatural Disasters, edited by William Kern (Kalamazoo: W.E Upjohn Institute for Employment Research, 2010), 17, 1. Other definitions of disaster offered by economists are Alan L. Sorkin, Economic Aspects of Natural Hazards (Lexington: Lexington, 1982); Jack Hirshleifer, Economic Behavior in Adversity (Chicago: The University of Chicago Press, 1987)

${ }^{141}$ Richard Stuart Olson and Vicente T. Gawronski, "Disaster as Crisis Triggers for National Critical Junctures? The 1976 Guatemala Case,” Latin American Politics and Society 55, 2 (Summer, 2013), 133,134; Luz María Espinosa Cortés, “Oaxaca: Desastres, Hambre y Epidemias Entre los Pueblos ‘Criadores’ de Grana Cochinilla, 1760-1781,” in Cuba y México: Desastre, Alimentación y Salud. Siglos XVIII-XIX. Estudios de Caso, compiled by Luz María Espinosa Cortés and Enrique Beldarraín Chaple (Mexico D.F.: Plaza y Valdés, 2005), 142, states the worsening of a disaster is expressed through famine 
Earthquakes in particular are unpredictable geophysical hazards with intense magnitude, sudden occurrence, rapid onset, and variable geographical extent. ${ }^{142}$ This kind of natural disaster is prone to become a political crisis when the political system is disrupted and unable to tend to the increase in population's ordinary needs and the appearance of more complex demands. ${ }^{143}$ Despite the material and social impact seismic events have produced in human communities across the globe, historians have just recently began to recognize and analyze their influence on the development of human societies. ${ }^{144}$

and illness. The vulnerability of a specific population is determined by socio-economic, political, religious factors, and lack of prevention and mitigation measures of the disaster's impact.

${ }^{142}$ Sorkin, Economic Aspects of Natural Hazards, 2 - 4. Richard Stuart Olson, "Towards a Politics of Disasters: Losses, Values, Agendas, and Blame,” International Journal of Mass Emergencies and Disasters 18 (August 2000): 268, provides a division of five phases for earthquakes: pre-impact, impact, response, recovery and reconstruction. The recovery phase is the period when the fulfillment of basic needs is the prime objective. The reconstruction phase relates to the indefinite length period (days, weeks, months, years) when community rebuilds for a long-term. See also Allen H. Barton, Communities in Disaster; and Jack Hirshleifer, Economic Behavior in Adversity, 7.

${ }^{143}$ Olson, “Towards a Politics of Disasters,” 267.

${ }^{144}$ John C. Burnham, “A Neglected Field: The History of Natural Disasters,” Perspectives 26 (April, 1988), 22-24; James Penick, Jr., The New Madrid Earthquakes of 1811-1812 (Columbia: University of Missouri Press, 1976); Carl Henry Geschwind, California Earthquakes: Science, Risk, and the Politics of Hazard Mitigation (Baltimore: John Hopkins Press, 2001); John Dickie, “The Smell of Disaster: Social Collapse in the Aftermath of the Mesina-Regio Calabria Earthquake 1908," in Disastro! Disasters in Italy Since 1860: Culture, Politics, Society, edited by John Dickie, John Foot and Frank M. Snowden (New York: Palgrave, 2002, 235-255); Judith Chubbs, “Three Earthquakes: Political Response, Reconstruction, and the 
In Latin America, studies of natural disasters, specifically earthquakes, date back to the early twentieth century. Most of these works consist mainly of simple narrations of the events surrounding earthquakes in both the colonial and republican periods, compilation of contemporary witnesses’ accounts, or catalogs of primary sources. ${ }^{145}$ They contain abundant information for future research, yet most of them cover extensive chronological periods that do not allow deep historical analysis.

Institutions: Belice (1968), Friuli (1976), Campania (1980),” in Disastro! Disasters in Italy Since 1860: Culture, Politics, Society, edited by John Dickie, John Foot and Frank M. Snowden (New York: Palgrave, 2002), 186-233; Philip L. Fradkin, The Great Earthquake and Firestorms of 1906: How San Francisco Nearly Destroyed Itself (Berkeley: University of California Press, 2005); Gregory Clancey, Earthquake Nation: The Cultural Politics of Japanese Seismicity, 1868 -1930 (Berkeley: University of California Press, 2006)

${ }^{145}$ Manuel de Odriozola, Terremotos. Colección de las relaciones de los más notables que ha sufrido esta capital y que la han arruinado (Lima:Tipografía de Aurelio Alfaro, 1863); José Toribio Polo, Sinopsis de temblores y volcanes del Perú, siglos XVI-XIX (Lima:Librería e Imprenta de San Pedro, 1899); Julio Bustos Navarrete, Estudio Sismológico de Chile: con los temblores y terremotos producidos en los últimos cuatro siglos (Santiago: 1931); Pierre Saint, Observaciones e interpretaciones de los terremotos chilenos (Santiago: Universidad de Chile, 1961); Patricio Mans, Los terremotos chilenos, 2 vol. (Santiago: Ediciones Quimantú, 1972); Enrique Silgado Ferro, “Historia de los sismos más notables ocurridos en el Perú, 1513-1974,” Boletín del Institutio de Geología y Minería, 3 (1978); and Lizardo Siener Lizárraga, Estudios de historia medioambiental: Perú, XVI-XX (Lima: Universidad Ricardo Palma, 2002); Historia de los sismos en el Perú, and Historia de los sismos en el Perú: catálogo, siglos XVIII-XIX (Lima: Universidad de Lima, 2011). 
The works of non-Latin American authors have been path-breaking within a historiography that has grown in the last two decades. ${ }^{146}$ For the Peruvian case, most of these studies focus on the Earthquake of 1746 in Lima, which is considered the most devastating during the colonial period. ${ }^{147}$ Most authors analyze this natural event and its aftermath as providing the momentum that permitted political, social, and cultural transformation-the so-called Bourbon Reforms-- in the capital of the Peruvian viceroyalty. Pedro Pablo Pérez Mallaína’s and Charles Walker’s studies about the 1746

\footnotetext{
${ }^{146}$ Virginia García Acosta, Historia y desastres naturales en América Latina (Lima: Red de Estudios Sociales en Prevención de Desastres en América Latina, 1996); Susy Sánchez, “Un Cristo Moreno conquista Lima: los arquitectos de la fama pública del Señor de los Milagros 1651-1771,” in Etnicidad y Discriminación Racial en la Historia, edited by Scarlett O’Phelan, 65-92 (Lima: Fondo Editorial Pontificia Universidad Católica del Perú, Instituto Riva-Agüero, Banco Mundial, 2002); “La frágil ciudad de los conquistadores. Movimientos sísmicos en Lima,” in Lima XVI, edited by Laura Gutiérrez Arbulú, 457-489 (Lima: PUCP, 2005); Manuel Fernández Canque, Arica 1868: un tsunami y un terremoto (Santiago: Dirección de Bibliotecas, Archivos y Museos, 2007); Alfredo Palacio Roa, "Los terremoto, arquitectos por excelencia: Santiago de Chile 1730-1822,” (Master’s Thesis, Universidad de Chile, 2007); “Dominio y Catástrofe. Los terremotos en Concepción, Chile: 1550-1751,” Anuario de Estudios Hispanoamericanos, 69, 2 (2012), 569-600; Jaime Valenzuela, “El terremoto de 1647: Experiencia apocalíptica y representaciones religiosas en Santiago Colonial,” Historias urbanas. Homenaje a Armando de Ramón, edited by Jaime Valenzuela (Santiago: Ediciones Universidad Católica de Chile, 2007), 27 - 65; Juan Carlos Jurado Jurado, “Terremotos, pestes y calamidades. Del Castigo y la misericordia de Dios en la Nueva Granada (Siglos XVIII y XIX),” Revista de Historia Iberoamericana,4, 1(2011), 25-49.

${ }^{147}$ Francisco Quiroz Chueca, "Movimientos de tierra y de piso: el terremoto de 1746, la corrupción en el Callao y cambios borbónicos,” Investigaciones Sociales-Historia, 3, 4 (1999), 37-50; Susy Sánchez, “La ruina de Lima: mito y realidad del terrremoto de 1746 (Master’s Thesis: Pontificia Universidad Católica del Perú, 2001); Scarlett O’Phelan Godoy, “La moda francesa y el terrmoto de Lima de 1746,” Boletín del Instituto Francés de Estudios Andinos, 36, 1 (2007), 19-38.
} 
earthquake emphasize the absolutist reforms that Viceroy Manso de Velasco attempted in order to increase the colonial administration’s control over the Church and society. ${ }^{148}$ Pérez Mallaína focuses on the government's economic and political interests behind its postearthquake measures. Walker furthers this analysis and argues that the Viceroy's reforms were an early manifestation of the Bourbon reforms, which represented a new way of ruling. In these accounts, the reforms disrupted traditional and customary relationships between the colonial state and the royal subjects.

Similar to these contributions, studies on the Earthquake of 1755 in Lisbon demonstrate that absolutist state representatives used the crisis conjunctures produced by the natural events to introduce enlightened programs. Unlike Viceroy Manso de Velasco who had to abandon some of his initiatives and limited the implementation of others, the Marquis of Pombal, Secretary of State of Portugal, issued measures to improve the

\footnotetext{
${ }^{148}$ Pedro Emilio Pérez Mallaína, Retrato de una Ciudad en Crisis. La Sociedad Limeña ante el movimiento sísmico de 1746 (Lima: Pontificia Universidad Católica del Perú, 2001); Charles Walker, Shaky Colonialism: The 1746 Earthquake-Tsunami in Lima, Peru, and its Long Aftermath (Durham: Duke
} University Press, 2008). 
economic and political power of the Portuguese king, and also promoted the scientific justification of the natural event in order to undermine the power of the Church. ${ }^{149}$

Unlike the studies on these eighteenth-century natural disasters, this dissertation examines a trajectory of reform that did not follow but rather framed an earthquake. It examines events particularly during the earthquake's aftermath to evaluate the capacity of crisis management displayed by these royal agents. Certainly, it borrows some approaches from Pérez Mallaína’s and Walker's works, such as the treatment of the natural events as historical actors that expose the traditional antagonism between state and church. Yet this work concentrates on analyzing the nature of the Hapsburg colonial state and the foundational pillars that maintained it. Therefore, the Earthquake of 1687 is not the central subject of this dissertation, but rather a historical actor that both halted some of the ongoing reforms previously initiated, and finally permitted the rebuilding and consolidation of the early modern state in Lima.

\footnotetext{
${ }^{149}$ Mark Molesky, This Gulf of Fire: The Destruction of Lisbon, or Apocalypse in the Age of Science and Reason (New York: Alfred A. Knopf, 2015); José Luis Cardoso, “El Terremoto de Lisboa de 1755 y la política de regulación económica del Marqués de Pombal,” Historia y Política, 16 (2006), 209-236; Ana Cristina Araújo, “The Lisbon Eathquake of 1755. Public Distress and Political Propaganda,” E-Journal of Portuguese History 4, 1 (Summer, 2006), 1-11.
} 
This chapter focuses on the performance by leading royal officers in Lima, specifically the Viceroy and the members of the city council, in light of the material, social, and political turmoil that the earthquake produced, and the conditions of scarcity and disease that its aftermath brought. Ultimately, this chapter proposes that Lima possessed a strong and effective early modern government built on compromise and corporate cooperation. Until the eighteenth century, the rule of a monarch was not geared toward providing for the common good, but to achieve what was most "conveniente” for every part of the kingdom. ${ }^{150}$ Hence, a negotiating system was not inconsistent with this idea of government, nor did it denote ineffectiveness or decline.

The sources used in this chapter are mainly official records such as letter, accounts, testimonies, or meeting records. Despite the official character of these documents, it is possible to corroborate evidence contrasting one source against another. Testimonies and official accounts at times differed. Individuals that produced them, either by writing or through their verbal testimonies transcribed by a third party, offered different perspectives and information about the same events.

\footnotetext{
${ }^{150}$ Michel Foucault, “Governmentality,” 93.
} 


\section{The Terrible Night}

The Jesuit Fray Joseph de Buendía was placidly sleeping in his chamber at the Jesuit School of San Pablo when strong seismic movements forced him to seek refuge under the doorframe. Shortly after, his cell neighbor Fray Medina was by his side, frightened, and asking for confession. Both of them kneeled, cried, prayed, and absolved each other's faults. They remained heartbroken on their knees, waiting for a tragic end. As a last recourse, they raised their hands begging for divine assistance, an the earthquake suddenly stopped.

After recovering from the initial shock, both Jesuits, along with other members of their religious order, left the school in order to offer assistance to those who survived the strong quake. As soon as they reached the street, they witnessed a terrible scene of wanton destruction and death. The chaos was ubiquitous. Survivors were trying to rescue those who remained under the debris or recover the corpses of relatives and friends. The scenario was horrible. People were crying and begging for heaven's mercy but the earth continued shaking. ${ }^{151}$

\footnotetext{
151 Joseph de Buendía, “Relación del temblor que arruinó a Lima el 20 de octubre de 1687,” in Terremotos. Colección de las relaciones mas notables que ha sufrido esta capital y que la han arruinado, edited by Manuel de Odriozola (Lima: Tipografía de A.Alfaro, 1863), 24.
} 
The movement that woke up Fray Buendía was the first of two intense earthquakes that hit Lima on October 20. According to various descriptions of this event, the shaking started around four in the morning. ${ }^{152}$ Most of Lima's residents were sleeping when the first tremor started. As people tried to run away, chaos and confusion reigned. Fortunately, many were able to escape unscathed though, having the clothes they wore as their only remaining possession. ${ }^{153}$ This first tremor produced the collapse of some structures that crushed and trapped many people. Because of the intensity of this quake, people remained in the streets quivering in the cold, afraid of returning to their homes.

As soon as the commotion from this first shock waned, people began to assist the wounded and rescue the trapped, just as the Jesuits of the San Pablo School did. Suddenly, a second earthquake, more intense than the former one, struck the city again. It destroyed those buildings that remained standing after the previous quake. The ecclesiastical buildings suffered the greatest damage, and only a few did not completely collapse. ${ }^{154}$

\footnotetext{
${ }^{152}$ Letter from the Duke de la Palata to the King, December 8, 1687. BNM, MS. 9375.

${ }^{153}$ Relación del Ejemplar Castigo que envió Dios a la ciudad de Lima con los espantosos temblores de 20 de octubre de 1687. BNM, VE - 1461/1; Letter of Friar Domingo Alvarez de Toledo, Procurador General de Corte of the Order of San Francisco, from Lima, to the General Father of the same order, October 29, 1687. BNM MS. 9375, describe this first quake was followed by another strong, yet less intense tremor. Yet most accounts just indicated the first quake had a long duration.

${ }^{154}$ Luis Sifuentes, “Lima y los desastres sísmicos de 1687 y 1746” Demiurgo, 2 (2004), 111.
} 
The seismic movements also afflicted the port of Callao. A greater tragedy came from the sea just a few hours later when a tsunami hit the Peruvian littoral destroying Callao and the surrounding towns of fishermen Indians, Pitipiti y Quilcay. ${ }^{155}$ The power of the tsunami reached various port-towns on the coastline, producing inundations in towns such as Chancay, on the northern shore, and Pisco, Cañete, and Chincha, on the southern shore. ${ }^{156}$

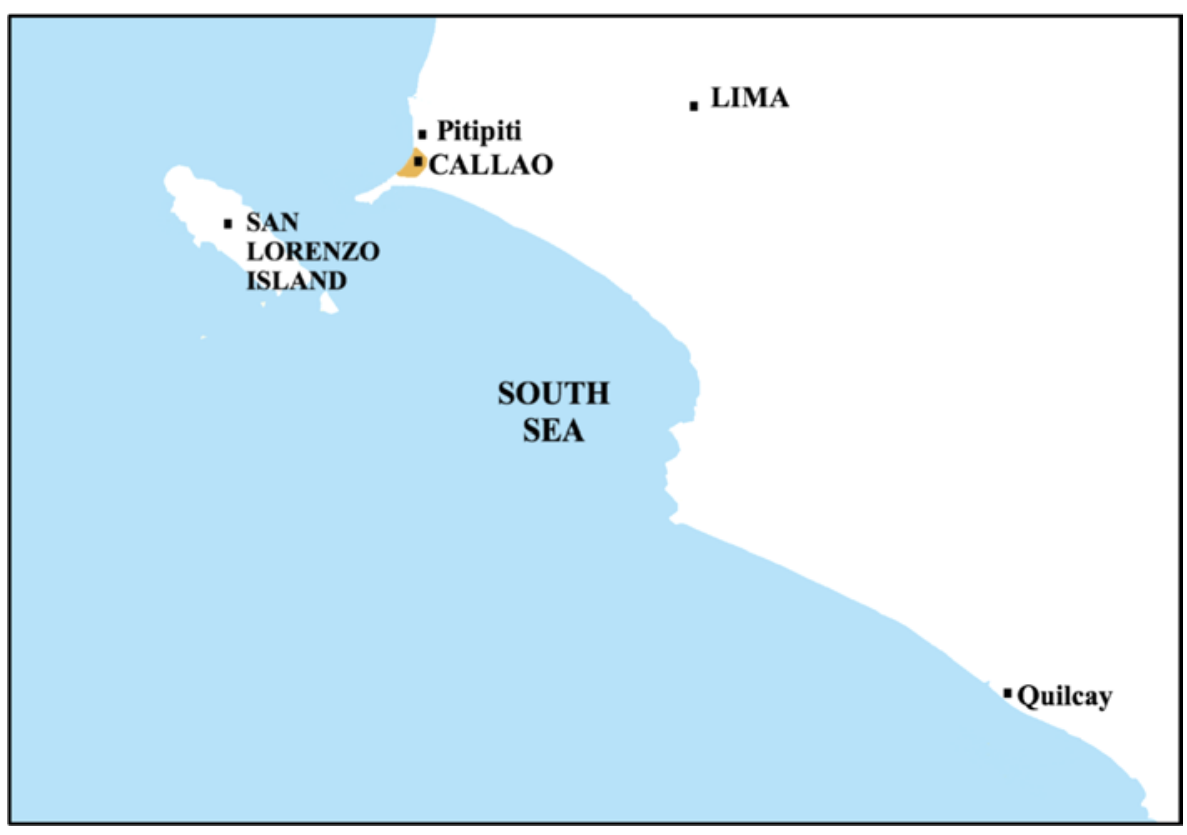

${ }^{155}$ The town of Pitipiti was located outside the walls of Callao, and Quilcay in Pachacamac, five leagues south of the port.

${ }^{156}$ Letter from the Duke de la Palata to the King, December 8, 1687. BNM, MS. 9375. 
Image 8: Indian settlements, Pitipiti and Quilcay, destroyed by the earthquake. ${ }^{157}$

At sunrise, Lima's residents realized the magnitude of the material destruction the earthquake produced. Almost all their religious buildings had collapsed, and many friars and nuns died inside their cloisters. The Chapel of Sagrario, located next to the archbishop's palace, was the only church that remained standing. Yet, it exhibited so many cracks that no one dared to enter it. ${ }^{158}$ The viceregal palace, home of the viceroy and headquarter of various branches of government, was completely destroyed. The portals of the Plaza Mayor and the City Hall were also in ruins.

\footnotetext{
${ }^{157}$ Map made by the author.

${ }^{158}$ Account of the City Council, f. 9 v.
} 


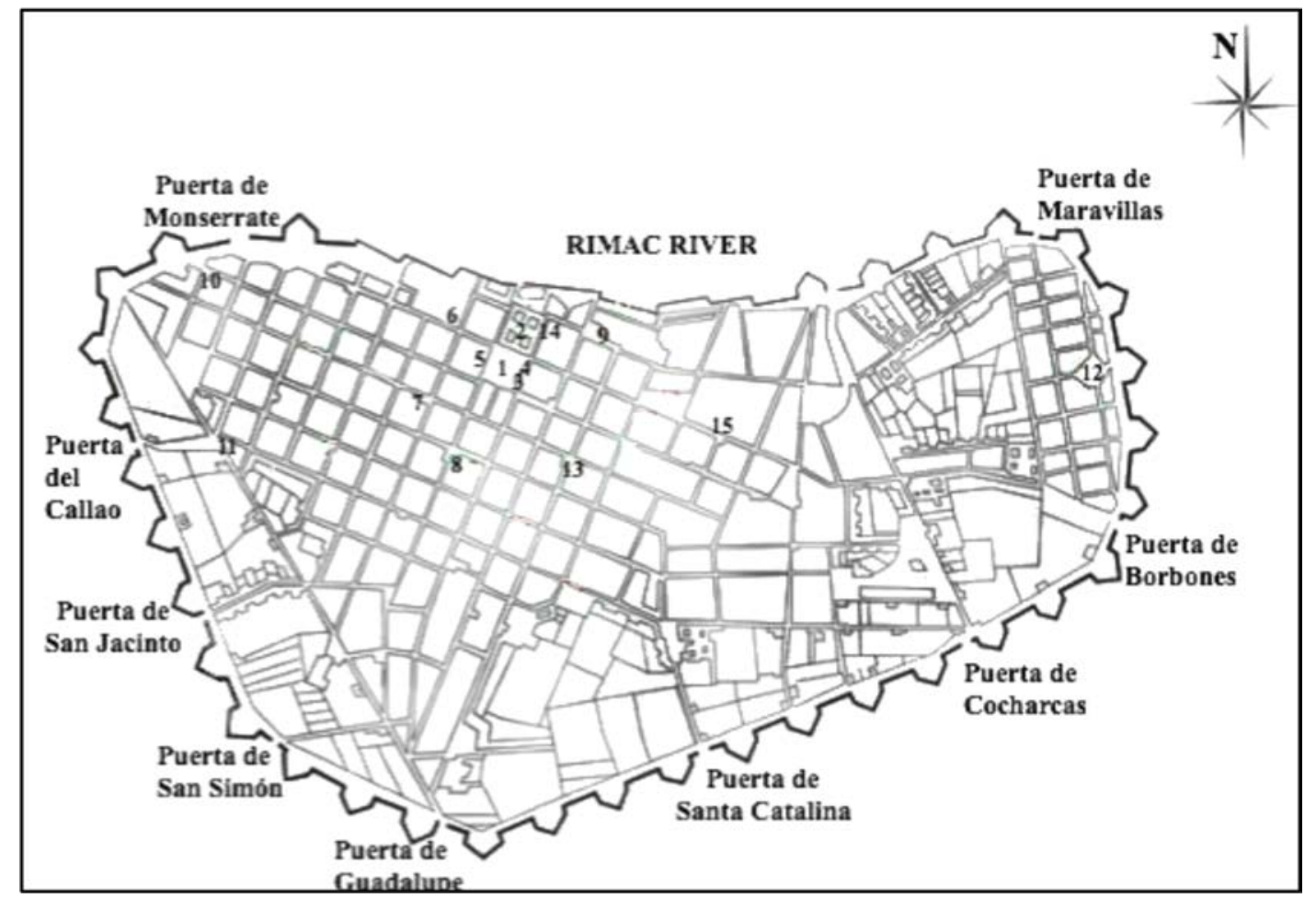

Image 9: Lima’s main buildings and plazas. 1. Plaza Mayor, 2. Viceregal Palace, 3. Cathedral, 4. Sagrario Chapel, 5. City Hall, 6. San Agustín Convent, 7. Santo Domingo Convent, 8. La Merced Convent, 9. San Francisco Convent, 10. Monserrate Church, 11. San Francisco de Paula Hospice, 12. Plaza del Cercado, 13. San Pablo School and Society of Jesus Church, 14. Alhóndiga, and 15. Casa de la Moneda. ${ }^{159}$

Many private buildings suffered damage, but to a lesser degree than those of the Church and the colonial administration. Nonetheless, people refused to return to their permanent residences. They feared that the remaining structures could fall down anytime, so they looked for alternative places for shelter. They erected temporary dwellings in open

\footnotetext{
159 Map made by the author using Rolando Arciga. Plano de Lima donde se ve la ubicación de las puertas que tenía la muralla, "La Muralla De La Ciudad De Lima". Blog. Arqueología Colonial, 2012. http://arqueologiacolonial.blogspot.com/2012_01_01_archive.html.
} 
spaces, away from the crumbling structures. ${ }^{160}$ Even religious men and women had to abandon their cloisters to find refuge in gardens, plazas, and empty lots.

The first place limeños occupied was the Plaza Mayor, the political and symbolic center of the city. Even the Viceroy and his family had to live there for a few months. Most people, both lay and religious, spread throughout the city and its outskirts. Some fortunate religious congregations were able to build temporal adobe structures on land within their property. For instance, the San Agustín and Santo Domingo friars moved to the gardens of their convents. Similarly, the religious of the Convent of Merced relocated within a plot, called Belen, which belonged to their order. ${ }^{161}$

Elite residents were also able to find protection in open spaces within their own property, which also harbored people from diverse social conditions that sought shelter. For instance, outside the southern section of the city wall, in the yard named San Jacinto, property of Antonio Jiménez, people built temporary dwellings of different materials such as wood, mats, reeds, and straws. They even erected a school for children and two chapels that some priests tended. Close to Monserrate Church, on the eastern side of the city, in

\footnotetext{
${ }^{160}$ Letter of the Duke of the Palata to the King, Lima, December 8, 1987. BNM, MS 9375.

${ }^{161}$ Relación del temblor que sucedió en Lima lunes 20 de octubre de 1687; Account of the City Council, f. $5,6$.
} 
another yard called El Cuero, property of Don Juan de Aliaga, many families constructed several chambers and a chapel among the trees. Similarly, people occupied many other private gardens, yards, and vacant lots around the city, inside or outside its walls. ${ }^{162}$

Lima’s population filled every available space without regard for social division. People of both genders arrived at the yard of the San Francisco de Paula Hospice. Because the chapel, cells, and rooms belonging to this institution were destroyed, the religious living at the hospice moved to the yard. During his inspection of the city, notary Diego Fernández Montaño was surprised to find out that religious men were sharing the same space with lay people of both genders. ${ }^{163}$ The royal officer was also astonished to find a majority of Spaniard families located at the main square of the Indian town of El Cercado, adjacent to Lima. ${ }^{164}$ The spreading of the population and the mingling of social groups alarmed the royal authorities.

The large amount of debris on the streets and the fetid odor of corpses accentuated the rampant disorder. Despite the efforts to rescue people from the rubble, many corpses

\footnotetext{
${ }^{162}$ Account of the City Council, f. 6v - 7 .

${ }^{163}$ Ibíd., f. 5

${ }^{164}$ Ibíd., f. 8.
} 
remained buried. Some contemporary witnesses recalled that among those rescued from the debris, there were some already dead and others alive. A few of the latter were unscathed, yet many others had wounds. Those severely injured received spiritual assistance rather than medical treatment. Royal authorities calculated the death toll between 300 and $400 .{ }^{165}$ This amount represented a small fraction of the whole population of Lima, which ascended to around 32,000 people. ${ }^{166}$ Regardless of the accuracy of this official amount, contemporary witnesses lamented only the loss of influential people, such as Don Alvaro Ponce de León, who died suffocated by dust; General Don Juan Ramirez de Arellano, his wife Doña Ines de Rivera, and their son Nicolás, who died when a wall from their home collapsed on top of them; and oidores Don Diego de la Rocha, Don Alonso del Castillo, and Don Diego Portales. ${ }^{167}$

${ }^{165}$ Letter from the Duke de la Palata to the King, December 8, 1687. BNM, MS. 9375.; Account of the City Council, f. 1

${ }^{166}$ María Pilar Pérez Cantó, “La Población de Lima en el siglo XVIII,’ Boletín Americanista, 32 (1982), 384, 390, provides a figure of 34,724 people in Lima by 1700 . She bases her estimate on the accounts made under the orders of Viceroy Marquis of Salinas in 1600, Viceroy Marquis of Montesclaros in 1613, and Viceroy Count of Monclova in 1700.

${ }^{167}$ Memorial Ajustado y Resumen de los actuado en la residencia del Dr. Virrey Duque de la Palata, November 3, 1690. AGI, Lima, 87, f. 18; Buendía, Relación del temblor que arruinó a Lima el 20 de octubre de 1687; Letter from the Duke de la Palata to the King, December 8, 1687. BNM, MS. 9375, refers the amount of deaths among people "de cuenta" ascended only to 6. Letter from the Viceroy to the King, May 3, 1688. AGI, Lima, 87. 
The government met compounding challenges trying to rule and control a dispersed and dispossessed population. The new configuration of the city, with so many small settlements across the city and its surrounding areas, also altered the ordinary means of food distribution. Scarcity and hunger became part of quotidian life in the months following the quake. Disease soon struck survivors' debilitated bodies.

Describing the general feeling of the population, Dominican priest Fray Domingo Alvarez said, "Today [Lima] cries, miserable [in] her ruin, all her greatness and buildings obliterated by the soil." 168 The condition of the city was critical. The cleaning, ordering, and rebuilding activities demanded arduous and backbreaking labor. The population also required basic provisions of food and water in order to survive. All these tasks represented a grueling trial for the colonial government.

\section{Tending to Temporal Necessities}

As head of the colonial government, Duke of La Palata assumed the responsibility of reconstructing and reorganizing the city. He rapidly mobilized the members of the city council in order to organize the administration of the city under the new critical

\footnotetext{
168 Letter of Friar Domingo Alvarez de Toledo, Procurador General de Corte of the Order of San Francisco, from Lima, to the General Father of the same order, October 29, 1687. BNM, MS. 9375.
} 
circumstances. He assumed leadership roles in the activities of temporal assistance and reconstruction, as well as in religious matters because of the prolonged absence of the spiritual shepherd from the city, Archbishop Liñán y Cisneros. In the following months after the quake, the dispersal of population and the new precarious living conditions generated a favorable setting for the outbreak of diseases, which took a toll greater than the earthquake itself. Rather than signs of failure, these circumstances were challenges the administration could not avoid and had to overcome.

During the night of the disastrous event, the Duke and his family abandoned the viceregal palace when the first quake hit. Once at the Plaza Mayor, the Viceroy left his family and went to assist those trapped under the rubble who were clamoring for help. ${ }^{169}$ He was busy digging out the survivors when the second tremor produced the collapse of many more buildings. He recalled his greatest fear "was that of the earth I stepped on, because it did as sea waves, that I could not stand on, and kneeling, to die, was unable to maintain myself on the ground." ${ }^{170}$ As soon as this second quake was over, he took the first measures to deal with the critical conditions of the city.

\footnotetext{
169 Testimony of Pedro Fernández de Valdez, master builder, Account of the City Council, f. 30v.

${ }^{170}$ Letter from the Duke of the Palata to the King, December 8, 1687. BNM, MS 9375, "me parecio el de la tierra que pisava pues haziendo olas como el mar no me podia tener en pie y arrodillado, ya para morir, tampoco me podia mantener en el suelo.”
} 
One of his first decisions was to establish his provisional lodging at the heart of the city or Plaza Mayor. The Duke had to accommodate himself and his family in a humble cabin erected at the plaza to lodge them. Despite the poor condition of this new dwelling, the Duke believed that it provided a strategic and central place to perform his governmental duties. The Viceroy recalled he "did not want to stay away from the center of the city downtown, as it seemed to me [the viceroy] it would be a huge grief for everyone to see their viceroy departing from them; and of much inconvenience any distance for the prompt and extraordinary actions with which now it has to be ruled, because there are no courts.”171 He realized that his behavior would set an example for the population, so he resolved to act with strength and determination to instill in others the same confidence. For the Duke, the service for the people and the crown came before his personal interests.

The destruction of the viceregal palace meant that various branches of the royal administration lost their traditional space to discuss governing matters. The Real Audiencia, Court of Crime, Tribunal of Accounts, and Treasury suspended their meetings

\footnotetext{
${ }^{171}$ Ibid, "no he querido apartarme del centro de la ciudad pareciendome que seria gran desconsuelo para todos el ver que se les alejase su virrey, y de mucho embarazo cualquier distancia para los promptos y extraordinarios espedientes con que agora se ha de governor, pues no ay tribunales.”
} 
for some months because their members lacked appropriate places to meet. ${ }^{172}$ In addition, many ministers were unable to tend to their administrative duties because they were providing for their families' necessities or recovering from injuries. Two high court judges, Don Diego de la Rocha and Don Diego Portales, died in the quake. For this reason, the number of ministers available to participate in the Real Acuerdo, or viceroy’s counseling body, decreased to three active members. ${ }^{173}$

A few months later, after the Viceroy and his family abandoned the makeshift rooms they lived in at the Plaza Mayor, the tribunals finally resumed their activities in the new available spaces. Nonetheless, the Viceroy did not suspend the tasks of his administration, as many branches of the government did, during months of the aftermath. He summoned the members of the city council, which continued actively working under his orders.

Studies of this corporative body portray it as an institution more emblematic than pragmatic. However, after the quake its members played important roles during the recovery and reconstruction period. Scholars criticize the sumptuous expenses of the

\footnotetext{
${ }^{172}$ Account of the City Council, f. 2.

${ }^{173}$ Memorial Ajustado y Resumen de residencia, f. 18;
} 
colonial cabildos to organize ceremonies to celebrate the entrance of a new viceroy and important royal events, such as the birth of a prince or military victories. ${ }^{174}$ The expenses for ceremonial activities account for the shortages of the cabildos' budgets. ${ }^{175}$ Nonetheless, city councils had many other functions that were more ordinary, such as the provision of food, the regulation of prices, and control of social order. The Earthquake of 1687 offers the opportunity to closely examine those other regular activities altered during the disaster.

Two days after the earthquake, the Viceroy held his first official meeting with the members of the city council. On this occasion, the counselors and the Duke reviewed the city council's records for the year 1586, when another earthquake hit the city, in order to issue the necessary measures to reorganize the city. In this meeting, the Viceroy named two provisional alcaldes to assist the two officers that already occupied this post. ${ }^{176}$ The

\footnotetext{
${ }^{174}$ Pablo Emilio Pérez-Mallaína, “Le pouvoir de l'etat les forces de la nature: la reconstruction de Lima apres le tremblement de terre de 1687," in De Séville a Lima, edited by Alain Musset and Pablo Pérez Mallaína (Paris: Université de Paris X - Nanterre, Laboratoire de Géographie Urbaine, 1997), 171-174.

175 Peter Bakewell, A History of Latin America (Oxford: Blackwell Publishers, 1997), 123.

176 Jay Kinsbruner, The Colonial Spanish-American City. Urban Life in the Age of Atlantic Capitalism (Austin: University of Texas Press, 2005), 34; John Preston Moore, The Cabildo in Peru under the Hapsburgs: A Study in the Origins and Power of the Town Council in the Viceroyalty of Peru, 1530 - 1700 (Durham: Duke University Press, 1954), 145. Actas del Cabildo de Lima, Libro 31, Archivo Histórico de la Municipalidad Metropolitana de Lima (hereafter AHMML), f. 157v-158. The number of alcaldes ordinarios in the city council was traditionally two. The Viceroy duplicated the number as a measure to expedite the traditional activities of these officers.
} 
purpose of this measure was to improve the city council's efforts to distribute food and control the social order, which became difficult because of the dispersion of people throughout and beyond the city.

For royal administrators, the chaos and disorder converted the city in a propitious place for robbery or other illicit practices of lower groups. Except for two instances, which occurred outside the city, sources remain silent about criminal activity in Lima. ${ }^{177}$ Without denying that the conditions of the city offered good possibilities for illicit behavior, authorities' negative perception of the lower groups, especially of non-whites , drove their interest to accentuate social control and security in the city.

The Viceroy was also concerned that crumbling building structures might unexpectedly collapse on top of pedestrians. In the following days, the Duke appointed

\footnotetext{
${ }^{177}$ Request by Vizente de la Rocha before the Ecclesiastical Court, Archivo General de la Nación (hereafter AGN), Tribunal Eclesiástico, Censuras, L.3, D.245, F.1., s/f. De la Rocha had a storage in Callao, where he stored various merchandise. During the quake, the property collapsed killing the guardian. De la Rocha declared that some of the merchandise, along with his accounting book, were stolen. For that reason, he requested the Vicario General to issue some censuras (admonishments) to obtain information about the stolen goods. Letter from Francisco de Colmenares, treasurer of the royal treasury, to Visitor Juan de Peñalosa, May 8, 1688. AGI, Lima,289. Treasurer Colmenares informed Visitor Peñalosa that some jars of quicksilver were stolen from the royal warehouse at the port of Chincha. The guardian of the storage followed the trail left by the quicksilver and arrested a black man accused by the port butcher. He also stated that a few days later the guardian priest of Santo Domingo brought two jars of quicksilver to the royal warehouse that he received in confession.
} 
seven commissioners (comisarios) to assess the damage of the buildings located on the principal streets. These officers had to explore the entire city, along with a construction master (alarife), to identify the structures that were prone to collapse, so that, according to the Viceroy's orders, they could be demolished. He realized the gravity of the damage these buildings could generate if they finally collapsed.

Colonial administrators tried to control the inflation of wages and building supplies, which would have increased because of the urgencies of reconstructing property. The Duke fixed the salary of construction masters and laborers (alarifes, barretones, and peones) to limit the increasing wages these workers began to request. ${ }^{178}$ The Viceroy attempted to control these wages because they would overburden private owners and tenants, who had to assume the unexpected expenses of reconstructing their properties. ${ }^{179}$ The different measures implemented by Duke during the earthquake's aftermath show he aimed to govern in a balanced way.

\footnotetext{
${ }^{178}$ Ibid, 154, the Viceroy established the following wages: alarifes, 3 pesos; barreteros, 1 peso; and peones, 6 reales; 176, the counselors also set the compensation of bricklayers at 14 pesos, and adobe-layers at 10 pesos per day. Adobe-makers would earn 12 pesos per thousand adobes.

${ }^{179}$ Actas del Cabildo de Lima, 157r. - 159 r.
} 
In the following months, the city council followed the same policy of fixing the prices of certain construction materials: the cahíz of cal at 12 pesos, a thousand bricks at 22 pesos, a thousand large adobe blocks at 34 pesos, and a thousand small ones at 32 pesos. Counselors ordered this measure because these products became essential and of great demand during the period of reconstruction. If someone was caught reselling construction materials, the council would confiscate them, assigning two-thirds of the product towards the rebuilding of the city hall and the remaining to compensate the informer who alerted the body of the illegal sales. ${ }^{180}$

The city council also ruled that those laborers who demanded excessive salaries would be condemned to work for one month without compensation on the reconstruction of the City Hall building and its jail. ${ }^{181}$ In addition, counselors prohibited natives from being put to work on reconstruction activities because they were more useful working their land than in the city. ${ }^{182}$ This concern about maintaining Indians in the fields responded to the necessity of supplying enough food for Lima’s people.

\footnotetext{
${ }^{180}$ Ibid, f. 175 v.

${ }^{181}$ Ibid, f. 171.

${ }^{182}$ Ibid, f. 183 v.
} 
The provision of food was among the customary duties of the city council, yet it became a priority after the earthquake in order to battle the waves of disease and hunger that spread very quickly. ${ }^{183}$ The precarious condition of the temporary dwellings exposed people to the nocturnal cold and the diurnal heat, creating a propitious environment for the eruption of diseases. ${ }^{184}$ Just a few days after the quake, the city council reported outbreaks of "sudden diseases" among the population. ${ }^{185}$ The following months of late spring and summer brought more discomfort, and hunger accentuated the weather’s harshness. ${ }^{186}$

Counselors were afraid of food shortages. One of their main concerns was to procure the supply of lamb and beef. They ordered the providers to secure enough of these products. They also agreed to closely supervise the activities of the suppliers, register their herds and fields, and fine them if they failed to offer enough meat. ${ }^{187}$ The provision of bread and water had also diminished because the earthquake had buried all the bakeries

\footnotetext{
${ }^{183}$ Moore, The Cabildo in Peru under the Hapsburgs, 170.

${ }^{184}$ Letter from the Duke de la Palata to the King, December 8, 1987. BNM, MS. 9375.

185 Actas del Cabildo de Lima, f. 158.

${ }^{186}$ Relación del Temblor que sucedió en Lima lunes 20 de octubre de 1687. BNM, MS. 18760/36

${ }^{187}$ Actas del Cabildo de Lima, f. 155.
} 
and inundated the ditches of the city. ${ }^{188}$ For that reason, the city council instructed the alcalde ordinario Don Diego de Manrique to request testimony from all bakers in the city. Manrique had to inquire if they had any wheat in their possession, what quantities, and how they obtained it. ${ }^{189}$ The purpose of this investigation was to uncover possible suppliers that might be selling overpriced wheat.

The counselors were also concerned that the shortage of food and the disruption of common methods of supply would increase the price of the most sought-after food products. The dispersion of people throughout the city also obstructed the activities of food distribution. In addition to controlling the provision of basic food products, such as meat, wheat, and tallow, ${ }^{190}$ the royal officers fixed some prices. For instance, they established the price of fat at 5 pesos per arroba, tallow at 5 pesos 4 reales, and wheat at 4 pesos 4 reales. $^{191}$

\footnotetext{
${ }^{188}$ Relación del Ejemplar Castigo que envió Dios.

189 Actas del Cabildo de Lima, 154 v - 155.

${ }^{190}$ Ibid, $158 \mathrm{v}-159,161 \mathrm{v}$.

${ }^{191} \mathrm{Ibid}, 156 \mathrm{v}, 170,178 \mathrm{v}, 185 \mathrm{v}$; a few months later, the city counselors noticed the increase of construction workers' salaries and materials' price. Therefore, they commissioned Don Alonso Laso de la Vega the enforcement of the orders and the application of fines previously issued to limit such excesses.
} 
This increased concern to protect Lima's food provisions became evident in the counselors' close supervision of the transactions of goods and services. The constant inspection of suppliers' pens, cattle, and products resulted in prosecutions and fines. The first of these incidents involved the lamb supplier, Alonso Sánchez de Bustamante. In 1685, the city council had contracted Bustamante to provide meat for six years. In exchange, Bustamante offered to pay 80,000 pesos to obtain this exclusive right. The royal officers assigned this money to fund the construction of the city wall. ${ }^{192}$ Three months later, after the quake, the counselors noticed the amount and quality of meat that Bustamante was selling had declined. After a rapid investigation, they confirmed that Bustamante was offering poor-quality meat, "bad and thin." 193 The council's members punished this supplier with the reduction of his selling price. Additionally, in order to increase the provision of meat, the counselors allowed any person to sell meat at a higher price than

\footnotetext{
${ }^{192}$ Mendiburu, Diccionario Histórico - Biográfico del Perú, vol. 8, 94; Melchor de Navarra y Rocafull, “Memoria de Gobierno,” 383.

${ }^{193}$ Actas del Cabildo, f. 176v - 177v. The alcalde ordinario, Don Rodrigo de Mendoza Ladrón de Guevara, and a regidor, Don Diego Manrique de Lara, went to the fields where Bustamante kept the cattle to find out if there were the necessary herds to provide enough meat for the city. Additionally, the Real Acuerdo penalized Bustamante with a fine of 6,000 pesos. For that reason, the council did not impose on him another fine.
} 
permitted to Bustamante. ${ }^{194}$ They cut into the exclusive concession of Bustamante trying to both compensate the consumers and penalize the lamb supplier. The cabildo also punished the supplier of fat, Captain Roque Falcón, with 4,000 pesos for distributing very liquid fat, and levied a fine of 1,000 pesos on beef provider, Pedro Pasqual del Valle, for selling poor quality meat. ${ }^{195}$

Despite the measures to provide enough food for Lima's residents, the summer months took their toll. In March, a plague of typhus fever (tabardillo) and tertian fever (tercianas) ravaged the city. ${ }^{196}$ The physicians calculated that around 14,000 people got sick with "fevers and sudden pains", and approximately 2,600 had died. ${ }^{197}$ The disorganized dispersion of the people and the short number of physicians hindered the

\footnotetext{
${ }^{194}$ Ibid, 178v. The council limited the sale price of the supplier's meat to $2 \frac{1}{2} 2$ pesos the quarter of a sheep; other individuals could sell meat at 3 pesos the same quantity of meat.

${ }^{195}$ Ibid, f. 178 - 179. Falcón was unable to continue providing tallow in the quantity and quality the city council demanded. Only two weeks later he requested authorization to limit the sale of tallow to only one pound per family, and to leave his obligation as official supplier at the end of his term; 180, Pasqual del Valle appealed the fine, yet the council rejected his petition arguing he had not complied with most of the clauses of the contract where he received the monopoly to sell beef.
}

${ }^{196}$ Ibid, f. 186.

${ }^{197}$ Account of the City Council, f. 3v. Tabardillo was the common name for typhus. Tercianas were fevers, symptomatic of malaria, which appeared every three days. 
provision of medical attention to the sick. ${ }^{198}$ In fact, the death toll from the plague was higher than the estimated 400 casualties from the quake. Even though the administration took measures to tend the population's need, the combination of scarcity and poor living conditions undermined people’s resistance to disease.

Nevertheless, it is evident the counselors improved the performance of their duties. The Viceroy's close supervision tightened the operation of the city council. The Duke was able to organize his subalterns to tend the increasing needs of the population. The cabildo's increased control and surveillance of food suppliers demonstrated that its members had the capacity to at least try to deal with critical conditions. Royal officers took steps to quickly organize and develop means to deal with the critical conditions of the city. Together, the Viceroy and other royal officers established measures oriented to provide appropriate solutions to the demands created during the chaotic post- disaster period.

\section{Spanish Empire’s Bureaucracy}

The dynamic interplay of imperial and local government became apparent in the joint response by the Viceroy and the city council to the earthquake. To examine the dynamics of imperial rule, it is necessary to set the metropolis and the colony on the same

\footnotetext{
${ }^{198}$ Letter from the Viceroy to the King, April 21 1688. AGI Lima, 87, indicates four physicians died in the quake, and three got sick.
} 
analytical ground, and observe the interconnection and reciprocal processes of shaping ideas, knowledge, and practices in the post-disaster period. These interactions-made visible after the Earthquake of 1687-- reveal the logic behind early modern government.

In the months following the quake, the Viceroy and the city council implemented various measures and issued new rules targeted to provide the "right thing"—government services or recognition-- to each part of the society. This "right thing" was far from a common good for the entire society. For early modern rulers, the art of government consisted of providing what was most appropriate, according to social standing, to each part of society. ${ }^{199}$ The Duke attempted to provide each group he ruled (proprietors, laborers, food supplies, royal officers, etc.) the most appropriate provisions. The city council understood and followed suit, and applied the logic of early modern governance through the rules it created and the penalties it imposed during the reconstruction period.

The performance of the Viceroy during the aftermath of the earthquake reflects the practices of imperial rule in a Spanish colony. The Duke de la Palata was the representative of the Spanish king and, consequently, embodied the legitimacy of the imperial government in its colonies. At the same time, he was part of a growing bureaucracy that

\footnotetext{
${ }^{199}$ Foucault, “Governmentality,” 95
} 
the Spanish crown instituted with the purpose of improving the administration of both the metropolis and the colonies.

The expansiveness of the Spanish empire meant various and different kinds of natural disasters afflicted diverse parts or kingdoms. Some disasters, such as disease or famine, were common in pre-modern times, regardless of the geographic area. Others natural events such as hurricanes and earthquakes affected only specific areas. Nevertheless, during the seventeenth century in Europe, the "little Ice Age” had produced lower-than-average temperatures during the previous century, resulting in weak harvests. The constant wars that spread throughout Europe accentuated scarcity and made people prone to contact a disease. Climate change also produced an increasing telluric activity around the "ring of fire" in the Pacific Ocean. ${ }^{200}$

During the government of Charles II, a prolonged wave of disasters such as bad harvests, food shortage, and epidemics affected Castile from 1677 to 1686 . Epidemics of fever and flu (catarro) started in 1672, and became a plague in 1676, with several outbreaks until 1682. Another epidemic hit immediately and lasted until 1685. ${ }^{201}$ Terrible harvests

\footnotetext{
${ }^{200}$ Geoffrey Parker, Global Crisis. War, 3-76. The "ring of fire” is a string around the edges of the Pacific Ocean, with large seismic activity.

${ }^{201}$ Henry Kamen, Spain in the Later Seventeenth Century, 1665 - 1700 (London: Longman, 1980 ), 46 - 54.
} 
of 1665-68, and 1677-83 aggravated the situation. ${ }^{202}$ Floods in 1680 and 1681, and droughts in 1682 and 1683, produced a food shortages, causing famine in the entire peninsula. ${ }^{203}$ Earthquakes hit several other parts of the empire: the province of Cumaná in Santo Domingo, during the night of May 4, 1684, the provinces of Riobamba, Tacunga, Ambato, and Patata in Ecuador, on June 20, 1698. ${ }^{204}$ In Europe, the city of Naples and the Calabria region also suffered a terrible earthquake on June 5, 1688.

News of the different disasters reached the metropolis, where royal administrators began to develop a certain familiarity with them and issued measures accordingly. ${ }^{205}$ The expansiveness of the empire promoted the dissemination of such knowledge. In the various years that the Duke occupied high administrative posts in the metropolis, Castile had suffered a prolonged wave of disasters. It is possible that during the years he served the Spanish crown in the Old World, the Duke of Palata developed the knowledge and capacity

202 Parker, Global Crisis, 286.

${ }^{203}$ Henry Kamen, Spain, 1469 - 1714. A Society of Conflict (London: Pearson, 2005), 283; Kamen, Spain in the Later Seventeenth Century, 46 - 54. States a prolonged wave of disasters such as bad harvests, food shortage and epidemics affected the Castilians from 1677 until 1686.

${ }^{204}$ AGI, Santo Domingo, 188, R. 2, N. 25; AGI, Diversos - Colecciones, 27, N. 58.

${ }^{205}$ AGI, Codices, L. 752, imagen 141. In 1673, the Council of Indies provided limosnas and mercedes to reconstruct the temples and Fortresses of Santo Domingo, which devastated by an earthquake. 
to deal with critical conditions. ${ }^{206}$ Compounded with a strong leadership personality, he seemed a perfect public servant to deal with the 1687 Lima disaster.

As mentioned above, witnesses recalled the Duke personally participated in the rescue of people trapped under the debris. He rapidly made strategic decisions, such as when he preferred to occupy a reed cottage in the Plaza Mayor, from where he could supervise the administration of the city, rather than move to a better accommodation outside of Lima. He gathered the city counselors and took the measures necessary to tend to the most needy. Father Buendía recounted the Duke gave alms from his own money to the people. ${ }^{207}$ Another witness praised the devotion of the Viceroy, who led various processions with the purpose of mitigating God's wrath. ${ }^{208}$ Most of the contemporary

\footnotetext{
${ }^{206}$ Noble David Cook and Alexandra Parma Cook, The plague files: crisis management in sixteenthcentury Seville (Baton Rouge: Louisiana State University Press, 2009); Charles Walker, "Shaking the Unstable empire: The Lima, Quito, and Arequipa Earthquakes, 1746, 1783, 1797,” in Dreadful visitations: confronting natural catastrophe in the age of Enlightenment, edited by Alessa Johns (New York: Routledge, 1999), 113 - 144; Stephen Tobriner, "Safety and Reconstruction of Noto after the Sicilian Earthquake of 1693 - the eighteenth Century Context,” Dreadful Visitations, 49 - 77; and Sherry Johnson, "The St. Augustine Hurricane of 1811: Disaster and the Question of Political Unrest on the Florida Frontier,” The Florida Historical Quarterly 84, No. 1, Special H-Florida Issue: Florida History from Transnational Perspectives (Summer, 2005), 28-56, offer diverse examples of royal officers that provided effective measures of relief in pre - modern times.

${ }^{207}$ Relación del temblor que arruinó a Lima el 20 de octubre de 1687, 29.

${ }^{208}$ Relación del Ejemplar Castigo que envió Dios a la ciudad de Lima.
} 
sources mentioned the active performance of the Viceroy during the months after the quake in both political and religious matters.

He was emblematic of the Spanish empire: experience in natural disasters and a moving bureaucracy. The Lima Earthquake of 1687, along with other disasters that hit the Spanish empire, may have instilled in state officials a new awareness about calamities and

their effects. Even though officials did not develop a universal, systemic imperial policy to deal with disasters until the end of the seventeenth century, its bureaucrats had learned to design and implement particular responses according to local circumstances.

Among the most challenging local circumstances the Duke faced in the earthquake's aftermath was rebuilding the administrative buildings with the paltry funds in the royal treasury. Indeed, the treasury was in precarious condition as the crumbling architectural structures of the city.

\section{The Reconstruction Projects of the Colonial Administration}

The earthquake heavily damaged various buildings that were visual representations of royal power, such as the viceregal palace and the city hall. The Viceroy was conscious that the royal treasury would have to fund the reconstruction of these former entirely but he expected to find other sources to repair the latter. He knew the precarious condition of 
the royal treasury represented a financial challenge for his rebuilding projects. Nonetheless, he was determined to make them happen.

Urbanism played a crucial element in providing power to the ruling elites. The geography of Spanish American cities embodied the heterogeneous and hierarchical nature of the colonial societies and their governmental system. ${ }^{209}$ The crown delineated the guidelines for the foundation of the city and the distribution of its blocks. The growth of Lima brought about many transformations to its architecture, both secular and religious. A few decades after its foundation, stable and permanent houses replaced the provisional and experimental ones the conquerors had built. Limeños began to build two-story residences since the 1570s. They mainly used lime, bricks and stones to build façades, columns, and foundations, and employed adobe to fill the interior walls. Starting in the 1620s, wood became the most demanded product used in the upper-stories because of its flexibility and resistance to tremors. Quincha (mud-covered framework of wood or reed) and reed were also other original and flexible materials that builders used in their projects. ${ }^{210}$

\footnotetext{
${ }^{209}$ Ernesto Capello, City at the Center of the World. Space, History, and Modernity in Quito (Pittsburg: University of Pittsburg Press, 2011), 6.

${ }^{210}$ Antonio San Cristóbal, La Casa Virreinal Limeña de 1570 a 1687, tomo 1 (Lima: Fondo Editorial del Congreso del Perú, 2003), 97.
} 
The frequency of telluric movements in Lima also affected the construction patterns of religious structures. Religious buildings followed new architectonic plans and vaults as they required repairs or reconstruction. By 1660s, plaster and wood began to replace bricks, stones, and limes in the constructions of vaults and arches because they were more flexible and resistant. It was until after the Earthquake of 1687 that quincha, wood, and plaster became more popular among construction masters because domes made with these materials had resisted the intensity of the natural event. ${ }^{211}$

The original design of the city followed a symbolic order where every element had its specific place, and the plaza functioned as a theater from where the political system displayed authority through both administrative and religious buildings. ${ }^{212}$ The appearance of public buildings had the purpose to manifest the power of the government. ${ }^{213}$ In Lima, as in other cities, royal power was concentrated on the Plaza Mayor, which represented the

\footnotetext{
${ }^{211}$ Antonio San Cristóbal, Arquitectura de Lima en la Segunda Mitad del Siglo XVII (Lima: Fondo Editorial de la Universidad de San Martín, 2010), 225, 226.

212 Alvaro Félix Bolaños, “A Place to Live, a Place to think, and a Place to Die: Sixteenth Century Frontier Cities, Plazas, and 'Relaciones' in Spanish America,” in Mapping Colonial Spanish America. Places and Commonplaces of Identity, Culture, and Experience, edited by Santa Arias and Mariselle Meléndez. (London: Associated University Presses, 2002), 285.

${ }^{213}$ Kinsbruner, The Colonial Spanish-American City, 49, 50.
} 
core of urban social, political, and cultural life. ${ }^{214}$ Because of the symbolic power of buildings, ruling groups elaborated imposing constructions. Both the viceregal palace and the city council had two-stories, two interior patios, and several chambers that functioned as dependencies of diverse governmental branches. Stones and bricks were the main materials utilized in both buildings for the foundation, ground level columns, and façades. Wood was mainly used for second story corridors and balconies. ${ }^{215}$ Unfortunately, the expenses of carrying out the reconstruction of these public buildings were extremely burdensome on the royal treasury. ${ }^{216}$

Despite the various financial responsibilities of the royal treasury, the colonial administration's primary duty was to remit bullion to the peninsula in order to support the king's diverse enterprises. The Duke understood that the King prioritized royal revenue above rebuilding. He recalled in his memoir, "Even though in defense and safety of the life, honor, and wealth of such good vassals His Majesty would employ all his treasures with great joy, I cannot offer them in present times, because the troubles of the Monarchy

${ }^{214}$ Osorio, Inventing Lima, 152.

215 Jorge Bernales Ballesteros, Lima. La Ciudad y Sus Monumentos (Sevilla: Consejo Superior de Investigaciones Científicas, Escuela de Estudios Hispano-Americanos, 1972),126, 193, 194.

${ }^{216}$ Navarra y Rocaful, “Memoria de Gobierno,” 18. 
in the closest parts to the heart [the peninsula], need all the aid and assistance of his royal treasury, without diverting them to another part (Lima).” ${ }^{217} \mathrm{He}$ underlined that such troubles at the court were more important than providing financial relief to Lima's loyal subjects.

Despite the significant role Lima played in the crown's imperial structure as a commercial, fiscal, and administrative center of South Spanish America, peninsular authorities perceived the immediate material needs of the colonial subjects as distant. ${ }^{218}$ The Duke, a peninsular bureaucrat in the New World, was aware that the King and his main ministers understood the metropolis’ economic needs were a priority. Therefore, he had to fulfill the double task of reconstructing Lima and sending funds to the peninsula.

The destruction of all the public buildings in the city represented exorbitant expenses for the royal treasury, which was in a chronic deficit. The Duke realized that the royal treasury would be unable to defray the costs to repair and reconstruct all the buildings. Yet, when he took on this project, he resorted to various mechanisms to reduce costs or

217 Ibid, 367.

${ }^{218}$ Sellers-García, Distance and Documents at the Spanish Empire’s Periphery, 15, explains that even colonial centers remained distant from the perspective of the metropolis. These centers, as the large cityports across Spanish America, had the main function of generating the wealth the metropolis required. 
obtain alternative funds. In order to rebuild the viceregal palace, the Duke summoned an emergency meeting, a “junta extraordinaria de tribunales," where he presented his projects of reconstruction to the high-ranking royal officers of the colonial administration. ${ }^{219}$ When asked by the civil authorities, bricklayer Manuel of Escobar recommended the demolition of the viceregal palace's second level in order to spare some undamaged parts of the first floor and convert it into a new building. ${ }^{220}$ The Viceroy argued that the cost of constructing this one-floor palace would be considerably less than repairing the entire building. ${ }^{221}$ Since the new palace would have only one story, as opposed to the two levels in the previous palace, the Viceroy's project would significantly reduce the useful space in the new palace. The viceregal family, the royal tribunals, and other dependencies would have to share the one-floor structure. Nonetheless, the Duke successfully persuaded the junta members to approve his project. ${ }^{222}$ The works on the new viceregal palace began

\footnotetext{
${ }^{219}$ Patricia Marks, Deconstructing Legitimacy: viceroys, merchants, and the military in late colonial Peru. (University Park: Pennsylvania State University Press, 2007).

${ }^{220}$ Account of the City Council, f. 21v.; Relación del Ejemplar Castigo que envió Dios a la ciudad de Lima con los espantosos temblores de 20 de octubre de 1687. BNM, VE - 1461/1.

${ }^{221}$ Account of the City Council, f 18v-31v. provides the testimony of four bricklayers that estimated the reconstruction of the palace between 80,000 to 100,000 pesos.

${ }^{222}$ Letter from the Duke de la Palata to the King, December 8, 1987. BNM, MS. 9375.
} 
immediately, and the first rooms were ready four months later. Aware that the reconstruction activities had started around the city, and many proprietors or tenants returned to their residences or found alternative places to move to, the Duke decided to take advantage of this event to clear the Plaza Mayor, which was still occupied by temporal dwellings. He ordered those that were still living in the plaza to return to their homes or find another place to relocate to. ${ }^{223}$ As the rebuilding of private property began, there was also an increased demand to rent because rental contracts became beneficial for tenants who were willing to repair damaged buildings. ${ }^{224}$ Once the Duke and his family moved back to their palace, tribunals resumed their activities because the royal administrators were able to meet in the rooms vacated by the viceregal family in the Plaza Mayor.

The city hall was another building of important symbolic power for the colonial administration, and it required major repairs. The Viceroy wanted to find alternative sources for reconstructing this building in order to reduce the cost the royal treasury would

\footnotetext{
${ }^{223}$ Mendiburu, Diccionario Histórico - Biográfico del Perú, vol. 8, 103; Account of the City Council, f. 18 v.

${ }^{224}$ Archivo Arzobispal de Lima (hereafter AAL), Santa Clara, XIX:6. On February 13, 1688, the abbess requested license from the Vicario General to rent some houses that were damaged by the quake because "there were some people that want to purchase (in censo) some of them [the houses]" covering their repairs.
} 
have to cover. Various construction masters appraised the costs of clearing the debris and repairing the city hall and provided quotes that ascended to 40,000 pesos. ${ }^{225}$ Unfortunately, the city council had no funds to pay for the reconstruction of its headquarters.

This institution had long faced serious economic troubles. Before the quake, at the beginning of his administration, the Duke discovered the council's longstanding debt and that it often resorted to taking loans from the Caja de Indios, a treasury established exclusively for native subjects in the viceroyalty. ${ }^{226}$ The debt this administrative body had accrued reached 42,000 pesos. The Duke realized that the cabildo could hardly pay back such debt if its treasury remained in a negative balance. Therefore, he channeled new income sources to the city council, which was able to increase its budget by 8,000 pesos. With the Duke's reforms, the city council managed a surplus, which was sufficient to repay the Caja de Indios.

Unfortunately, the earthquake brought down the Duke's recovery plan for the city council's treasury. In addition to its headquarters, the cabildo suffered material losses

\footnotetext{
${ }^{225}$ Account of the City Council, f. 19, 22, 27 v., 32.

${ }^{226}$ Pérez Mallaína, Retrato de una Ciudad en Crisis, 206, defines the Caja de Censos de Indios as a fund derived from a tribute on Indian labor. The money collected was invested in censos whose revenue would benefit the same Indians.
} 
amounting to 36,000 pesos on its propios (municipal properties). ${ }^{227}$ Facing the unexpected costs of repairing all these properties, the counselors asked the Viceroy to grant them some lands in Callao, Carabayllo and Chuquitanta as propios. ${ }^{228}$

The counselors argued that these common land (ejidos) included pastures that the city had possessed since its foundation, or they had plots never assigned previously to any institution or individual. Therefore, no third party would be affected if the Viceroy acceded to their request. ${ }^{229}$ In order to push forward their request, the members of the cabildo appointed commissioners to assess the amount of income these properties could generate according to the quantity of land, houses, and wood available. ${ }^{230}$

\footnotetext{
${ }^{227}$ Moore, The Cabildo in Peru under the Hapsburgs, 155, explains that the propios were rights and properties that the king or his representative conceded to the city council as a corporation to cover its maintenance and functioning.

${ }^{228}$ Memorial del Cabildo de Lima al Virrey Duque de la Palata, Mayo, 23, 1688. AGI, Lima, 87.

${ }^{229}$ Ibid.

${ }^{230}$ Actas del Cabildo de la Ciudad de Lima, f. 158 - 158v.
} 


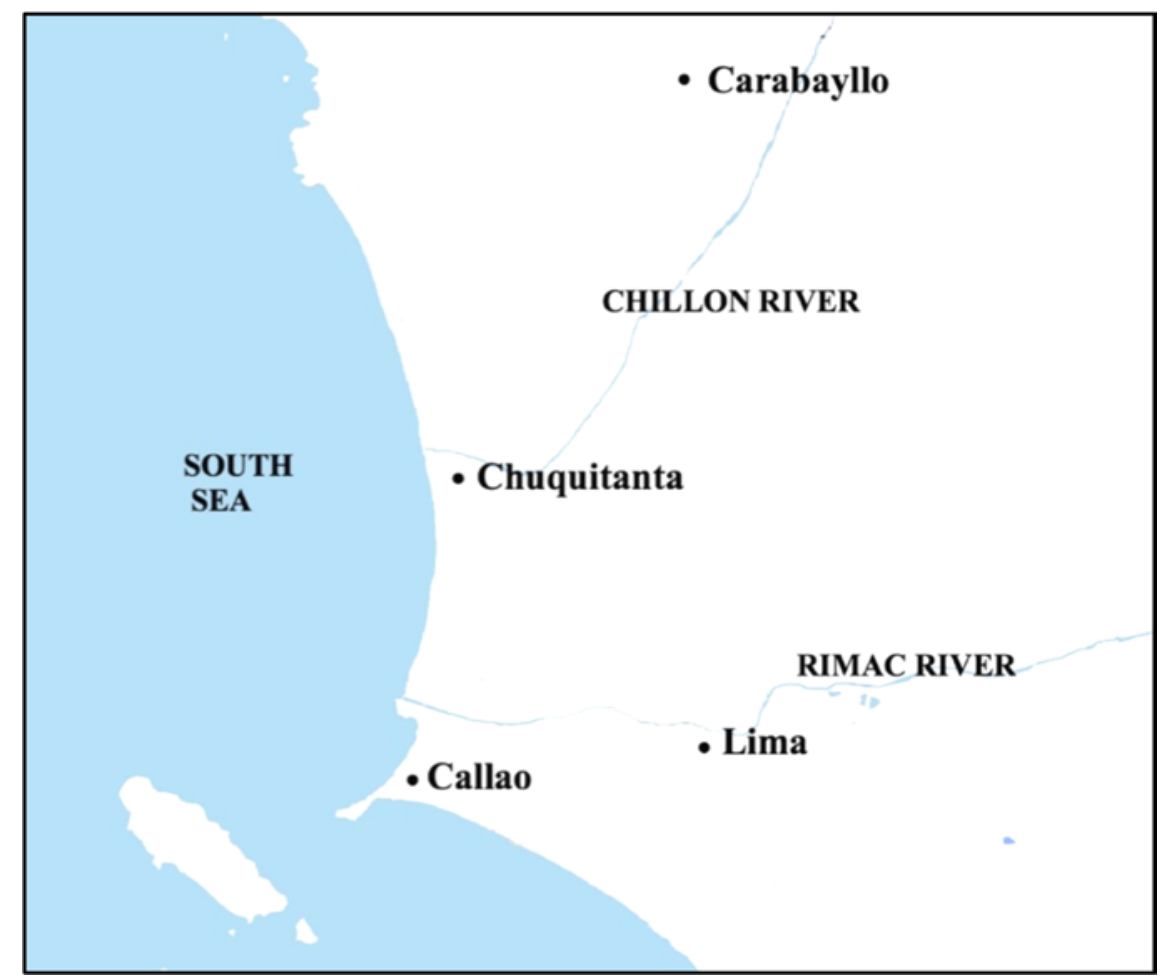

Image 10: Location of lands requested as propios by the city council ${ }^{231}$

The Viceroy saw this initiative of the counselors as beneficial to the royal treasury, the city council, and the population. In a letter to the King, he justified his decision to grant the city council's petition. He explained that the royal treasury would not have to directly cover the repairs of the city council's properties; the city council could rebuild its properties and repay its multiple debts with the rental proceeds. Lima's residents would benefit from the new tenants' livestock or agricultural production. ${ }^{232}$

\footnotetext{
${ }^{231}$ Map made by the author.

${ }^{232}$ Letter from the Viceroy to the King, June 20, 1688. AGI, Lima 87, the Viceroy requested from the King a final confirmation of this grant. There was a pending sentence from 1664 that conferred part of those
} 
The poor condition of the royal treasury motivated the Viceroy to implement such measures. The city council not only assisted with the implementation, but also with the development of projects to provide funding. Local authorities, whose lives and interests were rooted in their own cities, were probably more prone to cooperate with the administrators of the central government when it benefitted the city. ${ }^{233}$ As long as they perceived the administration of the viceroy as fair and "conveniente", they supported his measures and projects.

The members of the city council also responded positively to the Duke's order to promptly rebuild the city jail. In a letter to the council, the Viceroy urged its members to quickly tend to the jail because the order and security of the city depended on securely guarding prisoners. The counselors assigned the proceeds from the penalties imposed on the suppliers of fat and beef to the jail reconstruction. ${ }^{234}$ In other

\footnotetext{
lands as royal property. During the auction of the lands, Don Pedro Garcia Vaquero appealed the process arguing that it involved litigious properties. For that reason, the Duke requested the King to confirm the concession of those lands.

${ }^{233}$ Braddick, State Formation in Early Modern England, 16, argues that the success or failure of office holders depended on their responses to diverse demands.

${ }^{234}$ Actas del Cabildo de Lima, f. 178 - 179.
} 
words, social order was funded by disorder: the city jail was rebuilt with the the fines charged to meat and tallow suppliers for distributing poor quality products, construction workers who demanded excessive salaries, and the sellers of overpriced construction materials. ${ }^{235}$

The rapid negotiations to restore the rent from the alhóndiga, or granary, also display the council's interest in restoring its sources of income. The earthquake had drastically damaged the building of this granary, which belonged to the city. Because of the excessive cost of rebuilding, tenant Don Juan de Soto, knight of the order of Alcántara, requested permission from the council to relinquish the leasing contract (called a censo) he held. He also paid 400 pesos as compensation for prematurely ending the contract. The counselors decided to accept de Soto's request in order to lease the granary to a new tenant who might be willing to cover the reconstruction of the property. ${ }^{236}$

Therefore, the city council was not an administrative body that blindly obeyed the viceroy's orders. Its members actively contributed to both develop and implement measures and plans of reconstruction. As the next chapters will reveal, this distinguished

\footnotetext{
${ }^{235}$ Ibid, f. 170v - 173v.

${ }^{236}$ Ibid., f. 163v-166v.
} 
them from royal officers of the Real Audiencia, the Tribunal de Cuentas, and other administrative branches. City counselors worked from the start of the reconstruction process along the Viceroy.

\section{Conclusion}

The Spanish colonial administration's capacity for crisis management was both effective and pre-modern. The Viceroy, as representative of the king, fulfilled his responsibilities in a commendable manner. Amidst the widespread chaos and destruction of Lima, he was a tenacious figure that brought comfort to the dispossessed population of city. Even though his capacities were not exceptional, he displayed remarkable leadership and organizational faculties. He adopted diverse measures to effectively deal with the growing demands of the city. Along with other royal officers, he pioneered an effective response to the disaster.

Providing for people’s material needs and the reconstruction of the city’s buildings was an enormous undertaking that surpassed the capabilities of any one individual. The Viceroy played a leading role; yet, the large scope of his plans was possible through the active participation of the members of the city council. Rather than retiring to their homes 
to rest from the earthquake's fury, the counselors gathered with the Viceroy to design the various measures to manage the crisis faced by the city.

Altogether, the royal administrators developed different strategies to respond to the crisis in the short and long term. The new conditions of the city, such as the dispersion of people throughout the city, limited the distribution of food, medical assistance, and control of social order. Nonetheless, the administration of the city was able to reorganize its activities in order to increase the supervision of food provision and the number of officials in charge of controlling order in the city.

The poor condition of the royal treasury created severe limitations on potential reconstruction projects. The royal officers chose the least expensive alternatives, such as the reconstruction of the new one-story viceregal palace. The Viceroy and counselors also developed new strategies to increase the number of funding sources, such as fines on food distributors and construction laborers. The city council also negotiated with the Viceroy new usufruct rights over its holdings to increase its budget. The Viceroy agreed because he understood that this institution needed the income and would relieve the burden on the royal treasury. 
It is evident that the Viceroy implemented diverse measures to tend the different needs of Lima's residents after the earthquake. When the Viceroy awarded the city council the land in Callao, Carabayllo and Chuquitanta, he conceded the grant hoping it would provide the necessary means for the cabildo to both cover its expenses and repay its debt to the Caja de Indios. At the same time, the royal treasury would benefit from this measure because the council would not request additional assistance from the overloaded treasury after receiving the new grant. When the counselors imposed penalties on rogue food suppliers, their pursuit targeted a triple goal: punish the offenders, compensating consumers, and provide the economic means to build the city jail.

Overall, the colonial administration of Lima was able to cope with the crisis context that the Earthquake of 1687 produced. Royal officers adapted to the critical circumstances and dealt with the new configurations of dwellings, shortage of food, and predictable scams that some residents attempted to pull off during the chaos. With rapid organization and effective measures, the royal administrators were able to manage the effects of the earthquake. Far from incompetent, the measures of the Duke and the city council demonstrated a creative capacity to tend to people's basic needs and initiate the 
reconstruction of the city. Decisions were carefully crafted to provide what was most "conveniente" or balanced for each sector of the colonial society.

During the months following the quake, the reconstruction of the city involved not only royal agents but also other people in positions of leadership. Nonetheless, not all of them were as enthusiastic about participating in the rebuilding activities as were the Viceroy and city council. Even though the Church was an important component of the colonial enterprise, its complexity became evident in the aftermath of the earthquake. The secular clergy, unlike the religious orders in the city, resisted the reconstruction projects of the colonial administrators. 


\section{CHAPTER 3: A SEEMINGLY STRONG SURFACE: INTERNAL DIVISIONS AND INTRICACIES OF THE COLONIAL CHURCH}

Even when both secular and regular clergymen shared common spiritual objectives

and functions, the constitution of both religious branches in the New World and their relationship to the crown influenced their temporal and spiritual activities. The earthquake unveiled the intricate nature of the Church's constitution, functions, and interests, which were not always oriented to serve the needs of the spiritual herd of Lima.

The composition of the colonial church resulted from a contradictory and parallel process of development of both the secular and the regular clergy in the New World. After the conquest, the Pope granted the Spanish kings a series of cumulative rights in exchange of evangelizing the lands recently discovered. In 1501, he conceded to the Spanish royalty the tithes collected in the Indies. In 1508, the monarchs obtained the right to present the candidates for ecclesiastical posts in the New World to the Pope. In 1543, the Pontiff gave 
the Spanish kings permission to establish ecclesiastical jurisdictions. ${ }^{237}$ Because of these rights, which constituted what was called "Royal Patronage," the Spanish crown built a large ecclesiastical structure of various new jurisdictions within the newly conquered lands. In contrast to the royal rights that shaped the secular clergy in Spanish America, the papal bull Omnímoda of 1522 granted broader privileges to the religious orders. It specifically conceded to them the ability to administer sacraments and gave them jurisdiction over canon law, which secular clergy traditionally exercised, in areas with no diocesan presence. ${ }^{238}$ In the following decades, regular clerics began to arrive in the New World in great numbers, and took a leading position in the evangelization of indigenous people, and the foundation of churches and convents. Even though the bull granted such rights only in case of absence of the secular clergy, friars resisted giving up these prerogatives, claiming they possessed superior capacity and morality to tend to the

\footnotetext{
${ }^{237}$ Lyle McAlister, Spain and Portugal in the New World: 1492 - 1700 (Oxford: Oxford University Press, 1984), 194, 195; Eric Deeds, “Church History, Institutions and Archives,” Guide to Documentary Sources for Andean Studies, 1530 - 1900, edited by Joanne Pillsbury, vol. 1(Norman: University of Oklahoma Press, 2008), 164; Moore, The Cabildo in Peru under the Hapsburgs, 209.

${ }^{238}$ Mark Burkholder, Spaniards in the Colonial Empire: Creoles vs. Peninsulars? (Malden, MA: WileyBlackwell, 2013), 29.
} 
Indians’ spiritual needs. ${ }^{239}$ The clashes between the secular and the regular clergies would vex the crown's attempts to impose strong control on the church's activities.

The regular clergy developed a strong presence in the viceroyalty's interior provinces, where Indians represented a large percentage of the population. Nonetheless, as capital of the viceroyalty, Lima concentrated an extensive religious population, both female and male, who occupied the low and high-ranking positions in the various clerical hierarchies. The Cathedral, the archbishopric palace, and other principal convents and monasteries of the religious orders made Lima a concretely religious city.

There were sixty-five religious buildings in the city by the time the quake hit Lima, as mentioned in chapter 2. Located in front of the Plaza Mayor, a few steps from the viceregal palace, the Cathedral and the adjacent archbishopric palace reflected the close ties between the crown's government and the secular church. There were also the parishes of San Sebastian, Santa Ana, San Marcelo, and De los Huerfanos (The Orphans). ${ }^{240}$ The largest religious orders of San Agustín, Santo Domingo, San Francisco, La Merced, and Compañía de Jesús had built twenty convents. These regular clerics also took care of two

\footnotetext{
${ }^{239}$ Lyle McAlister, Spain and Portugal in the New World, 195, 196; Burkholder, Spaniards in the Colonial Empire, 30.

${ }^{240}$ Doering \& Lohmann, Lima, 95, states that San Lazaro parish existed since 1626, yet it was out of the limits of the city, in the San Lazaro neighborhood.
} 
hospices, eleven hospitals, an orphanage, and a lay seclusion house. They also administered the chapels of the university, the Inquisition, three schools, and other chapels in the city. There were sixteen institutions for females: eleven of them were monasteries of nuns, such as Santa Clara and Concepción, and 5 beatarios (lay spiritual houses). ${ }^{241}$

As representative of the Spanish Crown's right of Royal Patronage, the Viceroy attempted to extend some of his pre-earthquake reforms to the Church. Upon his arrival in Lima, one of his first priorities was to limit the excesses that some priests committed, specifically against the Indians. The Viceroy issued a viceregal decree on February 20, 1684, that entrusted royal officers to inform ecclesiastical superiors of any misdeeds by priests and friars. His measures to bring the religious under control produced a strong and widespread reaction from members in all levels of the ecclesiastical hierarchy, who understood the decree as a threat to their ecclesiastical immunity. ${ }^{242}$ The numerous convents and the religious presence in Lima gave an outward appearance of unity and strength. Despite the unified image both the secular and regular clergies portrayed

\footnotetext{
${ }^{241}$ Account of the City Council, by Diego Fernández Montaño, f. 1v.

${ }^{242}$ Margaret Ellen Crahan, “Clerical Immunity in the Viceroyalty of Peru,” $102-103$.
} 
defending its ecclesiastical privileges, their performances during the earthquake's aftermath contrasted.

Both private and official accounts report that the religious building structures suffered great destruction with the quakes of October 20, 1687. ${ }^{243}$ These records help us reconstruct the response, in the short- and long-term, by the city's religious hierarchies. Even though most of them are official records, they were produced by different institutions, both civil and religious, and offer diverse perspectives and interpretations about similar events or practices. Contrasting these varied documents, it is possible to obtain a reliable account of the performance of both branches of the Spanish church.

After the quake hit Lima, both secular and regular clergy suffered destruction of their properties. Some of their members died, while the survivors endured precarious living conditions. On one hand, religious orders rapidly engaged in diverse activities of spiritual relief, and organized to rebuild their estates and reactivate the revenue of their rents. On the other hand, the secular clergy hesitated to fulfill their spiritual activities until building a temporal chapel appropriate for their functions, and refused to economically support the

\footnotetext{
${ }^{243}$ Account of the City Council, f. 9 v; Relación del Ejemplar Castigo que envió Dios a la ciudad de Lima con los espantosos temblores de 20 de octubre de 1687. BNM, VE - 1461/1.
} 
reconstruction of religious property arguing this task corresponded to the king, as patron

of the Church in the New World.

The contrasting performance of both clergies influenced the perception of the royal authorities, who received collaboration from the religious orders in organizing repentance activities, while secular ministers became stubborn opponents to the government's reconstruction projects. Secular prelates' refusal to economically support the rebuilding of the Cathedral required negotiation, legal arguments, and the final intervention of the Pope. Even when the viceroy was unable to bargain with the members of the ecclesiastical council, he had the legal mechanisms to compel them to obey the orders of the royal government.

\section{Spiritual Relief: Where Was the Archbishop?}

After the first tremor hit the capital that terrible night, those who were able to escape from their homes fled to the various churches throughout the city, seeking refuge and spiritual relief. Since early modern people considered natural disasters, and especially earthquakes, as manifestation of God's wrath, the ordinary reaction when catastrophic experiences occurred was to look desperately for spiritual comfort. ${ }^{244}$ They believed that

\footnotetext{
${ }^{244}$ Palacios Roa, Alfredo. "La Sensibilidad religiosa frente a las catástrofes naturales (1563 - 1730)” in Historia de la Iglesia en Chile: En los caminos de la conquista espiritual, vol. 1 edited by Rodrigo Moreno
} 
natural disasters were warnings or punishment of an angry God for multiple sins. Limeños

thus expected the clerics to provide spiritual assistance to the bereaved souls, receiving and

absolving their sins. Further, they attributed catastrophe to divine power and believed they

could do little themselves to alter the course of events except in the spiritual realm. ${ }^{245}$ They

offered public demonstration of repentance for their sins and attended processions, public

sermons, and masses that were accompanied with laments, cries, and self-inflicted

punishments. ${ }^{246}$ In Lima, some of these exercises of repentance became so extreme that the

Jeria, directed by Marcial Sánchez Gaete, coordinated by Marco León León (Santiago: Editorial Universitaria, 2009), 345-367.

${ }^{245}$ According to Jussi Hanska, Strategies of Sanity and Survival. Religious Responses to Natural Disasters in the Middle Ages, Studia Fennica Historica 2 (Helsinki: Finnish Literature Society, 2002), 128, in pre modern times, natural disasters were explained not only by God's wrath, but also scientifically. Nonetheless, even the latter included elements of God's intervention.

246 This conception about natural hazards was evident in several interpretations made by the contemporaries in which natural disasters were only merciful warnings of God who was going to send his final punishment to his disobedient children. Visions and premonitions of God's ultimate sentence were made public during the reconstruction period. They were mainly use to regulate the moral of the population; yet they also served to question the conduct and legitimacy of the authorities. Charles Walker, "Great Balls of Fire. Premonitions and the Destruction of Lima, 1746," Aftershocks: Earthquakes and Popular Politics in Latin America, edited by Jürgen Buchenau and Lyman L. Johnson (Albuquerque: University of New México Press, 2009): 18 - 42; Valenzuela, Jaime. "El Terremoto de 1647: Experiencia apocalíptica y representaciones religiosas en Santiago Colonial”. Historias Urbanas. Homenaje a Armando de Ramón, edited by Jaime Valenzuela (Santiago: Ediciones Universidad Católica de Chile, 2007): 27 - 65. 
authorities prohibited the excessive performances in order to avoid the death of the penitents. $^{247}$

Regular clerics took a leading role in these spiritual activities, bringing both comfort and admonition to Lima's residents. As soon as the first great quake ended, clerics such as Fray Joseph Buendía and Fray Pedro Medina left convents and other religious institutions where they lived in order to assist the hapless souls who were dying or looking for confession to relieve their conscience. ${ }^{248}$ Some religious ministers began to preach in the streets, and others went to minister in the churches. ${ }^{249}$

Those who sought protection at the temples had made a mistake. Two hours later, with the second tremor, almost all the churches that remained standing collapsed, burying alive the religious and lay people that were inside. A contemporary witness recalled that the soil "shook and shook in a way that it was the vivid representation of the Final Judgment.”250 A tower of Santo Domingo’s church and the upper part of the choir area

\footnotetext{
${ }^{247}$ Account of the City Council, by Diego Fernández Montaño, f. 5v.

${ }^{248}$ Buendía, Relación del temblor que arruinó a Lima el 20 de octubre de 1687, 24; Alexandre Coello de la Rosa, "La Destrucción de Ninive: Temblores, Políticas de Santidad y la Compañía de Jesús (1687 - 1692),” Boletín Americanista, LVIII, 58 (2008), 154.

${ }^{249}$ Luis Sifuentes de la Cruz, “Lima y los desastres sísmicos de 1687 y 1746”, Demiurgo, 2 (2004), 111.

${ }^{250}$ Relación del Temblor que sucedió en Lima lunes 20 de octubre de 1687, BNM, MS. 18760/36, f. 53 v.
} 
collapsed on the main aisle, killing those that had conglomerated inside looking for confession. ${ }^{251}$ San Francisco church’s dome and cross suffered great ruin, Nuestra Señora de las Mercedes temple's structure fell to the ground, and San Agustin church's main chapel and cruise collapsed. ${ }^{252}$ The extensive devastation of religious buildings accentuated the people's concern because it reinforced their belief that the tremors were truly the result of God's wrath. ${ }^{253}$ During the hours and days following the earthquake, Lima's people paid close attention to the sermons and engaged in processions, contrition displays, and other demonstrations of devotion as people cried out for divine mercy. ${ }^{254}$

${ }^{251}$ Buendía, “Relación del temblor que arruino a Lima el 20 de octubre de 1687,” 27.

252 Ibid, 28, the church of San Juan de Dios' cruise and tower also collapsed, and many nave vaults of the cathedral suffered equal damage.

${ }^{253}$ Ivan del Valle y Caviedes, Romance en que se Procura pintar, y no se consigue; la Violencia de dos terremotos, con que el Poder de Dios asolo esta Ciudad de Lima, Emporeo de las Indias Occidentales, y la mas rica del Mundo. BNM, VE 1478 - 4, provides a description of the churches, and convents that collapsed over people and served them as tombs.

254 Alfredo Palacios Roa. “La Sensibilidad religiosa frente a las catástrofes naturales (1563 - 1730),” 347 67; Charles Walker, “Great Balls of Fire. Premonitions and the Destruction of Lima, 1746,” Aftershocks, 18 - 42; and Jaime Valenzuela, “El Terremoto de 1647: Experiencia apocalíptica y representaciones religiosas en Santiago Colonial”. Historias Urbanas, states that in pre -modern societies people understood natural hazards as merciful warnings of God to his disobedient children. 
The religious orders of La Merced, San Agustín, and Santo Domingo rapidly built provisional chapels on the Plaza Mayor from their own funds in order to continue officiating their daily religious services, confessing and absolving the many persons that arrived in quest of spiritual relief. ${ }^{255}$ At the same time, they diligently worked to repair their main churches, which were completely destroyed in the quake.

The members of the ecclesiastical council also erected a provisional chapel in the Plaza Mayor, yet not as fast as the regular religious. More than one month after the quake, the prelates were still discussing the details about the new temporary chapel. They voted to assign 1000 pesos to build a place "to put the silver shrine with all the decoration of the best jewels of the church," so they could "comply in it with the obligation of the divine offices, and assist to these the gentlemen of the council so it would appear a more decent place.”256 The meeting records of this institution reflect that the construction of the provisional chapel was more a temporal than an spiritual concern for the prelates. They planned a chapel that would represent their social prestige, and permit them "to comply

${ }^{255}$ Account of the City Council, f. 11; Relación del Ejemplar Castigo.

${ }^{256}$ Actas del Cabildo Eclesiástico de Lima, Archivo Catedralicio de Lima (hereafter ACL), November 22, 1687, f. 206v-207, “se ponga el [altar] de plata con todo el adorno nuestro de las mejores al[h]ajas de la iglesia (...) [y] se pueda cumplir en ella [la capilla] con la obligación de los oficios divinos y asistir a ellos los señores del cabildo por parecer lugar mas desente...” 
with its [...] obligations." ${ }^{257}$ These sources also remain silent about prelates’ concern about providing spiritual relief to the population. The members of the ecclesiastical council appear to have been mainly focused on building a chapel that would visually represent their social standing.

Despite the prelates' efforts to build a decent place, they had to conform with a less sumptuous chapel because the cost of the structure they envisioned reached 6000 pesos. Because of the limited budget they assigned for the provisional chapel, the prelates had to resume their obligations in a hut without walls, closing three sides with damask and velvet hangings to give some decency to the place. ${ }^{258}$

While the members of the city council concentrated efforts on improving the appearance of their chapel, and the friars from different religious orders focused on both spiritual and temporal activities, the Archbishop was absent. When the earthquake hit, Archbishop Don Melchor de Liñán y Cisneros was in Callao. On the recommendation of

\footnotetext{
${ }^{257}$ Ibid, 208, in the meeting of the ecclesiastical council regarding the construction of the provisional chapel, there are no references to the spiritual assistance to Lima's people. The prelates, many of whose names were recorded by the notary, describe the necessity of the chapel to comply with obligation and show the decency, through the exposition of jewels, of the council.

${ }^{258}$ Ibid, 209v.
} 
his physician, he had moved to the port to recover from choking attacks. ${ }^{259}$ He was sleeping when the first quake hit, and the roof of the bedroom collapsed on top of him. Fortunately, his steward Francisco de Jauregui and other servants were able to rescue him from the wreckage. The worst came a few hours later when a tsunami hit the port and flooded the entire town. The Archbishop narrowly escaped from the water's power. A witness described his clothes as damp when four slaves carried him on their shoulders to take him from the port. After his return to Lima, he retreated to a rural estate in Late, located two leagues from Lima. ${ }^{260}$ His absence became evident during the days of major spiritual commotion.

\footnotetext{
${ }^{259}$ Memorial of the merits of Dr. Don Melchor de Liñán y Cisneros, Archbishop of the Iglesia Metropolitana of Lima, n. d. AGI, Lima, 520, f. 2.

${ }^{260}$ Relación del Ejemplar Castigo.
} 


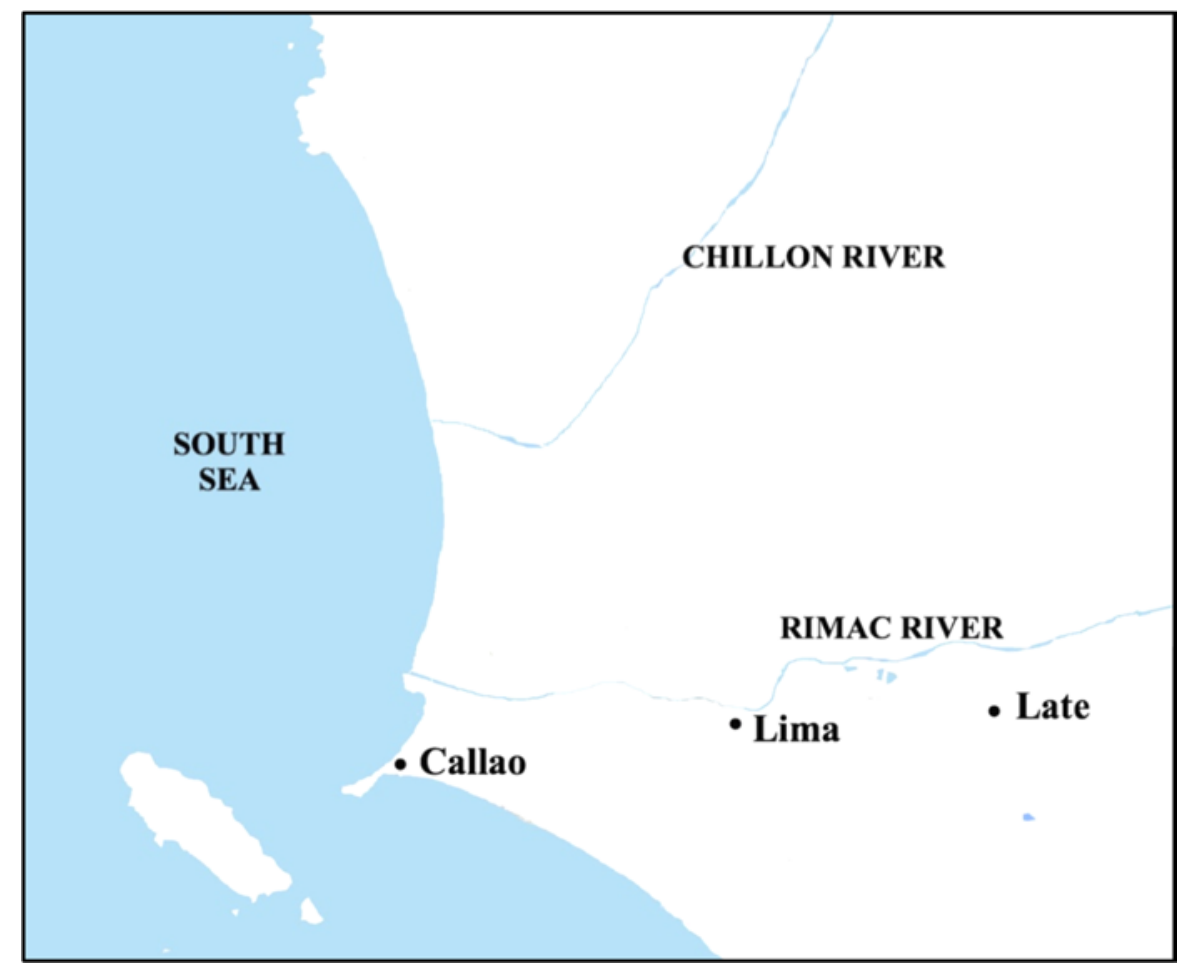

Image 11: Location of Late. ${ }^{261}$

Because of the Archbishop's absence, the Viceroy himself became a central figure even in activities of religious character. Among his first instructions in religious matters, he ordered that the most venerable images in the city, the Virgins of Rosario, Merced, and Guía, be brought to the temporal chapels built in the Plaza Mayor by the religious orders. Three days after the quake, the Duke and his entire family even accompanied the Virgin of the Rosario as the image was carried at the Plaza Mayor from the church of Santo Domingo

${ }^{261}$ Map made by the author. 
in a procession. ${ }^{262}$ The Viceroy took special interest in bringing the Virgin of Tears (de la Lágrimas) and renaming it as the Virgen of Warning (Anuncio) because this image had miraculously started to cry a few months before the quake. The Duke designated October 20 as the day of this image's feast as a gesture of thanksgiving for forewarning the city from the punishment of Jesus Christ. ${ }^{263}$

After the quake, limeños participated in diverse demonstrations of contrition along with the Duke, who even appeared with a rope around his neck as symbol of contrition in one of many processions he attended. ${ }^{264}$ Regular clergy collaborated in the penitent activities in the city, delivering sermons with messages of exhortation. The best preachers of the religious orders went to the streets to persuade Lima's inhabitants to repent. ${ }^{265}$ The secular clergy, on the other hand, only tended to some chapels built by individuals around the city, without taking leading roles in the spiritual activities of the population.

\footnotetext{
${ }^{262}$ Relación del Temblor que sucedió en Lima lunes 20 de octubre de 1687. BNM, MS. 18760/36; Relación del Ejemplar Castigo que envió Dios.

${ }^{263}$ Mendiburu, Diccionario Histórico - Biográfico del Perú, vol. 8, 109; Melchor de Navarra y Rocafull, “Memoria de Gobierno,” 115.

${ }^{264}$ Relación del Ejemplar Castigo que envió Dios.

${ }^{265}$ Alexandre Coello de la Rosa, “La Destrucción de Ninive: Temblores, Políticas de Santidad y la Compañía de Jesús (1687 - 1692),” 153.
} 
Different from Liñán y Cisneros, the Viceroy was present in processions and other religious activities that aimed to placate divine wrath. His performance contrasted with the nonappearance of the Archbishop in the following weeks after the quake. Contemporaries noticed that "he [the archbishop] was unable to return to this city, although he came injured and wounded to entrust his obligations to the general vicar." ${ }^{266}$ The Viceroy emphasized, although with certain sarcasm, that it was not the Archbishop’s fault that “God intended to take away his health and energies" in a moment when his presence was indispensable among his spiritual flock. ${ }^{267}$ Certainly, Liñán y Cisneros had no control of the events that limited his active participation in the penitent activities that the whole population engaged in. Yet, his frail health did not preclude his defiance, along with the members of the ecclesiastical council, of the royal government's rebuilding projects.

\section{Temporal Obligations: Rebuilding the House of God}

According to contemporary witnesses, the earthquake inflicted the most damage on ecclesiastical properties. Almost all religious buildings, except the chapel of the Sagrario,

${ }^{266}$ Relación del Ejemplar Castigo.

${ }^{267}$ Letter from the Duke of the Palata to the King, December 8, 1987. BNM, MS.9375. 
located next to the Cathedral, had collapsed, killing many nuns and friars. ${ }^{268}$ The provincial head of Santo Domingo declared that, under his instructions, the clerics of his order recovered forty-two bodies from under the debris of their convent, which he considered just a fraction of the dead. ${ }^{269}$ The support to the religious population's need and the reconstruction of their cloistered buildings required the attention of the highest colonial authorities, especially those of the ecclesiastical hierarchy. The evidence shows that the regular and diocesan clergy confronted the destruction of the earthquake differently. The distinct relationship between the religious orders and the secular clergy produced different perspectives regarding management of resources and spiritual functions.

Most of the churches, convents, and monasteries of the city had interrupted the regular religious services in their chapels. Instead, friars and priests attended the provisional chapels people had erected in the various settlements they constructed after the

\footnotetext{
${ }^{268}$ Relación del Ejemplar Castigo que envió Dios a la ciudad de Lima, refers San Francisco Church’s dome and cruise suffered great ruin; Nuestra Señora de las Mercedes Church's building fell to the ground; San Agustin Church's cruise and main chapel collapsed; and San Juan de Dios Church also suffered on its cruise and tower. Many nave vaults of the Cathedral suffered equal disaster.

${ }^{269}$ Account of the City Council, f. 11.
} 
quake. Only at the Colegio de San Pablo, where Fray Buendía and Fray Medina were at the time of the first tremor, did Jesuits continue celebrating masses in the chapel. ${ }^{270}$

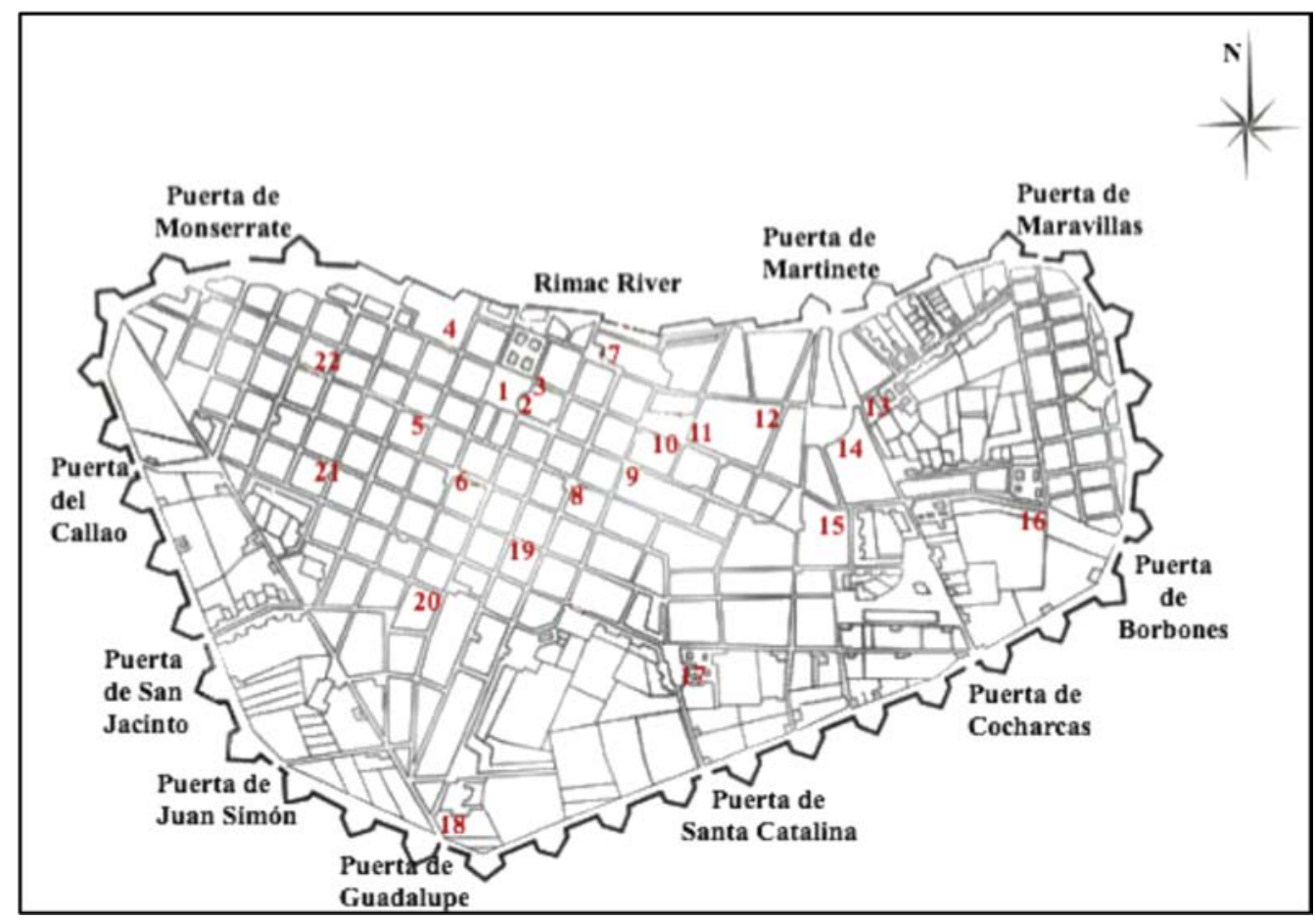

Image 12: Map of principal religious buildings in Lima. 1. Plaza Mayor, 2. Cathedral, 3. Archbishop’s Palace, 4. Santo Domingo, 5. San Agustín, 6. La Merced, 7. San Francisco, 8. San Pablo School, 9. Concepción Monastery, 10. Inquisition, 11. University, 12. Trinitarian Convent, 13. Mercedes Church, 14. Santa Clara Convent, 15. Santa Ana Church, 16. Prado Monastery, 17. Santa Catalina Convent, 18. Guadalupe Church, 19. Huérfanos Church, 20. San Juan de Dios, 21. San Marcelo Church, and 22. San Sebastian Church. ${ }^{271}$

${ }^{270}$ Ibid, f. 5v.

${ }^{271}$ Map made by the author using Rolando Arciga. Plano de Lima donde se ve la ubicación de las puertas que tenía la muralla. 
Because of the destruction of their monasteries and convents, friars and nuns abandoned their seclusion to take refuge in open spaces. They had to compete with other residents for available spaces in the city and surrounding areas. Members of the female orders were among those who displayed the worst dispossession, and their presence underlined the social disorder and chaos in the city. The destruction of the Convent of La Purísima Concepción left dispossessed 310 nuns of "black veil," many other nuns of “white veil,” servants, and lay women; the total surpassed $1500 .{ }^{272}$ The lack of a place to support this human contingent required that 162 black-veiled nuns from La Concepción be moved to the spacious garden of the Convent of Santa Catalina. These elite nuns escaped from their convent when it collapsed with the quake. Once at Santa Catalina's yard, they found the same scenario of destruction. When inspecting the city, the notary of the city council, Diego Fernandez de Montaño, noticed a big hole in the wall of the convent that prevented the seclusion of these women, who became exposed to the threats of nature and the perils of secular life.

The conditions of living outdoors took a toll on the dispossessed religious population. The arrival of the 162 nuns of velo negro from La Concepción Monastery, who

\footnotetext{
${ }^{272}$ Buendía, “Relación del temblor que arruino a Lima el 20 de octubre de 1687,” 29.
} 
probably were accompanied by servants, to the yards of Santa Catalina monastery had also increased the pressures on resources available at the latter location. There were 300 women, among them nuns of white veil, secular women, donadas, and servants from Santa Catalina's monastery living in the yards. The large number of newcomers accentuated the lack of food resources. According to the abbess, the nuns were dying of hunger. The abbess of the Monastery of Nuestra Señora del Prado described a similar scenery because the nuns of her monastery were exposed to inclement weather, without more protection than the one provided by the huts they built among the trees. The worst plight was that of the sisters of Santísima Trinidad, who abandoned their completely devastated monastery and moved to some corralones next to the church of Guadalupe. During the five months they remained there, so many of them died as a result of inclement weather that the Inquisitors, patrons of their monastery, opted to transfer them to some wood huts in a more adequate place. ${ }^{273}$ The hardships of these religious women were not exclusive. Surely most of the population faced them. Yet, the presence of these women, customarily hidden by the high walls of convents, evidenced the social disorder that reigned in the city after the earthquake. These casualties probably concerned authorities that had long tried to limit the number of

\footnotetext{
${ }^{273}$ Ibid, f. 3v-8. Lay sisters of Santa Rosa de Viterbo and Santa Rosa de María had to settle in a barnyard and a dump, respectively.
} 
women in religious institutions. Yet, women increasingly preferred the life of seclusion because it offered refuge, virtue protections, and social promotion to some of them. ${ }^{274}$ Similar to their female counterparts, male religious orders abandoned their convents and became exposed to material adversity. The earthquake, thus, unveiled the increasing economic difficulties of a portion of the city's population who mainly lived from rents and other pious activities rather than other productive occupations. ${ }^{275}$

Although most of the ecclesiastical population was living in dire circumstances, there were also rapid improvements. The provincial of Santo Domingo, Fray Ignacio del Campo, led in person the reconstruction activities in the convent of this religious order. He ordered the destruction of all two-story structures and the church's tower to avoid further collapses. He also rapidly initiated the repair and reinforcement of cloisters and other offices in the first story or ground level. In a few weeks, he was able to relocate most of the friars in these cells, which reduced the pressure on available resources and space. He also sent some clerics to convents and doctrines (missionary outposts) in the provinces to

\footnotetext{
${ }^{274}$ Nancy Van Deusen, Entre los sagrado y lo mundano. La práctica institucional y cultural del recogimiento en la Lima virreinal (Lima: Instituto Francés de Estudios Andinos, 2007), 219.

275 Pérez Mallaína, Retrato de una Ciudad en Crisis, 313 -314; and Walker, Shaky Colonialism, 108, for impact of nuns and friars' presence among secular population after the quake of 1746.
} 
decrease the number of clerics in the convent of Lima. ${ }^{276}$ Because of theses advancements, the city authorities praised how fast the Dominicans were repairing their convent and church.

The possession of extensive rural and urban estates, including monasteries or missions throughout the viceroyalty, offered religious orders alternatives, such as other sources of income or places to relocate members, to initiate recovery activities. ${ }^{277}$ For instance, Monastery of La Encarnación spent 20,707 pesos repairing the building structure of the convent and many other of the order's properties around the city, including houses and stores. ${ }^{278}$ Even though this amount represented one quarter of the total income the monastery received in two years, the administrator's account demonstrated that there was a surplus of 3,600 pesos in those years. ${ }^{279}$ Because the

${ }^{276}$ Ibid, 18v, 23.

277 John Elliot, Empires of the Atlantic World. Britain and Spain in America, 1492-1830 (New Haven: Yale University Press, 2006), 203.

${ }^{278}$ AAL, Encarnación, 16, f. 11-13.

${ }^{279}$ Ibíd, f. 26. The total income of the monastery between September 1687 and August 1689 was of 88,655 pesos 3 reales. The expenses were 85,007 pesos. There was a positive balance of 3,648 pesos 3 reales. 
monastery had these resources available, it was able to rebuild and repair most of its urban real-estate in a couple of years.

The proactive response of various religious orders and institutions during the following days, weeks, and months after the quake contrasted with the activity of the secular clergy. Royal administrators noticed that secular clergy were recalcitrant and reluctant to initiate repairs. Rather than supporting the reconstruction activities and spiritual services in the city, the secular clergy hardly cooperated with the colonial government at all.

\section{Negotiating with Stubborn Prelates}

Like most of the religious buildings in the city, the Cathedral of Lima was extensively destroyed. The Viceroy’s apparent success of initiating the reconstruction of public buildings was challenged by the highest members of the secular clergy when he tried to organize the rebuilding of the Cathedral. The diverse means he proposed to raise funds for the rebuilding activities met the strong opposition of the ecclesiastical council. The long debates that placed the Viceroy in opposition with the Archbishop and the ecclesiastical council illustrates the mechanisms royal authorities employed in order to reach a 
compromise with the highest members of the secular clergy, and how both parties interpreted law and practices to support their demands.

The Cathedral was so seriously damaged that construction masters had calculated reconstruction costs at 60,000 pesos. ${ }^{280}$ The Viceroy recognized that the civil population of Lima, overburdened with the expenses of reconstructing their own properties, was unable to provide financial aid. He also knew that the royal treasury was in a terrible condition and could not afford the rebuilding of all the constructions that needed repairs. Estimates for rebuilding the more than fifty Indian village churches affected by the quake reached 200,000 pesos. Conscious of the importance and conspicuousness of rebuilding the cathedral, the Duke expected to receive financial support from the ecclesiastical council's members, who would be the main beneficiaries.

The Viceroy was confident that the ecclesiastical council's members would accept his proposal to share the expenses of the Cathedral's reconstruction as well as the method he proposed. Since the total project was estimated at 60,000 pesos, he offered to contribute with 20,000 pesos from the royal treasury to initiate the project. He expected the prelates to contribute the remaining amount of 40,000 pesos from the building and maintenance

\footnotetext{
${ }^{280}$ Ibid, 16.
} 
fund (fábrica) of the cathedral, and from individual donations from each of them. Nonetheless, he was greatly shocked by the reluctance of the Archbishop and the prelates to contribute.

The colonial administration commissioned the magistrate (oidor) Don Juan Gonzales de Santiago to act as fiscal in order to inquire about the conditions of the cathedral’s fábrica. Gonzales requested that the steward of the fábrica funds, Don Gabriel of Sumiano, declare the rents and amounts available from this enterprise. Sumiano explained that this fund was divided into interior and exterior accounts. The exterior fábrica account comprised the funds to finance expenses related to the cathedral's structure, such as carpentry, masonry, and similar services. ${ }^{281}$ The interior fábrica was used for the ornaments, music, salaries of some ministers, and some goods used for celebrations and masses, such as candles, wax, wine, bread, and oil.

Sumiano also indicated that, during the four years he had exercised the stewardship of the interior fábrica, this fund provided 10,000 pesos yearly, even though many rents

\footnotetext{
281 Testimony of Gabriel of Sumiano, steward of the metropolitan church, January 13, 1688. Autos que tratan de las diligencias hechas con el Venerable Dean y Cavildo desta Santa Iglesia de Lima para que entre en parte en la reedificación, Lima, May 31 1688. AGI, Lima 87. The Indian tributaries used to pay one tomin to fund these costs up to a few years before the quake, when a judicial order decreed its termination.
} 
were quite behind in payments. ${ }^{282}$ He calculated that debts to the church amounted to approximately 100,000 pesos, from which 60,000 were impossible to collect. ${ }^{283}$ He tried to emphasize the poor condition of the interior fábrica, indicating that he even had to reimburse the previous steward, Capitan Miguel de Medrano, 12,301 pesos that he had provided to cover expenses for masses during the time of his stewardship. Sumiano finally stated that it was not the obligation of the interior but of the exterior fábrica to finance the reconstruction of the cathedral.

Rather than convincing fiscal Gonzales de Santiago of the poor state of the finances of the building fund, Sumiano's declaration only ignited more questioning from the fiscal, who saw the division of the fábrica between interior and exterior funds to be an evasive pretext. Fiscal Gonzales demanded that the judge of the Real Acuerdo, an assembly appointed to serve as advisers of the viceroy, compel Sumiano to show the fábrica books

\footnotetext{
${ }^{282}$ Ibid. He specified that the noveno y medio, the casa excusada, and small censos provided, in theory, the funds to the interior fábrica, but most of them were behind on payments. Recopilación de las Leyes de los Reynos de Indias edited by Ignacio Boix (Madrid: 1841), 100, defines the novena y medio as one and a half ninths of a half of the tithes; and the casa escusada as the richest house in the parish, whose tithes went to the fabrica of the cathedral.

${ }^{283}$ Testimony of Gabriel of Sumiano, January 13, 1688. Autos que tratan de las diligencias hechas con el Venerable Dean y Cavildo. He indicated despite various diligences there were big debtors, such as the Maestre de Campo Don Fernando de Castro, who owed around 20,000 pesos.
} 
from his present administration and that of his predecessor Medrano. ${ }^{284}$ He was interested in knowing how the ecclesiastical council had disbursed 10,000 pesos each year, when other parochial churches, such as those of Callao, Santa Ana, San Marcelo, San Sebastian, and El Sagrario, had annually spent only 200 pesos each. ${ }^{285} \mathrm{He}$ did not know that the interior fábrica was paying the salaries of sacristans and other posts that theoretically should have paid through other sources. ${ }^{286}$

The steward Sumiano resisted showing the books, alleging that the church's accountant had his predecessor's records, and his own book had information about church's matters that could not be exposed. In the face of this refusal, the fiscal tried to review the documents that were in possession of the accountant Juan Esteban de la Parra. The fiscal's

${ }^{284}$ Herbert Ingram Priestley, José of Gálvez. Visitador General of New Spain (Berkeley: University of California Press, 1916), 59, 61, the Real Acuerdo was the meeting of the members of the Real Audiencia as body of consult to the viceroy gathered in special and grave circumstances. The Real Audiencia did not meet and function as a court in various months after the quake, yet continued providing advice to the king, and judging on very sensitive matters.

${ }^{285}$ Petition of the Fiscal, March 21 1688. Autos que tratan de las diligencias hechas con el Venerable Dean y Cavildo.

${ }^{286}$ Letter from the Duke of the Palata to his Majesty, December 8, 1687. AGI, Lima, 87, explain such salaries should have been paid from the gruesa, the total of the tithes, and not from the fábrica fund. 
attempts were unsuccessful because Parra continually declined to show the account records citing as pretext the infirmities of his age $\mathrm{e}^{287}$

Doctors of canon law Don Melchor de la Nava and Don Gregorio de Loayza, as representatives of the ecclesiastical council, along with the Archbishop (despite the enormous pain he was experiencing after almost dying during the quake) gathered with the members of the ecclesiastical chapter to discuss the reconstruction of the cathedral. ${ }^{288}$ They agreed that the only source they had on hand to rebuild the cathedral was the mercy of the king, as patron of the church, because the quake had greatly reduced their incomes from tithes in various parts of the episcopal jurisdiction. ${ }^{289}$ They defended their position arguing that, because of the Spanish king's prerogative of royal patronage, the monarch was required to cover the entire cost of rebuilding the Cathedral. ${ }^{290}$ They enumerated previous

\footnotetext{
${ }^{287}$ Memorial of Gabriel de Sumiano, January 29, 1688; and Petition of the Fiscal, March 21 1688. Autos que tratan de las diligencias hechas con el Venerable Dean y Cavildo.

${ }^{288}$ Actas del Cabildo Eclesiástico, ACL, f. 216v. On April 1, 1688, the members of the council named De la Nava and Loayza as Deputies to attend the negotiations regarding the cathedral's reconstruction with the viceroy.

${ }^{289}$ Memorial of the Venerable Dean and Council. Autos que tratan de las diligencias hechas con el Venerable Dean y Cavildo.

${ }^{290}$ Actas del Cabildo Eclesiástico, ACL, f. 210
} 
occasions in which the royal administration had contributed to reconstruction activities in conformity with royal patronage. On these occasions, they claimed, the royal treasury took care of all expenses without demanding any contribution from the prelates. ${ }^{291}$

Facing stubborn resistance from the clerics, the Viceroy replied to their requests founding his argument on the Recopilacion de Leyes de Indias. ${ }^{292}$ He explained that according to one of laws in this corpus of royal legislation, the royal treasury must contribute with a third of the total cost of the construction of a new church. He argued that because of the extraordinary circumstances and the necessity of rebuilding the cathedral, the royal treasury would contribute only 20,000 pesos once the prelates secured the remaining 40,000 pesos. The Duke additionally offered two alternatives to obtain the needed funds. First, he suggested the reduction of expenses of the interior fábrica because 10,000 pesos of expenses each year were excessive and unnecessary. He recommended reducing expenses to 5,000 pesos, and using the rest of the funds for reconstruction works. Second, he suggested that the prelates offer individual donations and surrender for a few

\footnotetext{
${ }^{291}$ Petition of the Fiscal, March 21, 1688. Autos que tratan de las diligencias hechas con el Venerable Dean y Cavildo.

${ }^{292}$ Letter of the Viceroy Duke of Palata to the Dean and Ecclesiastical Council, April 6, 1688. Autos que tratan de las diligencias hechas con el Venerable Dean y Cavildo. The Viceroy specifically refered to the Ley 5, Titulo 2, Libro 1.
} 
years the salaries from vacant Church positions that they distributed among themselves to supplement to their own. In case the prelates were still unwilling to confirm their contribution of the 40,000 pesos, the Viceroy would then take the issue to the king. ${ }^{293}$

The ecclesiastical council responded that notifying the king and waiting for his resolution would only increase the expenses of the reconstruction because another quake, even less severe than the previous one, could shatter the cathedral and increase the repair costs. They also rejected the Viceroy’s interpretation of the law in the Recopilación, stating that it was applicable only in case of new foundations. Even if the law made reference to repairs in case of expansion, the council argued that these were the product of human initiative while the cathedral's condition was the product of divine intervention.

Confronted with this legal impasse, the prelates offered a solution derived from local practice and custom, which were "the best interpreter of the laws." ${ }^{294}$ They argued that previous viceroys had assigned financial support to the cathedral without informing the king in the first place. They considered any consultation with the monarch unnecessary because of the extraordinary circumstances the city. The renowned Catholic zeal of the

${ }^{293}$ Ibid.

${ }^{294}$ Response of the Cabildo to the Viceroy’s letter, April 22, 1688. Autos que tratan de las diligencias hechas con el Venerable Dean y Cavildo. 
king, who would not permit the cathedral to remain in disrepair, was enough justification to approve an immediate decision from the Viceroy. They again stated that the gobierno superior had supplied the repairs of the cathedral from the royal treasury at all times. In 1596, the royal administrators assigned 12,000 pesos to the cathedral's fábrica. In 1602, the government increased such amount to 18,000 pesos, which remained the allotted amount until 1626. The prelates also mentioned that the royal treasury assumed all expenses of repairing the cathedral after the earthquakes of 1655 and $1678 .{ }^{295}$ In addition to these practices, the religious ministers indicated that a royal decree of 1649 had instructed to Viceroy Conde de Salvatierra and the Archbishop Don Pedro de Villagómez to finish the construction of the cathedral's tower and portals. They concluded that if the

\footnotetext{
${ }^{295}$ Lavalle, Juan Antonio de, Domingo de Vivero, and Evaristo San Cristóbal. Galería de Retratos de los Gobernadores y Virreyes del Perú (1532-1824) (Lima: Librería Clásica y Científica, 1891), n.p. The first of these earthquakes was in January $5^{\text {th }} 1655$, during the government of the Viceroy Conde de Alva de Liste (1655-1661); Baltazar de la Cueva, "Relación General que el Excelentísimo Señor Conde de Castellar, Marques de Malagón, Gentil Hombre de la Cámara de su Majestad, de su Consejo, Cámara y Junta de Guerra de Indias, virrey, Governador y Capitán General que fué de estos reinos, hace del tiempo que los gobernó, estado en que los dejó, y lo obrado en las materias principals con toda distinction,” in Memorias de los Virreyes que han gobernado el Perú durante el tiempo del coloniaje español edited by Manuel Atanasio Fuentes (Lima: Librería Central de Felipe Bailly, 1859), 192. The second quake was on June 17, 1678, during the administration of the Count of Castellar.
} 
king had financed aesthetic works during those times, he would be willing to cover the necessary repairs the cathedral required. ${ }^{296}$

The ecclesiastical council's members concluded that they had no obligation to contribute to the rebuilding of the cathedral and that the Recopilación was not applicable because the royal decree of 1649 had endorsed the customary practice of the royal treasury, showing that the Spanish monarch voluntarily wanted to take care of such expenses. They also supported their argument with other legislation compiled in the Recopilación. ${ }^{297}$ Such laws stipulated that one-third of the cost of the construction works of a church should be funded by the royal treasure and another third should come from the encomenderos of the archdiocese's jurisdiction. With this argument, which combined practice and law, they concluded that the royal treasury was required to contribute two-thirds, or 40,000 pesos, of the total reconstruction costs. ${ }^{298}$

\footnotetext{
${ }^{296}$ Memorial of the Venerable Dean and Council; and Petition of the Fiscal, March 21 1688. Autos que tratan de las diligencias hechas con el Venerable Dean y Cavildo. The fiscal clarifies that the first royal concession was issued in 1598, to support the repairs the Cathedral needed after the earthquake of 1586.

${ }^{297}$ Memorial of the Venerable Dean and Council. Autos que tratan de las diligencias hechas con el Venerable Dean y Cavildo. indicates these laws were Leyes 2 and 3, Titulo 2, Libro 1.

${ }^{298}$ Ibid, indicates that Leyes 2, 3, and 5, Titulo 2, Libro 1, stipulated the Indians should afford the remaining third of the cost.
} 
The ecclesiastical council and the Archbishop also argued against each of the Viceroy’s suggestions for financing the rebuilding works. First, they argued that reducing the expenses of the interior fábrica from 10,000 to 5,000 pesos each year would decrease the decency of the mass celebration. They imagined the demoralizing effect it would have if the cathedral's interior looked the same as a poor parish. They suggested that the government should reinstitute a moribund tribute levied on natives because it was the "most natural” source of funds since the king originally instituted it. ${ }^{299}$ They also suggested that the espolios (estates of deceased prelates) of former Archbishop Don Pedro de Villagoméz, presently used for the assistance to convalescent priests and other pious works, should be appropriated. ${ }^{300}$ The prelates were not concerned that Indians, sick priests, and other needy individuals might suffer with the measures they proposed. They just wanted to erect the cathedral to its former grandeur and comply with their obligation of officiating the divine services. Nonetheless, even this was not important enough to deserve a sacrifice from their own funds.

\footnotetext{
${ }^{299}$ Ibid, the prelates were referring to the fee of one tomín (one real or one-eight of a peso) that Indian tributaries paid. Nonetheless, according to the Recopilación de Indias, Ley 7, Título 4, Libro 1, King Phillip IV instituted this fee in 1626 to provide funds for hospitals that would attend natives.

${ }^{300}$ Memorial of the Venerable Dean and Council, April 21, 1688. Autos que tratan de las diligencias hechas con el Venerable Dean y Cavildo.
} 
What is more, both the Archbishop and the members of the ecclesiastical council refused to give individual donations from their personal income. The prelates declared that the Archbishop was already burdened assisting the large number of poor people produced by the quake, that he was left with no funds to rebuild his own palace. The ecclesiastical counselors excused themselves arguing that the salaries they received were insufficient to afford the excessive cost of living in the city, and the assistance to their relatives and the poor. Even with the additional income they received from the vacant salaries, which they distributed by law and custom among the current prelates, they suffered the same "afflictions as the other needy persons in the city., 301 The dean argued that the condition of the ecclesiastical council's treasury was defficient because the tithes in the archdiocese had fallen in after the earthquake. ${ }^{302}$ Thus, the prelates finally resorted to asking the Viceroy to collaborate with the rebuilding of the cathedral from his personal fortune.

In order to initiate the rebuilding works of the cathedral, the Real Acuerdo ordered measures to obtain financial resources, taking into account the suggestions of the ecclesiastical council. They agreed to disburse from the royal treasury the 20,000 pesos

\footnotetext{
301 Ibid.

302 Actas del Cabildo Eclesiástico, ACL, f. 236, 236 v.
} 
belonging to the crown. They also accepted the plan to reinstitute the Indian tributaries' payment of the tomín, and assigned 3 percent of the encomiendas' rents that were not financing churches in their jurisdictions. ${ }^{303}$

Facing the prelates' refusal to contribute from their own incomes, the Duke decided to elevate the resolution of the matter to the King. He requested from steward Don Gabriel of Sumiano a report on the basic salary each of the prelates received. ${ }^{304}$ The steward's report showed the quantities that each prelate received for the period of five years, from 1683 to 1688 . The archbishop had an annual income that exceeded 32,000 pesos. ${ }^{305}$ This salary alone would cover half of the repairs the cathedral needed. The dean received more than 6,000 pesos; the dignitaries over 5,000 pesos; the canons surpassed 4,000 pesos; other prelates received 2,000 and 1,000 pesos. ${ }^{306}$ In all of these amounts, the members of the

\footnotetext{
${ }^{303}$ Auto of the Real Acuerdo, May 6, 1688. Autos que tratan de las diligencias hechas con el Venerable Dean y Cavildo.

${ }^{304}$ Letter of the Viceroy to the King, Lima, May 31, 1688. AGI, Lima 87.

${ }^{305}$ Navarra y Rocafull, “Memoria de Gobierno,” 19, 20, refers the archbishop’s income exceeded the amount of 40,000 pesos.

${ }^{306}$ Certification of the annual income of the Archbishop, Dignities, Canons, Prebendaries, and HalfPrebendaries, made by Don Gabriel Somiano, May 31, 1688. AGI, LIMA 87, did not include the amount the archbishop received from vacant salaries.
} 
ecclesiastical council received almost 60 percent more than their regular income because they distributed the salaries of unoccupied posts among themselves. Nonetheless, they felt they were as afflicted as the rest of the population and unable to offer personal contributions.

On his report to the King, the Viceroy suggested that the crown seek a bull from the pope for the use of the ecclesiastical council's vacant salaries towards the reconstruction of the Cathedral. He proposed that the concession should be extended for a period of at least twenty years or in perpetuity because "earthquakes were ordinary" in the viceroyalty. ${ }^{307}$ If the Pope agreed to award those funds in perpetuity, they should provide enough reserves for another natural disaster. The Council of Indies accepted the suggestion and requested the use of the vacant posts' funds from the Vatican. The Pope Innocent XI awarded to the royal administration the use for six years of the salaries of two vacant posts, which represented 36,000 pesos. ${ }^{308}$

\footnotetext{
307 Letter of the Duke of Palata to the King, May 31, 1688. AGI, Lima, 87. The viceroy used this opportunity to suggest the King that the tercias vacantes, the third part of the vacant salaries, which the bishops received in addition to their regular congrua, should be dedicated to for the repair and ornament of provincial church, which were constantly claiming assistance for repairs.

${ }^{308}$ Letter of the Marquis of Copolludo to the King, Rome, January 23, 1689. AGI, Lima 87. The Pope also granted a forth part of the following post that would become vacant.
} 
By the time the bull authorizing the use of the vacant salaries in the reconstruction of the cathedral arrived in Lima, the Duke of Palata had already ceded power to the next viceroy, Count of Monclova. Nonetheless, his negotiations with the ecclesiastical council and the efforts by fiscal were noteworthy because they provided enough information to support his request to the King. If it is true that his success was only partial because he did not obtain the concession to secure funds for twenty years or in perpetuity, he was ultimately able to reduce the obligations of the royal treasury and compel the prelates to contribute to the reconstruction of the cathedral.

The members of the ecclesiastical council finally had to financially support the rebuilding works in the cathedral. The expenses of the repairs surpassed the 60,000 pesos that were initially calculated, and the prelates had to provide additional funds from their own budgets in order to continue the construction project. ${ }^{309}$ Sources offer no information about the implementation of the fees the Royal Acuerdo had agreed to extend to Indians and encomenderos, yet they do corroborate that the salary of the vacant post were finally used to rebuild the cathedral.

\footnotetext{
${ }^{309}$ Actas del Cabildo Eclesiástico, ACL, f. 105. The archbishop provided 2,000 pesos, and all members of the ecclesiastical council 5,000.
} 
The prelates were so affected by the reduction of their income and the need to provide personal donations for the rebuilding works that they requested the King not repeat the measure. They argued that the vacant posts offered them a necessary supplement to their regular income because they were overburdened assisting their families and the poor. At the same time, they had the responsibility of living "with the decency that the post [of dignitaries] required" in a city that "was head of the kingdom." 310 In other words, they deemed their salaries inadequate to fulfill their charitable activities and live according to the standards of their positions.

\section{The Head against the Body}

Despite the image of unity the ecclesiastical council and the Archbishop showed during the discussion about how to rebuild the cathedral, the highest echelons of the secular church’s hierarchy were far from homogeneous. Even though on some occasions they seemed to pursue similar interests--as when they resisted financially supporting the reconstruction of their church or when they repelled the Viceroy's attempt against the ecclesiastical immunity--the Archbishop and members of the ecclesiastical community were far from a cohesive body. They certainly shared similar perceptions about the royal

\footnotetext{
${ }^{310}$ Ibid, f. 105v.
} 
government and its duties towards the church, yet the ecclesiastical council was a group with similar interests that usually intervened to moderate the archbishop's antipathy towards the viceroy. ${ }^{311}$

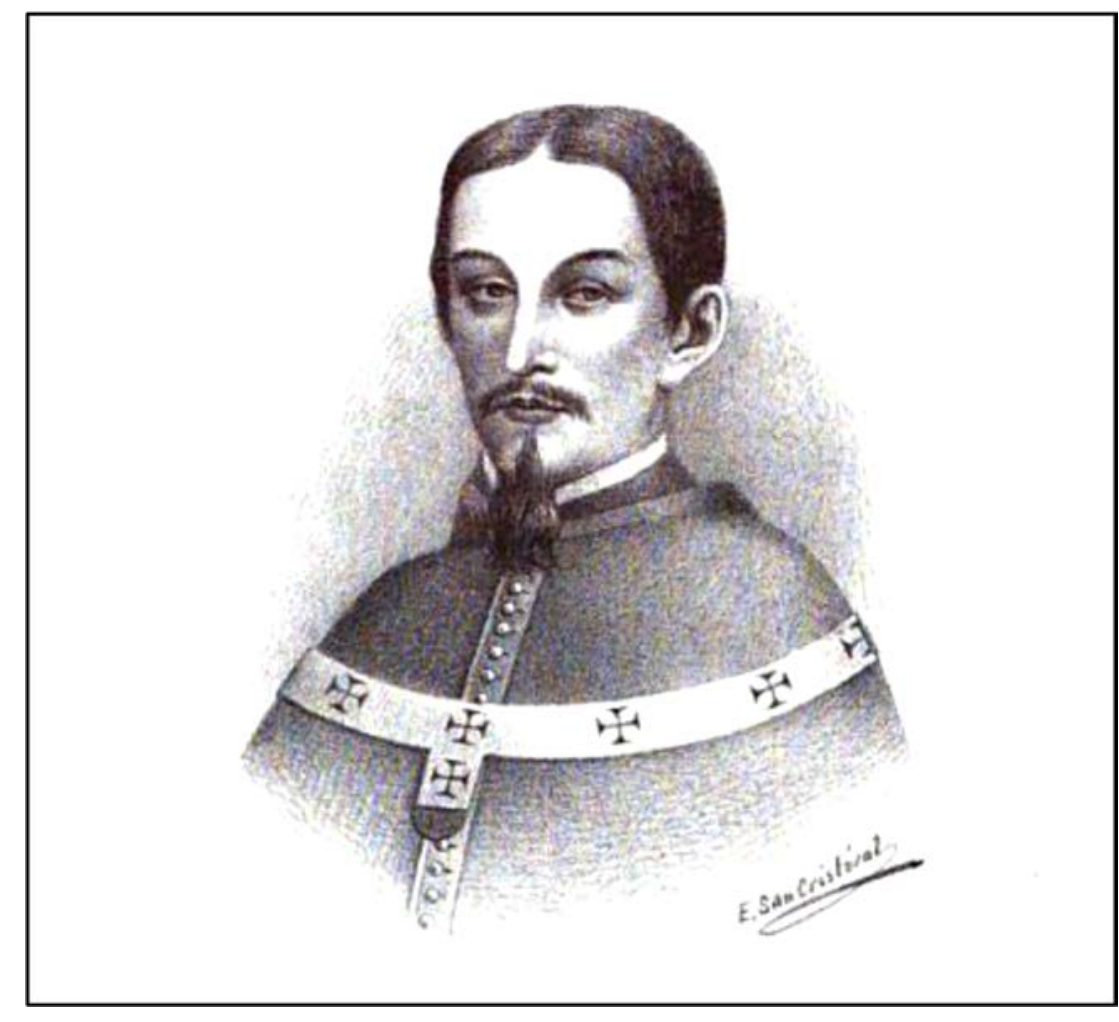

Image 13: Archbishop Don Melchor de Liñán y Cisneros ${ }^{312}$

During the weeks following the earthquake, the Archbishop became mainly concerned with the rebuilding of his palace, located in the same block as the cathedral.

\footnotetext{
${ }^{311}$ Crahan, “Clerical Immunity in the Viceroyalty of Peru, 1684-1692.” Examining the viceroy’s attempts to limit the priests' mistreatment of Indians through his decree of February 21, 1684, the author demonstrates how the council mediated a rapprochement between the viceroy and the archbishop.

${ }^{312}$ Lavalle, Vivero, and San Cristóbal. Galería de Retratos de los Gobernadores y Virreyes del Perú, n.p.
} 
When he refused to contribute to the reconstruction of the cathedral, he had declared he was willing to halt the reconstruction of his palace in order to financially assist the poor. Nonetheless, he diligently sought the initiation of the repairs of his residence. He sent his steward, Don Francisco de Jauregui, to request funds from the ecclesiastical council to the cover of the repairs of the archbishopric palace. The Archbishop claimed that he had already spent 20,000 pesos on his palace by the time he established residence in it, and an additional amount after the previous Earthquake of $1678 .{ }^{313}$

Confronted with this demand, the members of the council protested the Archbishop’s actions. The Dean Don Luis José Merlo de la Fuente responded that the Archbishop's request was contradictory because, as head of the Church, the Archbishop was the highest judge in the ecclesiastical court and could not be a petitioner at the same time. Merlo also emphasized that the archbishop had only complied with his duties when repairing his own palace. Additionally, he indicated that the treasury of the archbishopric and the ecclesiastical council were depleted because the earthquake had considerably reduced the tithes of the archdiocese. He argued that the Archbishop should pay for the reparations of his residence, as other prelates had traditionally done. Thus, the dean

${ }^{313}$ Actas del Cabildo Eclesiástico, ACL, f. 235. 
concluded that the church's treasury required relief and assistance rather than more burdens. Merlo also enumerated some of the measures taken by the ecclesiastical council to reduce the cathedral's expenses such as reducing the salary of the singers, and the amount of wax used commonly for the Virgen of the Candelaria festivity. The ecclesiastical council recommended that the Archbishop proceed similarly by tightening his belt and making reductions to his own budget. ${ }^{314}$

In the following meetings of the ecclesiastical council, the dean openly criticized the Archbishop. He stated that it was a "monstrosity that the head [the archbishop] proceed against its members [the ecclesiastical council].”315 Despite these initial conflicts between the archbishop and the council, the repairs to the archbishopric palace began after a year and a half of negotiation. ${ }^{316}$ Liñán y Cisneros persisted in demanding his return to the palace so he could remain close to the cathedral, administer regular religious functions, and

\footnotetext{
${ }^{314} \mathrm{Ibid}, \mathrm{f} .236,236 \mathrm{v}$. The archbishopric's treasury had already disbursed 20,000 pesos to cover the repairs of the ecclesiastical palace. This amount includes 14,000 spent to make some repairs before the archbishop moved into the palace and 6,000 expended to fix some damages produced in this property by the earthquake.

${ }^{315}$ Ibid, f. 239 v, “es monstruosidad que la cabeza proceda contra sus miembros.”

${ }^{316}$ Memoria de los gastos que se ban haciendo en la obra del Palacio Arçobispal por Pedro de Guadalupe, January 7, 1690. ACL, Cuentas de Fabrica, Carpeta 14.
} 
maintain the government of religious matters. The prelates finally agreed to sell the principal of some censos in order to obtain the 10,000 pesos necessary for the reconstruction of the archbishop's palace. ${ }^{317}$ Nonetheless, this amount was exhausted in a few months. The Archbishop had to request one more time that the ecclesiastical council impose in censo any principal it had in its power in order to to obtain the money to finance the remaining repairs in his palace. ${ }^{318}$

When the Archbishop offered to give up his personal belongings to the poor rather than use them to finance the reconstruction of his palace, he was apparently attempting to avoid contributing financially in the cathedral's rebuilding. The reconstruction of the archbishop's palace was his main goal because he decided to demand that the ecclesiastical council provide funds for its reconstruction, without considering the economic condition of the council and the financial acrobatics its members would have to perform in order to obtain the needed resources.

\section{Conclusion}

\footnotetext{
${ }^{317}$ Actas del Cabildo Eclesiástico, ACL, f. 74v.

${ }^{318}$ Ibid, f. 110.
} 
The evidence in this chapter shows that regular and the secular clergies had different reactions and interests at stake, and as a result performed differently in the aftermath of the earthquake. The religious orders diligently organized and participated in different activities of spiritual relief and exhortation. They also had an active role financing and organizing the reconstruction of their properties, which were among the most affected in the city.

Some of the religious orders also joined the Viceroy in the penitence activities he organized and led. The Viceroy played a central role in these demonstrations of repentance. He took advantage of the absence of the Archbishop to appear as the leading figure of the reconstruction of Lima. The Archbishop was so weak after almost dying in the quake and tsunami that he was unable to participate in the construction activities of limeños, yet he was not sick enough to participate in the negotiations over the cathedral's reconstruction. The actions of the Archbishop were incompatible with the role most religious and civil people expected him to play. It was evident that he was more concerned with preserving his personal interests than performing his duties as head of the colonial church.

The members of ecclesiastical council were as stubborn as the Archbishop in refusing to cede part of their personal incomes for the reconstruction of their church. They 
elaborated a counter-argument to the Viceroy’s use of a law in the Recopilación de Indias, and used written law to ratify a customary practice, where law merely ratified customary practice that would alleviate some of the burdens on their finances. Throughout the long debate regarding the reconstruction of the cathedral, they constantly emphasized the obligation of the Spanish monarch, as regal patron, to pay for the whole rebuilding of the church. Nonetheless, it is evident that their final objective was to keep the additional funds they received as salaries from the vacant posts.

Even though they were a solid and unanimous faction when opposing the financial demands of the Viceroy, the conflicts between the Archbishop and the ecclesiastical council demonstrate the internal fractures of the ecclesiastical hierarchy. Both the Archbishop and members of the ecclesiastical chapter fought against providing money from their own fortunes for the cathedral's reconstruction. For this reason, the Archbishop tried to get the cathedral's building fund to pay for the reconstruction of his palace, and he, along with the members of the council, tried to evade the obligation to rebuild and pass it on to the royal treasury. Temporal interests were apparently more important than the spiritual ones for most of the distinguished prelates in Lima. 
In the end, the colonial administration was able to overcome the obstinacy of the prelates and obtain the funds to rebuild the cathedral. Despite the lack of cooperation from high-ranking members of the secular church, most religious men and women contributed to the reconstruction of the city, willingly or unwillingly. Religious and administrative buildings were greatly damaged by the earthquake but these were not the only ones to suffer damage. Most of the properties affected housed ordinary inhabitants of the city, even many were owned by church clergy. Therefore, the reconstruction of the city would require the extensive participation of ordinary people.

\title{
V. CHAPTER 4: FROM THE BOTTOM UP: RECONSTRUCTING LIMA
}

\author{
AFTER THE 1687 EARTHQUAKE
}


In the wake of the 1687, Lima's royal agents prioritized the reconstruction of administrative and religious buildings. In spite of the poor condition of the royal treasury and the secular clergy's reluctance to collaborate with the repair project, colonial administrators successfully initiated a reconstruction project for Lima’s main buildings. But royal authorities were not the only ones working to rebuild the fallen city. Lima's residents- far from being passive observers-- participated actively in the reconstruction tasks. Through negotiation in both official and unofficial spheres, they recreated, reinforced, and legitimated the creative, contractual nature of the early modern state. Contrary to modern states, in which mandates tend to be given from a centralized locus of government, the Spanish empire instead featured multiple sites of authority and contention. ${ }^{319}$ The initiatives and practices the Spanish crown introduced in the New World developed into a collective set of values among its colonial subjects, who

\footnotetext{
${ }^{319}$ Alan Knight, "Weapons and Arches in the Mexican Revolutionary Landscape," Everyday Forms of State Formation, 24-66; William Roseberry, “Hegemony and the Language of Contention,” Everyday Forms of State Formation, 355-366; Miguel Angel Centeno and Agustin E. Ferraro, State and Nation Making in Latin America and Spain: Republics of the Possible (New York: Cambridge University Press, 2013).
} 
reproduced colonial culture through specific practices that legitimated metropolitan authority. ${ }^{320}$

This chapter demonstrates that ordinary residents adapted and indeed recreated the Spanish colonial legal system through reconstruction initiatives. The examination of formal contracts and informal agreements shows the Spanish colonial regime penetrated the everyday lives of colonial subjects. Consciously or not, when subjects adopted colonial legal practices, they legitimized or confirmed the authority of the colonial government.

They were not merely performers of these forms of rule, but also innovators, adapting them according to their needs and the circumstances of the city. Documentation produced inside and outside the courtroom reveals limeños' use and adoption of the Spanish practices and rules around contract-making, and how important contracts were to their reconstruction efforts and everyday activities. Lima’s post-disaster contracts reveal how the city’s diverse population resorted to legal contracting, official negotiation, and unofficial agreements in order to rebuild their properties. These contracts, both official and extra-official, also show how people understood and applied ordinary precepts and

\footnotetext{
${ }^{320}$ Michael Foucault, “Govermentality,” 87 - 104; Corrigan and Sayer, The Great Arch, 4, 9; Braddick, State Formation in Early Modern England, 9.
} 
practices of the Spanish legal system in an unexpected and extraordinary post-disaster

context.

Even though the 1687 earthquake interrupted most of the daily political, social, cultural and economic activities, the authority of the Spanish colonial administration in Lima remained virtually unopposed. In fact, through their reconstruction initiatives, Lima's inhabitants reinforced the authority of the Spanish administration.

The participation of people of different social status and their use of state institutions, rituals, and rules were essential components of an ongoing process of configuring and legitimizing the colonial project. ${ }^{321}$

\section{Renters and Owners}

With the daylight that broke hours after the quake, residents recognized the magnitude of the destruction. Convents, monasteries, and churches were most damaged.

Governmental buildings, too, required repairs or even complete reconstruction. ${ }^{322}$ Not

\footnotetext{
${ }^{321}$ Bianca Premo, Children of the Father King. Youth, Authority and Legal Minority in Colonial Lima (Chapel Hill: The University of North Carolina Press, 2005), 44. Tamar Herzog, Upholding Justice: society, state, and the penal system in Quito (1650-1750) (Ann Arbor: University of Michigan Press, 2004), 9.

${ }^{322}$ Manuel de Mendiburu. Diccionario Histórico - Biográfico del Perú, vol. 8, 102; Account of the City Council, by Diego Fernández Montaño, 9v. Many religious men and women died in their cloisters, under the debris of the building structures. Only the Chapel of El Sagrario remained standing, although nobody
} 
even homes and commercial spaces were spared. Proprietors had the onerous task of covering the high cost of repairs. The Viceroy reported that while most private residences remained standing, they were drastically affected and required extensive repairs. ${ }^{323}$

In the weeks and months following the destructive event, government activities increased. Royal authorities supervised food distribution, implemented social control measures, and planned reconstruction projects. They decreed price controls on building supplies and construction wages. ${ }^{324}$ Recognizing that residents would face high repair costs, the Viceroy attempted to regulate those products to safeguard the interests of private parties, both corporations and individuals. Nevertheless, constructions costs were not the only problems private interests faced.

dared to enter inside. Judith Mansilla, "Poder y prestigio social en las cofradías de españoles, siglos XVII y XVIII," in Corporaciones religiosas y Evangelización en Ibero - América. Siglos XVI - XVII, edited by Diego Lévano and Kelly Montoya(Lima, Universidad Nacional Mayor de San Marcos, 2001), 114 - 116. The Cathedral, and the archbishop's palace, and the City Hall were greatly damaged. The viceregal palace was completely shattered that royal administrators decided to rebuild it completely. Both royal and the religious authorities of the Lima had to confront with the onerous reconstructions of their headquarters, rebuilding tasks that were not exempted of difficulties.

${ }^{323}$ Letter of the Duque of Palata to the King, Lima, December 8, 1987. BNM, MS 9375.

${ }^{324}$ Actas del Cabildo de Lima, f. 161 v, 170 v, 173. 
The destruction of buildings halted the colonial economy since so many of these structures provided rents to owners or other beneficiaries. In the destruction of any given residential space, owners saw a reduction in income: occupants either refused to pay rent for the damaged quarters or even abandoned these spaces. For proprietors relying heavily on rent proceeds, raising money to pay for reconstruction became a real challenge. In order to resolve the conflicts resulting from these conditions, people in Lima made various types of contracts. These demonstrate the extent to which the Spanish legal system penetrated various levels of colonial society.

The Spanish colonial legal system had an extensive bureaucracy and overlapping jurisdictions that operated cohesively during the earthquake’s aftermath. ${ }^{325}$ The broad destruction of the city put this bureaucratic machinery in Lima into motion. In the months after the quake, high-level officials such as cabildo members, the Viceroy, judges, and

\footnotetext{
${ }^{325}$ It is not the purpose of this dissertation to discuss the extension and complexity of the Spanish legal system, but to show that this machinery offered Lima's royal officers and population the means to rebuild the city and the political system. Treatments of the legal system abound. See, for example, Tamar Herzog, Upholding Justice; Lauren Benton, Law and Colonial Cultures. Legal Regimes in World History, 1400 1900 (Cambridge: Cambridge University Press, 2002), 33-45; John Leddy Phelan, “Authority and Flexibility in the Spanish Imperial Bureaucracy,” Administrative Science Quarterly, Vol. 5, No.1 (Jun., 1960), 47-65; Víctor Gayol, Laberintos de justicia: Procuradores, escribanos, y oficiales de la Real Audiencia de México (1750-1812), Vol. I (Zamora: El Colegio de Michoacán, 2007), illustrate the complexity of the Spanish legal system.
} 
notaries also came to assist in the reconstruction effort. The resulting legal transactions

left diverse documentation showing how limeños sought the intervention of these colonial authorities in order to settle conflicts, validate agreements, and tend to other specific needs.

A large part of Lima's residents paid for the spaces they used for housing and working, even if they owned such places. Many of the properties in Lima had different economic burdens such as liens (censos) and future religious obligations placed on property (capellanía). ${ }^{326}$ Censos were the most frequent economic impositions on real estate. They were disguised forms of money loans secured against real estate. The censatario (censo borrower) had to annually pay a small percentage of the principal to the censualista (loan lender). ${ }^{327}$ A capellanía was a perpetual bequest instituted when

\footnotetext{
${ }^{326}$ Alfonso Quiroz, "Reassessing the Role of Credit in Late Colonial Peru: Censos, Escrituras, and Imposiciones,” Hispanic American Historical Review 74, 2 (May, 1994), 196, defines censos as one of the main sources of credit in the colonial period. They were a type of mortgage loans that looked as sale or lease contracts of properties. The owners received monetary advancements from a person or institution that had currency at hand, and secured such loans with their real state properties. For more information about census refer to Javier Augusto Espinoza Ríos, “Las Finanzas el Fervor. Las Prácticas económicas en el Monasterio de Santa Clara de Lima, 1621-1682” (MA Thesis, Pontificia Universidad Católica del Perú, 2012).

${ }^{327}$ Censos were not a single mechanism of economic obligation. Quiroz, "Reassessing the Role of Credit in Late Colonial Peru,” 197, states that there were three common types of censos: enfitéutico, reservativo, and consignativo. The first of them was a kind of loan-lease where the borrower or censatario paid some réditos
} 
landowners commanded their heirs to pay for religious services to save their souls. ${ }^{328}$

Together, censos and capellanías represented a heavy toll on tenants and property owners

whose economic capacity became limited after the earthquake’s assault.

The principal censualistas were religious institutions including monasteries and

convents. Religious corporations were the largest real estate holders and had access to

currency from the laity's various bequests. ${ }^{329}$ They rented real estate properties or

advanced cash through censo contracts. In both cases, they received a fixed annuity

(interests or annuity) to the borrower or censualista. Because it could last a lifetime, the censo enfitéutico was also known as perpetuo or irredimible. The second type, the censo reservativo, was a loan-sale contract that specified a fixed rent to the lender or censatario. The last one, the consignativo was more specifically a loan that the debtor could redeem. In the meantime, he must pay to the lender some interests or réditos. Because of its repayable nature, this kind of censo was also known as al quitar or redimibles.

${ }^{328}$ Gisela Von Wobeser, “La Función Social y Económica de las Capellanías de Misas en la Nueva España del siglo XVIII,” Cofradías, Capellanías y Obras Pías en la América Colonial, edited by Pilar Martínez López-Cano, Gisela Von Wobeser, and Juan Guillermo Muñóz, 119-138 (Mexico: Universidad Nacional Autónoma de México, 1998).

${ }^{329}$ Elliot, Empires of the Atlantic World. Britain and Spain in America, 202, states the Church owed massive extensions of properties. The various branches of the church possessed around 47 percent of urban property in Mexico City by the end of the colonial period. In Peru, during the seventeenth century, the church was the major proprietor and credit supplier. 
secured on real estate. Censos were profitable and secure investments of capital, for that reason they became common in the colonial economy. ${ }^{330}$

Confraternities were another important group among the beneficiaries of censos

because they had access to both property and specie. These religious brotherhoods gathered laypeople together to venerate Christ, the Virgin, and other saints. Although religious in their objectives, the confraternities also played an economic role in the community, thanks to cash gathered from alms, donations, and membership fees. ${ }^{331}$

${ }^{330}$ Asunción Lavrin, “El Capital Eclesiástico y Las Elites Sociales en Nueva España a fines del XVIII,” Mexican Studies/Estudios Mexicanos 1, № 1 (Winter, 1985), 2.

${ }^{331}$ Inmaculada, Arias de Saavedra, Miguel Luis López, and Guadalupe Muñoz, “Las cofradías y su dimensión social en la España del Antiguo Régimen,” Cuadernos de Historia Moderna, 25, (2000): 189232, argue that state confraternities gave their members a social space in which to establish bonds of friendship, comradeship and even kinship. For more information about the various activities confraternities developed see Diego Lévano, “Organización y Funcionalidad de las Cofradías Urbanas. Limas siglo XVIII,” Revista del Archivo general de la Nación, 22 (2001): 77-118; Guillermo Lohmann Villena, “La Ilustre Hermandad de Nuestra Señora de Aranzazu de Lima," in Los vascos y América. Ideas, hechos, hombres. Actas de las Jornadas sobre el comercio vasco con América en el siglo XVIII, y la Real Compañía Guipuzcoana de Caracas en el II Centenario de Carlos III, 203-213. Madrid: Fundación Banco de Bilbao y Vizcaya, 1990; Jesús Paniagua, “Cofradías Limeñas: San Eloy y la Misericordia (1597-1733),” Anuario de Estudios Americanos, LII-1 (1995): 13-35. Albert, Meyers, "Religious Brotherhoods in Latin America,” Manipulating the Saints: Religious Brotherhoods and Social Integration in Postcolonial Latin America edited by Albert Meyer and Diane Hopkins, 1-21 (Hamburg: Wayasbah, 1988); Joaquín Rodríguez, “Las cofradías de Perú en la modernidad y el espíritu de la Contrarreforma”, Anuario de Estudios Americanos, LII-2, Sevilla, 1995, 15 - 43; Walter Vega, “Manifestaciones religiosas tempranas: cofradías de negros en Lima. S. XVI”, Historia y Cultura, n 24, Lima, 2001; “Cofradías Limeñas”, en Laura Gutiérrez (ed.): Lima en el siglo XVI (Lima: PUCP/ IRA, 2005). 
The destruction of private buildings affected both censualistas and censatarios, many of whom faced repair costs without the means to cover sudden expenses. Although some religious institutions had currency to pay for the reconstruction of properties, most proprietors-- both corporate bodies and individuals-- lacked the necessary resources. Some cases aired before Lima's courts show that conflicts originated between two or more parties when properties lost value because of the extensive damage after the earthquake. Many censatarios abandoned the properties and stopped the payments of censos' interests and other rents the properties held. In other cases, censatarios tried to get a reduction of the periodical rents, either the principal or the interests, they paid to the owners or administrators of the properties they occupied.

The destruction of building properties in the city not only affected tenants and owners, but also capellanes or beneficiaries of capellanías. In exchange for delivering masses for the soul of the capellania's founder and immediate relatives, these priests received a fixed rent. Various capellanes saw part of their income reduced because many buildings were often burdened with capellanías. ${ }^{332}$

\footnotetext{
${ }^{332}$ Capellanías were legacies that have the main objective of maintaining religious services to redeem the founder's soul. Secondarily, they also provided a regular rent or income to the priest in charge of celebrating such services, who was commonly a close relative of the founder.
} 
In the two following cases, administrators of damaged properties requested the Judge of Legados, Testamentos y Obras Pías to authorize reconstruction projects that would economically affect the beneficiaries of capellanías, who had a claim on the income from these properties. A few months after the quake, Don Francisco de Velasco, steward of the confraternity of the Santísimo Sacramento and administrator of the chaplaincies founded by Juan Domínguez de Esquivel, presented a petition before the judge Don Juan de Mansilla. Velasco explained that the properties that provided the rent for the capellanías he administered were so greatly damaged that they were uninhabitable. He was concerned that, because of the lack of rent, the chaplain might discontinue the masses imposed by the pious foundation. The steward requested license to lease the properties on censo in order to obtain the funds to cover the repairs. He specifically demanded that the chaplain should not receive any rent until the properties were restored. ${ }^{333}$ In this case, both the confraternity, as owner of the properties, and the capellán, who benefited from the rents, were directly affected by the damage to those estates. The administrator asked that the judge compel the chaplain to share the temporary loss of income with the property owner.

${ }^{333}$ AAL, Cofradías, LII: 27, 1688, f. 1 v - 3 v. 
In a similar case, the administrators of the confraternity of Nuestra Señora de la Limpia Concepción, Alonso Pérez Campos and Pedro de Larreta, presented a request before the same judge. They indicated that the Licenciado Juan Reales had bestowed on the confraternity a house burdened with two capellanías, one for the benefit of Fray Joseph Buendía, and the other for Fray Nicolás de la Cerva. The earthquake had inflicted so much damage to the property that it became unoccupied, thus ceasing to produce the rent that paid the chaplains. They asked permission to repair the house, specifying the friars might abstain from receiving any rent during the time of the property reconstruction. ${ }^{334}$ Once both chaplains consented to the petition of the administrators, the judge issued the license to proceed with the repairs. ${ }^{335}$

The difference in the two cases just discussed is notable. In the first case, the administrator had asked the judge to compel the chaplain to accept his reconstruction project. In the second, the judge required the chaplains’ consent. Three administrators presented their projects before the judge in order to obtain permission to implement them. Yet, unlike Velasco, who showed no interest in knowing the chaplain's opinion, Perez

\footnotetext{
${ }^{334}$ AAL, Cofradía, IV: 19, 1688, f. 1.

${ }^{335}$ Ibid, f. 6 v.
} 
and Larreta asked the judge to endorse their project in order to present it to the chaplains for consideration. It seems Perez and Larreta's legal move, which demonstrated they were willing to negotiate and settle a "conveniente" agreement with the chaplains who were most effected by the earthquake, was positive. The repair works began a couple of weeks after Larreta and Perez presented their request, and the judge finally confirmed their project.

\section{Taking Plans to Court}

The two previous cases illustrate strategies proprietors and administrators used to hasten the rebuilding of damaged properties. In the months following the earthquake, residents of Lima from diverse social backgrounds came before the judicial forums to request permission to implement their own reconstruction plans. Petitioners designed their own rebuilding schemes and presented them before judges, who intermediated in the process of reaching a final agreement and getting the city up and running again.

Negotiation before the courts was expensive and usually a long process, which frequently did not result in a final sentence. Yet, if the parties collaborated in the negotiation process, they could avoid large expenses and waste of time. Ten months after the earthquake destroyed his home, Licenciado Don Juan de Villena proposed before Don 
Juan de Mansilla, Juez de Testamentos, Legados y Obras Pías, a series of changes to the censo contract on the house where he lived in. ${ }^{336}$ Villena explained that the house belonged to the confraternity of the Limpia Concepción, but he had been granted lifelong possession. ${ }^{337}$ The house was so badly damaged that he had to spend 700 pesos in various urgent repairs. In his petition, Villena offered to cover the works the property still needed if the administrators of the Limpia Concepción granted him the tenancy in the house for “three lives”-- meaning his own and two subsequent generations of his heirs. ${ }^{338}$ The administrators, Alonso Pérez Campos and Pedro de Larreta accepted the offer to avoid the time and expenses of a legal suit. They additionally demanded that Villena should rebuild the house according to the conditions stated in the original contract, which he signed at the time of receiving the house. The tenant would also need to continue paying the same annual rent without receiving any reduction, even though he had already spent a considerable amount of money in repairs. 339

\footnotetext{
336 AAL, Series Cofradías, IV: 18, 1688, f. 1.

337 This was a case of censo enfitéutico where Villena leased the property for 'una vida' (his timelife). In other words, the current contract will end at the time of his death.

${ }^{338}$ With this request, Villena was trying to extend the period of time their descendants would usufruct the property. AAL, Cofradías IV: 18, 1688, f. 1v.

${ }^{339}$ AAL, Cofradías IV: 18, 1688, f. 4.
} 
The back-and-forth interchange of conditions demonstrates both parties actively contributed to shape the final outcome of the process. Even when the administrators were willing to negotiate with the tenant, they tried to add to the contract provisions that were beneficial for the institution they represented. Villena accepted the extra conditions demanded by the administrators only if they agreed to consider his wife's life and his own as a single one because he was already 50 years old. Once the administrators consented to Villena's new petition, judge Mansilla ordered the petitioner to present three witnesses that would declare the agreement benefits for both parties. ${ }^{340}$ The three witnesses were Juan Ramírez de Vergara, Pedro de Elzagaza, and Lieutenant Don Alonso de los Cameros. They testified that the house that Villena had in possession belonged to the confraternity, and ratified that Villena's proposal was beneficial in that it spared the congregation of having to pay for the repairs or forgo annual rent. Two months after receiving the petition, Mansilla licensed the confraternity administrators to renew the written concession of residence according to the agreed-upon conditions. ${ }^{341}$ Here, the

\footnotetext{
${ }^{340}$ With this move, Villena was ensuring their children and grandchildren could continue living in the property, benefitting from the repairs and improvement in the house AAL, Cofradía IV: 18 (12f.), 1688, f. $6 v-7$.

${ }^{341}$ AAL, Cofradías IV: 18, 1688, f. 8v- 11.
} 
cooperation of both parties enabled a quick agreement. Likewise, the judge's assistance hastened a judicial process that could otherwise take several month or even years.

Similar negotiations greatly helped cases of multiple parties affected by the destruction of a single property. Agreements circumvented protracted disputes, cut court costs, and, in catalyzing reconstruction, avoided additional economic detriment to the damaged property. In such occasions, court procedures led to the ratification of the parties' final arrangement and, most important, facilitated resident's own efforts to share the burden of reconstruction.

Of course, not everyone negotiated cooperatively. In many cases, opponents disputed the legitimacy of contracts, citing the extraordinary conditions in which the city was living. This occurred in the case of Captain Don Gonzalo Andrés de Meneses against the Monasterio de la Concepción. ${ }^{342}$ Nine months after the calamity, the captain presented a petition before the Licenciado Francisco de Cisnero, Provisor and Vicario General of the Archbishopric, requesting a discount in the annual rent he paid to the monastery of Concepción for one of its houses, located in the Pescadería Street, which he had on lien. Meneses explained that the earthquake had affected both stories of the two-

${ }^{342}$ AAL, Cofradías, XXV: 38, 1688, f. 1 
level property and some rooms collapsed. He spent 500 pesos to pay the wages of the laborers that removed the debris and secured both floors. He asked the judge to appoint a construction master who could verify that such works had been made on the property. Because of these costs and the additional repairs that the property needed, Meneses attempted to obtain a reduction of the rent he paid by the property he occupied.

The monastery rejected Meneses’ request even though he demonstrated the ruinous condition of the property and the large expenses he had already incurred in fixing it and would have to incur in the future to prevent further damage in the property. By order of the judge, father Fray Diego Maroto of the order of Santo Domingo, maestro mayor de fábrica (construction master), visited the property and assessed the expenses of the works made in the monastery's house at 3,572 pesos. This amount represented the repairs the property still needed, so they were additional to the 500 pesos that Meneses declared he had already spent in some essential repairs. ${ }^{343}$ The representative of the monastery, Don Francisco Gomes de Ortiz, replied that Meneses was responsible for "maintaining the property [in good condition] regardless of any tremor" according to the

\footnotetext{
${ }^{343}$ Meneses declared he spent such 500 pesos on paying daily wages to the laborers that secured the roof and some walls that were prone to collapse in any moment. AAL, Cofradías, XXV: 38, 1688, f. 2 - 4.
} 
notarial contract.$^{344}$ The censatario claimed that the property was so damaged that he had to rebuild it almost entirely, and that the contract did not stipulate he must "rebuild it [the house] from its foundations.” ${ }^{345} \mathrm{He}$ offered to cover up to 4,000 pesos of expenses in exchange of a reduction of 50 percent of the annual rent. If the opponent part rejected his proposal, he requested permission to dissolve the contract so the monastery could rent it to someone willing to pay the entire annual rent of 1,200 demanded by the owner. ${ }^{346}$ The monastery refused to accept any of these options, arguing that Meneses would just be fulfilling his responsibility according to the contract. ${ }^{347}$ There was not a final resolution in this case; at least, it was not registered in the court record. It is possible that both parties were unable to reach a formal resolution. Meneses could either desist from fighting against the monastery, which had probably more resources at court, or look for alternative jurisdictional venues to challenge the stubbornness of his opponent. There was also the possibility that both parties reached an agreement outside the courtroom.

\footnotetext{
${ }^{344}$ Ibíd, f. 10.

345 Ibíd, f. 11.

${ }^{346}$ AAL, Cofradías, XXV: 38, 1688, f. 10 - 12.

${ }^{347}$ AAL, Cofradías, XXV: 38, 1688, f. 27 v.
} 


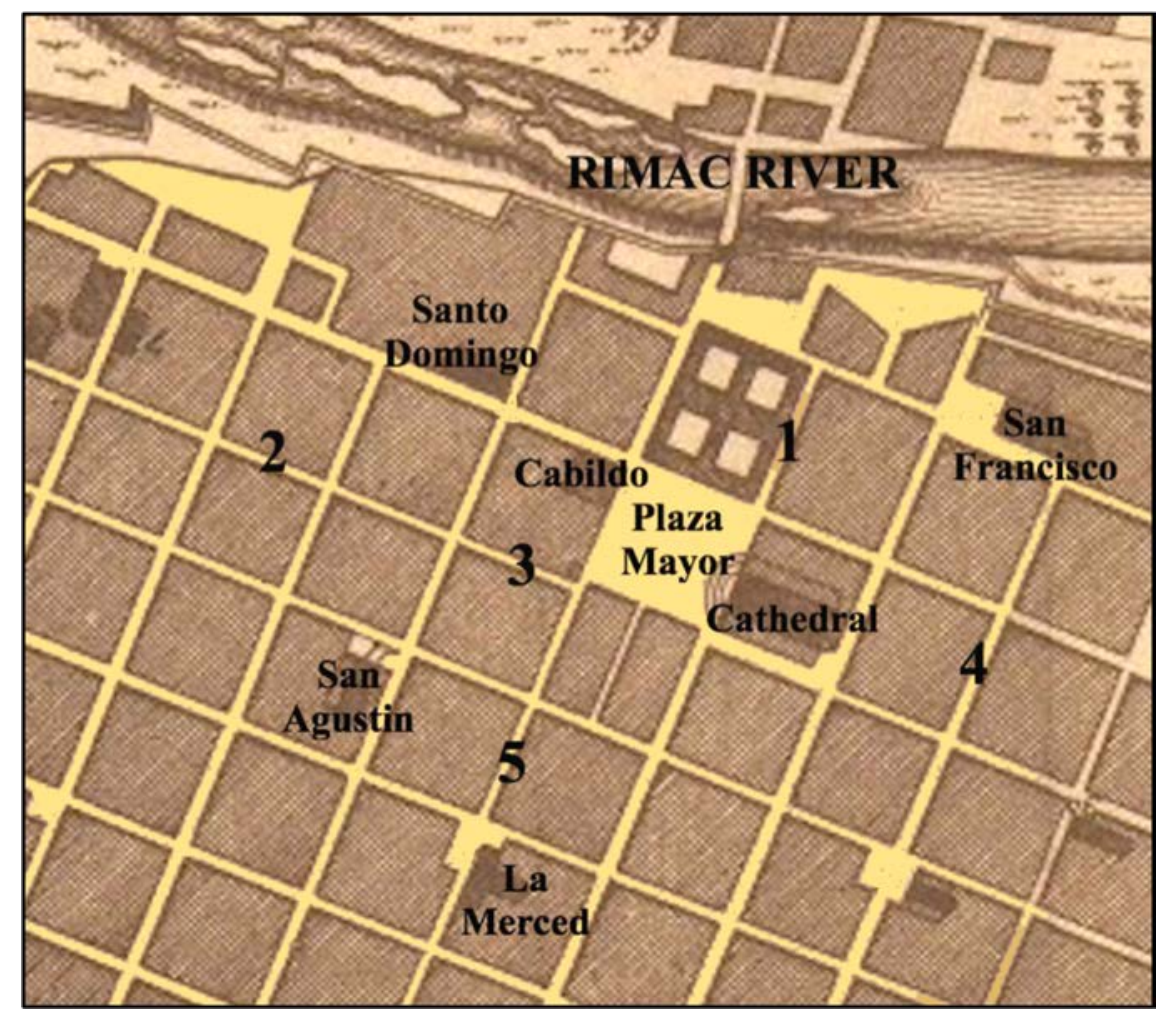

Image 14: Approximate location of some of the private properties. 1. Pescadería

Street, 2. Mármol de Bronce Street, 3. Mantas Street, 4. Aldabas Street, and 5. Espaderos Street. ${ }^{348}$

Along with official resolutions, there were out-of-court agreements that mirrored the official ones. An illustration of this type of settlement was the one between the Colegio de Nuestra Señora de Guadalupe, of the order of San Francisco, and the heirs of

\footnotetext{
${ }^{348}$ Location of these properties has been reconstructed by the author from descriptions available in the documents. 1. The houses that Gonzálo Andrés de Meneses had in possesion were located at the Pescadería Street. 2. Juan de Villena's home was "next to the marmol de bronce.” 3 The properties of Doña María de Monterrey y Castro and Doña Juana de Orduña were located at Mantas Street. 4. Luis Alfonso de Rojas y Mendoza's house was located at Aldabas Streets. 5. The house Don Cristóbal Gutiérrez Galán rented from La Merced Monastery was located at Espaderos Street, just in front the monastery.
} 
Don Juan Suarez Dionis, vecino of Callao and owner of three stores in that port-town.

The receptor of the Colegio had filed a suit before the Real Audiencia against Don

Alonso Dies Fernandez,and his wife, Doña Petronila Maria de Leon y Suárez, heiress of Juan Suárez Dionis, because they owed some interests of a principal of 1,510 pesos that burdened the above mentioned stores. The rent of 75 pesos, 4 reales of principal paid for a capellanía that the priests of the school served.

Nevertheless, the earthquake destroyed all three stores that supported the capellanía. For that reason, the receptor of the school, Eulogio del Salto y Arriaza, offered to condone the interests that Don Alonso and Doña Petronila owned up to September 11, 1687, if they accepted to cover the reconstruction of the three stores and to pay the interests posterior to that date. Del Salto underlined he offered that option “considering some reasons of equity, and also [the effects of] the earthquake."349 Three weeks after the catastrophic event, both parties signed a notarial contract that detailed the clauses of this agreement. ${ }^{350}$ With this legal but out-of-court resolution, both parts ended with the judicial process that placated them.

${ }^{349}$ AGN, PN Siglo XVII, 1059, f. 1221v.

${ }^{350}$ Ibid, f. 1222. 
Fighting against a powerful colonial institution was not easy, as the case of Meneses illustrated, yet such battles were not uncommon. Nor was his argument - to take into consideration the extraordinary damage produced by the quake. Doña Mencia de Cáceres y Ulloa, another censataria, requested a discount on the rent she paid for a house and two adjacent stores, which belonged to the Monastery of La Concepción. She explained that they were in ruins and the necessary repairs were very expensive. She explained that when she received those properties in censo, in 1659, she had to spend around 4,000 pesos repairing the damages they suffered by the earthquake of 1655 . Nonetheless, the Earthquake of 1687 had left the house and stores in such terrible condition that she was unable to rent the stores and live in the house. She argued that, although the ninth clause of the contract stated she could not request discount because of any misfortune or tremor, the clause should not rule in that occasion because the Earthquake of 1687 had produced a total ruin. ${ }^{351}$ Both Gonzalo de Meneses and Mencia de Ulloa demanded that the clauses obligating the censuatarios to refurbish the properties be made ineffective in critical occasions of total devastation such as the one they were experiencing.

${ }^{351}$ AAL, Series Cofradías, XXV: 37, 1688. 
Even though proposals as those of Meneses and Ulloa cited the critical conditions

of the city, opposing parties did not automatically accept them. Negotiation occurred in different ways in judicial processes involving reconstruction. People used legal spheres and adopted legal forms to legitimize reconstruction projects; and they recreated or adapted such legal forms as they did so. Meneses and Ulloa confronted powerful religious institutions that had personnel overseeing judicial and administrative matters. The monasteries kept attorneys, accountants, and similar professionals on retainer to manage and protect their properties. Individuals such as Meneses, himself a clerk at the Real Audiencia, probably had certain knowledge of laws or legal procedures and arguments. Yet other petitioners, such as Doña Mencia de Ulloa, were unfamiliar with the intricacies of the judicial apparatuses. Nonetheless, in both processes the plaintiffs based their requests on the presumed inapplicability of the contracts' clauses obligating them to rebuild the properties, claiming the extraordinary conditions made it impossible to fulfill them. Nor were tenants the only ones citing the extraordinary conditions in claims for their reconstruction projects. Similar claims reveal how the inhabitants of Lima advanced legal arguments that extraordinary situations could trump ordinary agreements. 
A similar reference, though focused on the capriciousness of nature in Lima, appeared in another reconstruction plan-- this one devised by the administrators Alonso Perez Campos and Pedro de Larreta who, as discussed above, presented a plan before the judge Mansilla a year after the quake. They explained that the earthquake had damaged most of the confraternity of the Limpia Concepción’s properties, which were burdened by censos, capellanías, and other pious works. They proposed that, as an “accidental event,” both owners and tenants together should cover the expenses of the repairs. The administrators even offered to grant a "legitimate reduction" of the annuities to the censuatarios in order to compensate them for the expenses they had to incur repairing the confraternity's properties. ${ }^{352}$ In all the three cases, the petitioners mentioned the extraordinary circumstances of the city required exceptional measures to reconstruct a great quantity of properties that needed expensive repairs that most proprietors or tenants were unable to afford. Even the receptor Del Salto claimed that his offer to tenants was motivated by the earthquake and reasons of equity. It seems most limeños were attempting to reach fair and reasonable settlements.

\footnotetext{
${ }^{352}$ AAL, Series Cofradías, IV: 21, f. 1 v.
} 
Even though the results of these judicial processes differed, petitioners used these and similar arguments to obtain a legitimate authorization from the ruling judge to implement their projects of reconstruction. But plaintiffs did not always obtain the recognition or authorization to the rebuilding plans they pursued. In the suit that Meneses filed against the monastery of the Concepción, this institution used conventional legal arguments to defend its interests and to reject its tenant's proposal. There is no evidence on file in the judicial process to know if Meneses finally abandoned the property, even though he was contractually obligated to repair the property that legally remained under his stewardship.

Certainly, many tenants simply abandoned the properties they held on censo. Almost four months after the earthquake hit Lima, the abbess of the Monastery of Santa Clara requested from the Vicario General of the Archbishopric of Lima license to sell "for lives" some ruined properties. ${ }^{353}$ In this instance, the term "for lives” (por vidas) refers to a lien held in emphateusis. The monastery would lease some properties for a determined period of time, which was counted in tenants and their heirs' lives. In her petition, she explained that the earthquake destroyed all the houses and other buildings that belonged to

\footnotetext{
${ }^{353}$ In this instance, the term 'for lives' (por vidas) refers to a censo enfitéutico. The monastery would lease some properties for a determined period of time, which was counted in tenants and their heirs' lives.
} 
the monastery. Because of these unexpected damages, the monastery did not have enough funds to cover the repairs of such properties. She asked for permission to lease "for lives" those properties that were in need of more repairs. Because there were people willing to contract censos on favorable terms, the abbess argued that these contracts would keep these properties producing rent, and transfer the responsibility to reconstruct them to the tenants. ${ }^{354}$

Unlike the authorities of the Monasterio de la Concepción, who refused to concede discounts on either principal or rents to their tenants, the Monasterio de Santa Clara accepted the renunciations of possession from some of its censatarios. Concepción’s administrators supported their position on contract's clauses that obligated tenants to rebuild the properties they occupied and forbid them to cancel the agreement. Nonetheless, institutions had the option to accept tenant's renunciation. For instance, the city council, as explained in chapter 2, accepted the request from the tenants of the alhóndiga (city warehouse) to cancel their possession. Similar to Santa Clara's abbess, city counselors understood it was practical to find tenants willing to afford the reconstruction of property in exchange of fair condition rather than force them to hold unproductive useless buildings.

${ }^{354}$ AAL, Serie Santa Clara, XIX, 6, f. 1 - 3. 
As property owners, female religious orders and its members, individually, became highly involved in reconstruction activities after the quake. Women living in convents and other spiritual institutions represented 20 percent of the whole female population in Lima. ${ }^{355}$ They were an important population of limeños who helped rebuild the city. In her petition before the ecclesiastical court, the abbess of Santa Clara, Doña Luisiana Mesia—head of the monastery and responsible for its possessions—was not negotiating with other opponent parties, but requesting a license to implement a rebuilding plan. Similar to the abbess, many other petitioners came before the ecclesiastical court requesting permission to execute their own reconstruction plans. The most frequent of these requests came from nuns whose cells had collapsed during the quake. Doña Beatriz de Torres Solano, one of the oldest velo negro (elite) nuns in the Monasterio de la Concepción, requested a license that may grant to her brother, chaplain at the same monastery, and other construction laborers access to come inside the cloister to repair her cell. ${ }^{356}$ Doña Maria Franco, another black-veiled (elite) nun from the same institution, also asked permission for her nephew, Licenciado Don Fernando de Aller y Franco, to come inside the monastery

\footnotetext{
${ }^{355}$ Van Deusen, Entre los sagrado y lo mundano, 203.

${ }^{356}$ AAL, Section Monasterio de la Pura y Limpia Concepción, XXV: 51, f. 1.
} 
with the purpose of recognizing the repairs her cell needed. ${ }^{357}$ The two petitioners claimed the earthquake had damaged their cells so badly that they had to sleep outdoors. In both cases, the abbess Doña Petronila de Jesús y Salazar certified that the earthquake had destroyed all the cells in the monastery. The sisters could not even enter them. Some nuns, such as Doña María and Doña Beatriz had male relatives willing to cover rebuilding expenses. Yet even these close relatives required a special license to enter the monastery. Since nuns also required permission from the ecclesiastical court to perform temporal activities, nuns left valuable testimonies of their reconstruction activities. Doña Aldonsa de Mora, black-veiled nun in the Monasterio de Santa Clara, solicited permission from the Provisor y Vicario General to sell (transfer) a censo of 250 pesos she had imposed on a house. She explained in her request that she received only 12 pesos 4 reales of interest every year. Since such amount was insufficient to support her, she wanted to "sell" the censo to have enough currency from the principal to repair another house ruined by the earthquake that she possessed on lien. ${ }^{358}$ Another black-veiled nun of Santa Clara, Doña Ana de Pereira, requested the license to use 2,000 out of 3,728 pesos

${ }^{357}$ AAL, Section Monasterio de la Pura y Limpia Concepción, XXV: 62, f. 1

${ }^{358}$ AAL, Section Santa Clara, XIX: 7, f. 1. 
that she inherited from her aunt and her father for repairing some properties. She explained that that amount was in power of the executor of the belongings of her uncle, Licenciado Martín Dominguez Zambrano. She planned to use such 2,000 pesos to repair two houses of her property that were damaged in the seismic event. She needed to rebuild those buildings in order to lease them. ${ }^{359}$ With these strategies, Doña Aldonsa and Doña Ana attempted to obtain the economic means to put in repair and make functional properties that they could lease to receive regular income.

In all the cases seen in this section, the petitioners brought their plans of reconstruction before court to get the judge's license or order to implement their projects. Some of the petitioners requested licenses to put forward their plans, specifically, when these did not affect third parties. Other plaintiffs brought their projects before the judge in order to reach a settlement with opponent parties. Even though some of the cases had a negative or inconclusive outcomes, they illustrate the quest for legal authorization or legitimization of a plan, or help in compelling the opposing parties to negotiate or consent to a final project of reconstruction. But the courtroom was not the only place limeños had to legitimize their rebuilding plans.

${ }^{359}$ AAL, Section Santa Clara XIX: 12, f. 1 - 2, 21 - 22. 


\section{Contracting Before Notaries}

The destruction of such a large part of the city represented a critical moment for many estate holders unable to afford the unexpected costs of reconstruction. Such large expenses motivated limeños to validate their rebuilding plans before implementing them. Instead of bringing their proposals of reconstruction to magistrates, proprietors negotiated rebuilding agreements with contractors and tenants. The Spanish legal system offered their subjects other official alternatives to legitimatize these agreements: the notarial contracts. The various parties involved in a negotiation signed a written agreement before a notary, who certified the veracity of the contract's content.

Certainly not all property owners were economically limited to afford

reconstruction activities. As seen in chapter 3, large property owners, such as some of the religious orders, had the economic means to reconstruct their properties. Nonetheless, even those individuals who had some capital to use in rebuilding works had to make special arrangements with contractors. Just a few weeks after the quake, Maestre de Campo Don Luis Alfonso de Rojas y Mendoza contracted with the carpenter Juan Eugenio and the Lieutenant Cristobal Perez to reconstruct his house. He would pay 200 pesos to Eugenio and Pérez, who agreed to complete the rebuilding works within six 
weeks. ${ }^{360}$ The contract specified that the said 200 pesos were for Eugenio and Perez’s labor because, in order to reduce expenses, Rojas would provide the materials of construction and directly hire the black peones (laborers) to assist with the demolition and rebuilding of the ceiling, and the removal of the debris. ${ }^{361}$ Even if Rojas had enough money to initiate the repairs on his home, he carefully arranged with the construction masters the responsibilities of each party in the contract, in order to save time and money in the reconstruction activities.

Even though some of Lima's estate-owners had the means to rebuild their damaged properties in such a short period, many had to bargain or negotiate their plans of reconstruction with tenants. Lease contracts offer illustrative information on strategies of cooperation and concession that limeños, both proprietors and tenants, developed with the purpose of rebuilding their city.

A couple of weeks after the earthquake, a property owner and a capellanía beneficiary signed a lease contract with a prospective tenant before a notary. According to this contract, Doña María Monterrey y Castro, widow of Sebastian Gutiérrez, executor

\footnotetext{
${ }^{360}$ AGN, siglo XVII, PN 1634, Mateo de Rivera, f. 115 - 115 v.

${ }^{361}$ Ibid.
} 
of his will, and guardian of their minor children, rented to Sebastian de San Miguel a house and an adjacent store, located on Mantas Street, for a period of six years. Mantas was one of the main commercial streets in Lima, located next to the city hall. It received this name from the various stores that initially sold blankets of the land or mantas. Large two-story residences hosted various ground-level stores, where proprietors had their own business or which they rented for extra income.

Because the quake extensively damaged Doña María’s property, she decided to rent it to someone willing to cover the repair expenses. The parties set the amount of the annual rent on 300 pesos. From this total, they agreed to discount the tenant's expenses for demolishing the second story and rebuilding the property as new, following the alarife or construction master's instructions. In case the cost of repairs exceeded the amount the tenant must pay, the Lic. Don Luis de Avalos, beneficiary of the capellanía on the house and store, would cover the additional expenses. ${ }^{362}$ They also agreed that the contract would start to run from the day the constructor master certified that the property was habitable. A year later, Doña María Monterrey, one of her children, and the heirs of San Miguel, appeared before the notary to insert an addendum to the contract. They

\footnotetext{
${ }^{362}$ AGN, siglo XVII, PN 202, Don Juan de Beltrán f. 602 v.
} 
declared the reconstruction of the house and adjacent store ended on April 1, 1688, date from which the lease started to run as indicated in the original contract. The cost of materials and salaries reached almost 2,000 pesos, which the proprietor accepted as payment of the lease. ${ }^{363}$ Thus, not only did the proprietor and tenant agree to share the expenses of the necessary repairs in the property; the chaplain, who also received profits from the property, also had to participate in sharing the costs.

In another contract, Doña Juana de Orduña, the former abbess of the monastery of Santísima Trinidad, with license of the current abbess, granted possession of a store located also at Mantas street to the Lieutenant Mateo de Arzave. The contract, which both parties signed before a notary, indicated that the store was in such bad condition that both parties agreed the tenant would pay for the repairs the store needed. In exchange, the nun ceded the possession of the store for six years, and discounted all tenant's expenses from the monthly rent. ${ }^{364}$ Similar to the previous case, the lease period would begin from the date all repairs of the stores were concluded.

\footnotetext{
${ }^{363}$ The tenant expended 1949 pesos $1 \frac{1}{2}$ real. Ibid, f. $601-604$, at the margin.

${ }^{364}$ AGN, siglo XVII, PN 1059, Diego Marquez de Guzman, f. 1225v-1226.
} 
As these two cases illustrate, some leaseholders agreed to pay the costs of repairing damaged properties in exchange for obtaining possession or usufruct for certain period of time. Real estate owners had to agree to reduced rent payments for their property, as in the case of Doña Juana de Orduña, or even lost such income altogether temporally when the tenant used the money to pay the properties' repairs, as it happened to Doña María de Monterrey. In both cases, the owners also agreed to consider the beginning of the contracts by the date the properties were in good condition. This clause could motivate tenants to delay repairs in the properties, yet its repetition in many other contracts seems to show it became a common concession by owners to motivate tenants into contracts.

Another frequent arrangement between owners and tenants was to share the costs of rebuilding. Almost a month after the quake, Fray Pedro Gudiño, as Prior of the Monasterio de la Merced, and the Lieutenant Don Cristóbal Gutiérrez Galán signed a lease contract before the notary Don Francisco Sanchez Becerra. Gudiño ceded possession to Gutiérrez for nine years of a one-story house with two adjacent stores for 450 pesos. In this case, Gudiño, as representative of the monastery, declared the earthquake left the property uninhabitable, so it required several repairs. He did not grant 
a delay in the beginning of the lease, as the other proprietors did in the previous cases; yet he did discount 150 pesos from the total amount of 450 pesos. The tenant would use those 150 pesos to pay for the repairs of the entire property. Nonetheless, the monastery offered to contribute all the necessary materials of constructions such as bricks, adobes, quicklime, and wood. ${ }^{365}$

These kinds of agreements, which show proprietors' and tenants' interest on reaching fair settlements, were not uncommon in the notarial records. In another contract, the proprietor, Dona Catalina Montero, also offered materials of construction to the leaseholders Lorenzo de Alvarado and Juan de Albornoz. She rented them some storages with a house located in the port of Callao for six years at the price of 1,100 pesos each year. She would receive only 300 pesos, and would provide wood to assist in the repairs. The tenants would use the remaining 800 pesos to rebuild the warehouses in the first year of the lease, and the house in the following years. ${ }^{366}$ In this case, the proprietor not only agreed to provide construction materials, but also ceded part of the rent income to be used for the rebuilding works.

\footnotetext{
365 AGN, siglo XVII, PN 1698, Don Francisco Sánchez Becerra, f. 1223-1224.

${ }^{366}$ AGN, siglo XVII, PN 1674, Juan Romero de Arnero, f. 79v - 80v.
} 
Even though these contracts represent just a portion of those preserved in the notarial records at the Archivo General del Perú, they illustrate both the strategies limeños adopted to rebuild private property and their efforts to legitimize their agreement to put the city back together after the earthquake. These documents also testify to limeños' interest in recording their agreements in written format. The practice of writing usually protected the parties involved, even though some agreements were not literally fulfilled. In other words, the documents provided the individuals legal protection more apparent than real. Even so, they valued the notarial record enough to regularly seek it. The notarial records were formal resolutions that the parties in the contracts reached after some sort of negotiation and bargaining.

These contracts were the result of limeños’ negotiation according to their own understanding of equity, their will of cooperation, and their needs to rebuild property. Unlike judges that mediated negotiations and settlements, notaries mainly recorded what contracting parts had already negotiated. Scribes and notaries could certainly clean-up the wording in the contracts, making it clear and intelligible according to notarial standards. But post-earthquake contracts contained specific details in the clauses that exclusively fit 
the needs of each case. ${ }^{367}$ Certainly these documents followed customary notarial formulas similar to other contractual documents, yet each contract provided particular strategies of reconstruction that were selected according to each case. The value of these notarial records is that the casuistic and flexible Spanish system allowed limeños to negotiate and implement “conveniente” agreements for the parties involved.

\section{Informal Valid Agreements}

The importance of written resolutions, obtained either in court or before a public notary, did not overshadow the value of informal oral contracts. These kinds of agreements are difficult to access because, by their very nature, they were unwritten or informally registered and thus were not well preserved. For that reason, references to such informal agreements usually are left out of courts and notaries’ records. But when we can catch sight of them, we learn that, despite their extralegal nature, these arrangements were valid, since they had the validity that the parties involved tacitly or symbolically conferred them. The use of these extra-official contracts shows people's desire to reach fair resolutions through application of casuistic jurisprudence and negotiation.

\footnotetext{
${ }^{367}$ Kathryn Burns, Into the Archive. Writing and Power in Colonial Peru (Durham: Duke University Press, 2010), 93.
} 
The analysis of a series of these unofficial contracts, which the steward of a religious corporation arranged, reveals the flexibility they afforded the people. In 1692, the Captain Don Agustín de Castro, steward of the confraternity of the Santísimo Sacramento, located at the Cathedral of Lima, presented the account of the six years of his administration before Don Juan de Mansilla, Judge of Testamento, Legados y Obras Pías. ${ }^{368}$ His detailed account of 125 pages with more than 500 entries provides revealing data about the impact of the earthquake on the confraternity's properties and how he managed to repair and maintain the rents of those most damaged.

The Santísimo Sacramento confraternity had around 30 real-estate properties among houses, stores, and small second-story rooms (altillos) spread throughout the city. It also collected the fees of provisional stalls or spots in a commercial alley where merchants sold diverse menial products such as clothes, fabric and other goods. Of these properties, the earthquake damaged seriously at least 11 , which required several repairs that the congregation could not afford directly. For that reason, Castro set informal

\footnotetext{
368 José Manuel Bermúdez, Anales de la Catedral de Lima, 1534 a 1824 (Lima: Imprenta del Estado, 1903), 118, 128. The confraternity of the Santísimo Sacramento appears in the records of the Cathedral since 1663. The edification of its chapel began in 1668.
} 
agreements with some of the tenants to jointly pay for the rebuilding of these

properties. ${ }^{369}$

Castro's first measure was to exonerate from payment those tenants who, because

of fear, abandoned the properties in good condition for a few days. He discounted Juan

Bautista Bentin the five days he abandoned the altillo he occupied. ${ }^{370}$ Castro also

discounted from rent some of the expenses the tenants made on the properties or

communal areas. For instance, Castro discounted tenant Juan de Mena 9 pesos of his

monthly payments for cleaning the ditch that ran next to the property. Castro also

exonerated Mena from the payment of 2 months and 19 days out of 24 months that he

lived in the property because he lost all his personal belongings with the earthquake. ${ }^{371}$

In another case, instead of using the limited funds of the confraternity to pay for

repairs, Castro informally rented damaged property to people who were willing to rebuild

it in exchange of free occupancy. He rented a store to the Captain Antonio de Herrera,

who took possession on November 28, 1687, one month after the quake. Since Herrera

\footnotetext{
369 Archivo Historico de la Beneficencia Publica de Lima (herafter AHBPL), COF-SS-10, $125 \mathrm{fs.}$

${ }^{370}$ AHBPL, COF-SS-10, entry 45.

${ }^{371}$ AHBPL, COF-SS-10, entry 47.
} 
expended 113 pesos in repairing the store, Castro established April 10, 1688, as the starting date of the lease agreement. In other words, Castro granted four and a half months of free occupancy to Herrera in exchange for repairing the store. ${ }^{372}$ This was a smart and extra-official strategy to prevent extraordinary costs to his congregation and transfer them to a tenant that had the capital to restore the property.

Like other bodies whose properties were greatly damaged, the confraternity's administrator had to look for available means to rebuild real estate. In June 17, 1687, Castro rented to Bartolomé de Arcos, silver master, a house for 240 pesos annually. Arcos paid 80 pesos for the four months (20 pesos each) he occupied the house until the earthquake hit. Because the house was so seriously deteriorated when Arcos returned to it, on March of next year 1688, Castro reduced Arcos' monthly payments from 20 to 8 pesos. This was a reduction of 60 percent of the original price. ${ }^{373}$ In this case, it is evident the earthquake caused such severe damage to the property that the administrator had to reduce the rent with the purpose of keeping the tenant, who would probably make

\footnotetext{
${ }^{372}$ AHBPL, COF-SS-10, entry 60.

${ }^{373}$ AHBPL, COF-SS-10, entry 104.
} 
improvements or repairs. Reducing the price of a lease payment was more effective than losing the total rent and having to cope with the repairs on one's own.

Castro's recording of his different tactics to reconstruct the property of the confraternity demonstrates that people commonly set unofficial agreements. These were practical in terms of costs of money and time. They also reflected official agreements because they specified the obligations of each part, and were valid and recognized by the parties involved. In the case of Castro's ledger, the annotations of all these simple settlements did pass before the ecclesiastical judge's eyes at the end of his term as steward. Nonetheless, they were legitimate long before the judge certified their validity. Even if the ledger and the arrangements it contained had never reached the ecclesiastical court, the agreements were deemed binding from the moment the tenants and the administrator established them, shook hands, and respected them.

\section{Conclusion}

Although colonial authorities took measures to initiate reconstruction, ordinary people had to partake in rebuilding activities of their city. They developed diverse reconstruction plans according to their own needs. Implementing these projects required the participation of various individuals, such as colonial authorities, property owners, 
tenants, and contractors, willing to negotiate and accept part of the economic burden of rebuilding. These reconstruction projects were validated through written contracts, notarized verbal contracts, and even informal verbal agreements. The Spanish legal system recognized all three kinds of agreements as legitimate and binding. The abundant cases referring to each type highlights the value legal negotiations had to colonial subjects and the extent to which subjects were familiar with early modern processes of law.

The main difference between official and extra-official contracts is the amount of money and property involved in each case. Parties fighting over a censo of 1,000 pesos typically had the means to pay court costs. They invested time and money in hopes of a sizeable gain. In contrast, the administrator of a small room, providing a monthly rent of 20 pesos, typically preferred to make an informal agreement with the tenant to avoid the cost of official validation. While weighty disputes moved some parties to negotiate or confirm agreements in official spheres, the desire to validate contracts was present at both levels.

Resolutions not only helped rebuild Lima’s physical surroundings, but also politically contributed to the refortification of the colonial state. Both the colonial ruling 
elite and the colonial subject participated in the process of reconstructing the city.

Colonial subjects engaged the Spanish legal system, both officially and informally. In

doing so, they used and reproduced the forms of the legal cultures according to their own necessities. Flexibility and compromise permitted the colonial subjects to design their projects of reconstruction in terms they considered fair and "conveniente" for the parties involved. Rather than negative characteristics, flexibility and "conveniencia” made the Spanish colonial state sturdy enough to resist the threat not only of natural disasters but also of the empire's political and economic challenges.

Certainly, flexibility and “conveniencia” made room for corrupt administrators and loose centralization. Royal officers and authorities were not all loyal administrators of the king's patrimony. Some of them set their own interests above those of the monarch. The Archbishop Liñán y Cisneros and the members of the ecclesiastical council, who received their appointments from the king, provide a clear example of authorities, in this case religious ones, primarily concerned with securing their material wellbeing. Indeed, the next chapter demonstrates that flexibility had its limits, and the king and his peninsular ministers asserted power of colonial administration, and set limits to self-interested behavior of colonial agents. 


\section{CHAPTER 5: SERVING THE KING: CONTROL AND}

\section{ADMINISTRATION OF THE ROYAL TREASURY OF LIMA IN THE}

\section{LATE SEVENTEENTH CENTURY.}

The destruction produced by the earthquake demanded costly repairs of most of buildings in the city. The Viceroy attempted to initiate rebuilding activities in the main public buildings without burdening the royal treasury, which for an extended period had maintained a negative balance. The Earthquake of 1687 increased the hardships of a government, which nevertheless was able to manage the critical post-disaster period. Even though the colonial administration in Lima was unable to perform its normal activities for several months after the disastrous event, the royal treasury of Lima drastically increased its remittances to Castile when the next armada departed from the port of Callao in $1690 .{ }^{374}$ This seemingly contradictory fact raises an important question: How, precisely, was Peru able to send such large sums to the metropolis in the middle of social, economical, and political strife?

\footnotetext{
${ }^{374}$ TePaske, John and Herbert S. Klein, The royal treasuries of the Spanish Empire in America, vol. 1 (Durham: Duke University Press, 1982): 337, 338. Comparing the coffers for periods 1681-1685 and 16851690, the amount sent in the 1690 armada was 225 percent higher than the one sent in 1685 . The amount collected by the royal treasury rose by 65 percent.
} 
Because the earthquake affected mainly Lima and its port, one explanation for the rise in remittances was that most of sub-treasuries at the viceroyalty's interior continued operating normally, compensating to some extent for the interruption of royal officers' ordinary activities in Lima. However, data shows that the condition of the royal treasury in the entire viceroyalty was precarious. It carried a large amount of debt accumulated as the result of decades' worth of loose book-keeping and mismanagement. Somehow, viceroys had continued to fulfill the obligation of sending money periodically to the peninsula. As the capital of the viceroyalty of Peru, Lima directed politics and commerce for all of Spanish South America. Similarly, Lima's caja real served as its main treasury. The treasury collected the capital's royal revenue and received the surplus of sub-treasuries from the viceroyalty's interior. ${ }^{375}$ In theory, Lima's royal administrators had to send the surplus to the metropolis; and, for a long time, royal officers fulfilled such obligation despite the depleted condition of the caja real.

When the quake hit in 1687, in a matter of a few hours, the city was in ruins and its administration halted. Despite the financial burden created by new expenditures related to the devastation, the Duke of Palata recognized that the King had other priorities that did

\footnotetext{
${ }^{375}$ Andrien, Crisis and decadencia, 43.
} 
not allow him to financially assist his loyal subjects in Lima. ${ }^{376}$ The Viceroy’s

achievement of realizing several of the rebuilding projects he envisioned is evident when examining the condition of the royal treasury. By the time the quake hit Lima, the condition of the caja real was bad, yet it had been worse. Actually, it was showing some signs of improvement because of a reformist phase that brought positive results that the natural disaster buried in historical memory.

This chapter explores the government's attempts to improve the administration of the viceroyalty's cajas reales, and the results of such reformist efforts, vis-à-vis the effects of the 1687 earthquake. It specifically looks at Lima's general inspection (visita general) ordered by the crown with the purpose of improving the condition of the royal treasury and tightening the control over its royal administrators. Even though the visita began in 1664, two decades before the natural disaster, its results became more evident during the administration of Duke of Palata, who actively promoted its activities and supported the visitor (visitador). Overall, a close look at the visita process provides a

\footnotetext{
${ }^{376}$ Navarra y Rocaful, “Memoria de Gobierno,” 367, “aunque en defensa y seguridad de la vida, honor y hacienda de tan Buenos vasallos emplearia Su Magestad todos sus tesoros con mucho gusto, no puedo ofrecerlo en los tiempos presentes, porque los aprietos de la Monarchia en las partes mas cercanas al Corazon [the peninsula], necesitan de todo el Socorro y asistencias de su Real hacienda, sin poderlas divertir a otra parte [Lima].”
} 
deeper understanding of how the colonial government dealt with bankruptcy and mismanagement during the late Hapsburg Spanish administration.

\section{The Economic and Political Black Legend of Spain}

Interpretations of Spanish decline trace their origins to political and economic decisions that monarchs made in the early decades of the seventeenth century, such as the excessive sale of juros (state bonds) and of public posts. The first of these practices, which started in the metropolis and expanded later to the colonies, generated an excessive public debt by the monarchy. In turn, that resulted in specie being passed to foreigners, a reduction of national capital, and privileged groups’ rising dependence on rentas.

According to this interpretation, Spain became a victim of its own debts, unable to implement a far-reaching program to alleviate and improve its condition. ${ }^{377}$ The "sale" of public offices had the similar effect of dispossessing the Crown of its capacity to control the administration of the empire. As most of the posts passed to colonies' native sons (Creoles) or peninsular residents in Indies, the royal government in the colonies became unable to rule for its own benefit because most functionaries profited from some

\footnotetext{
377 Alberto Marcos Martín, “¿Fue la fiscalidad regia un factor de crisis den la Castilla del siglo XVII?” in La crisis de la Monarquía de Felipe IV, coordinated by Geoffrey Parker (Barcelona: Editorial Crítica, 2006), 250 - 253. Geoffrey Parker, ‘Epilogue,’ in La crisis de la Monarquía de Felipe IV (Barcelona: Editorial Crítica 2006), 401, 402.
} 
illegitimate practices their posts permitted. ${ }^{378}$ Both practices had strong impact on the

politics of the empire during the rest of the seventeenth century, as they not only persisted

but also expanded. ${ }^{379}$

Nonetheless, the Spanish empire in the seventeenth century was not a monolithic administration condemned by the policies of previous rulers, waiting to be saved only by the coming of a new dynastic house and its new kind of government. Despite the various problems the Spanish empire had to deal with, Charles II’s administration had

378 Ángel Sanz Tapia, “Cargos politicos beneficiados en Hispanoamérica bajo Carlos II,” in Ciencia, Economía y Política en Hispanoamérica Colonial, coordinated by Antonio Gutiérrez Escudero (Sevilla: Escuela de Estudios Hispanoaméricanos 2000), 176 - 179.

${ }^{379}$ Mark A. Burkholder and D.S. Chandler, From Impotence to Authority. The Spanish Crown and the American Audiencies, 1687 - 1808 (Columbia: University of Missouri Press, 1977): 16. Margarita Suárez, Desafíos transatlánticos, 256, 257, also argues that the Spanish government suffered serious limitations. She views the royal administration in Spanish America as precarious and corrupt, and emphasized how each viceroy had to constantly renew the political pacts and arrangements with colonial subjects. The Spanish government's control over its colonial domain only weakened under Charles II. Sanz Tapia, “Cargos politicos beneficiados en Hispanoamérica bajo Carlos II,” 162; Corrupcion o necesidad?: la venta de cargos de gobierno americano bajo Carlos II (1674-1700) (Madrid: Consejo Superior de Investigaciones Científicas, 2009), 371-373, who argues that the Spanish administration continued to manage the concession of ruling positions. Even though he calculates that around 65 percent of the 1032 posts granted during the last quarter of the seventeenth century were beneficios or appointments given in exchange of monetary contributions or loans to the crown, these donations were considered services to the king. Even when the crown granted a large portion of royal posts to persons that offered economic donatives, 70 percent of these recipients also listed traditional service in their personal records. Moreover, the regime continued granting posts based only on traditional services, not pecuniary contributions. 
characteristics that show it was not as incompetent as scholars have traditionally argued.

Throughout the periods of war, natural disaster, and economic bankruptcy, the Hapsburg administration developed certain innovations and strategies that have inadvertently been erased in historiography. ${ }^{380}$ Analysis of the viceroyalty of Peru in the last decades of Hapsburg rule demonstrates that the government increased control of the colonial treasury, its royal officials, and the remittances of bullion to the peninsula. It was the Earthquake of 1687 that interrupted the reform and obscured its dividends.

\section{The General Visita to the Cajas Reales}

When Duke of Palata arrived in Peru, he attempted to implement various changes in the viceroyalty's administration. Some of his measures aimed to improve the fiscal administration. Yet, they were part of a larger reforming process that the Spanish crown

\footnotetext{
${ }^{380}$ Luis Ribot, El Arte de Gobernar, 14, 151, 152, 267 - 272, indicates that some administrative measures were the creation of the first Junta de Gobierno, and the replacement of the valido for the post of the prime minister. There was also an improvement on the diplomatic capacity of the Spanish officers to compensate the lack of military force, which was unable to resist the greater military power of Spain's enemies. Even the election of a Bourbon prince as the heir to the Spanish throne responded also to the political circumstances of the monarchy. Facing the menace of repartition among the European powers, the best option to preserve the monarchy was to choose a ruler the king of France would endorse.
} 
had initiated decades earlier with the purpose of regulating and supervising the personnel and administrative system in its colonial domains. ${ }^{381}$

The last decades of the seventeenth century (1664-1690) witnessed a long audit, through which metropolitan officials assessed the condition of Lima's caja real and the performance of its administrators. Because of the visita's duration, there were various visitadores, or auditors, that assumed the post consecutively. It is also possible to distinguish at least three phases of the visita, because there were some intervals in which inspections halted, such as when the visitor died or was recalled by the Crown (See Table 1).

The first of these stages witnessed the antagonism between the two visitadores, Juan de Cornejo and Francisco Antonio de Manzolo, who initiated their activities in 1664. Rather than fulfilling the expectations of the peninsular government, this initial phase of the visita fueled the factionalism within the political elite of the viceregal capital. ${ }^{382}$ Cornejo turned some royal officers into sympathizers, who benefited politically in exchange for loyalty and obstruction of Manzolos's activities. When news of the power

\footnotetext{
${ }^{381}$ Andrien, Crisis and decadencia, 241, 242.

${ }^{382}$ Ibid, 211-221.
} 
and authority he displayed in Lima reached the court, peninsular authorities recalled Cornejo in 1666. Manzolo continued inspecting the account of the royal treasury, without any formal accusation against the royal officers, until he left Lima in 1670. Conflicts between royal agents were not uncommon and even generated factions within the colonial administration. Just like the deep-seated ill-will between Manzolo and Cornejo, there was an evident antagonism between the Duke of Palata and the Archbishop Liñán y Cisneros, and between the latter and the Count of Castellar. These political, and sometimes personal, rivalries frequently obstructed the regular performance of the government, as some officers blocked the activities of their opponents.

The second phase of the visita initiated with the queen mother's appointment of Don Alvaro de Ybarra, the most senior oidor (judge) of the Real Audiencia, as visitor in 1673. The progress of the inspection was limited because one ally of former visitor Cornejo, Don Sebastián de Navarrete, administrator of Lima's caja real protested the bias of Ybarra’s procedures. ${ }^{383}$ In 1675 , the Council of Indies finally rejected Navarrete's appeal, and ordered Ybarra to resume the visita. Nonetheless, Ybarra died before the decree arrived in Lima. The next year, after receiving the news of visitor Ybarra's death, the king appointed

\footnotetext{
${ }^{383}$ Herzog, Upholding Justice, 33, describes recusación as a legal mechanism a party involved in a legal case or process could request the dismissal of the judge, court notary or court clerk because of impartiality.
} 
Don Agustín Mauricio de Villavicencio, the most senior oidor of the Real Audiencia, as new visitador by royal decree of June $1,1676 .^{384}$

\begin{tabular}{|c|c|c|}
\hline Years & Inspectors (visitadores) & Royal Treasury's Administrators \\
\hline $1664-1670$ & $\begin{array}{l}\text {-Francisco Antonio Manzolo. } \\
\text {-Juan de Cornejo (Recalled in } \\
\text { 1666). }\end{array}$ & $\begin{array}{l}\text {-Sebastian de Navarrete (Controller } \\
\text { imprisoned in 1681). } \\
\text {-Francisco de Colmenares (Treasurer) }\end{array}$ \\
\hline $1673-1680$ & $\begin{array}{l}\text {-Alvaro de Ybarra (Died in } \\
\text { 1675) } \\
\text {-Agustin Mauricio de } \\
\text { Villavicencio (Died in 1680) } \\
\text {-Juan de Saiceta y Chucho } \\
\text { (Secretary). }\end{array}$ & $\begin{array}{l}\text {-Cristobal de Llanos Jaraba (Business } \\
\text { manager). } \\
\text {-Francisco Antonio de los Santos } \\
\text { (Interim controller). }\end{array}$ \\
\hline $1680-1696$ & -Juan de Penalosa. & \\
\hline
\end{tabular}

Table 1: List of inspectors and administrators of the Caja Real (1664-1696)

\footnotetext{
${ }^{384}$ Translation of the Royal decree that commissioned the Audit. Lima, March 3,1683. Archivo General de Indias (hereafter AGI), Lima, 289, f. 1 - 7v. Ismael Jímenez, “Don Alvaro de Ybarra: el Criollo más poderoso de su tiempo (1621-1675),” América en la memoria : conmemoraciones y reencuentros / Begoña Cava Mesa, Coordinación y edición (Bilbao: Universidad de Deusto, Asociación Española de Americanistas, 2013), 324.
} 
Even though the visita progressed relatively slowly in this second phase, Villavicencio performed important tasks that would be useful for his successor in the inspection. His activities as visitor were in part obstructed by the unavailability of the records left by Ybarra. Visitor Villavicencio had to file a suit against the executor of Ybarra's will, who had sent Ybarra's documents concerning the visita, to Spain in the armada of 1675. It was not until March of 1679 that Villavicencio had access to such records. Nonetheless, he was disappointed to find out that most of Ybarra's papers contained information related to the recusal of Navarrete. ${ }^{385}$

Despite these initial setbacks, Villavicencio worked hard to fulfill the royal order to inspect Lima's treasury. Evidence shows that this royal official was determined to comply with royal instructions in every detail. Beginning in 1676, when he received his appointment, Villavicencio moved the investigations of Lima's treasury and its administrators' performance forward, until his death in 1679. Assisted by Don Juan de Sayceta y Cucho, Senior Accountant (Contador Mayor) of the Tribunal de Cuentas, Villavicencio's detailed investigation led to a long judicial process against the

\footnotetext{
${ }^{385}$ Letter of Villavicencio to the King. Lima, August 4, 1678. AGI, Contaduría, 1780B, f. 1 v.; Documents followed by the Visitador Don Agustin de Villavicencio against Don Lucas de Segura y Lara as executor of the Visitador Don Alvaro de Ybarra. Order of the Viceroy-archbishop about the papers of Ybarra. Lima, March 20, 1679, f. 77v.
} 
administrators of the caja real of Lima, the comptroller (contador y veedor) Sebastián de Navarrete, the business manager (factor), and the treasurer (tesorero), who were charged with suspicious practices and omissions. A few months after taking his new post, Villavicencio requested a sworn statement (relación jurada) from the officers of the caja real, detailing the debts owed to the treasury. ${ }^{386}$

Clear omissions in this account motivated secretary Sayceta and visitor Villavicencio to increase their scrutiny of the treasury's accounts. The officers of the caja real delayed presenting the documents that might corroborate their declaration for several months. The statement they submitted by the end of 1677 contained 755 entries that enumerated the uncollected amounts accumulated since the creation of the caja real of Lima in $1607 .{ }^{387}$ The total of debts owed to the caja real reached 232,967 pesos. ${ }^{388}$ Once Sayceta

${ }^{386}$ Letter of Villavicencio to the King. Lima, August 4, 1678. AGI, Contaduría, 1780B, f. 1.

${ }^{387}$ Sworn statement of the debts of the Treasury. Lima, November $6^{\text {th }} 1677$. AGI, Lima, 290, f. 168v $247 \mathrm{v}$.

388 Letter of Sayceta to Villavicencio. Lima, June 20, 1678. AGI, Lima, 290, f. 250. Unless otherwise specified, all quantities in this chapters are expressed in pesos de a 8 reales. Caja Real's royal administrators keep account records in both pesos de a 8 reales and pesos ensayados. In order to clarify the value of the debts by the royal treasury, I have converted pesos ensayados, tomines, and granos, to pesos de a 8 reales. Eight tomines were equivalent to one peso ensayado and twelve granos was equivalent to one tomin. Once pesos ensayados, tomines, and granos were expressed in pesos ensayados with decimals, by dividing pesos ensayados by one, tomines by eight, granos by 96 , and adding the previous three products, I 
reviewed this first account, he realized that there were 218 entries that lacked certain information such as the amount and the object of the debt. ${ }^{389}$ Therefore, he asked administrators to submit documents that could be used to verify each entry. Visitor Villavicencio compelled the administrators to provide the papers asked by Sayceta three times without success. ${ }^{390}$ Facing new obstruction of his activities, Villavicencio began to send notifications to the debtors compelling them to pay, and supervising the activities of royal administrators. He also recorded all new deposits to the royal treasury. In only five months, from December 10, 1677 until May 28, 1678 -- when the Viceroy Count of Castellar ordered Villavicencio to submit an account of the available money to send to the converted pesos ensayados to maravedíes, at the exchanged rate of 450 maravedíes per peso ensayado, and from maravedíes to pesos de a 8 reales, at the exchange rate of 272 maravedíes per peso de a 8 reales. For instance, after we convert pesos ensayados, tomines, and granos to pesos ensayados with decimals by following the calculation performed previously, we multiply the pesos ensayados with decimals figure by 450and divide by 272. I have also rounded up the figures as necessary. For instance, in this particular statement, they royal officers declared a debt of 224,584 pesos 2 reales de a 8 pesos, and 5,067 pesos 4 granos ensayados. I converted the 5,067 pesos 4 granos ensayados to pesos de a 8 reales. Using the above mentioned formula, I obtained 8,382.97 pesos de a 8 reales which was rounded to 8,383. Then, I added this amount of 8,383 pesos de a 8 reales to 224,584 pesos de a 8 reales and arrived at 232,967 pesos 2 reales.

${ }^{389}$ Ibid, 250, 250v.

${ }^{390}$ Inquire of Sayceta to Villavicencio. Lima, March 2, 1679. AGI, Lima, 290, f. 249v.; Letter of Villavicencio to the King. Lima, August 4, 1678. AGI, Contaduria 1780B, f. 1r. 
metropolis -- the visitador had collected 54,476 pesos, nearly a quarter of the treasury's outstanding debts. ${ }^{391}$

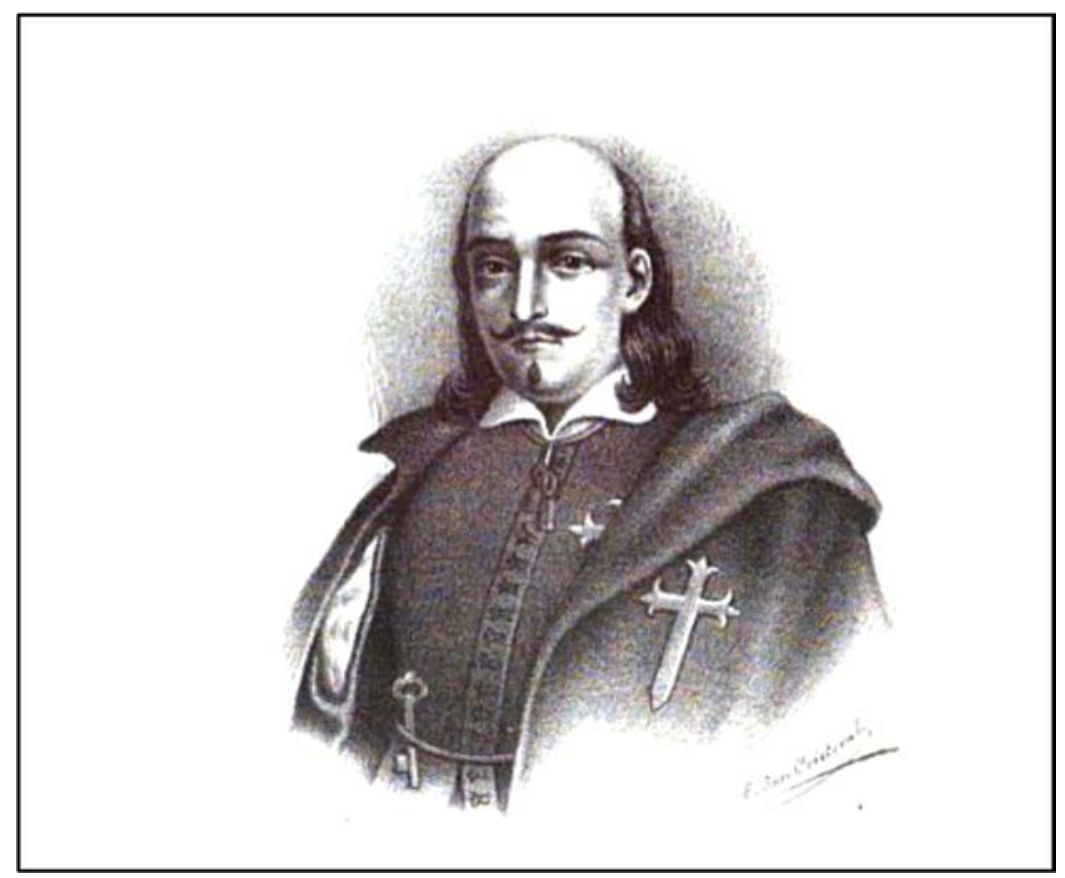

Image 15: The Count of Castellar ${ }^{392}$

A few months later, the appointment of a new viceroy and the death of Villavicencio brought another twist to the inspection of Lima's treasury. The King removed the Count of Castellar from his post of viceroy in July 7, 1678, and appointed the new archbishop of Lima, Don Melchor de Liñan y Cisneros, as interim-viceroy. The new representative of the

\footnotetext{
${ }^{391}$ Letter of Villavicencio to the King, Lima, August 4 1678. AGI, Contaduria, 1780B, f. 2; Letter of the royal officers sent with the galleons of 1686. Lima, Noviembre 12, 1683. AGI, Contaduria, 1780B, f. 2.

${ }^{392}$ Lavalle, Vivero, and San Cristóbal. Galería de Retratos de los Gobernadores y Virreyes del Perú, n.p.
} 
king spent the first months of his administration reviewing the various treasuries of the viceroyalty. He reported to the King that he found a debt of almost 4 million pesos. ${ }^{393}$ The caja real of Lima alone had a debt of 254,785 pesos 6 reales, accumulated as of December 19, 1679. ${ }^{394}$ Villavicencio had continued working until the first months of 1679 when his health decayed. His death in September of that year represented another halt to the inspection process.

Ultimately, this second phase of the visita revealed royal officials' fraud and shady book-keeping. But Villavicencio was unable to levy any harsh punishment on the royal officers because he lacked the authority to do so. His interrogations revealed that some officers, like Sebastián de Navarrete and Cristobal de Llanos Jaraba, lived ostentatiously, spending more than what their salaries could allow. ${ }^{395}$ The end of this phase also marked

\footnotetext{
393 The Archbishop-viceroy of Peru provides news to His Majesty. Lima, June 7, 1680. AGI, Lima, 288, f. $2 v$. The account listed only the debts of 16 cajas reales because the Archbishop-viceroy considered those of Loja and Guayaquil of little consideration, Huancavelica's and Huamanga's cajas reales did not report to Lima, and Quito's supported the Situado of Cartagena. The Archbishop-viceroy reported a debt of 3,806,623 pesos 7 reales. He stated that 2,167,439 pesos 1 real were debts from the Count of Castellar's administration, f. $4 \mathrm{v}-5$.

${ }^{394}$ Idem, f. 7. The Archbishop-viceroy reported a debt of 246,119 pesos 6 reales, and 5,238 pesos 1 tomin 3 granos ensayados

${ }^{395}$ Copies of the testimonies collected by Alvaro de Ybarra’s visita, Lima, 1677-1679. AGI, Lima, 289.
} 
the change in accountant Navarrete's position. It is uncertain what caused his fall from royal grace. It is possible that his activities of recusing Ybarra changed the king's perception of the accountant.

The third phase of the visita began a year after Villavicencio's death, in 1680, when the King ordered Don Juan de Peñalosa, judge of the Real Audiencia, to continue the investigation of Lima's treasure. Yet, in practice, it took more than appointing a new visitador to resume the inspection of the caja real of Lima. By the royal decree of October 23 1680, the king named Peñalosa auditor of the cajas reales and ordered him to resume the inspection along with Don Juan de Sayceta, who remained as secretary of the visita. ${ }^{396}$ Charles II also entrusted the imprisonment of the Don Sebastian de Navarrete and his banishment to New Spain to the new visitador. He specifically instructed Peñalosa to carefully inquire about the excesses and procedures of Navarrete and sequestrate his estate and personal belongings. The royal officer was imprisoned. Apart from this, there was no substantial progress in the visita during the administration of the Archbishop-viceroy. ${ }^{397}$

\footnotetext{
${ }^{396}$ Copy of the Royal Decree of October 23, 1680. Lima, March 3, 1683. AGI, Lima, 289, f. 11-12.

${ }^{397}$ Letter of Navarrete to the Viceroy, August 5, 1682. AGI, Lima, 288.
} 
After his arrival in late 1681, the recently installed Duke of La Palata reactivated the audit process which yielded positive effects. Without noticing any progress in the visita, the Viceroy commanded the Audiencia minister Peñalosa to begin his activities as visitador. ${ }^{398}$ Peñalosa requested an exemption to take his new post. This was a normal procedure since inspecting Lima's treasury earned visitors the animosity of most fellow royal officers. ${ }^{399}$ Even though Peñalosa provided reasons for his request, the Duke compelled him to formally take his new post and resume the visita.

Once the minister began his activities as visitador, his main goal was to send controller Sebastian de Navarrete, who along with two officers had been accused of fraud, to New Spain, place where he would wait for the sentence by the Tribunal de Cuentas, or the comptroller's court, as the royal decree of 1680 ordered. ${ }^{400}$ Once Navarrete embarked on a ship to Acapulco at the end of 1682, the new visitador was able to concentrate on the inspection of the treasury and the collection of debts.

\footnotetext{
${ }^{398}$ Auto of the Viceroy Duke of Palata to Juan de Peñalosa. Lima, February 18, 1683. AGI, Lima, 288.

${ }^{399}$ Letter of Peñalosa to the Viceroy Duque de la Palata. Lima, February 14, 1683. AGI, Lima, 288, N.2.

${ }^{400}$ Letter of Juan de Peñalosa oidor of Lima to His Majesty about the condition of the visita. Lima, November 4, 1683. AGI, Lima, 288, f. 2.
} 
According to the royal treasury administrators' sworn statement presented on March 31, 1683, at Peñalosa's request, the uncollected debts dating from the creation of the caja real in 1607 reached 255,472 pesos 7 reales. ${ }^{401}$ From 1683 until 1690, when the process against the royal treasury officers ended in a sentence, Peñalosa requested periodical reports from the administrators disclosing the progress on the collection of debts. He used the statement of 1683 to measure any progress in the collection activities. ${ }^{402}$

These reports demonstrate an increased effort by the royal officers to collect the delayed obligations to the Crown. According to the periodical reports presented by the royal officers, the debts in favor of the treasury decreased consistently. Using the report of 1683, Peñalosa sent a detailed account to the King, indicating that because of his efforts Lima's treasury had gathered 120,528 pesos 2 reales, representing almost half of the debt, in a period of eight months. ${ }^{403}$ Nonetheless, in a letter dated a few days later, the royal

\footnotetext{
${ }^{401}$ This was a third declaration presented by the royal officers stating that the debt owed to the caja real was of 234, 380 pesos 2 reales and 12,749 pesos 2 tomines 5 granos ensayados. They submitted the first statement at Villavicencio's request in 1679, and the second statement at Archbishop-viceroy's request in 1681. Letter of Villavicencio to the King. Lima, August 4, 1678. AGI, Contaduria 1780B.

402 These certifications are available in AGI, Lima, 290, and 291.

${ }^{403}$ Letter from Oidor Juan de Peñalosa of Lima to His Majesty about the condition of the visita. Lima, November 4, 1683. AGI, Lima, 288, f. 2. This letter stated that he had specifically collected 234, 380 pesos 2 reales, and 12,749 pesos 2 tomines 5 granos ensayados.
} 
administrators indicated that the large amount presented in the auditor's account contained quantities collected after the remittance of bullion in 1678 by the former Visitor Villavicencio. ${ }^{404}$ It is probable that Peñalosa intentionally failed to mention that the amount reported at the end of 1683 included amounts collected by his predecessor. Even though he used the material (testimonies, inventory, etc.) gathered by Villavicencio, Peñalosa never complimented the activities or procedures of the previous visitor.

The amounts reported in subsequent reports offer a more credible record of the royal officers’ collecting capacity. Efforts by administrators Francisco de Colmenares, Cristobal De Llanos, and Francisco Antonio de los Santos, who replaced to Navarrete as interimcomptroller, reduced progressively the debts shown on their declaration. ${ }^{405}$ In 1686 , Peñalosa ordered these royal officers to provide another sworn statement including debts incurred until April 8 of that year. ${ }^{406}$ This new account represented a considerable increase

\footnotetext{
${ }^{404}$ Letter of the royal officers sent with the galleons of 1686. Lima, November 12, 1683. AGI, Contaduria 1780B, f. $1 \mathrm{v}-2$.

${ }^{405}$ Memory and account of the debts owned to the Royal Treasury of Lima until March 31, 1683. Lima, March 31 ${ }^{\text {st }}$ 1683. AGI, Lima, 290, f. 1v.

${ }^{406}$ Notification of Peñalosa to the royal officers of the Real Hacienda, Lima, April 6, 1686. AGI, Lima,290.
} 
of debts the administrators were responsible for because it included the uncollected amounts of three additional years.

This new statement was split in three categories, one including debts since the creation of the treasury in 1607 until 1659, another that comprised debts from 1659 to 1679, and the last one that contained the most current debts (See Table 2). According to the new sworn statement of 1686, the first group of debts reached 12,315 pesos, the second 20,090 pesos 2 reales, and the third to 67,584 pesos 6 reales (See Table 2 ). ${ }^{407}$ The total debt of 255,472 pesos 7 reales, shown in the statement of 1683, had decreased to 99,999 pesos by 1686.

\begin{tabular}{|l|l|l|l|l|}
\hline $\begin{array}{l}\text { Statement of } \\
1686\end{array}$ & $\begin{array}{l}1607^{408}- \\
1659\end{array}$ & $1659-1679$ & $1679-1686$ & Total Debt \\
\hline
\end{tabular}

\footnotetext{
${ }^{407}$ Certification of the Officers of the Royal Treasury, Lima, August 4, 1686, AGI, Lima,290. The exact amount provided were 18,843 pesos 1 real and 753 pesoss 6 tomines 5 granos ensayados for the second period, and 65,606 pesos 3 reales de a 8 and 1,195 pesos 6 tomines 6 granos ensayados for the third period. ${ }^{408}$ Andrien, Crisis and decadencia, 114, states that the administration of the royal treasury was responsibility of the Real Audiencia until 1607, when the government created the Tribunal de Cuentas to supervise and control the viceroyalty's cajas reales.
} 


\begin{tabular}{|l|l|l|l|l|}
\hline Debt & 12,315 pesos & $\begin{array}{l}20,090 \text { pesos } 2 \\
\text { reales }\end{array}$ & 67,584 pesos 6 reales & $\begin{array}{l}99,990 \\
\text { pesos }\end{array}$ \\
\hline
\end{tabular}

Table 2: Debt of the Caja Real de Lima by 1686

Despite adding previously uncollected funds to their accounts, the royal officers

continued collecting debts and maintaining their accounts up-to-date. The report presented

ten days before the Earthquake of 1687 shows the debts to the royal treasury had

diminished, in all the three categories, within a period of 18 months. ${ }^{409}$ Even though the earthquake obstructed the work of the royal officials, it would only do so for a surprisingly short period of time. The report of 1690 shows they were unable to collect any quantity until September of 1688, almost a whole year after the natural disaster. ${ }^{410}$

Nonetheless, peninsular authorities kept pressuring on the administrators of Lima's caja real. In a royal decree, dated February 5, 1688, they expanded again the obligations of the royal officers, ordering the judges of the Tribunal de Cuentas to consider all obligations that were six months old as debts. ${ }^{411}$ As a result, colonial officials arduously aimed to collect debts before the six-month period. In 1690, the Tribunal sentenced the officers of

\footnotetext{
${ }^{409}$ Letter of Peñalosa to the King, Lima, October 15, 1687, AGI, Lima 288.

${ }^{410}$ Certification of the Officers of the Royal Treasury, Lima, June 20, 1690, AGI, Lima,290.

${ }^{411}$ Translation of the royal decree of February $5^{\text {th }}$ 1688. Lima, September 12, 1688. AGI, Lima, 291.
} 
Lima's caja real responsible for a debt of 16,245 pesos. ${ }^{412}$ This amount was considerably smaller than the debt of 255,472 pesos 7 reales the caja real had in 1683 (See Table 3). ${ }^{413}$

\begin{tabular}{|l|l|}
\hline Year & Debt \\
\hline 1683 & 255,472 pesos 7 reales \\
\hline 1686 & 99,990 pesos \\
\hline 1690 & 16,245 pesos \\
\hline
\end{tabular}

Table 3: Decline of the debt in the Caja Real de Lima from 1683 - 1690

Contrasting the amount of the 1683 and 1690 reports, it is evident that the inspection

of Lima's treasury generated, although to different extents, certain pressure on colonial administrators. They cleaned up their books and began collecting the extensive debts the treasury had incurred over decades. If they had previously committed fraud on purpose, the increased scrutiny surely stopped or reduced such behavior. By 1690, the royal fleet departed from Callao with a shipment of bullion that was three times bigger than the previous one.

\section{The Duke's Fiscal Reforms}

\footnotetext{
${ }^{412}$ Sentence on an appeal that the fiscal followed in the Tribunal de Cuentas against the royal officers of this city. Lima, June 10, 1690. AGI, Lima, 291, f. 553 r. The exact quantities were 15,693 pesos 5 reales and 333 pesos 2 tomines 6 granos ensayados.

${ }^{413}$ Letter of Villavicencio to the King. Lima, August 4, 1678. AGI, Contaduria 1780B.
} 
When promoting the visita's activities, Duke of Palata was mainly following instructions carefully detailed in various royal decrees signed by the monarch. Yet, he did not limit himself to merely implementing orders, but also designed and implemented some ideas of his own. His fiscal measures targeted to reform the inefficiency of the Tribunal de Cuentas by reviewing the viceroyalty's cajas reales and end the chronic scarcity of currency in the capital.

The Duke was concerned about maintaining an updated account record of the various cajas reales in the viceroyalty. The task was difficult for the royal officers working at the Tribunal de Cuentas, who supervised the activities of all the cajas reales. The accumulation of the unrecorded debts obstructed collection activities, which in turn increased the amounts due. ${ }^{414}$ The Viceroy appointed two auxiliary auditors (ordenadores) to support the Tribunal de Cuentas' senior accountants to organize the delinquent accounts. The Viceroy also decided that these new officers' salaries would derived from future debts collected in order to avoid burdening the royal treasury with more remunerations. ${ }^{415}$

\footnotetext{
${ }^{414}$ Copy of the Inquire to the Tribunal de Cuentas made by the Duke of the Palata. Lima, October 26, 1682. AGI, Lima, 288, f. 5v.

${ }^{415}$ Copy of the paper where the viceroy indicates the best manner of collecting of the royal treasury. Lima, December 8, 1682. AGI, Lima, 288, f. 2v.
} 
Additionally, he reorganized the duties of all five senior accountants and eight Tribunal de Cuentas' ordenadores by assigning specific provincial treasuries to each accountant and his assistants. ${ }^{416}$

In this manner, the Duke promoted order within the Tribunal de Cuentas, making each senior accountant responsible for inspecting specific cajas reales. Before this reform, accountants indiscriminately selected the accounts they wanted to review, alternating between various cajas reales and without following any chronological order. As a result of this practice, none of the cajas reales at the interior regions of the viceroyalty had its accounts up-to-date.

The Duke also promoted and realized the creation of a Royal Mint in Lima with the purpose of solving the continuous lack of coinage in the capital. Beginning in 1650, royal officers usually received their remunerations in bars of silver because pesos of 8 reales were scarce. ${ }^{417}$ In order to pay officers' salaries, fixed at pesos of 8 reales, royal treasury

\footnotetext{
${ }^{416}$ Distribution of the Cajas Reales by the Duke of the Palata. Lima, December 17, 1682. AGI, Lima, 288, f. $1 \mathrm{v}$.

417 Juvenal Luque, Funcionarios y remuneraciones. Salarios de la Caja Real de Lima en los siglos XVII y XVIII (Lima: Banco Central de Reserva del Perú, Instituto de Estudios Peruanos, 2011), 172-175, states that in the period from 1650 to 1675, payments in silver bars represented 91\% of the total. Between 1675 and 1684 , this percentage fell to $60 \%$.
} 
administrators had introduced the flawed practice of exchanging a silver bar at the rate of 142 pesos of 9 reales, when the value of each bar was actually higher, at 147 pesos of 9 reales. ${ }^{418}$

Visitor Villavicencio had previously noticed this practice, and realized its negative effects on the royal treasury. He notified the King that this procedure represented a loss of 5 pesos in each silver bar, and recommended a fine of 500 pesos to each senior officer of the caja real who made the exchange. ${ }^{419}$ The officers attempted to defend this practice by arguing the value of the silver bars constantly fluctuated on the market. They argued a silver bar only reached its nominal value of 147 pesos in the months preceding the departure of a royal fleet, yet it remained mainly between 135 and 140 pesos. They argued that the former Viceroy Count of Castellar had endorsed the customary rate of 142 pesos, after he verified the lesser value of the bars in the market.

Despite the attempt to defend the exchange practices, the royal officers had to pay the fine for contravening the legal value and exchanging of the silver bars at unfavorable

\footnotetext{
${ }^{418} \mathrm{Ibid}, 226$, describes the peso of 9 reales as a salary currency because it was mainly used to convert ensayados to pesos with the purpose of paying salaries.

${ }^{419}$ Letter of Villavicencio to the King, Lima, August 18, 1678, AGI, Contaduria,1780B.
} 
rates for the royal treasury. ${ }^{420}$ The production of coinage at Lima's Mint House progressively eliminated the payments of salaries in pesos ensayados, whose official value was fixed at 143 pesos of 9 reales, in $1685 .{ }^{421}$ When the Casa de la Moneda began to operate in 1683, the royal treasury entered a new stage where the peso of 8 reales became the standard coinage used to pay royal officers' salaries. ${ }^{422}$ The new institution also provided the much-needed currency for the diverse fiscal, commercial, and private transactions in the capital.

\section{The Danger of Living on the King's Peso}

A careful review of the Comptroller Sebastián de Navarrete's case reveals how the revival of Hapsburg governance impacted mid-level colonial administrators in Indies. He was a creole from Lima who forged a respectable career in royal service, yet his fate changed according to royal will. As the comptroller and his defenders tried to demonstrate his loyalty to the crown, they left behind material that provides a window to early modern notions of justice, law and custom, and colonial subjects' appreciation for written

\footnotetext{
${ }^{420}$ Letter of the royal administrators to the King, Lima, August 15, 1978. AGI, Contaduria, 1780B.

${ }^{421}$ Luque, Funcionarios y remuneraciones, 178.

${ }^{422}$ Ibid, 179.
} 
documents. Ultimately, Navarrete's career and life illustrates that flexibility and emphasis on "conveniencia" in the Spanish system had its limits. Royal officers could not hide behind claims of customary law and decentralized practices to justify personal gain. His prosecution and final outcome of his trial demonstrates that metropolitan authorities did not interpret flexibility as corruption.

Navarrete's father planned his young son's career well before he was able to take a position in the royal administration. He bought him a post in the royal treasury when the future comptroller was only 15 years old. ${ }^{423}$ He purchased this office in futura, which meant Navarrete would occupy one of the senior posts that might become available in Lima's caja real. Nonetheless, this meant that Navarrete would have to wait at least until he was 25 years old to enter in royal service.

Navarrete's opportunity came in 1651 when he replaced royal officer Bartolome de Astete, who was suspended from his office for a few years. Navarrete served as futurario comptroller until 1654. There were rumors that Don Sebastian was behind the suspension of Astete and another royal administrator, because he was the main beneficiary from such

\footnotetext{
${ }^{423}$ Kenneth Andrien, "The Sale of Fiscal Offices and the Decline of Royal Authority in the Viceroyalty of Peru, 1633 - 1700,” Hispanic American Historical Review 62, 1 (1982), 63.
} 
punishment. ${ }^{424}$ Navarrete received other appointment in the royal administration until he obtained full possession of the post of comptroller in Lima's royal treasury in $1663{ }^{425}$ Nonetheless, his ascending career hid a convulsive personal life. There were rumors that he had an affair with the wife of a Basque merchant. In an attempt to kill his opponent one night, Navarrete attacked him with the assistance of one of his slaves. Instead, he murdered a cleric, Fray Juan de Carbonero, by mistake. ${ }^{426}$ There seemed to be no long-lasting repercussions for this criminal act. In 1662, he was elected alcalde ordinario of the city, even though the Holy Office of the Inquisition excommunicated him because of his immoral acts in an attempt to obstruct his admission to the post. Navarrete’s political power was evidenced by his ability to overcome the greatest condemnation that the Church could inflict on a person with the payment of a fee. He had to pay a fine of 1,000 pesos before assuming the post of alcalde ordinario. ${ }^{427}$

\footnotetext{
${ }^{424}$ Andrien, Crisis and decadencia, 216.

${ }^{425}$ Certification by notary Jimenez Navarrete of a document made at Lima, in December 2, 1982. Mexico, August 12, 1683. AGI, Lima,288.

${ }^{426}$ Instruction to those in charge of the visita of the Cajas Reales and Caja of Lima, Madrid, Septembre 30,1680. AGI, Lima,288; Andrien, Crisis and decadencia, 236.

${ }^{427}$ Andrien, Crisis and decadencia, 216.
} 
Despite his tumultuous personal life, Navarrete's career continued ascending. He established strong connections with important families and other royal officers in the city. He married the daughter of Bartolome de Salazar, minister of the Real Audiencia, and became an open ally of visitador Cornejo. ${ }^{428}$ After his affair with the Basque merchant's wife, the Viceroy Count of Santisteban banished Navarrete to the coastal town of Pisco, where he remained for a few months. Yet, after the death of the Viceroy in 1664, Visitador Cornejo took control of the Real Audiencia, recalled Don Sebastian from exile, and appointed him as supervisor of the royal fleet and galleys. ${ }^{429}$

Even after Navarrete's protector, Visitor Cornejo, left the city in 1666, he did not lose his social standing. He actually improved his status by getting a promotion. By then, he had formally assumed the post of comptroller, and was a knight of the order of Calatrava. ${ }^{430}$ When Don Alvaro de Ybarra, minister of the Real Audiencia, resumed the activities of the

\footnotetext{
${ }^{428}$ Testimony of Sebastian de Arteaga, accountant of the Tribunal de Cuentas. Lima, June 28, 1677. AGI, Lima, 289.

${ }^{429}$ Account of Sebastian de Navarrete’s services. AGI, Lima,288.

${ }^{430}$ Testimony of Andres de Alseda Caro, clerk at the Tribunal del Consulado. Lima, July $19^{\text {th }}$, 1677. AGI, Lima, 289.
} 
visita in 1673, Don Sebastián resisted the activities of the new visitor, who was enemy of his former protector Cornejo.

In an attempt to stop Ybarra’s investigation of Francisco de Colmenares, a colleague in the administration of the caja real and a relative, Navarrete resorted to a legal resource known as recusación, or recusal. ${ }^{431}$ This mechanism allowed a plaintiff to put into question the capacity of an authority to properly perform his duties, without biases. Navarrete's legal move had the effect of delaying the inspection of the royal treasury, yet in the end the Council of Indies rejected his demand against Ybarra, and corroborated the authority of the visitador. Even though Ybarra, who died in 1675, was unable to receive the news of the Council of Indies' decision, his successor, Don Agustin de Villavicencio, initiated interrogation about the activities of the royal administration's officers. ${ }^{432}$ He questioned various witnesses about the royal officer's performance of duties, suspicious activities, and public life.

\footnotetext{
431 Jímenez, “Don Alvaro de Ybarra,” 317.

${ }^{432}$ Copies of the testimonies collected by Alvaro de Ybarra’s visita, Lima, 1677-1679. AGI, Lima, 289. There were 62 witnesses that answered the 80 questions that Ybarra designed.
} 
During Villavicencio’s investigation, witnesses’ most salient observation against the administrators of the royal treasury was their excessive living expenses. Contemporaries agreed that the officers were living with the decency that their post demanded. Yet they identified Sebastian de Navarrete and Cristobal de Llanos as the royal administrators that had the most ostentatious expenses. In contrast to Francisco de Colmenares, the third senior administrator of the caja real, who had a more frugal life, Navarrete and Llanos participated in ostentatious events reserved for elite gentlemen, dressed in livery and surrounded by a retinue. $^{433}$

When Villavicencio asked witnesses if they knew how Navarrete and Llanos could afford lifestyles that exceeded their income as royal officers, witnesses simply answered they believed both administrators had the wealth to live in such luxury. ${ }^{434}$ Only one witness, Don Diego de Segura y Lara declared, when interrogated about the expenses of

\footnotetext{
433 Testimony of Don Diego de Segura y Lara, Lawyer of the Real Audiencia. Lima, March 9, 1677; Testimony of Andres de Alseda Caro, clerk at the Tribunal del Consulado. Lima, July 19, 1677. AGI, Lima, 289.

${ }^{434}$ Testimony of Captain Pedro Luque Cosar, consul of the Tribunal del Consulado, Lima, July 8, 1677; Testimony of Sebastian de Arteaga, accountant of the Tribunal de Cuentas. Lima, June 28, 1677. AGI, Lima,289. These witnesses indicated Navarrete had received a dowry of 30000 pesos and a ranch when he married his wife, and a large inheritance of his aunt.
} 
the two officers, that visitor Ybarra told him several times that the royal treasury had been defrauded. ${ }^{435}$

It is unclear whether Villavicencio continued this investigation or sent a report of the interrogations to the King, yet news of Navarrete's overindulgences circulated through the court in Madrid. By 1679, the members of the Council of Indies knew about Navarrete's constant excesses and obstructions of the visita. Navarrete's denouncers claimed the comptroller spent wantonly, spoke with arrogance, and made threats to peers. ${ }^{436}$ Because news about Navarrete had circulate, when Charles II appointed oidor Juan de Peñalosa as visitor of the cajas reales, he ordered the imprisonment of Navarrete, the confiscation of his belongings, and his exile to New Spain. ${ }^{437}$ Even if they had not received an official denunciation against Navarrete, peninsular authorities ordered the visitor to investigate Navarrete’s excesses.

\footnotetext{
435 Testimony of Don Diego de Segura y Lara, Lawyer of the Real Audiencia. Lima, March 9, 1679 . AGI, Lima,289.

${ }^{436}$ Instruction to those in charge of the visita of the Cajas Reales and Caja of Lima, Madrid, September 30, 1689. AGI, Lima,288.

${ }^{437}$ Copy of the Royal Decree of October 23rd , 1680. Lima, March 3, 1683. AGI, Lima, 289.
} 
The Archbishop-viceroy and the Real Audiencia rapidly implemented the first two orders of the decree. During the night of June 7, 1681, the Alcalde del Crimen, the Alguacil de Corte, and 30 soldiers arrived at Navarrete's home to detain him and confiscate his goods. The alcalde took the comptroller to the court jail, where Navarrete remained for 2 months until he commuted jail for house arrest. ${ }^{438}$ Like many elite prisoners, Navarrete spent the following months enjoying certain freedom to move around the city, under a soldier's guard. ${ }^{439}$ When the new viceroy of Peru, the Duke of Palata, arrived at the end of that year, he was surprised to find out that Navarrete was still in Lima, contravening royal orders.

The new viceroy was determined to fulfill all the instructions of the royal decree, including the banishment of Navarrete. In 1682, the Duke attempted to send Navarrete to New Spain on a ship that would sail to Realejo. The officer tried to convince the Viceroy to concede him permission to remain in Lima, where he would be capable of preparing and conducting his own defense. In a final attempt to delay his departure, Navarrete indicated that Realejo was very distant from Acapulco, which was his official final destination. He

${ }^{438}$ Letter of Navarrete to the Duke of Palata, Lima, August 1682. AGI, Lima,288.

${ }^{439}$ Decree of the Virrey of New Spain, Marques de la Laguna, Mexico City, June 16, 1683. AGI, Lima,289. 
explained that he lacked the economic means to afford the trip by land from one port to another, because his salary was sequestrated. ${ }^{440}$ Finally, the Viceroy found the opportunity to send Navarrete in the ships that were set to sail to Acapulco carrying 3000 quintals of quicksilver. ${ }^{441}$

Soon after Navarrete arrived to Acapulco in early 1683, he claimed that the local weather took a toll on his health. He requested permission from the viceroy of New Spain, the Marques of Laguna, to travel to Mexico City. The Marquis accepted Navarrete's request with the condition that he would travel guarded by four soldiers paid from the prisoner's own belongings. ${ }^{442}$ Don Sebastian had to sell a slave and his clothes to cover the expenses of his move to New Spain's capital. ${ }^{443}$ The once powerful officer arrived in Mexico City on the night of August 5, 1683. He made his entrance to this city not with a retinue, as he was accustomed in Lima, but with the soldiers in charge of his custody. He

\footnotetext{
${ }^{440}$ Letter of Navarrete to the Duke of Palata, Lima, August 1682. AGI, Lima,288.

${ }^{441}$ Letter of Navarrete to the Duke of Palata, Lima, November 1682. AGI, Lima,288.

${ }^{442}$ Decree of the Virrey of New Spain, Marques de la Laguna, Mexico City, June 16, 1683. AGi, Lima,289.

${ }^{443}$ Letter of Navarrete to the King, August 10, 1683. AGI, Lima, 289.
} 
immediately was put in the city hall jail, where he would spend the remaining months of his life. ${ }^{444}$

Determined to reverse his situation, Navarrete prepared a detailed record of his services and attached it to a letter sent to the King, requesting permission to either return to Lima, where he could better defend himself, or appear before a Madrid court to demonstrate his innocence in person before the monarch. In the letter, he indicated that his unfair exile to New Spain was promoted by the animosity of his enemies who hated him for his loyal service to the crown. He argued that his loyalty to the crown was evidenced by the result of his activities as administrators, which increased the royal treasury of Peru by 3 millions pesos. ${ }^{445}$ The King did not agree with his strongly documented request. He simply ordered royal officials in Lima to move forward with the investigation of Navarrete's case. A second attempt by Navarrete to persuade the king was also

\footnotetext{
${ }^{444}$ Certification of the notary Juan Jimenez Navarrete, Mexico, August 12, 1683. AGI, Lima,288.

${ }^{445}$ Letter of Navarrete to the King, August $10^{\text {th }} 1683$. AHI, Lima, 288. He gathered several transcripts that certified the time he served as futurario and proprietor of the comptroller post, the confiscation he effectuated of various unregistered goods and silver in the port of Callao, his supervision of the armada of 1660, his administration of the stamped paper, and other services he performed for the Crown.
} 
unsuccessful. ${ }^{446}$ Finally, Navarrete died a few months later, on August 24, 1684, in a city hall cell in Mexico City. ${ }^{447}$

Navarrete's unsuccessful attempts to leave New Spain demonstrate that the crown had set certain limits on the behaviors of their royal officers' behavior. The King and the Council of Indies were unwilling to hear the claims by the royal officer. In other words, the number of charges against Navarrete had exceeded the parameters of his flexible authority as a loyal administrator. For that reason, they entrusted the visitor and the viceroy to perform a careful and detailed investigation to uncover Navarrete's faults. At the end, the comptroller had fallen out favor with the King.

\section{The Fighting Wife}

After Navarrete departed from Peru, his second wife, Doña Constanza de Loaisa y Mogrovejo, niece of late Archbishop Jeronimo de Mogrovejo, became his main advocate and legal representative. As soon as he received notification of his trip to Acapulco, Navarrete granted legal power to her to represent him in the visita process. ${ }^{448}$ She left

\footnotetext{
${ }^{446}$ Letter of Navarrete to the King, Mexico City, April 15 ${ }^{\text {th }}, 1684$. AGI, Lima, 288

${ }^{447}$ Testimony of notary Juan Jímenez Navarrete, August 25 ${ }^{\text {th }}$, 1684. AGI, Lima, 288.

${ }^{448}$ Request of Doña Constanza to the Visita’s judge demanding her husband's salaries. Lima, May 4, 1683. AGI, Lima,288. It includes a copy of the power Navarrete granted to her before departing to New Spain.
} 
abundant legal material from the multiple request, letters, and appeals she presented before the visitor. These documents offer elaborate arguments that unveil the early modern political elite's notions of justice and loyalty.

After the imprisonment of Naverrete in June of 1681, he continued to receive a customary payment of 2 pesos for each receipt (certificación) issued to any individual that made a deposit in the treasury. In 1683, the new assistant comptroller, Francisco Antonio de Los Santos, claimed the rights to collect the fee. ${ }^{449}$ However, Navarrete's wife argued that her husband was still the proprietor of the post because a condemnatory sentence had not been issued against him. ${ }^{450}$ Nonetheless, visitador Peñalosa ruled to suspend the collection of the fee because he considered that the royal officers' salaries covered their administrative activities and the fee "was an abuse introduced in common damage" of particulars. ${ }^{451}$ Both parties agreed that practice confirmed the comptroller's right to collect the fee. What was at issue was which of the two comptrollers should receive it. The visitor

\footnotetext{
${ }^{449}$ Letter of Francisco Antonio de Los Santos, Lima, January 3, 1683. AGI, Lima,288. The comptroller and the clerk that prepared the receipt shared the proceeds of the two pesos fee in equal proportions.

${ }^{450}$ Letter of Doña Constanza de Loayza y Mogrovejo, responding to Los Santos’ request, S/f. AGI, Lima,288.

${ }^{451}$ Decree of Juan de Peñalosa, Lima, July 28, 1683. AGI, Lima,288.
} 
decided to overrule the customary fee on grounds that it was not a prerogative of the post and it overburdened individuals with an extraordinary charge. ${ }^{452}$ In other words, the visitador decided to end a practice that was not legally contemplated in the office's privileges and was "inconveniente" to the large number of individuals that requested receipts for payments to the royal treasury.

When the news of Navarrete's death reached Lima, his wife was in midst of another legal battle to lift the embargo of her husband's salary and her dowry, which she claimed amounted to 30,000 pesos. Even though the royal decree that ordered the detention of Navarrete also commanded the embargo of his salary, the royal treasury's officers had paid a salary to their old peer until he sailed to New Spain at the end of 1682. When Visitor Peñalosa discovered this loophole for paying the royal administrator, he moved to seize Navarrete's salary, but the administrators had already disbursed it to him for the eighteenth month after his imprisonment. ${ }^{453}$ This irregularity also demonstrated that Navarrete was overstating his poverty when he requested permission from the King to return to Lima or appear before a Madrid court.

\footnotetext{
${ }^{452}$ Letter of Juan de Peñalosa to the Viceroy, Lima, November 4, 1683. AGI, Lima,288.

453 Testimony of notary Gabriel Perez del Castillo, Lima, March 5, 1683. AGI, Lima, 288.
} 
The most disturbing fact is that Doña Constanza, knowing about the salary disbursement, continued demanding Navarrete's remuneration from the day of his detention in June 1681 until the day of his death in 1684. She supported her demand on three clear points. First, she stated that, even though the royal decree ordered her husband's detention and instructed the confiscation of his salaries, it was Navarrete’s “divine, natural, and positive right” to make his defense, and that the king had provided that in such circumstances his royal orders "were obeyed, but not executed." 454 Second, she claimed that the accusations against Don Sebastian were defamations manufactured by the enemies he gained through his loyal services to the king. Third, he had the right to receive his salary until a sentence of culpability was given against him. Finally, she added that her condition of a royal officer’s consort and a former archbishop's niece made her incapable of asking for charity or live in need.

This argument clearly demonstrates that people elaborated their demands based on notions of what they deserved according to their social standing. Doña Constanza demanded preferential treatment as both the wife, and later widow, of a royal officer and niece of a former archbishop. She highlighted that her social status did not permit her to

\footnotetext{
${ }^{454}$ Request of Doña Constanza to the Visitador to receiving the salaries of her husband, Lima, March 5, 1683. AGI, Lima, 288.
} 
live from charity. She was appealing to caustic jurisprudence, which ruled according to the specificities and statuses of the people involved in the case.

In her petition, she combined notions of law and custom. She argued that her husband had not lost rights over his salaries because a final sentence on his functions as royal officer was still pending. This was an argument based on law, which required a final sentence to apply the punishment. She attempted to devalue accusations against her husband, arguing that they were crafted based on enmity and animosity. It was customary practice, and legally accepted, that a defendant could undermine adversary testimonies on the grounds that they were provided by personal enemies.

Finally, Doña Contanza’s request appealed to the preeminence that divine and natural law had over the king's individual order in her husband's case. Her arguments did not deny her loyalty to the king or challenge his authority. When she highlighted the legal recourse of "Obedezco, pero no cumplo," she pointed out that the king himself recognized divine and natural right as prevalent. According to Doña Constanza's legal elaboration, the king himself had crafted a legal mechanism that both validated supreme law and his authority.

Visitador Peñalosa, however, rejected all of these arguments and ruled against all of the various requests Doña Constanza presented, even after years her husband had died. He 
argued that evidence confirmed Navarrete's faults during his administration, so it was imperative to sequester his salary because it came "from the king's purse." 455 Doña Constanza had to wait many more years to get the results of the visita and a resolution to her requests.

In 1693, when the visitor had the final report listing the amounts owed by the caja reales’ royal officers from 1620 to 1685 , Navarrete was responsible for a debt of 30,590 pesos 5 reales. ${ }^{456}$ This was a substantial amount considering that the senior officers of the caja real earned annual salaries ranging between 3000 and 3500 pesos. ${ }^{457}$ One more time, Navarrete's family demanded the restitution of the salaries, which they argued belonged to Don Sebastian until his death, to pay part of the debt. ${ }^{458}$ Yet the demands by Navarrete's family became fruitless when the visitor discovered that Navarrete had hidden from

${ }^{455}$ Decree of the Fiscal of the Real Audiencia, Lima, April 13, 1683. AGI, Lima, 288.

${ }^{456}$ Copy of the general report of the amounts owed by the officers according to the declaration of debts from 1620 to 1685 . May $20^{\text {th }}$, 1693. AGI, Lima, 288. Navarrete was responsible for a debt of 22,819 pesos y 4 reales of pesos of 8 reales, and 4697 pesos two tomines one cuartillo of pesos ensayados.

${ }^{457}$ Luque, Funcionarios y remuneraciones, 94.

${ }^{458}$ Request of Don Fernando de Castro, husband of Doña Leonor Silvestra de Navarrete, s/f. AGI, Lima,291. 
inspectors a rural estate, which he entrusted to the Maestre de Campo Don Fernando Nuñez

de Sanabria. ${ }^{459}$ When Peñalosa found this property, it undermined the comptroller's claims

of loyal service to the king and confirmed the multiple accusations against him.

\section{Conclusion}

Certainly, the visita did not meet the expectations of the peninsular ministers and the King because it was unable to completely resolve the chaotic condition of the Peruvian treasury. There were various obstacles to the activities and improvements that a handful of officers could make, such as collecting large and old debts, factionalism between royal officers, ties to local interests, and more. The colonial government of Lima, as in other parts of the Spanish empire, had several royal officers who failed to accomplish the duties of their posts or committed excesses while they generated certain benefits to the crown. Navarrete was a clear example of the latter; however, there were other ministers that behaved similarly yet never received the same punishment.

Nonetheless, the late Hapsburg administration did not passively accept the misconduct or errors of representatives in the colonies. The visita to the Cajas Reales of Lima in the late seventeenth century demonstrates that the Spanish government had not

${ }^{459}$ Letter of Juan de Peñalosa to the King, Lima, September $15^{\text {th }}, 1696$. AGI, Lima,288. 
lost its capacity to bring officers, and institutions under control and order. The notable decrease of the total debts of the caja real of Lima, the imprisonment of Navarrete, and the final sentence against the royal officers demonstrate that the visita gained some centralized control and, most importantly, increased some of the productive capacity of the colony.

The prosecution of Navarrete demonstrates that the Spanish administration was not impotent or unable to control its royal representatives. This early modern system permitted flexibility of governance to officeholders. Nonetheless, flexibility had limits that officers could not breach without risking punishment or even their lives. Officeholders, as well as other royal subjects, developed their own notions of justice and legitimacy. They enjoyed the privileges of their post and demanded specific treatment according to their position. Nonetheless, in their quest to prove loyalty to the crown, they ultimately understood that their authority came from the king. Even if they were thousands of miles away from the monarch, he was the source that legitimated their authority.

Navarrete and his wife, as well as many other corporative bodies and individuals seen in the previous chapters, expected a certain type of treatment from authorities based on their social standing. They understood that authorities should impart justice according to people's social standing after a careful analysis of law and custom. If people effectively 
contributed to new notions of justice when crafting their own legal arguments, it was the state apparatus and its representatives that ultimately set and applied justice in the end.

\section{CONCLUSION}

The concepts of crisis and decline have pervaded the history of Spain since the sixteenth century. Studies by foreign and Spanish intellectuals, particularly since the eighteenth century, have reduced Spain’s seventeenth century to a tale of crises, associating the destiny of its empire with the destiny of the ruling Hapsburg dynasty. More recent scholarship, employing new approaches and examining new research topics about the seventeenth century, have not completely dispelled the specter of Spanish 
crisis. What is more, the specter of a weak or deficient Spanish Hapsburg state also lives on in popular intellectuals’ writings. ${ }^{460}$

Yet, within these new waves of scholarship lie clues that suggest that the time has come for scholars to reappraise the Hapsburg decline narrative. According to the "crisis" theorists, one of the main signs of crisis was in Spain’s government and administrative structure and political culture, which have been defined as inept, inefficient, and unable to impose central authority on the extensive domains of the Spanish empire. But this representation of Spanish administration, in both the metropolis and its colonies, comes from comparing the Spanish state not to contemporary early modern governments but to modern nation-states.

When placed in its proper context, it is clear that the Spanish imperial state was a patrimonial system well aligned with its times. Governmental practices and rules, however flexible in practice, were ultimately legitimated by the monarch's royal power, and in turn contributed to the legitimacy of Spanish imperial rule. Even when bureaucrats' authority emanated from the king, their performance was limited by local interests and ordinary subjects’ perceptions of justice. The overlapping jurisdictions of

460 John Elliot, “The Decline of Spain,” Past \& Present 20 (Nov., 1961), 73. 
bureaucrats and institutions, extensive corpuses of laws, and the value of the customary practices required constant negotiation and compromise from royal agents and colonial subjects. Other early modern states, such France and English, also relied on continual negotiation because it was necessary to obtain the support of local elites to implement the central government's new policies. Negotiation allowed the inhabitants of early modern societies — and particularly the heterogeneous inhabitants of Spain's colonies-- to defend their purported privileges or seek protections according to the role they played in the socio-political body.

Since the ultimate objective of early modern administration did not aim to fulfill the common good but provide to each part of society with what was "conveniente," or appropriate, the application of laws was not universal but applied on a case-by-case basis. Judges sought to reach mutually beneficial sentences for the parties involved in a suit, requesting determined procedures according to each case.

When rules contradicted practice, solutions were reached and legitimated following the same objective of "conveniencia". "Conveniencia" was not dictated by the interest of powerful figures alone but by reference to a greater sense of fairness for all actors involved. For instance, when the interim comptroller De los Santos demanded 
rights over the fees that Navarrete traditionally collected when expediting royal treasury's receipts, the visitador rejected the idea, concerned that it was not just. In spite of the fact that both parties recognized the customary collection of such fees as valid, the visitador denied its legitimacy because those fees unfairly burdened the large number of individuals that requested receipts from the royal treasury to confirm payments. Understanding the Spanish empire within the paradigm of the patrimonial state offers new perspectives on the performance of the royal administrators and the political system implemented by the Spanish Hapsburgs in the New World, particularly in a moment of intense crisis. The performance of royal agents after the earthquake was dynamic and the capacity of the crown to impose control and authority was substantial, even after the destruction of the capital by the severest earthquake up to that moment in the colonial life of the city.

The ability to respond dynamically and with flexibility might have been showcased after the earthquake, but it was not new. The presence of pirates on the coast of the viceroyalty of Peru had for a century been a crisis that popped up from time to time, beginning with the first English corsairs circumnavigated the Straits of Magellan. Most of the planning and construction of the series of defensive structures along the 
coastline of the main port Callao resulted from the imminent threat of pirates on the viceroyalty’s capital. Despite of the importance of this port for the colonial administration and economy, viceroys hesitated to build these structures because of the economic burden they represented for the royal treasury. The royal authorities demonstrated more concern on sending bullion remittances to the metropolis than on improving the defenses of the viceroyalty's main port.

The wall of Lima finally was constructed in the seventeenth century after a new wave of pirate raids in the South Sea and the entrance of one of the principal actors in this dissertation, Viceroy Duke of Palata. He had to design a new plan not only for the construction of the structure but also the cost of future repairs. In order to reduce the costs of the wall, he obtained economic and personal contributions from the different members of Lima's corporate groups. With the creation of new taxes, the Duke attempted to relieve financial pressure on Peru's royal treasury.

Similar to his predecessors, the Duke’s main responsibility was to send periodical remittances of bullion to the King. His performance during the reconstruction of Lima after the quake of 1687 demonstrated the continued concern in protecting the royal finances above all else. Like other early modern officeholders, the Viceroy was in charge 
of implementing the crown's instructions; yet he realized that, in order to protect the royal treasury, he had to negotiate the expenses related to construction projects with the colonial population that they directly benefited. Negotiation was an effective tool for the Viceroy to obtain economic support from corporative groups to build the devastated city wall and consent from royal officers to construct a smaller viceregal palace.

The wall of Lima did little to protect the capital against the attacks of nature. Some sections crumbled on top of adjacent properties when the Earthquake of 1687 hit, and there was damaged property and dispossession all over the city. Amid the disorder and destruction of the city, the Duke rapidly ordered the other royal officers to deal with critical matters such as the dispersion of the population, distribution of food, and the clearing of dead bodies and rubble. The Viceroy and the city counselors met in a provisional cabin built in the Plaza Mayor, and planned and promulgated the essential measures to respond to the immediate needs of the population. The colonial administration in Lima was both primed for the event and flexible enough to react to the new circumstances they faced.

Because of the destruction of the viceregal palace, which was headquarters of the main branches of the colonial administration, most government institutions suspended 
their activities for some months. For this reason, the Viceroy organized the recovery and reconstruction of the city by enlisting the members of the city council. The viceroycabildo alliance implemented new measures to deal with the new needs of the populations, such as the provision of good, fair food prices, and access to affordable labor force and materials to rebuild properties.

Once the Viceroy organized the immediate response to the critical situation of the city, he focused on the activities of reconstructing those buildings that embodied the authority of the crown, including the viceregal palace, the city council, and the cathedral, among others. Once again, he had to undertake his tasks while causing the minimum burden on the royal treasury.

The earthquake interrupted the plans the Duke had made to support the council's long-term finances. In order to create new income to pay off the rebuilding of the city council, the Viceroy conferred it another land grant. Meanwhile, the counselors tried to raise more funds through the penalties imposed on the food suppliers, construction laborers, and suppliers of construction materials that did not follow the new regulations of the council. These attempts to reduce the cost of constructing the viceregal palace and improve the city council's budget demonstrate that royal administrators were judicious, 
innovative and not inept. They recognized the colonial institutions’ problems and developed new means to deal with them. In order to implement these innovations, royal officers carefully weighed both benefits and risks of potential measures.

The rebuilding of the cathedral represented not only another challenge to the Viceroy, but uncovered cracks within the highest echelons of the secular religious hierarchy. The performance of the prelates during weeks and months after the quake paled against the active participation of the members of the regular clergy. Members of the different religious orders actively participated in the spiritual assistance of people as soon as the first quake passed. Meanwhile, the members of the ecclesiastical council spent months discussing the construction of a decent provisional chapel at the Plaza Mayor, where they would be able to perform their regular duties. They seemed more concerned about building a decent chapel in accordance with their social condition than with fulfilling their spiritual obligations. The Archbishop of Lima remained absent for several weeks after the quake, recovering from injuries sustained when the earthquake hit. In his absence, the Viceroy assumed religious functions such as organizing processions, performing penitence acts, and attending sermons. 
When the Viceroy assembled the Archbishop and members of the ecclesiastical council to discuss the reconstruction of the cathedral, they refused to accept any of his suggestions to raise funds for the rebuilding activities. The Viceroy’s first step was to deliberate, determine what was most suitable for the Church, and reach consensus. When no agreement was reached, the colonial administration resorted to other available mechanism to persuade stubborn opponents to comply. Since the Viceroy initially was unable to reach his objectives through negotiation, he finally escalated the issue to the highest level of ecclesiastical authority that granted a positive resolution for the royal treasury. In other words, despite the inflexible resistance from the ecclesiastical ministers, the colonial administration was able to compel them to contribute to the cathedral's reconstruction through effective means.

The reconstruction of Lima's private property also reveals a customary practice of negotiation among ordinary people, as well as the adoption and adaptation of official and unofficially forms of the Spanish legal system. People from different social conditions negotiated and set formal and informal contracts to rebuild property. In court, individuals elaborated and set reconstruction plans with the mediation of judges, while notaries mainly validated agreements previously negotiated by the parties. Courts and notaries 
were the official spaces the colonial subjects used to legitimate agreements. The rebuilding projects contained in these official contracts are similar in that they all dealt with reconstruction of property, yet each case proposed specific solutions or plans according to its own particularities, replicating the larger casuistic culture of law.

Alongside these official contracts, colonial subjects also reached and implemented informal agreements. Unlike the cases presented before judges and notaries, which usually involved large sums of money in properties, unofficial contracts dealt with smaller sums of money and were resolved between the parties involved without an overseeing authority; yet they pursued the same objectives of rebuilding a property in that they benefited or satisfied both the owner and the tenant. A judge or notary did not legitimize these informal contracts, yet they were valid for the parties involved.

The different cases presented show that ordinary people in Lima, standing in the destroyed rubble of their city, actively rebuilt not only buildings but also the colonial state using the cultural materials they had on hand—namely legal negotiation. They adopted the formal forms the Spanish legal system had implemented in the New World and also adapted them to fit their own needs. The unofficial contracts mirrored the official ones in both the objectives pursued and the flexibility they provided to 
individuals to elaborate their own rebuilding projects. These contracts also demonstrate how limeños engaged broader discourses before colonial authorities about what was fair or unfair in terms of fulfilling certain contractual obligations amid the critical conditions of the city, while devising “conveniente” resolutions to the parts involved.

Finally, by moving backward in time, to the visita general to the cajas reales of Lima during the reign of Charles II, the dissertation reveals that, while the contours of patrimonialism fit colonial society well, not everything was always perfect. The crown and its agents recognized the necessity of reforming and improving the performance of various institutions and officers of royal administration. The inspection of Lima's treasury lasted several years, and various inspectors took the responsibility of scrutinizing the institution and its officials. Until now, the accomplishments of this visita have been lost in history. The Earthquake of 1687 halted fiscal reform plans Duke of Palata first introduced in the city, and brought an end to the increased collecting activities of the royal administrators. But in the short period of the Duke's tenure as viceroy, the condition of the viceroyalty royal treasury was significantly improved, and Lima's treasury debt was considerably reduced. 
Although the crown granted local administrators flexibility, negotiation also had its limits. The Spanish early modern state had the tools necessary to impose control and authority when officeholders exceeded their power. For instance, Sebastian de Navarre was imprisoned, his belongings confiscated, and finally exiled to New Spain, where he died without defending his case after he fell from royal grace. But Navarrete's response also reveals that crown subjects believed that their social status—so important in a patrimonial state - might provide relief from royal scrutiny. Before departing to Acapulco, he had collected abundant certifications of the various services he had performed for the king. He did not attempt to disprove negligence in the performance of his post's duties, but constantly stressed that his administrative activities, although questionable, generated benefits for the royal treasury. After Navarrete left Lima, and even after he finally died in Mexico, his wife, Doña Constanza de Navarrete, continued disputing the confiscation of his salaries and her dowry. She based her demands on legal and customary practices and argued that her husband had not been found guilty or sentenced yet; therefore, he was entitled to his salaries in order to support his family.

Just as the members of the ecclesiastical council that claimed it was impossible to contribute to the cathedral's rebuilding because their social status did not allow them to 
live decently with reduced incomes, Don Sebastián and Doña Constanza elaborated their requests for royal favor according to the social "quality." If read carefully, the arguments by the prelates, and Don Sebastian and Doña Constanza, together demonstrate that members of the colonial society shared a common framework in which law and custom had to conform to the demands of social class and status. The validity of both law and custom permitted individuals to build their own discourses of justice, which captured their understanding of the privileges they deserved according to their station in the sociopolitical body. Even those individuals that appeared before judges and notaries in order to obtain legitimate resolutions to their building needs developed discursive assertions of fairness and "conveniencia." Colonial subjects' use of broader patrimonial practices and values, including discourses of law, and extralegal contracts and practices, reveals a dynamic, open and strong colonial system. The lack of a rigid centralization allowed flexibility, and thus royal administrators and ordinary people could creatively contend with crisis, innovating during times of hardship by combining legal and extralegal practices to rebuild. Contrary to the image of decadence or incapacity, the Hapsburg colonial state in Lima responded effectively to the earthquake, sustained various fiscal reforms, and improved the critical 
condition of the royal treasury. Ultimately, the flexibility of the system bolstered the common framework of colonial rule so that it was able to withstand even a devastating event.

Rather than halting the Hapsburg reforms, the earthquake simply temporarily suspended them. Royal agents redirected their attention to the immediate needs of the population, and the reorganization of the capital's administration and reconstruction. Lima was able to recover as everyone, colonial authorities and colonial subjects, tacitly put themselves in a fast-forward mode to cope with the new circumstances of the city. The earthquake did not undermine the colonial state but instead strengthened it. When the ground shifted under their feet, Lima's residents kept themselves steady by leaning on the practices and discourses of the Spanish colonial system in order to rebuild their city. 


\section{BIBLIOGRAPHY}

\section{1) Primary Sources}

\section{PERU}

Archivo Arzobispal de Lima:

Serie Cofradías

Serie Convento Santa Clara

Serie Convento de la Encarnación

Serie Monasterio de la Pura y Limpia Concepción

\section{Archivo Catedralicio de Lima:}

Actas del Cabildo Eclesiástico

Cuentas de la Fábrica de la Catedral

\section{Archivo General de la Nación:}

Fondo Asuntos Eclesiásticos 
Protocolos Notariales

Sermones

Tribunal Eclesiástico

Archivo Histórico de la Beneficencia de Lima:

Libros de la Cofradía del Santísimo Sacramento

Archivo Histórico de la Municipalidad Metropolitana de Lima:

Actas del Cabildo de Lima

\section{SPAIN}

\section{Archivo General de Indias}

Lima, 87

Lima, 280

Lima, 281

Lima, 290

Lima, 296

Lima, 520

Codices, L. 752

Contaduría, 1780B

Contaduría, 1781

Mexico, 54, R.1,N.14.

\section{Biblioteca Nacional Madrid}

MS. 9375, Carta que el padre Fray Domingo Álvarez de Toledo Procurador General de Corte de la orden de Nuestro Padre San Francisco escribió desde Lima al Reverendísimo Padre General en este chasque, October 29, 1687.

MS 9375, Carta del Duque de la Palata al Rey, December 8, 1987.

MS. 18760/36, Relación del Temblor que sucedió en Lima lunes 20 de octubre de 1687. 
VE - 1461/1. Relación del Ejemplar Castigo que envió Dios a la ciudad de Lima con los espantosos temblores de 20 de octubre de 1687.

VE 1478 - 4. Ivan del Valle y Caviedes, Romance en que se Procura pintar, y no se consigue; la Violencia de dos terremotos, con que el Poder de Dios asolo esta Ciudad de Lima, Emporeo de las Indias Occidentales, y la mas rica del Mundo,

\section{2) Printed Primary Sources}

Recopilación de las Leyes de los Reynos de Indias, edited by Ignacio Boix. Madrid: 1841.

Buendía, Joseph de. "Relación del temblor que arruinó a Lima el 20 de octubre de 1687." In Terremotos. Colección de las relaciones mas notables que ha sufrido esta capital y que la han arruinado, edited by Manuel de Odriozola. Lima: Tipografía de A. Alfaro, 1863.

Cueva, Baltazar de la, "Relación General que el Excelentísimo Señor Conde de Castellar, Marques de Malagón, Gentil Hombre de la Cámara de su Majestad, de su Consejo, Cámara y Junta de Guerra de Indias, virey, Governador y Capitán General que fué de estos reinos, hace del tiempo que los gobernó, estado en que los dejó, y lo obrado en las materias principals con toda distinction.” In Memorias de los Virreyes que han gobernado el Perú durante el tiempo del coloniaje español, edited by Manuel Atanasio Fuentes. Lima: Librería Central de Felipe Bailly, 1859.

Mugaburu, Josephe de, and Francisco de Mugaburu. Diario de Lima (1640 - 1694): Crónica de la época colonial. Lima: Imprenta C. Vasquez, 1935.

Navarra y Rocafull, Melchor de. “Memoria de Gobierno, 16 de agosto de 1689.” In Los virreyes que han gobernado el Perú durante el tiempo del coloniaje español, edited by Manuel Atanasio Fuentes. Lima: Librería Central de Felipe Bailly, 1859.

Toledo y Leiva, Manuel de. “Memoria de Gobierno.” In Memorias de los Virreyes del Perú: Marqués de Mancera y Conde de Salvatierra, edited by José Toribio Polo. Lima: Imprenta del Estado, 1896. 


\section{3) Secondary Sources}

Adelman, Jeremy. "Introduction: The Problem of Persistence in Latin American History.” In Colonial Legacies. The Problem of Persistence in Latin America History, edited by Jeremy Adelman, 1-15. New York: Routledge, 1999.

Alexander, David. "The Study of Natural Disasters, 1977-97: Some Reflections on a Changing Field of Knowledge.” Disasters 21, 4 (Dec 1997): 284 - 304.

Álvarez Ponce, Victor. “El Mar y las Políticas Preventivas en el Perú Virreinal: Impacto, Control y Vulnerabilidad ante los Tsunamis (1647-1751).” MA Thesis: Pontificia Universidad Católica del Perú, 2014.

Andrien, Kenneth. Crisis and decadencia. El Virreinato del Perú en el siglo XVII. Lima: Instituto de Estudios Peruanos, 2011.

Andrien, Kenneth. "The Sale of Fiscal Offices and the Decline of Royal Authority in the Viceroyalty of Peru, 1633 - 1700,” Hispanic American Historical Review 62, 1 (1982): 49-71.

Araújo, Ana Cristina. “The Lisbon Eathquake of 1755. Public Distress and Political Propaganda,” E-Journal of Portuguese History 4, 1 (Summer, 2006): 1-11.

Arias de Saavedra, Inmaculada, Miguel Luis López, and Guadalupe Muñoz, “Las cofradías y su dimensión social en la España del Antiguo Régimen,” Cuadernos de Historia Moderna, 25, (2000): 189-232.

Barton, Allen H. Communities in Disaster: A Sociological Analysis of Collective Stress Situations. Garden City, New York: Doubleday \& Company, 1969.

Bailyn, Bernard. Atlantic History. Concept and Contours. Cambridge: Harvard University Press, 2005.

Bakewell, Peter. A History of Latin America. Oxford: Blackwell Publishers, 1997. 
Bernales Ballesteros, Jorge. Lima. La Ciudad y Sus Monumentos. Sevilla: Consejo Superior de Investigaciones Científicas, Escuela de Estudios Hispano-Americanos, 1972.

Bermúdez, José Manuel. Anales de la Catedral de Lima, 1534 a 1824. Lima: Imprenta del Estado, 1903.

Beik, William. Absolutism and Society in Seventeenth-Century France: State power and provincial aristocracy in Languedoc. New York: Cambridge University Press, 1985.

Benton, Lauren. Law and Colonial Cultures. Legal Regimes in World History, 1400 1900. Cambridge: Cambridge University Press, 2002.

Bergamini, John D. The Spanish Bourbons: The history of a tenacious dynasty. New York: Putman, 1974.

Bernardo Ares, José Manuel de. Luis XIV Rey de España. De los imperios plurinacionales a los estados unitarios, 1665-1714. Madrid: Lustel, 2008.

Bolaños, Alvaro Félix. “A Place to Live, a Place to think, and a Place to Die: Sixteenth Century Frontier Cities, Plazas, and ‘Relaciones’ in Spanish America.” In Mapping Colonial Spanish America. Places and Commonplaces of Identity, Culture, and Experience, edited by Santa Arias and Mariselle Meléndez, 275-293. London: Associated University Presses, 2002.

Braddick, Michael. State Formation in Early Modern England, c. 1550-1700. Cambridge: Cambridge University Press, 2000.

Bradley, Peter T. Spain and the Defense of Peru, 1579 - 1700: Royal Reluctance and Colonial Self-Reliance. Lexington: Lulu.com, 2009.

Burnham, John C. “A Neglected Field: The History of Natural Disasters,” Perspectives 26 (April, 1988): 22-24

Burkholder, Mark. Spaniards in the Colonial Empire: Creoles vs. Peninsulars? Malden, MA: Wiley-Blackwell, 2013. 
Burkholder, Mark A. and D. S. Chandler. From Impotence to Authority: The Spanish Crown and the American Audiencias - 1687-1808. Columbia: University of Missouri Press, 1977.

Burneo, Reinhard Augustin. Las Murallas Coloniales de Lima y el Callao. Lima: Editorial Universitaria, 2012.

Burns, Kathryn. Into the Archive. Writing and Power in Colonial Peru. Durham: Duke University Press, 2010.

Bustos Navarrete, Julio. Estudio Sismológico de Chile: con los temblores y terremotos producidos en los últimos cuatro siglos. Santiago: 1931.

Cañeque, Alejandro. The King's Living Image. The Culture and Politics of Viceregal Power in Colonial Mexico. New York: Routledge, 2004.

Capello, Ernesto. City at the Center of the World. Space, History, and Modernity in Quito. Pittsburg: University of Pittsburg Press, 2011.

Cardim, Pedro, Tamar Herzog, José Javier Ruiz Ibáñez and Gaetano Sabatini, Polycentric Monarchies: How Did Early Modern Spain and Portugal Achieve a Global Hegemony? (Brighton, UK: Sussex Academic Press, 2012).

Cardoso, José Luis. “El Terremoto de Lisboa de 1755 y la política de regulación económica del Marqués de Pombal,” Historia y Política, 16 (2006): 209-236.

Carrera Pujal, Jaime. Historia de la Economía Española, vol. 2. Barcelona: Bosch Casa Editorial, 1944.

Caviedes, César. El Niño in History: Storming through the Ages. Gainesville: University Press of Florida, 2001.

Centeno, Miguel Angel and Agustin E. Ferraro, State and Nation Making in Latin America and Spain: Republics of the Possible. New York: Cambridge University Press, 2013. 
Chance, John K. Race and Class in Colonial Oaxaca. Stanford: Stanford University Press, 1978.

Chubbs, Judith. "Three Earthquakes: Political Response, Reconstruction, and the Institutions: Belice (1968), Friuli (1976), Campania (1980).” In Disastro! Disasters in Italy Since 1860: Culture, Politics, Society, edited by John Dickie, John Foot and Frank M. Snowden, 186-233. New York: Palgrave, 2002.

Clancey, Gregory. Earthquake Nation: The Cultural Politics of Japanese Seismicity, 1868 -1930. Berkeley: University of California Press, 2006.

Coello de la Rosa, Alexandre. “La Destrucción de Ninive: Temblores, Políticas de Santidad y la Compañía de Jesús (1687 - 1692)” Boletín Americanista, LVIII, 58 (2008): 149-169.

Cole, John P. Estudio Geográfico de la gran Lima. Lima: Oficina Nacional de Planeamiento y Urbanismo, 1957.

Cook, N. David, and Alexandra Parma Cook. The plague files: crisis management in sixteenth-century Seville. Baton Rouge: Louisiana State University Press, 2009.

Cook, N. David. La Catástrofe demográfica andina. Perú 1520 - 1620. Lima: Fondo Editorial Pontificia Universidad Católica del Perú, 2010.

Corrigan, Philip, and Derek Sayer. The Great Arch. English State Formation as Cultural Revolution. Oxford: Basil Blackwell, 1985.

Costa, Miguel. "Patronage and Bribery in Sixteenth Century: The Government of Viceroy Conde del Villar and the Visita of Licentiate Alonso Fernandez de Bonilla.” PhD Diss., Florida International University, 2005.

Crahan, Margaret Ellen. “Clerical Immunity in the Viceroyalty of Peru, 1684-1692: a study of civil-ecclesiastical relations.” PhD diss., Columbia University, 1967. 
Crahan, Margaret. “The Administration of Don Melchor de Navarra y Rocafull, Duque de la Palata: Viceroy of Peru, 1681-1689.” The Americas 27, no. 4 (April 1971): 389412.

Deeds, Eric. "Church History: Institutions and Archives." In Guide to Documentary Sources for Andean Studies, 1530 - 1900, edited by Joanne Pillsbury, vol. 1, 163-188. Norman: University of Oklahoma Press, 2008.

Dickie, John. "The Smell of Disaster: Social Collapse in the Aftermath of the MesinaRegio Calabria Earthquake 1908.” In Disastro! Disasters in Italy Since 1860: Culture, Politics, Society, edited by John Dickie, John Foot and Frank M. Snowden, 235-255. New York: Palgrave, 2002.

Doering, Juan Günther and Guillermo Lohmann Villena. Lima. Madrid: Colecciones MAPFRE, 1992.

Elliot, John. Spain, Europe \& the Wider World, 1500-1800. Haven: Yale University Press, 2009.

Elliot, John. Empires of the Atlantic World. Britain and Spain in America, 1492-1830 (New Haven: Yale University Press, 2006).

Elliot, John. Imperial Spain, 1492 - 1716. New York: New American Library, 1963.

Elliot, John. “The Decline of Spain.” Past \& Present 20 (Nov., 1961): 52-75.

Espinosa Cortés, Luz María. “Oaxaca: Desastres, Hambre y Epidemias Entre los Pueblos ‘Criadores’ de Grana Cochinilla, 1760-1781.” In Cuba y México: Desastre, Alimentación y Salud. Siglos XVIII-XIX. Estudios de Caso, compiled by Luz María Espinosa Cortés and Enrique Beldarraín Chaple, 141-199. Mexico D.F.: Plaza y Valdés, 2005.

Espinoza Ríos, Javier Augusto. Las Finanzas el Fervor. Las Prácticas económicas en el Monasterio de Santa Clara de Lima, 1621-1682. MA Thesis: Pontificia Universidad Católica del Perú, 2012. 
Fernández Canque, Manuel. Arica 1868: un tsunami y un terremoto. Santiago: Dirección de Bibliotecas, Archivos y Museos, 2007.

Fernández de Béthencourt, Francisco. Historia Genealógica y Heráldica de la Monarquía Española: Casa Real y Grandes de España, vol. 3. Madrid: Establecimiento Tipográfico de Enrique Teodoro, 1901.

Flores, Ramiro. "El enemigo frente a las costas. Temores y reacciones a la amenaza pirate, 1570-1720.” In El Miedo en el Perú. Siglos XVI al XX, edited by Claudia Rosas, 33-50. Lima: Fondo Editorial de la Pontificia Universidad Católica del Perú, 2005.

Foucault, Michael. “Governmentality.” In The Foucault effect. Studies in Governmentality with two lectures by and interview with Michael Foucault, edited by Graham Burchell, Colin Gordon, and Peter Miller, 87-104. Chicago: The University of Chicago Press, 1991.

Fradkin, Philip L. The Great Earthquake and Firestorms of 1906: How San Francisco Nearly Destroyed Itself. Berkeley: University of California Press, 2005.

García Acosta, Virginia. Historia y desastres naturales en América Latina. Lima: Red de Estudios Sociales en Prevención de Desastres en América Latina, 1996

García Pérez, Rafael. "Revisiting the America’s Colonial Status under the Spanish Monarchy.” In New Horizons in Spanish Colonial Law: Contributions to Transnational Early Modern Legal History, edited by Thomas Duve and Heikki Pihlajamäki, 29-73. Frankfurt: Max Planck Institute for European Legal History, 2015.

Gayol, Victor. Laberintos de justicia: Procuradores, escribanos, y oficiales de la Real Audiencia de México (1750-1812), Vol. I. Zamora: El Colegio de Michoacán, 2007.

Geschwind, Carl Henry. California Earthquakes: Science, Risk, and the Politics of Hazard Mitigation. Baltimore: John Hopkins Press, 2001.

Gil Pujol, Xavier. “Pensamiento politico español y europeo en la Edad Moderna. Reflexiones sobre su estudio en una época post-whig.” In Campo y campesinos en la España Moderna. Culturas Políticas en el Mundo Hispano, edited by María José Pérez 
Álvarez and Alfredo Martín García, 207-222. León, Spain: Fundación Española de Historia Moderna, 2012.

Grafe, Regina. Distant Tyranny. Markets, Power, and Backwardness in Spain, 1650 1800. Princeton: Princeton University Press, 2012.

Hamilton, Earl. "Revisions in Economic History: VIII. The Decline of Spain.” The Economic History Review 8, No. 2 (May, 1938): 168-179.

Hamilton, Earl. War and prices in Spain, 1651 - 1800. Cambridge: Harvard University Press, 1947.

Hanska, Jussi. Strategies of Sanity and Survival. Religious Responses to Natural Disasters in the Middle Ages, Studia Fennica Historica 2. Helsinki: Finnish Literature Society, 2002.

Hargreaes - Mawdsley, W. N. Eighteenth - Century Spain 1700 - 1788. Totowa, N.J.: Rowman and Littlefield, 1979.

Herzog, Tamar. Upholding Justice: Society, State, and the Penal System in Quito (1650 1750). Ann Arbor: The University of Michigan Press, 2004.

Hirshleifer, Jack. Economic Behavior in Adversity. Chicago: The University of Chicago Press, 1987.

Isenberg, Andrew C. "Introduction: New Directions in Urban Environmental History.” In The Nature of Cities, edited by Andrew C. Isenberg, xi-xix. Rochester: University of Rochester Press, 2006.

Jímenez, Ismael. "Don Alvaro de Ybarra: el Criollo más poderoso de su tiempo (16211675).” In América en la Memoria: Conmemoraciones y Reencuentros edited by Begoña Cava Mesa, 307-325. Bilbao: Universidad de Deusto, Asociación Española de Americanistas, 2013.

Johnson, Sherry. "The St. Augustine Hurricane of 1811: Disaster and the Question of Political Unrest on the Florida Frontier.” The Florida Historical Quarterly 84, No. 1, Special H-Florida Issue: Florida History from Transnational Perspectives (Summer, 2005): 28-56. 
Jurado Jurado, Juan Carlos. “Terremotos, pestes y calamidades. Del Castigo y la misericordia de Dios en la Nueva Granada (Siglos XVIII y XIX),” Revista de Historia Iberoamericana,4, 1(2011): 25-49

Kamen, Henry, “The Decline of Spain: A Historical Myth?” Past \& Present, 81 (Nov. 1978): 24-50.

Kamen, Henry. Spain in the Later Seventeenth Century, 1665 - 1700. London: Longman, 1980.

Kamen, Henry. Spain, 1469 - 1714. A Society of Conflict. London: Pearson, 2005.

Kern, William. “Introduction.” In The Economics of Natural and Unnatural Disasters, edited by William Kern, 1-7. Kalamazoo: W.E Upjohn Institute for Employment Research, 2010.

Kinsbruner, Jay. The Colonial Spanish-American City. Urban Life in the Age of Atlantic Capitalism. Austin: University of Texas Press, 2005

Kuethe, Allan, and Lowell Blaisdell. "French influence and the Origins of the Bourbon Colonial Reorganization.” Hispanic American Historical Review 71, No. 3 (Aug., 1991): 579-607.

Lavalle, Juan Antonio de, Domingo de Vivero, and Evaristo San Cristóbal. Galería de Retratos de los Gobernadores y Virreyes del Perú (1532-1824) Lima: Librería Clásica y Científica, 1891.

Lavrin, Asunción. "El Capital Eclesiástico y Las Elites Sociales en Nueva España a fines del XVIII,” Mexican Studies/Estudios Mexicanos 1, № 1 (Winter, 1985): 1-28.

Lévano, Diego. “Organización y Funcionalidad de las Cofradías Urbanas. Limas siglo XVIII,” Revista del Archivo general de la Nación, 22 (2001): 77-118.

Lohmann Villena, Guillermo, “La Ilustre Hermandad de Nuestra Señora de Aranzazu de Lima.” In Los vascos y América. Ideas, hechos, hombres. Actas de las Jornadas sobre el comercio vasco con América en el siglo XVIII, y la Real Compañía Guipuzcoana de 
Caracas en el II Centenario de Carlos III, 203-213. Madrid: Fundación Banco de Bilbao y Vizcaya, 1990.

Lohmann Villena, Guillermo. “Murallas y Fortificaciones del Perú Durante el Virreinato.” In Atlás Histórico y Geográfico del Perú: Descubrimiento, Conquista y Virreinato, tomo 2, 179-200. Lima: Editorial Milla Batres S.A., 1996.

Lohmann Villena, Guillermo. Las Defensas Militares de Lima y Callao. Lima: Academia Nacional de la Historia del Perú, 1964.

Lynch, John. Spain under the Habsburgs, vol. 2. Oxford: Basil Blackwell, 1969.

Lynch, John. Bourbon Spain, 1700 - 1808. Oxford: Basil Blackwell, 1989.

Lynch, John. “The Institutional Framework of Colonial Spanish America.” Journal of Latin American Studies, 24, Quincentenary Supplement: The Colonial and Post Colonial Experience. Five Centuries of Spanish and Portuguese America (1992): 69-81.

Luque, Juvenal. Funcionarios y remuneraciones. Salarios de la Caja Real de Lima en los siglos XVII y XVIII. Lima: Banco Central de Reserva del Perú, Instituto de Estudios Peruanos, 2011. McAlister, Lyle. Spain and Portugal in the New World: 1492 - 1700. Oxford: Oxford University Press, 1984.

MacKay, Ruth. "Lazy, Improvident People”: Myth and Reality in the Writing of Spanish History. Ithaca: Cornell University Press, 2006.

Maltby, William S. The Black Legend in England. The development of anti-Spanish sentiment, 1558 - 1660. Durham: Duke University Press, 1971.

Mans, Patricio. Los terremotos chilenos, 2 vol. Santiago: Ediciones Quimantú, 1972.

Mansilla, Judith. "Poder y prestigio social en las cofradías de españoles, siglos XVII y XVIII.” In Corporaciones religiosas y Evangelización en Ibero - América. Siglos XVI XVII, edited by Diego Levano and Kelly Montoya, 229-260. Lima, Universidad Nacional Mayor de San Marcos, 2001 
Marcos Martín, Alberto “ ¿Fue la fiscalidad regia un factor de crisis den la Castilla del siglo XVII?” In La crisis de la Monarquía de Felipe IV, coordinated by Geoffrey Parker, 173254. Barcelona: Editorial Crítica, 2006.

Marks, Patricia. Deconstructing Legitimacy: viceroys, merchants, and the military in late colonial Peru. University Park: Pennsylvania State University Press, 2007.

McAlister, Lyle. Spain and Portugal in the New World: 1492 - 1700. Oxford: Oxford University Press, 1984.

Mendiburu, Manuel de. Diccionario Histórico - Biográfico del Perú, vol. 7. Lima: Enrique Palacios, 1933.

Mendiburu, Manuel de. Diccionario Histórico - Biográfico del Perú, vol. 8. Lima: Enrique Palacios, 1933 - 34.

Meyers, Albert, "Religious Brotherhoods in Latin America.” In Manipulating the Saints: Religious Brotherhoods and Social Integration in Postcolonial Latin America edited by Albert Meyer and Diane Hopkins, 1-21. Hamburg: Wayasbah, 1988.

Molesky, Mark. This Gulf of Fire: The Destruction of Lisbon, or Apocalypse in the Age of Science and Reason. New York: Alfred A. Knopf, 2015.

Moore, John Preston. The Cabildo in Peru under the Hapsburgs: a study and powers of the Town Council in the Viceroyalty of Peru 1530 - 1700. Durham: Duke University Press, 1954.

Odriozola, Manuel de. Terremotos. Colección de las relaciones de los más notables que ha sufrido esta capital y que la han arruinado. Lima: Tipografía de Aurelio Alfaro, 1863.

Olson, Richard Stuart. "Towards a Politics of Disasters: Losses, Values, Agendas, and Blame.” International Journal of Mass Emergencies and Disasters 18 (August 2000): 275- 287. 
Olson, Richard Stuart and Vicente T. Gawronski, "Disaster as Crisis Triggers for National Critical Junctures? The 1976 Guatemala Case,” Latin American Politics and Society 55, 2 (Summer, 2013): 133-149.

O’Phelan Godoy, Scarlett. “La moda francesa y el terrmoto de Lima de 1746,” Boletín del Instituto Francés de Estudios Andinos, 36, 1 (2007): 19-38.

Osorio, Alejandra. Inventing Lima: Baroque Modernity in Peru's South Sea Metropolis. New York: Palgrave Macmillan, 2008.

Palacios Roa, Alfredo. “Dominio y Catástrofe. Los terremotos en Concepción, Chile: 15501751,” Anuario de Estudios Hispanoamericanos, 69, 2 (2012): 569-600.

Palacios Roa, Alfredo. "La Sensibilidad religiosa frente a las catástrofes naturales (1563 1730).” In Historia de la Iglesia en Chile: En los caminos de la conquista espiritual, vol. 1, edited by Rodrigo Moreno Jeria, directed by Marcial Sánchez Gaete, coordinated by Marco León León, 345-367. Santiago: Editorial Universitaria, 2009.

Palacio Roa, Alfredo. "Los terremoto, arquitectos por excelencia: Santiago de Chile 17301822.” Master’s Thesis, Universidad de Chile, 2007.

Paniagua Jesús. “Cofradías Limeñas: San Eloy y la Misericordia (1597-1733),” Anuario de Estudios Americanos, LII-1 (1995): 13-35.

Paquette, Gabriele. Enlightenment, Governance, and Reform in Spain and its empire. Cambridge: Palgrave Macmillan, 2011.

Geoffrey Parker and Lesley Smith, "Introduction.” In The General Crisis of the Seventeenth Century, edited by Geoffrey Parker and Lesley M. Smith, 1-32. Boston: Routledge \& Kegan Paul, 1978.

Parker, Geoffrey. "La crisis mundial del siglo XVII: Acontecimientos y 'paradigma.”” In La crisis de la Monarquía de Felipe IV, coordinated by Geoffery Parker, 19-54. Barcelona: Editorial Crítica, 2006. 
Parker, Geoffrey. Global Crisis. War, Climate Change \& Catastrophe in the Seventeenth Century. New Haven: Yale University Press, 2013.

Patrón, Pablo. Lima Antigua. Lima: Librería e Imprenta Gil, 1935.

Pearce, Adrian. The Origins of Bourbon Reform in Spanish South America, 1700-1763. Hampshire: Palgrave Macmillan, 2014.

Penick Jr., James. The New Madrid Earthquakes of 1811-1812 . Columbia: University of Missouri Press, 1976.

Pérez Cantó, María Pilar. “La Población de Lima en el siglo XVIII,” Boletín Americanista, 32 (1982): 383-407.

Pérez Mallaína, Pedro Emilio. Retrato de una Ciudad en Crisis. La Sociedad Limeña ante el movimiento sísmico de 1746. Lima: Pontificia Universidad Católica del Perú, 2001.

Pérez-Mallaína, Pablo Emilio. “Le pouvoir de l' etat les forces de la nature: la reconstruction de Lima apres le tremblement de terrede 1687.” In De Séville a Lima, edited by Alain Musset and Pablo Pérez Mallaína, 161 - 176. Paris: Université de Paris X - Nanterre, Laboratoire de Géographie Urbaine, 1997.

Phelan, John. "Authority and Flexibility in the Spanish Imperial Bureaucracy." Administrative Science Quarterly 5, No. 1 (Jun., 1960): 47-65.

Porras Barrenechea, Raul. Pequeña Antología de Lima. El río, el puente y la alameda. Lima: Universidad Nacional Mayor de San Marcos, 1965.

Premo, Bianca. Children of the Father King. Youth, Authority and Legal Minority in Colonial Lima. Chapel Hill: The University of North Carolina Press, 2005.

Priestley, Herbert Ingram. José of Gálvez. Visitador General of New Spain. Berkeley: University of California Press, 1916.

Quiroz, Alfonso. "Reassessing the Role of Credit in Late Colonial Peru: Censos, Escrituras, and Imposiciones,” Hispanic American Historical Review 74, 2 (May, 1994): 193-230. 
Quiroz Chueca, Francisco. "Movimientos de tierra y de piso: el terremoto de 1746, la corrupción en el Callao y cambios borbónicos,” Investigaciones Sociales-Historia, 3, 4 (1999), 37-50

Rawlings, Helen. The Debate on the Decline of Spain. Manchester: Manchester University Press, 2012.

Ribot, Luis. El Arte de Gobernar. Estudios sobre la España de los Austrias. Madrid: Alianza Editorial, 2006.

Ringrose, David. Spain, Europe, and the 'Spanish Miracle,' 1700-1900. Cambridge: Cambridge University Press, 1996.

Rodríguez, Joaquín. “Las cofradías de Perú en la modernidad y el espíritu de la Contrarreforma,” Anuario de Estudios Americanos, LII-2 (1995): 15 - 43.

Rosas Moscoso, Fernando. "El miedo en la historia: lineamientos generales para su estudio.” In El Miedo en el Perú. Siglos XVI al XX, edited by Claudia Rosas, 23-32. Lima: Pontificia Universidad Católica del Perú, 2005.

Roseberry, William. "Hegemony and the Language of Contention," Everyday Forms of State Formation: Revolution and the Negotiation of rule in Modern Mexico, edited by Gilbert Joseph and Daniel Nugent, 355-366. Durham: Duke University Press, 1994.

Saint, Pierre. Observaciones e interpretaciones de los terremotos chilenos. Santiago: Universidad de Chile, 1961.

San Cristóbal Sebastián, Antonio. Arquitectura de Lima en la segunda mitad del siglo XVII. Lima: Universidad San Martín de Porres Fondo Editorial, 2010.

San Cristóbal, Antonio. La Casa Virreinal Limeña de 1570 a 1687, tomo 1. Lima: Fondo Editorial del Congreso del Perú, 2003.

Sánchez Pedrote, Enrique. “Los prelados virreyes.” Anuario de Estudios Americanos 7 (1950): 211-53. 
Sanchez, Joseph. The Spanish Black Legend: origins of anti-Hispanic stereotypes. Albuquerque: National Park Service, Spanish Colonial Research Center, 1990.

Sánchez, Susy. "La frágil ciudad de los conquistadores. Movimientos sísmicos en Lima,” in Lima XVI, edited by Laura Gutiérrez Arbulú, 457-489. Lima: PUCP, 2005.

Sánchez, Susy. “Un Cristo Moreno conquista Lima: los arquitectos de la fama pública del Señor de los Milagros 1651-1771.” In Etnicidad y Discriminación Racial en la Historia, edited by Scarlett O’Phelan, 65-92. Lima: Fondo Editorial Pontificia Universidad Católica del Perú, Instituto Riva-Agüero, Banco Mundial, 2002.

Sánchez, Susy. “La ruina de Lima: mito y realidad del terrremoto de 1746. Master’s Thesis: Pontificia Universidad Católica del Perú, 2001.

Sanz Tapia, Ángel. Corrupcion o necesidad?: la venta de cargos de gobierno americano bajo Carlos II (1674-1700) Madrid: Consejo Superior de Investigaciones Científicas, 2009.

Sanz Tapia, Ángel. “Cargos politicos beneficiados en Hispanoamérica bajo Carlos II.” In Ciencia, Economía y Política en Hispanoamérica Colonial, coordinated by Antonio Gutiérrez Escudero, 161-180. Sevilla: Escuela de Estudios Hispanoaméricanos 2000.

Sayer, Derek. "Everyday forms of State Formation: Some Dissident Remark in “Hegemony.” In Everyday forms of State Formation: Revolution and Negotiation of Rule in Modern Mexico, edited by Gilbert Joseph and Daniel Nugent, 367 - 398. Durham: Duke University Press, 1994.

Schmidt-Nowara, Christopher and John M. Nieto-Phillips, Interpreting Spanish Colonialis. Empire, Nations and Legends. Albuquerque: University of New Mexico Press, 2005.

Seiner Lizárraga, Lizardo. Historia de los sismos en el Perú: catálogo, siglos XVIII-XIX. Lima: Universidad de Lima, 2011.

Seiner Lizárraga, Lizardo. Historia de los sismos en el Perú. Catálogo: Siglos XV - XVII. Lima: Universidad de Lima Fondo Editorial, 2009. 
Siener Lizárraga, Lizardo. Estudios de historia medioambiental: Perú, XVI-XX. Lima: Universidad Ricardo Palma, 2002.

Sellers-Garcia, Sylvia. Distance and Documents at the Spanish Empire's Periphery. Stanford: Stanford University Press, 2014.

Sifuentes, Luis. “Lima y los desastres sísmicos de 1687 y 1746.” Demiurgo, 2 (2004): 111115.

Silgado Ferro, Enrique. "Historia de los sismos más notables ocurridos en el Perú, 15131974,” Boletín del Institutio de Geología y Minería, 3 (1978).

Sjoberg, Gideon. "Disasters and Social Change." In Man and Society in Disaster, edited by George W. Baker and Dwight W. Chapman, 356-384. New York: Basic Books, 1962.

Stoler, Ann Laura, and Frederick Cooper. "Between Metropole and Colony. Rethinking a Research Agenda.” In Tensions of Empire: Colonial Cultures in a Bourgeois World, edited by Ann Laura Stoler and Frederick Cooper, 1-56. Berkeley: University of California Press, 1997.

Sorkin, Alan L. Economic Aspects of Natural Hazards. Lexington: Lexington, 1982.

Suarez, Margarita. Desafíos Transatlánticos. Mercaderes, banqueros y el estado en el Perú virreinal, 1600 - 1700. Lima: Fondo Editorial Pontificia Universidad Católica del Perú, 2001.

TePaske, John and Herbert S. Klein. The royal treasuries of the Spanish Empire in America, vol. 1. Durham: Duke University Press, 1982.

Thompson, I.A.A., and Bartolomé Yun Casalilla (ed.). The Castilian Crisis of the Seventeenth Century. Cambridge: Cambridge University Press, 1994.

Tobriner, Stephen. "Safety and Reconstruction of Noto after the Sicilian Earthquake of 1693 - the eighteenth Century Context.” In Dreadful Visitations: confronting natural 
catastrophe in the age of Enlightenment, edited by Alessa Johns, 49-80. New York: Routledge, 1999.

Toribio Polo, José. Sinopsis de temblores y volcanes del Perú, siglos XVI-XIX (Lima: Librería e Imprenta de San Pedro, 1899.

Valega, José Manuel. El Virreinato del Perú: historia crítica de la época colonial en todos sus aspectos. Lima: Cultura Ecléctica, 1939.

Valenzuela, Jaime. "El Terremoto de 1647: Experiencia apocalíptica y representaciones religiosas en Santiago Colonial.” In Historias Urbanas. Homenaje a Armando de Ramón, edited by Jaime Valenzuela, 27-65. Santiago: Ediciones Universidad Católica de Chile, 2007.

Van Deusen, Nancy. Entre los sagrado y lo mundano. La práctica institucional y cultural del recogimiento en la Lima virreinal. Lima: Instituto Francés de Estudios Andinos, 2007.

Vega, Walter. “Cofradías Limeñas.” In Lima en el siglo XVI, edited by Laura Gutiérrez, 703-752. Lima: PUCP/ IRA, 2005.

Vega, Walter. "Manifestaciones religiosas tempranas: cofradías de negros en Lima. S. XVI”, Historia y Cultura, n² 24 (Lima, 2001): 15-16.

Vinces Vives, Jaime. An Economic History of Spain. Translated by Frances M. López Morillas. Princeton: Princeton University Press, 1969.

Von Wobeser, Gisela. "La Función Social y Económica de las Capellanías de Misas en la Nueva España del siglo XVIII.” In Cofradías, Capellanías y Obras Pías en la América Colonial, edited by Pilar Martínez López-Cano, Gisela Von Wobeser, and Juan Guillermo Muñóz, 119-138. Mexico: Universidad Nacional Autónoma de México, 1998.

Walker, Geoffrey. Spanish Politics and Imperial Trade, 1700 - 1789. Bloomington: Indiana University Press, 1979. 
Walker, Charles. "Shaking the Unstable empire: The Lima, Quito, and Arequipa Earthquakes, 1746, 1783, 1797.” In Dreadful visitations: confronting natural catastrophe in the age of Enlightenment, edited by Alessa Johns, 113-143. New York: Routledge, 1999.

Walker, Charles. "Great Balls of Fire. Premonitions and the Destruction of Lima, 1746." In Aftershocks: Earthquakes and Popular Politics in Latin America, edited by Jürgen Buchenau and Lyman L. Johnson, 18-42. Albuquerque, 2009.

\section{VITA JUDITH MANSILLA}

Born, Lima, Peru

2004

2008

2011, 2014

2012

2012

2014
BA, History, Pontificia Universidad Católica del Peru (PUCP)

MA, History, PUCP

Tinker Research Field Grant

Research Fellowship, Escuela de Estudios

Hispanoamericanos, Seville - Spain

The History Project Research Award, Joint Center for History and Economics, Harvard University

Morris and Anita Broad Research Fellowship, SIPA, FIU 

International University

Teaching Assistant

2011-2015

Florida International University

2006-2008

Pontificia Universidad Católica del Peru

2005-2009

Research Assistant

Pontificia Universidad Católica del Peru

Publications

Judith Mansilla, "Prestigio social, relaciones interpersonales y beneficio economico en la cofradia de Nuestra Señora de Aranzazu de Lima.” In Devocion, Paisanaje e Identidad. Las cofradias y congregaciones de naturales en España y en America (siglos XVI - XIX), edited by Oscar Alvarez Gila, Alberto Angulo Morales and Jon Ander Ramos Martínez, 231 - 249. Bilbao: Universidad del Pais Vasco. Servicio Editorial, 2014.

Judith Mansilla, "Poder y prestigio social en las cofradías de españoles, siglos XVII y XVIII.” In Corporaciones religiosas y Evangelización en Ibero - América. Siglos XVIXVII, edited by Diego Levano and Kelly Montoya, 229-260. Lima, Universidad Nacional Mayor de San Marcos, 2001.

Judith Mansilla, "Mark Thurner. El Nombre del abismo: meditaciones sobre la historia de la historia.” Surandino Monográfico 3, 2 (2013), 93-94.

Judith Mansilla, "Providing Temporal and Spiritual Assistance: Responses to the 1687 Earthquake in Lima.” The Latin Americanist 57, 1 (March, 2013), 107 - 124. 
Judith Mansilla, “Bourboning the Urban: Reform after the 1746 Earthquake of Lima.” Florida Conference of Historians Annals, 21 (June, 2014), 43 - 56.

Judith Mansilla, "La población de Lima y la administración colonial frente al impacto del terremoto de 1687.” Summa Humanitatis 8, 1 (2015), 52 -73.

Judith Mansilla, “Cristina Mazzeo. Gremios mercantiles en las guerras de Independencia. Perú y México en la transición de la Colonia a la República, 1740-1840.” The Atlantic Millenium. An Academic Journal on Atlantic Civilization 13 (2015), 51-53.

Judith Mansilla, “Charles Walker. Colonialismo en ruinas." Revista Andina, 52 (2015), 259-261.

Judith Mansilla, "El gobierno colonial de Lima y su capacidad de manejo de crisis frente al terremoto de 1687: las respuestas del virrey y el cabildo secular." Revista del Instituto Riva-Agüero 1, 1 (2016), 7-28. 